\title{
Barrett Site (41MM382) Assessment, Milam County, Texas
}

\author{
J. Michael Quigg
}

Paul M. Matchen

Charles D. Frederick

Brittney Gregory

Robert A. Ricklis

Follow this and additional works at: https://scholarworks.sfasu.edu/ita

Part of the American Material Culture Commons, Archaeological Anthropology Commons, Environmental Studies Commons, Other American Studies Commons, Other Arts and Humanities Commons, Other History of Art, Architecture, and Archaeology Commons, and the United States History Commons

Tell us how this article helped you.

This Article is brought to you for free and open access by the Center for Regional Heritage Research at SFA ScholarWorks. It has been accepted for inclusion in Index of Texas Archaeology: Open Access Gray Literature from the Lone Star State by an authorized editor of SFA ScholarWorks. For more information, please contact cdsscholarworks@sfasu.edu. 


\section{Barrett Site (41MM382) Assessment, Milam County, Texas \\ Licensing Statement}

This is a work for hire produced for the Texas Department of Transportation (TxDOT), which owns all rights, title, and interest in and to all data and other information developed for this project under its contract with the report producer. The report may be cited and brief passages from this publication may be reproduced without permission provided that credit is given to TXDOT and the firm that produced it. Permission to reprint an entire chapter, section, figures or tables must be obtained in advance from the Supervisor of the Archeological Studies Branch, Environmental Affairs Division, Texas Department of Transportation, 125 East 11th Street, Austin, Texas, 78701 


\section{Barrett Site (41MM382) Assessment, Milam County (CSJ: 0590-05-027), Texas}

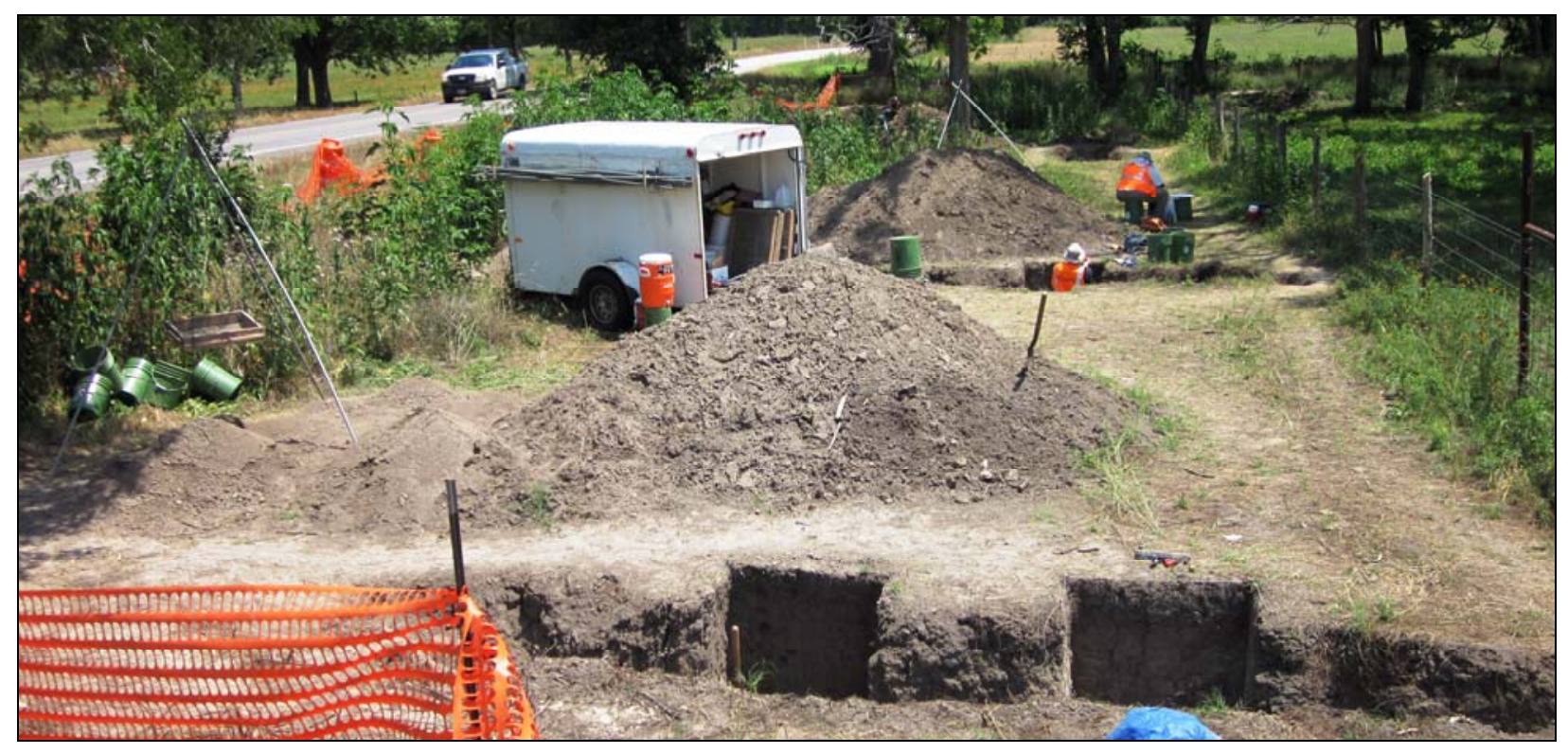

By:

J. Michael Quigg, Paul M. Matchen, Charles D. Frederick, Brittney Gregory, and Robert A. Ricklis

with contributions by

Linda Perry and Trisha-Ann P. Gonzales

Prepared for:

Texas Department of Transportation

Environmental Affairs Division

Archeological Studies Program

Report No. 163

Austin, Texas
Prepared by:

TRC Environmental Corporation

TRC Technical Report

Nos. 192919 and 211462

Austin, Texas

Texas Antiquities Committee Permit No. 6244

Principal Investigator J. Michael Quigg 


\title{
Barrett Site (41MM382) Assessment, Milam County (CSJ: 0590-05-027), Texas
}

\author{
Prepared by: \\ J. Michael Quigg, Paul M. Matchen, Charles D. Frederick, \\ Brittney Gregory, and Robert A. Ricklis \\ with contributions by \\ Linda Perry and Trisha-Ann P. Gonzales
}

Prepared for:

Texas Department of Transportation

Environmental Affairs Division

Archeological Studies Program, Report No. 163

118 East Riverside Drive

Austin, Texas 78704

Prepared by:

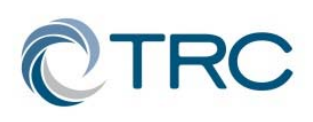

TRC Environmental Corporation

505 East Huntland Drive, Suite 250

Austin, Texas 78752

J. Michael Quigg, Principal Investigator

TRC Technical Report Nos. 192919 and 211462

Texas Antiquities Committee Permit No. 6244

TxDOT Scientific Services Contract Nos. 57-1XXSA003 and 57-3XXSA004

December 2014 
Copyright (C) 2014

Texas Department of Transportation

This is a work for hire produced for the Texas Department of Transportation (TxDOT), which owns all rights, title, and interest in and to all data and other information developed for this project under Contracts 573XXSA004. Brief passages from this publication me be reproduced without permission provided that credit is given to TxDOT and TRC Environmental Corporation. Permission to reprint an entire chapter, section, figures, or tables, must be obtained in advance from the Supervisor of the Archeological Studies Program, Environmental Affairs Division, Texas Department of Transportation, 125 East $11^{\text {th }}$ Street, Austin, Texas 78701. Copies of this publication have been deposited with the Texas State Library in compliance with the State Depository Requirement.

Printed by:

Document Engine

Round Rock, Texas

December 2014

Jointly published by:

Texas Department of Transportation

Environmental Affairs Division

Archeological Studies Program Report No. 163

Scott Pletka, Ph.D., Supervisor

and

TRC Environmental Corporation

Technical Report Nos. 192919 and 211462

Austin, Texas

ISBN 978-1-935545-30-9 


\section{MANAGEMENT SUMMARY}

The Bryan District of Texas Department of Transportation (TxDOT) proposes to replace the existing bridge at the San Gabriel River along a farm-to-market road and expand the width of the existing two-lane roadway in Milam County (CSJ: 0590-05-027). In response to that proposed development, TxDOT staff archeologists from the Archeological Studies Program in Austin reviewed the Texas Historical Commission (THC) Archeological Sites Atlas, a database which contains previously documented cultural resource sites, and conducted an intensive archeological field survey with mechanical trenching along the proposed area of potential effect (APE) in February 2012. During that survey a buried prehistoric site (41MM382), named the Barrett site, was discovered in Backhoe Trench 7 at the northern end of the APE and on the western edge of the existing roadway. The 1.75 meter $(\mathrm{m})$ deep trench revealed multiple levels/zones of cultural material, which included chipped stone debitage and tools, freshwater mussel shells, and burned rocks. These same types of cultural materials were also observed on the disturbed surface in the spoil from the right-of-way fence posts and a recently installed waterline through the length of the site.

Subsequently, TxDOT, through the Environmental Affairs Division, Archeological Studies Program, contracted with TRC Environmental Corporation (TRC) (Scientific Services Contract No. 571XXSA003) to conduct site eligibility assessment to determine if this prehistoric site was eligible for listing on the National Register of Historic Places (NRHP) and designation as a State Antiquities Landmark (SAL). TxDOT issued Work Authorization 57-111SA003 to TRC to conduct the fieldwork, subsequent analysis, report the findings, and make recommendations concerning the site's eligibility for the NRHP and for designation as a SAL.
The TRC fieldwork was conducted in May 2012 under Texas Antiquities Committee Permit No. 6244 issued to J. M. Quigg (Principal Investigator). Site eligibility/assessment investigations, directed by $\mathrm{P}$. M. Matchen (Project Archeologist), consisted of excavation of 4 mechanical trenches (ca. 42 linear meters) plus $11.4 \mathrm{~m}^{3}$ of hand-excavations in 9 test units (1.00-by- $0.5 \mathrm{~m})$ to a depth of roughly $1.6 \mathrm{~m}$ below surface across the APE as defined by TxDOT, plus initial geoarcheological assessment of the deposits in the APE. The excavations yielded a sample of 3,123 artifacts, dominated by lithic debitage ( 49 percent), burned rocks ( 38 percent) and fragments of freshwater mussel shells (8 percent), as well as 8 formal chipped stone tools that include 3 diagnostic projectile points. Twelve radiocarbon dates from noncultural materials (humates and Rabdotus shells) indicate that the cultural materials represent a roughly 1,500-year period from about 2500 to 3900 B.P. Culturally, this relates to the general Late Archaic I period within the cultural chronology proposed by Johnson and Goode (1994) and supported by Collins (2004). The vertical distribution of materials in the $1.6 \mathrm{~m}$ thick target zone revealed three primary peaks that likely represent different occupational episodes. The horizontal distribution of multiple material classes indicates unique task areas were in use across the APE at different periods. This supports the conclusion that the peaks represent separate episodes of occupation rather than the operation of some sort of post-abandonment site formation process.

Based on the results of the geoarcheology, the results of the hand-excavations combined with the analyses of materials, it is apparent the cultural deposits within the APE contain a rare opportunity to investigate a site dated to the Late Archaic period in alluvial deposits on the Blackland Prairie. Based on the projected yield, the Barrett site has the potential to contribute to a greater understanding of the 
population movements, paleoenvironment, technology, land use, and a number of other important issues centered on the use of the Blackland Prairie region of Texas. Therefore, TRC recommends the Barrett site (41MM382) eligible for listing on the NRHP under Criterion D and for designation as a SAL.
The following report documents the 2012 eligibility investigations and geoarcheological observations at the Barrett site (41MM382), reports the findings and analyses of the materials, and suggests a research design for data recovery. The final reporting of the assessment of the Barrett site was conducted under Work Authorization 57306SA004 issued by TxDOT in November 2013 (Scientific Services Contract No. 57-3XXSA004). 


\section{TABLE OF CONTENTS}

MANAGEMENT SUMMARY .iii

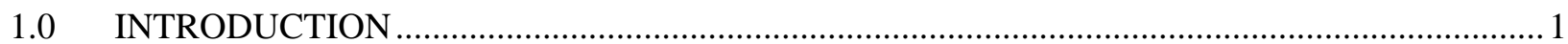

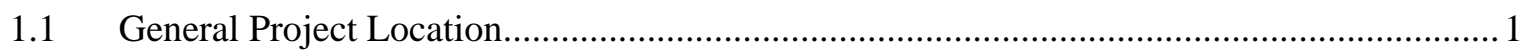

1.2 Texas Department of Transportation Proposed Development ............................................ 4

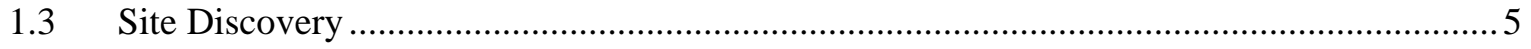

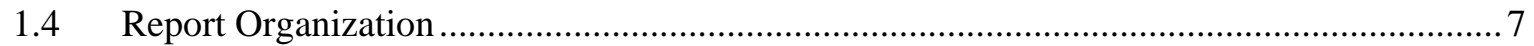

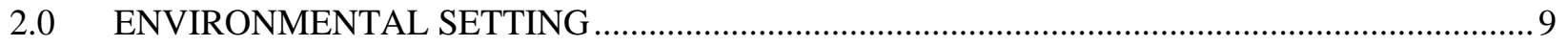



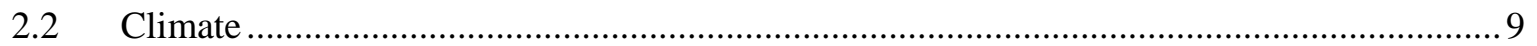

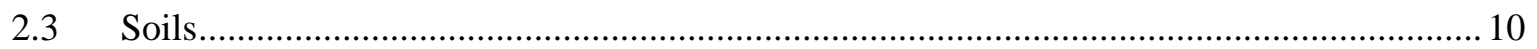

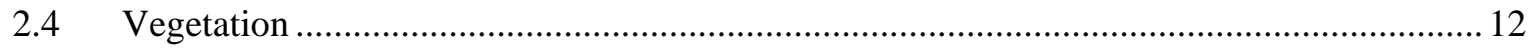

$2.5 \quad$ Fauna

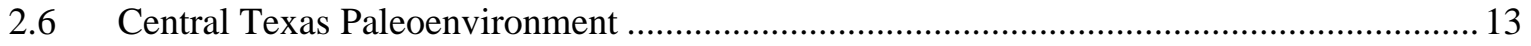

3.0 ARCHEOLOGICAL BACKGROUND AND CULTURAL HISTORY ..................................... 17

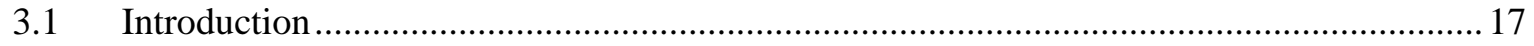

3.2 Previous Archeological Investigations in the Blackland Prairie Region ........................... 17

3.3 The Late Archaic Period (4000 to 1300 B.P.) in Central Texas ......................................... 22

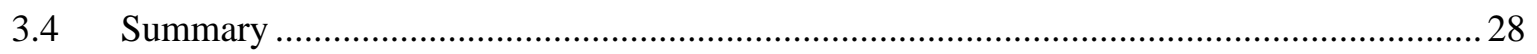

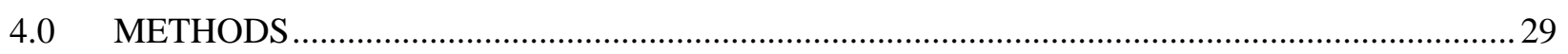

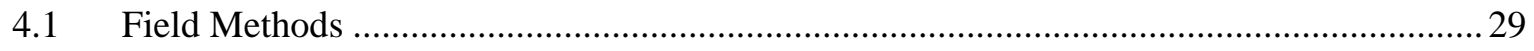

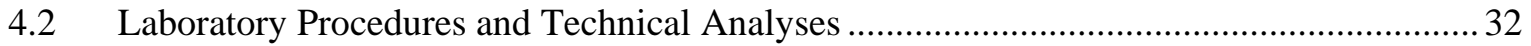

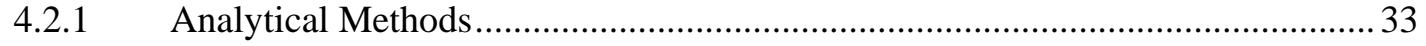

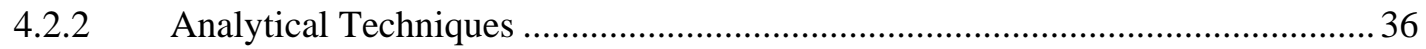

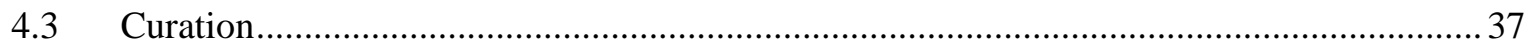

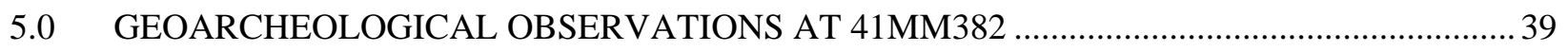

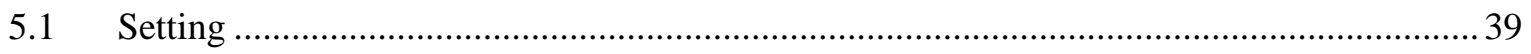

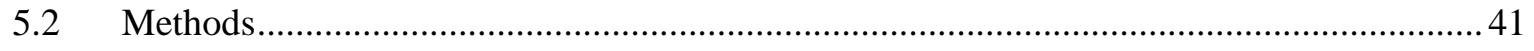

5.2.1 Magnetic Susceptibility …............................................................................ 41

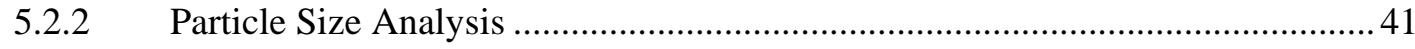

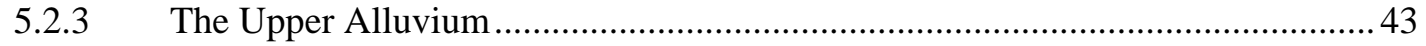

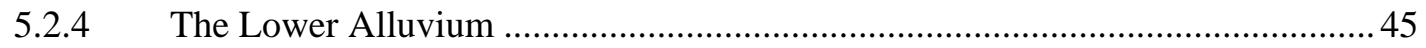




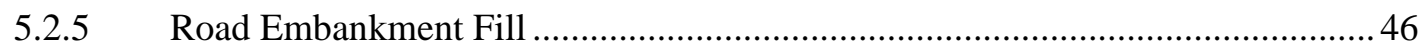

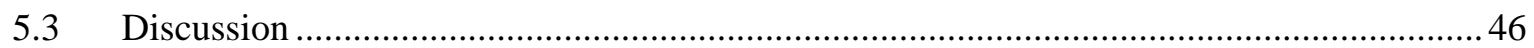

5.3.1 Context of the Cultural Deposits ........................................................................ 48

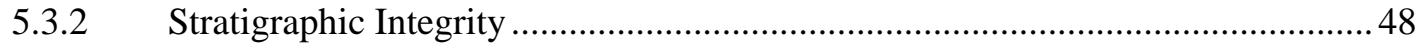

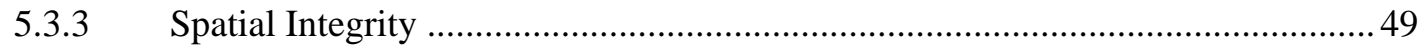

5.3.4 Perishable Material Preservation Integrity......................................................... 49

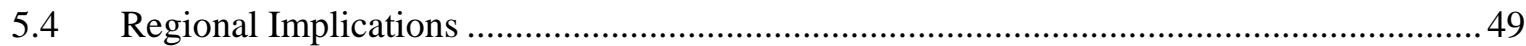

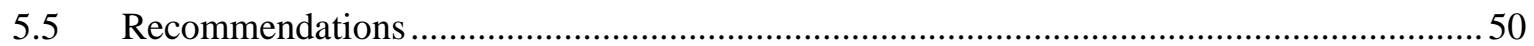

5.5.1 Establishment of Alluvial Architecture and Age ..............................................50

5.5.2 Samples for Paleoenvironmental Analyses ....................................................... 50

5.5.3 Understanding Local Lithic Resources ........................................................... 51

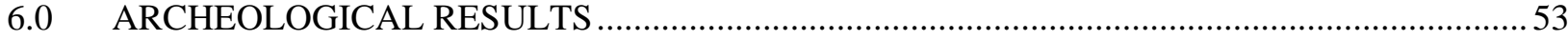

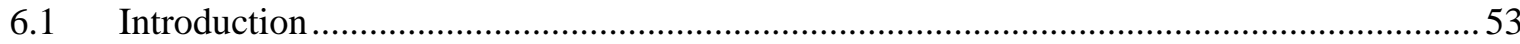

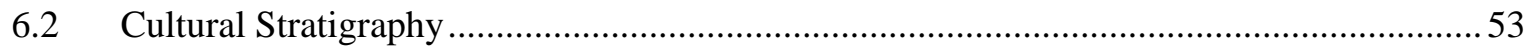

6.2.1 Vertical Distribution by Peaks in Frequency ….................................................. 61

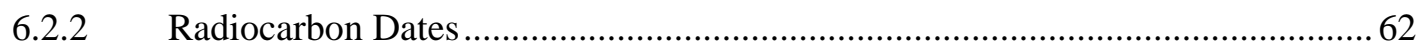

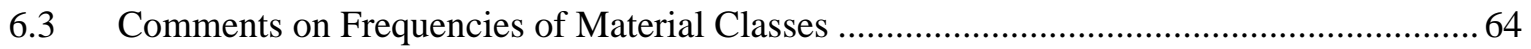

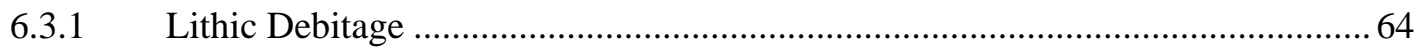

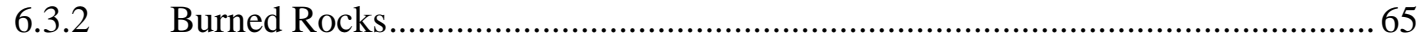

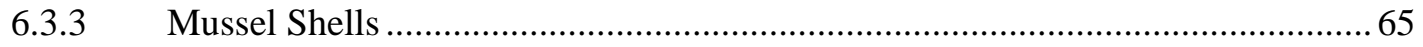

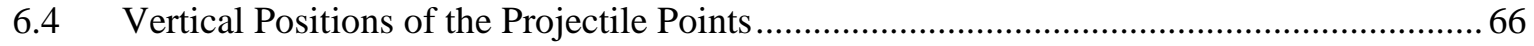

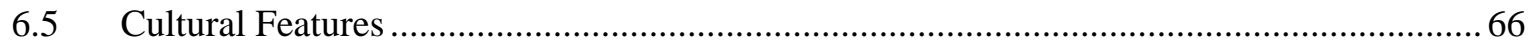

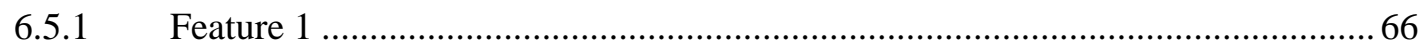

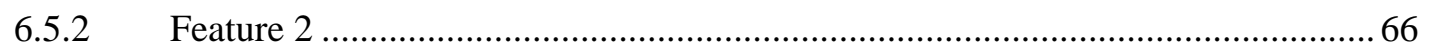

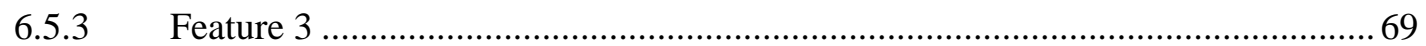

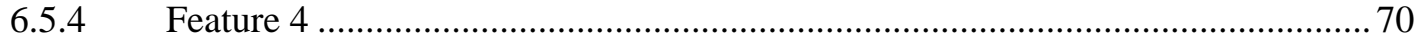

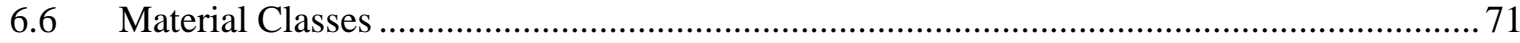

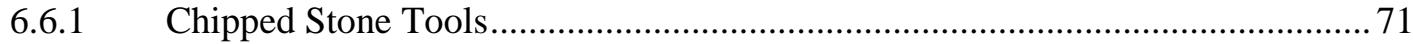

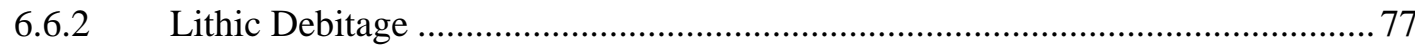

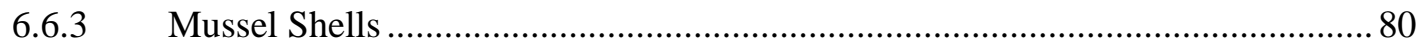

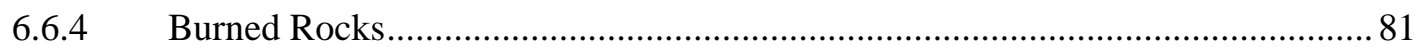

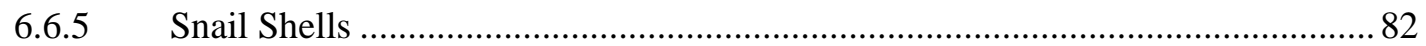

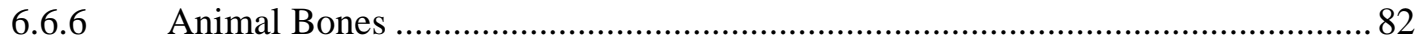




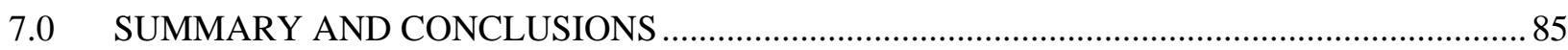

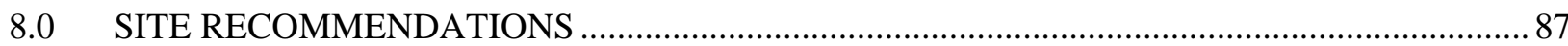

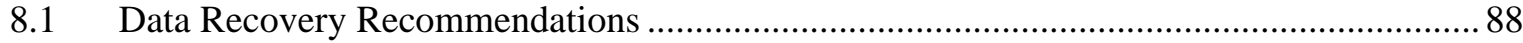

9.0 RESEARCH DESIGN FOR DATA RECOVERY AT THE BARRETT SITE (41MM382) .................. 89

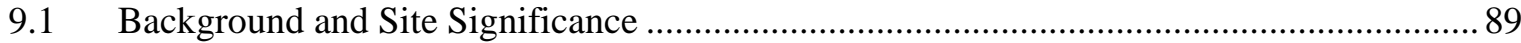

9.2 The Barrett Site and the Nature of Human Occupation of the Blackland Prairie ................ 90

9.2.1. The Question of Prehistoric Cultural Boundaries ................................................. 90

9.2.2. Subsistence Regimes along the Blackland Prairie Zone ..................................... 92

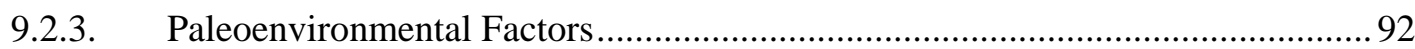

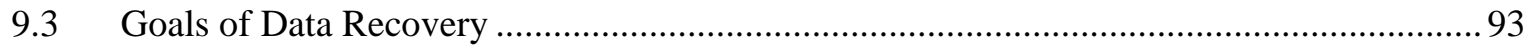

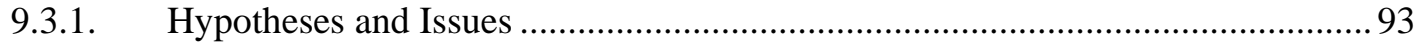

9.4 Key Objectives of Data Acquisition during Data Recovery at 41MM382 …..................... 94

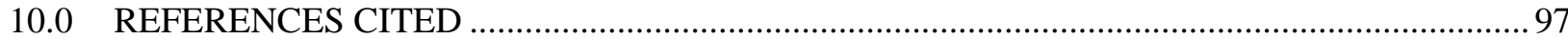

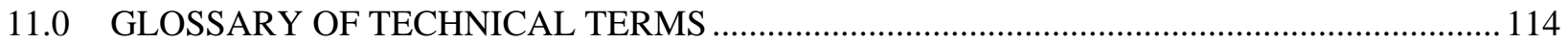




\section{LIST OF APPENDICES}

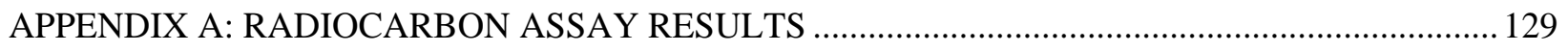

APPENDIX B: STARCH ANALYSIS OF SAMPLES FROM 41MM382 …..................................... 149

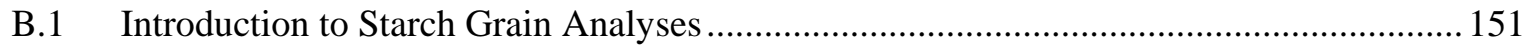

B.2 Understanding the Relationship between Residues and Artifacts ..................................... 153

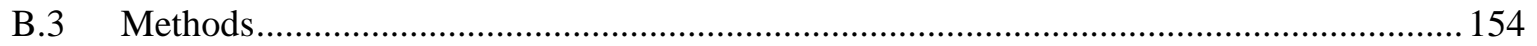

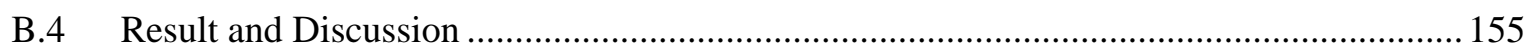

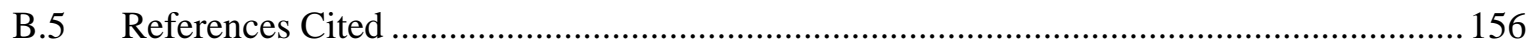

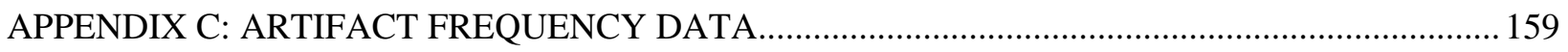

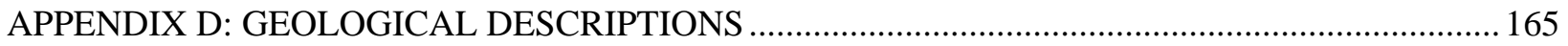




\section{LIST OF FIGURES}

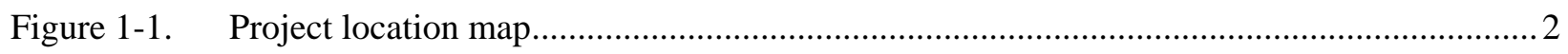

Figure 1-2. Project topographic setting with the Barrett site plotted................................................. 3

Figure 1-3. Site vegetation prior to evaluation, view north. ..................................................... 4

Figure 1-4. Existing farm-to-market road (left), with Barrett Site right of roadway, view south............5

Figure 1-5. TxDOT archeologist Dr. Jason Barrett pointing to Morrill point at $115 \mathrm{cmbs}$ in . profile of TxDOT BT 7 (picture courtesy of TxDOT) .................................................... 6

Figure 2-1. Regional average precipitation for Milam County, Texas. .............................................. 10

Figure 2-2. Regional average temperature for Milam County, Texas. ................................................ 10

Figure 2-3. Soil types in vicinity of Barrett site and APE provided by TxDOT. ................................ 11

Figure 2-4. Comparison of multiple interpretations of changing environments in central

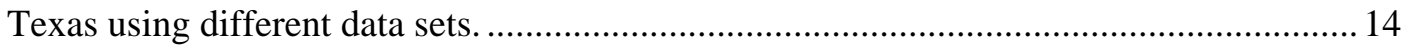

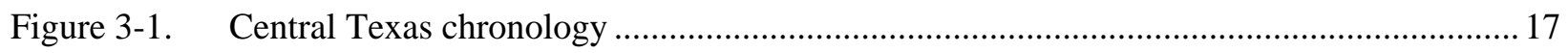

Figure 3-2. Comparisons of the old (Prewitt 1981) and new central Texas chronologies

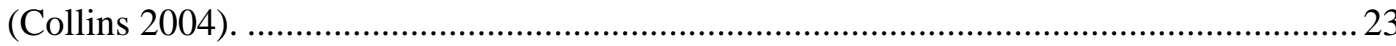

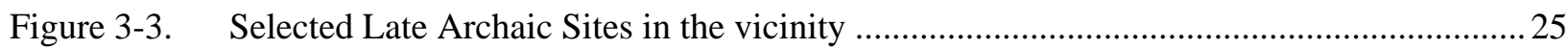

Figure 3-4. Schematic illustration of interpretations of intensity of burned rock midden

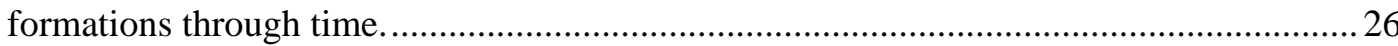

Figure 4-1. Site map showing locations of backhoe trenches and test units within TxDOT ROW....... 30

Figure 4-2. Backhoe trenching at northern end of site boundary. New TxDOT ROW fence

on left and a buried water pipeline below tall weeds on right........................................... 31

Figure 4-3. Hand-excavations along BT 3 at southern end of targeted site....................................... 31

Figure 4-4. Chipped stone artifact analysis flowchart ............................................................... 34

Figure 4-5. Examples of starch grains of wildrye grass recovered from burned rocks at an archeological site (photograph provided by L. Perry).....

Figure 5-1. Geomorphic map of the immediate vicinity of 41MM382 showing the location of the site with respect to the San Gabriel River, and the unnamed tributary that flows adjacent to the northern valley margin....

Figure 5-2. General grab sample of upland gravels depicting size, shapes, and types of available rocks.

Figure 5-3. Upper Panel: Schematic profile of the San Gabriel River Valley parallel to Highway, showing the location of the modern streams and the two paleochannels. Lower Panel: Comparison of the stratigraphy revealed by each trench organized in order from south (left) to north (right).

Figure 5-4. Plot showing the results of lab work on the deposits in Trench 1 and TxDOT Trench 7.

Figure 5-5. Drawing of the deposits exposed on the west wall of TRC Trench 3 _........................... 45

Figure 5-6. Drawing of the deposits exposed on the east wall of TxDOT Trench 7 ..........................45

Figure 5-7. Upper Panel: Plot of the radiocarbon ages by depth and superimposed with lines showing the estimated sedimentation rates. Lower Panel: Bivariate chart showing the calculated sedimentation rate plotted against depth below surface for several central Texas alluvial archeological sites.. 
Figure 6-1. Profile of west wall of Test Unit 9 showing two dense zones of occupational debris, one at ca. $112 \mathrm{cmbs}$ and another at $130 \mathrm{cmbs}$ of TxDOT Trench 7.......................54

Figure 6-2. Barrett site showing distribution of backhoe trenches and test units ...............................55

Figure 6-3. Vertical distribution of three classes of material from Test Unit 1 off Trench 1................56

Figure 6-4. Vertical distribution of three classes of material from Test Unit 5 off Trench 1...............56

Figure 6-5. Vertical distribution of three classes of material from Test Unit 2 off BT 1..................57

Figure 6-6. Vertical distribution of three classes of material from Test Unit 6 off BT 1 .....................57

Figure 6-7. Vertical distribution of three classes of material from Test Unit 3 off BT 3....................58

Figure 6-8. Vertical distribution of three classes of material from Test Unit 7 off BT 3..................58

Figure 6-9. Vertical distribution of three classes of material from Test Unit 8 off BT 3...................59

Figure 6-10. Vertical distribution of three classes of material from Test Unit 4 off BT 3....................59

Figure 6-11. Vertical distribution of three classes of material from Test Unit 9 off TxDOT

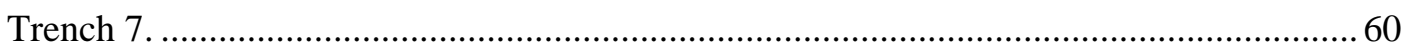

Figure 6-12. Proximal half of Pedernales projectile point (\#70-10) from $70 \mathrm{cmbs}$ in TU 9. .................61

Figure 6-13. Plan view of cluster of cultural materials at ca. $112 \mathrm{cmbs}$ in Test Unit 9,

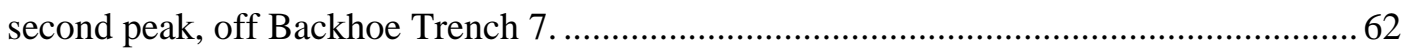

Figure 6-14. Complete Morrill projectile point (\#154-10) from $115 \mathrm{cmbs}$ in TxDOT BT 7. ................. 63

Figure 6-15. Basal section of a possible Morrill projectile point (\#93-10) from 120 to 130 cmbs in TU 9.

Figure 6-16. Plan view photograph of Feature 1, concentration of cultural materials in

Test Unit 3 at $140 \mathrm{cmbs}$ off Backhoe Trench 3.

Figure 6-17. Plan view drawing of Feature 1, concentration of cultural materials in Test Unit 3 at $140 \mathrm{cmbs}$ off Backhoe Trench 3.

Figure 6-18. Plan view photograph of Feature 2, cluster of cultural materials in Test Unit 2, at $140 \mathrm{cmbs}$, off Backhoe Trench 2.

Figure 6-19. Plan view drawing of Feature 2, cluster of cultural materials in Test Unit 2, at $140 \mathrm{cmbs}$, off Backhoe Trench 2.

Figure 6-20. Close-up of Feature 3, a tight cluster of burned rocks in Test Unit 6, at $112 \mathrm{cmbs}$, off Backhoe Trench 2.

Figure 6-21. Plan view drawing of Feature 3, cluster of cultural materials in Test Unit 6, at $112 \mathrm{cmbs}$, off Backhoe Trench 2.

Figure 6-22. Profile of eastern wall of Backhoe Trench 7, revealing Feature 4, a small rock concentration at $110 \mathrm{cmbs}$. .70

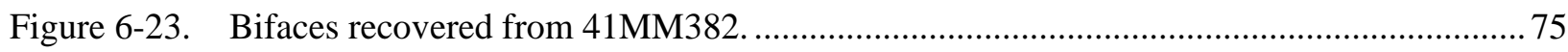

Figure 6-24. Scraper \#37-10 recovered from TU 1, Level 8. Scale in cm.......................................... 76

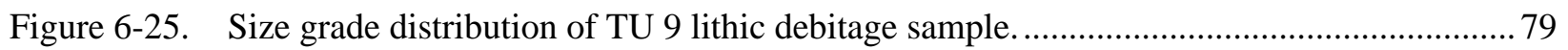

Figure 6-26. Distribution of platform bearing flakes exhibiting thermal alteration ............................. 79

Figure 6-27. Frequency of platform bearing flake types in TU 9 sample debitage assemblage ..............79

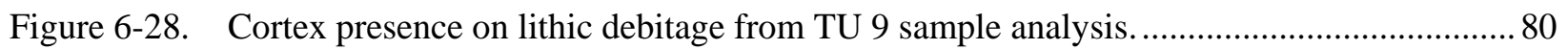

Figure 6-29. Three examples of unwashed burned chert depicting size and angularity ........................ 81

Figure 6-30. Plan view of in situ cluster of small cobbles and large pebbles used as hot rocks at $140 \mathrm{cmbs}$. 82 
Figure 9-1. Chart showing 2-sigma calibrated age ranges of radiocarbon dates from 41MM382, as well as kinds of materials in each date sample.

Figure 9-2. Maps of Texas counties, showing relative abundances of Pedernales and Morrill dart point by county 


\section{LIST OF TABLES}

Table 3-1. Selected Investigated Sites in Williamson County, Texas.............................................. 19

Table 4-1. Data Concerning the Backhoe Trenches at 41MM382................................................ 32

Table 5-1. Results of Analysis of Soil Samples Collected from Trenches 1 and 7.......................... 44

Table 5-2. Range of Probable Sedimentation Rates Within the Strata Bearing Prehistoric

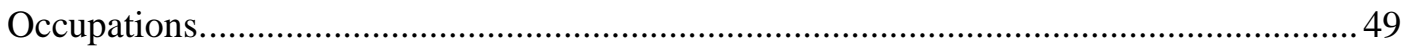

Table 6-1. Pertinent Data Concerning the Radiocarbon Samples and Results.................................... 64

Table 6-2. Artifact Classes and Total Counts by Class for 41M382 ................................................6 65

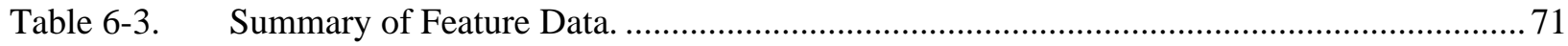

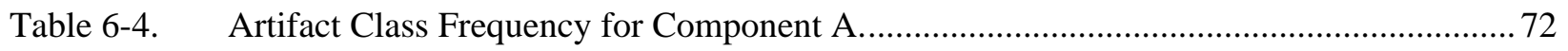

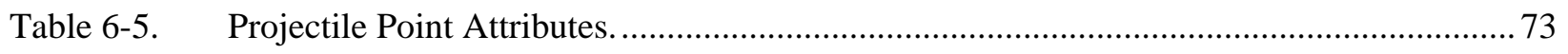

Table 6-6. Selected Attributes on Bifaces from 41MM382 ....................................................... 74

Table 6-7. Selected Scraper and Edge-Modified (EM) Flake Attributes. .......................................... 77

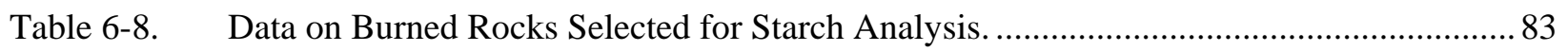

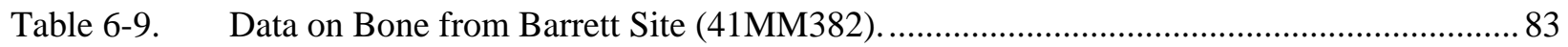

Table B-1. $\quad$ List of Burned Rock Samples Investigated .................................................................. 155

Table C-1. Artifact Frequency Data for Test Units 1 and 2 ....................................................... 161

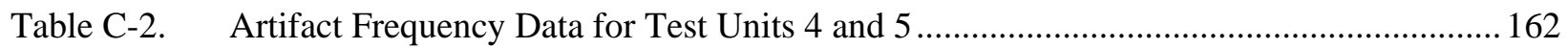

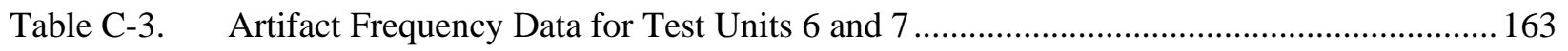

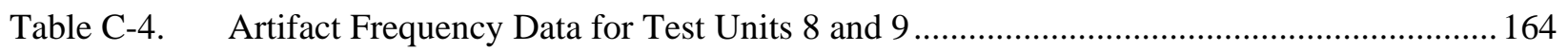

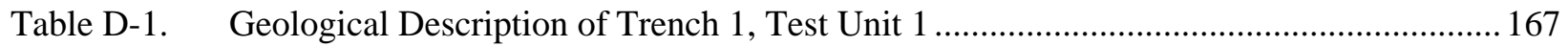

Table D-2. Geological Description of Trench 2, Test Unit 2 ......................................................... 168

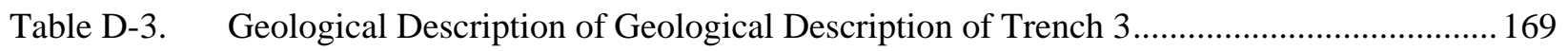

Table D-4. Geological Description of Geological Description of TxDOT Trench 7 ........................ 170 


\section{ACKNOWLEDGEMENTS}

Texas Department of Transportation (TxDOT) staff archeologists, Dr. Jason Barrett and Chris Ringstaff, conducted the initial archeological survey and trenching along the proposed development corridor and discovered site 41MM382 in early 2012. Following their discoveries, they made a recommendation for further investigations to the Texas Historical Commission (THC) as site 41MM382 had potential to contain significant data important to Texas prehistory. The THC determined the site should undergo National Register of Historic Places (NRHP) eligibility assessment and State Antiquities Landmark (SAL) status determination. Subsequently, TxDOT contracted with TRC Environmental Corporation (TRC) under General Service Contract No. 57-1XXSA003 to conduct the necessary assessment of 41MM382. Jason Barrett worked with TRC personnel to facilitate the necessary Work Authorization to allow for the assessment of this site. Jason also provided considerable background information, maps (i.e., Figure 2-3), photographs (i.e., Figure 1-5), and data to TRC as the project moved forward through the reporting phase. TxDOT staff archeologist Dr. James Abbott facilitated the approval and submission of the 13 radiocarbon samples submitted by TRC.

An Antiquity Code of Texas permit was completed by Principal Investigator J. Michael Quigg and submitted to TxDOT, then to the THC to conduct the investigations. Coordination of the field activities was done with the aid of Tom Pickering at the Bryan District to initiate the backhoe work and put into place the necessary safety barriers. The TxDOT backhoe was supplied by the Bryan District and operated by district personnel. Thanks for the prompt excavations of the trenches, meeting our needs, and completing the backfilling.

The TRC archeological staff is thanked for their excellent field energy in face of stiff silty clay and the occasional wet sticky clay. The field crew of Trisha-Ann Gonzales, Shannon Gray, Travis Karlgaard, and Heath Bentley performed admirably under the changing conditions with Paul Matchen serving as Project Archeologist and Field Director. Thanks to Trisha and Shannon for arranging the living accommodations, transportation, and other organizational tasks to facilitate the smooth field operations.

In the laboratory, Trisha washed and cataloged the artifacts, organized the different data sets, prepared the samples and tables to send for technical analysis. She also conducted the initial recording of the artifacts. Thank you Trisha for your attention to detail and willingness to complete the many different tasks requested of you. Shannon, TRC Laboratory Supervisor, established and proofed the electronic database, and provided quality assessment and control over the field records and materials during the various analyses. Shannon also produced the feature line drawings used. She also completed technical editing tasks of sections and chapters, and helped in many different ways. Thanks to Shannon for your management of the database and creation of tables, plus your illustration and editing skills. Thanks to TRC Ry Blaisdell for producing the site plan map using the total mapping station data. Dr. Robert A. Ricklis contributed his knowledge with the formulation of the direction of future research. He also conducted editing tasks and editorial comments on most sections and contributed sections in many parts of the report. Paul Matchen directed the analysis and documentation of the chipped stone tool artifacts, contributed to multiple report chapters, and performed quality review of the report. Marissa Stewart formatted and produced the interim document, whereas Ashleigh Knapp formatted the draft and final document.

Dr. Charles Frederick directed the geoarcheological investigations and was assisted by Brittney Gregory in the field. The team documented the geomorphology of exposed trench profiles and 
collected column samples for further analysis. After the fieldwork, Charles and Brittney coauthored the geoarcheology chapter in this volume and produced the figures and tables therein.

Dr. Linda Perry, Executive Director of The Foundation for Archaeobotanical Research in Microfossils, conducted the starch grain analysis on the initial suite of samples. I thank Linda for her scientific approach to handling the artifacts, her attention to detail and continuous communication and interest in working with us on diverse and multiple artifact classes.
Mr. Elton Prewitt was kind enough to volunteer his time and expertize on two occasions to view and comment on the three projectile points recovered. I thank Elton for his willingness to provide typology comments to these points and to provide comments concerning sites in the Blackland Prairie.

Thanks to all for helping preserve part of Texas prehistory and contributing to our understanding of the past. Any problems in the presentation or errors in content are the responsibility of the project manager.

Mike Quigg

Project Manager 


\subsection{INTRODUCTION}

\section{J. Michael Quigg}

This report presents the archeological field methods, laboratory procedures, analytical processes, interpretations, recommendations from a National Register of Historic Places (NRHP) eligibility assessment of the Barrett site (41MM382) in Milam County, Texas, followed by a preliminary research design for proposed data recovery. The fieldwork was conducted by TRC Environmental Corporation (TRC) archeologists in May 2012 under contract to the Texas Department of Transportation (TxDOT) through the Environmental Affairs Division, Archeological Studies Program. Our investigation was necessitated by TxDOT archeologists discovery of this buried archeological site in the planned expansion of a right-of-way (ROW) in conjunction with a bridge replacement over the San Gabriel River along a farm-to-market road (CSJ: 0590-05027) in the Bryan District (Figure 1-1). The TRC fieldwork was conducted under Texas Antiquities Committee Permit No. 6244 issued to J. M. Quigg as Principle Investigator.

This project was conducted in accordance with the Programmatic Agreement (PA) between TxDOT, the Federal Highways Administration (FHWA), the Advisory Council on Historic Preservation (ACHP), and the Texas Historical Commission (THC) and under a Memorandum of Understanding (MOU) between TxDOT and the THC, and with Section 106 consultation. The proposed roadwork represents a state sponsored project on public lands with the potential for damaging or destroying cultural resources. Consequently, TxDOT was required to conduct a cultural resource survey to meets its legal responsibilities for the identification, evaluation, and treatment of cultural resource properties under existing federal and state regulations, including Sections 106 and 110 of the National Historic Preservation Act of 1966 (P.L 89665; 80 Stat. 915; 16 USC 470 et seq.); and the
Texas Antiquities Code (Texas Natural Resources Code of 1977 [revised 1987], Title 9 Chapter 191, VACS, Art. 6145-9).

TxDOT issued a Work Authorization (No. 57111SA003) to the Cultural Resources Section of the Planning, Permitting and Licensing Practice of TRC's Austin office under TxDOT Scientific Services Contract No. 57-1XXSA004. This Work Authorization directed TRC to conduct the fieldwork and preliminary analysis, complete an interim report of the findings, make recommendations concerning the NRHP eligibility and designation as a State Antiquities Landmark (SAL), and if necessary prepare an initial research design for the proposed data recovery of the Barrett site. Those tasks were completed with the submission of the assessment report in September 2012 (Quigg et al. 2012). Subsequently, TxDOT issued a second Work Authorization (No. 57306SA004) to TRC in November 2013 to complete the draft and final technical reports for this project under TxDOT Scientific Services Contract No. 573XXSA004. This document is directed towards meeting the goals of the latter work authorization.

\subsection{GENERAL PROJECT LOCATION}

This bridge replacement project lies in central Texas roughly 45 kilometers $(\mathrm{km})$ east of Georgetown in western Milam County at the San Gabriel River crossing (Figures 1-1 and 1-2). The surrounding environment is rural in character with nearly level ground and deep alluvial deposits on either side of the river adjacent to lands in the immediate vicinity (Figure 1-3). Prehistoric site 41MM382, lies some $250 \mathrm{~m}$ north of the San Gabriel River and on the west boundary of the current roadway in a low alluvial terrace $\left(T_{1}\right)$. Upon inspection the site was covered in tall weeds and grasses with a few large elm and pecan trees scattered towards the southern end. It lies within the narrow north-south zone of the Blackland Prairie physiographic region with the Edwards Plateau 


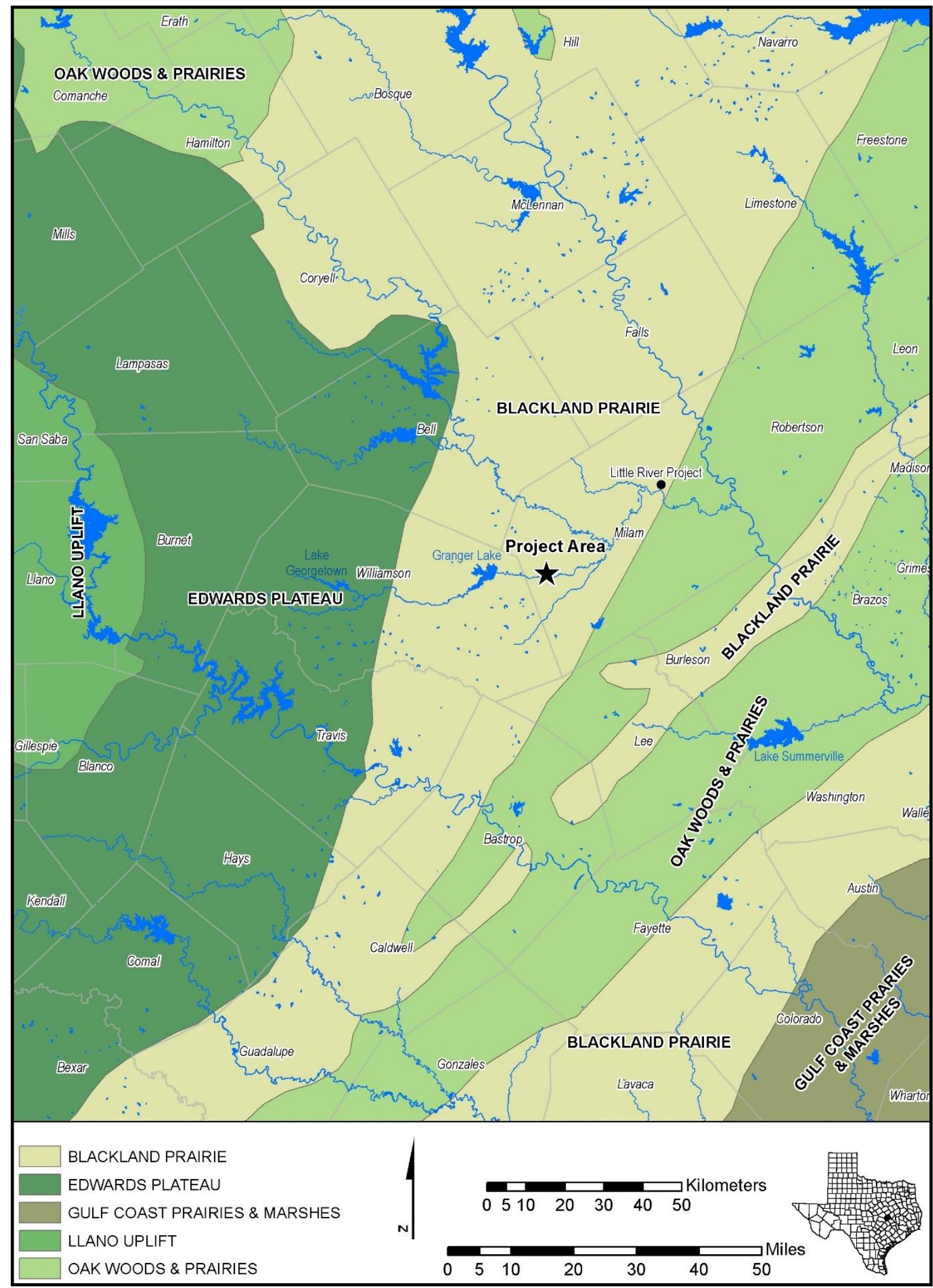

Figure 1-1. Project location map. 


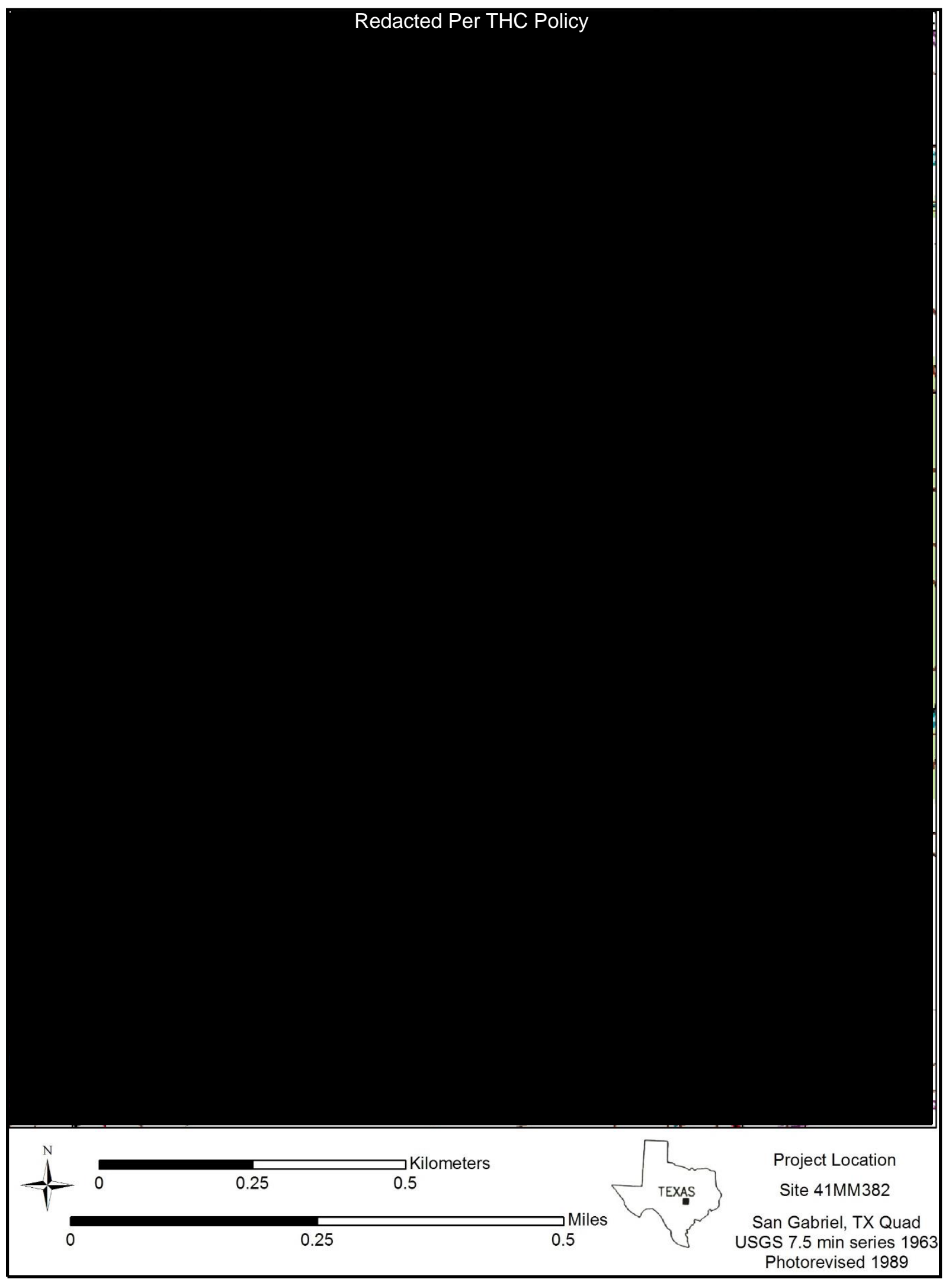

Figure 1-2. Project topographic setting with the Barrett site plotted. 
to the west and the inner Gulf Coastal Plain immediately east.

Modern landscape modifications have occurred at and in the vicinity of 41MM382 and include paved roadway, fencing, and related construction activities on the eastern side, gravel driveways at the northern and southern ends of the defined site, agricultural and pastoral activities adjacent the roadway, the installation of cemented in fence posts into the site, a linear waterline through the middle of the site, utility lines along the existing ROW, and possibly tree removal. The existing farm-to-market roadbed is constructed on a raised fill section. The proposed vertical impacts of the new roadbed are unlikely to extend more than 30 to 60 centimeters $(\mathrm{cm})$, or 1 to 2 feet, below the original ground surface (Figure 1-4). Any impacts associated with construction of the existing roadway are most likely to have been caused by excavation of ditches and would be limited to the margins of the existing ROW.

The gravel driveway that demarcates the northern edge of the area of potential effects (APE) and the archeological site appears to have caused limited subsurface impacts. Plowing is the most common factor of disturbance associated with agricultural activities, but those impacts do not commonly occur deeper than approximately $50 \mathrm{~cm}$ below surface (cmbs). Tree removal would have caused deeper impacts with the potential for disturbing subsurface archeological deposits, but no visible evidence is present that has occurred. Notable disturbances that have directly impacted the archeological deposit include installation of fence posts, some in concrete bases, and a waterline recently installed by Southwestern Milam Water Supply, which currently runs through about the middle of the APE. The spoil from the fence posts and pipeline activities was inspected by TxDOT archeologists and found to contain prehistoric artifacts.

\subsection{TEXAS DEPARTMENT OF TRANSPORTATION PROPOSED DEVELOPMENT}

The Bryan District of TxDOT proposes to replace the existing bridge at the San Gabriel River along the farm-to-market road with a wider two-lane

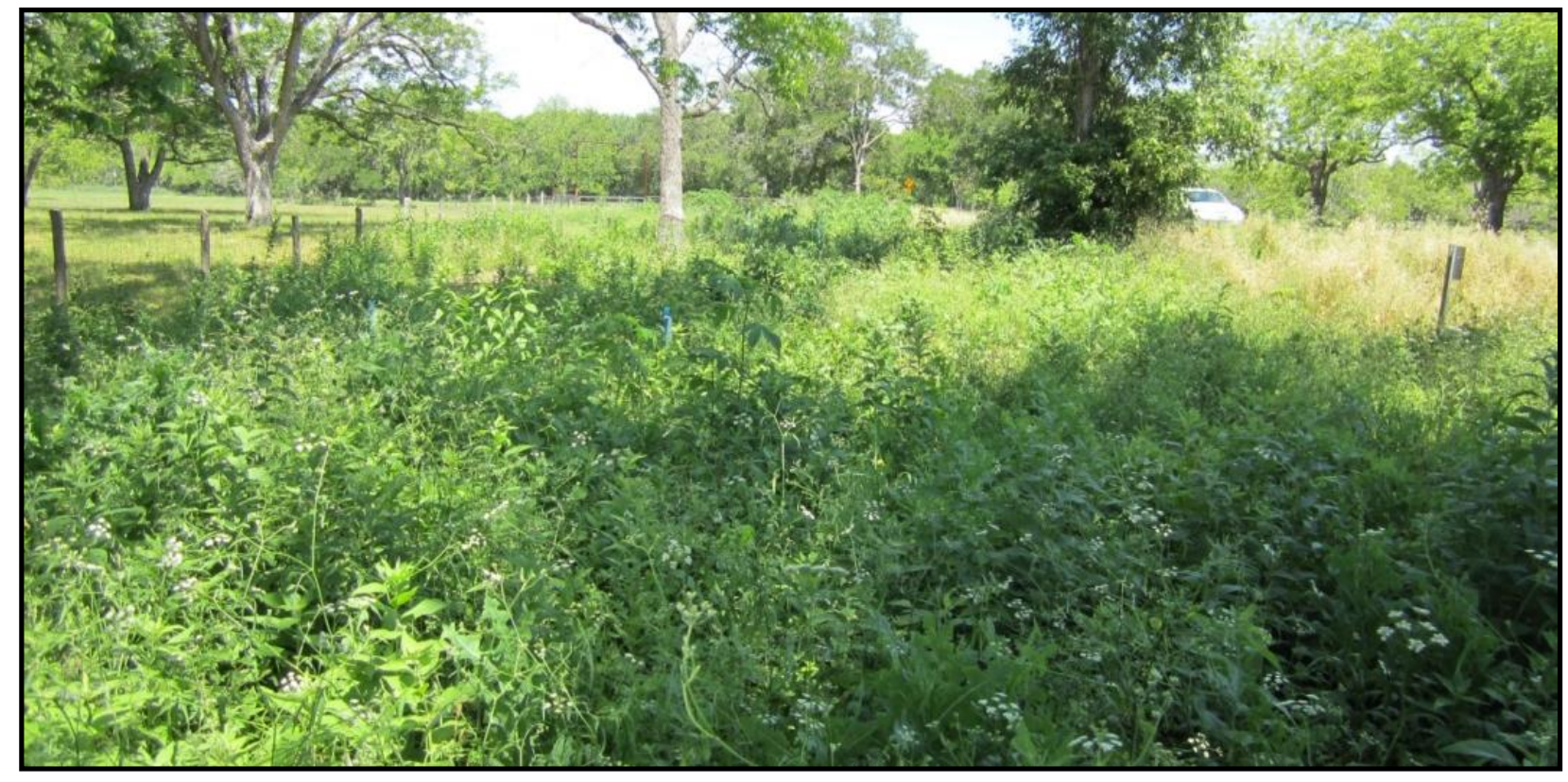

Figure 1-3. Site vegetation prior to evaluation, view north. Note: new ROW fence on left with waterline down through site area, and current roadway on right side. 


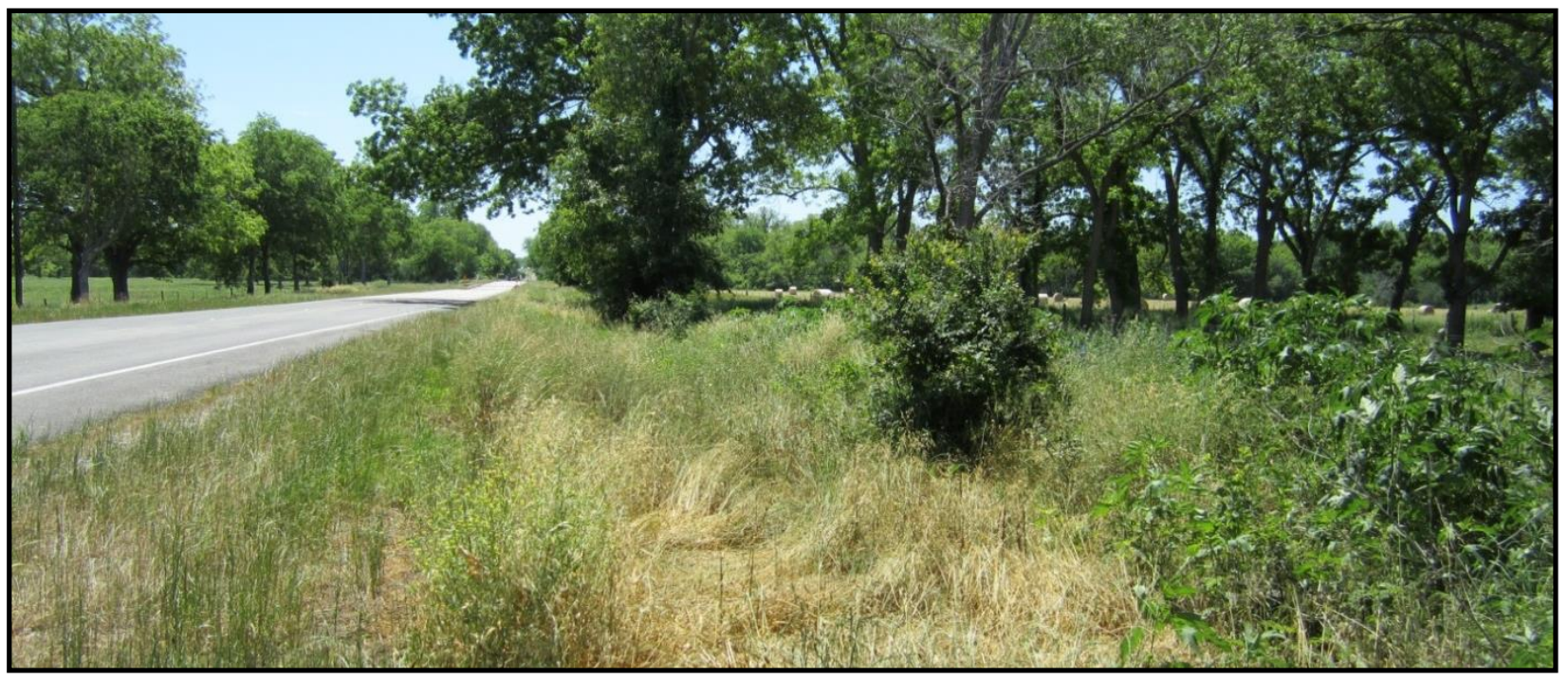

Figure 1-4. Existing farm-to-market road (left), with Barrett Site right of roadway, view south.

bridge that will consist of $3.7 \mathrm{~m}$ (12 ft.) lanes with $3.1 \mathrm{~m}$ (10 ft.) shoulders. The APE encompasses approximately $371.5 \mathrm{~m}(2,400 \mathrm{ft}$.) south of the San Gabriel River to approximately $609.6 \mathrm{~m}$ (2,000 ft.) north of the San Gabriel River, a total of $1.3 \mathrm{~km}$ (0.83 miles). Existing ROW width ranges from 24.4 to $61 \mathrm{~m}$ (80 to $200 \mathrm{ft}$.) and totals some 0.04 square $\mathrm{km}(9.884 \mathrm{ac})$. The proposed ROW is 0.05 square $\mathrm{km}(12.355 \mathrm{ac}$.) with no temporary easements. The new bridge centerline will shift $2.1 \mathrm{~m}(6.6 \mathrm{ft}$.) to the west of the existing centerline. The proposed work will include new bridge approaches, road base, new surface, and replacement of one cross-drainage structure. Depth of impacts at the bridge crossing will be greater than $6.1 \mathrm{~m}$ (20 ft.) for bridge columns and abutments, but quite shallow in other locations.

The proposed project would replace the existing cross-drainage structure with two 1.2- by-1.2 m-by$18 \mathrm{~m}$ long (4-by-4-by-59 ft.) box culverts on its current alignment. The proposed roadway width would be $13.4 \mathrm{~m}$ (44 ft.). Two travel lanes are

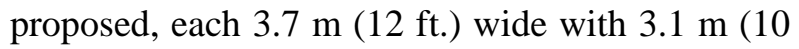
ft.) shoulders.

The APE for the project includes the existing and proposed ROW. The proposed ROW was obtained from along the western edge of the existing ROW.
It includes three tracts of land privately owned by the Dearing's, Bryne's, and Baird's with the largest being the Dearing property. At the time of the investigations, 100 percent of the APE including the Barrett site was owned by the State.

\subsection{SITE DISCOVERY}

TxDOT personnel conducted an archeological site file search using the THC Archeological Sites Atlas (THC Atlas), a database which contains previously documented cultural resource sites that revealed numerous archeological sites along the San Gabriel River (i.e., 41MM19, 41MM20, 41MM2241MM33, 41MM301, and 41MM382). As of February 2011, no historically significant resources had been documented in the APE. The two affected historic age bridges within the APE were determined by TxDOT historians to be not eligible for the National Register during a 1999 survey on nontruss structures.

During TxDOT's intensive archeological survey, a prehistoric archeological site, the Barrett site (41MM382), was discovered by staff archeologists, Dr. Jason Barrett and Christopher Ringstaff, on February 15, 2012. This discovery occurred during a pedestrian inspection combined with mechanical 
trenching along the western side of the APE within the proposed ROW of the farm-to-market road between the San Gabriel River and an unnamed creek channel south of the town of San Gabriel. The total APE of the previous investigation includes 46.7 ha (11.65 ac.) in a long narrow band along the western side of the existing farm-to-market road. Seven trenches were mechanically excavated, three (Trenches 1, 2, and 3) were south of the San Gabriel River and four (Trenches 4 through 7) were north of the river (Jason Barrett, personal communication March 2012). No cultural materials were observed in Trenches 1 through 6. Trench 7 measured $4 \mathrm{~m}$ long by $1 \mathrm{~m}$ wide and $1.75 \mathrm{~m}$ deep, and revealed multiple levels/zones of cultural material, which included chipped stone debitage and tools, mussel shells, and burned rocks. These same types of cultural materials were observed on the disturbed spoil piles from the ROW fence posts and a recently installed waterline through the length of the site. Using the extent of observed surface artifacts, width of proposed and existing ROW, and location of TxDOT Trench 7, TxDOT staff determined this archeological site (41MM382) to be approximately $58 \mathrm{~m}$ north-south by $8 \mathrm{~m}$ east-west, totaling approximately 464 square meters. Cultural materials were observed in all areas of recent disturbance. Within the proposed ROW area west of the existing ROW, this archeological site was delineated on TxDOT schematic plan sheets from Station A of the wooded fence line $(311+65)$ of the southern end to the private driveway $(313+63)$ at the northern end of the APE.

In TxDOT Backhoe Trench 7 (BT 7) cultural materials were observed from $80 \mathrm{cmbs}$ to at least $175 \mathrm{cmbs}$ (Figure 1-5). Burned rocks and mussel shells were frequent throughout the artifact horizon, but not in any discernible concentrations in the trench profile (but the total TxDOT exposure was only 1-by-1.5 m). A cluster of lithic debitage and burned rocks was observed at around $120 \mathrm{cmbs}$. No

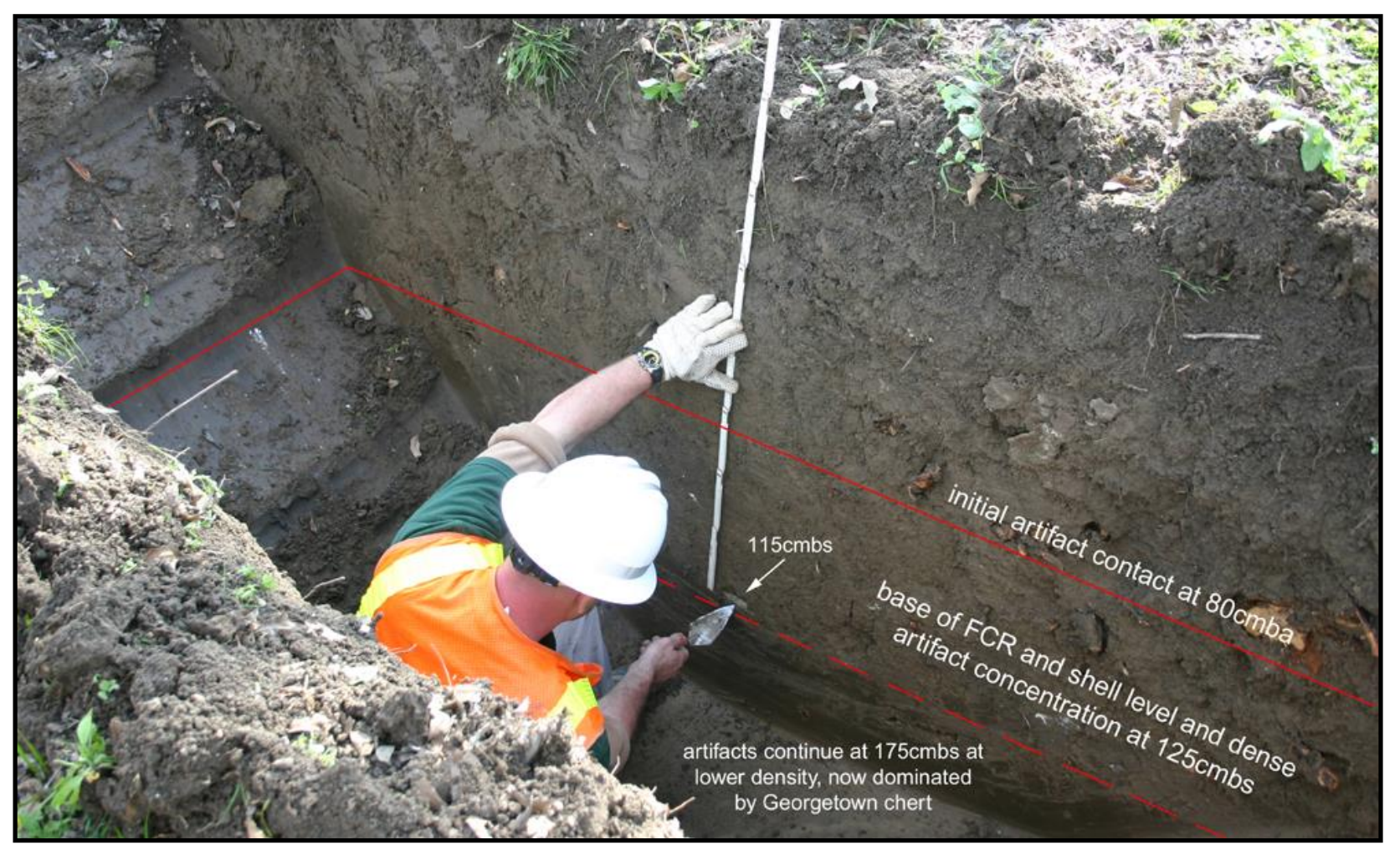

Figure 1-5. TXDOT archeologist Dr. Jason Barrett pointing to Morrill point at $115 \mathrm{cmbs}$ in profile of TxDOT BT 7 (picture courtesy of TxDOT). 
charcoal was identified. The only diagnostic artifact identified was a complete Darl point (now reclassified as a Morrill point) in the trench wall at 115 cmbs. This point was within the identified cultural zone, but debitage was common throughout with pockets of higher density. A strong likelihood exists that the archeological deposit(s) extends beyond its currently defined parameters; outside of TxDOT ROW to the north and west, into existing TxDOT ROW to the east, and into proposed ROW to the south.

\subsection{REPORT ORGANIZATION}

This report is divided into 11 chapters and 4 appendices. Following this introduction, Chapter 2.0 provides an overview of the modern environmental setting for the project area along with a brief review of the current understanding of the regional paleoenvironment. Chapter 3.0 provides an archeological background and cultural history focused on the Late Archaic period for the southern Blackland Prairie region. Chapter 4.0 discusses the field and laboratory methods employed by TRC investigators. Chapter 5.0 is an overview of the geoarcheological information obtained from this testing/evaluation phase. The archeological results are presented in Chapter 6.0. A summary of the findings and conclusions are presented at Chapter 7.0. Chapter 8.0 presents TRC's recommendations concerning the Barrett site's eligibility for listing on the NRHP and designation as a SAL. A proposed preliminary research design for the proposed data recovery phase is presented in Chapter 9.0. This is followed by the references cited in Chapter 10.0. A glossary of technical and unusual terms is provided in Chapter 11.0.

The four appendices provide support data from technical analyses performed following the test/evaluation excavations. Radiocarbon results are provided in Appendix A. This is followed by the starch grain analysis in Appendix B. Appendix C presents the vertical provenience and frequency data of the artifact classes by test unit. Lastly, Appendix D contains geological descriptions of excavated trenches. 
Chapter 1: Introduction

This page intentionally left blank. 


\subsection{ENVIRONMENTAL SETTING}

J. Michael Quigg

\section{$2.1 \quad$ INTRODUCTION}

This section describes the modern environment for the project area in Milam County in east-central Texas (see Figure 1-1). A baseline understanding the modern environment provides clues to why prehistoric peoples occupied this location and what natural resources were in the immediate area and potentially available to the previous occupants. The modern vegetation and soils can and often affect site integrity. The Barrett site (41MM382) sits north of the eastward flowing San Gabriel River, and within the broad San Gabriel Valley itself. The site is $14 \mathrm{~km}$ downriver from Granger Lake and approximately $20 \mathrm{~km}$ southwest of the confluence of the San Gabriel and Little Rivers. The San Gabriel River has its headwaters some $85 \mathrm{~km}$ west in Burnet County, along the eastern margin of the Edwards Plateau. The waters primarily originate from the Edwards Plateau and flow eastward from the Cretaceous limestone before entering the Blackland Prairie, east of Interstate 35. Brushy Creek flows northeastward roughly $6 \mathrm{~km}$ south of the site with the confluence of the San Gabriel River about $14 \mathrm{~km}$ to the northeast. This river system is part of the much larger Brazos River Basin complex that drains southeastward into the Gulf of Mexico.

The Barrett site is underlain by Holocene alluvium that fills the broad San Gabriel River valley, some $1.5 \mathrm{~km}$ wide at this point. The valley bottom is

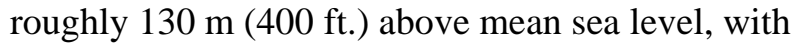
gradually sloping valley walls. South of the site are poorly defined river terraces, labeled Quaternary terrace (Qt) on geological maps (Barnes 1981). Further south are undivided Wills Point and Kincaid formation deposits (Emi) of Eocene age, with clay, silt, and sandy silt deposits, that grades upward to mudstone and sand of the Wilcox Group (Barnes 1981). North of the valley is a narrow band of Upper Cretaceous, undivided Navarro and
Taylor group deposits (Knt), prior to encountering higher Pleistocene gravel terraces (Qhg) present in high areas between creek valleys (Barnes 1981). These gravel deposits are often exposed on the surface and comprised of silty clays and gravels.

The Blackland Prairie is a tall grass prairie that is the southern extension of the True Prairie of the Midwest. It is a western inclusion of the Gulf Coast section of the Coastal Plain Physiographic Province (Fenneman 1938). This is a long, narrow northsouth trending strip just east of the Edwards Plateau and west of the Oak Woodlands. This region is funnel shaped, with the narrowest point near San Antonio, and expanding to the widest segment at the Red River in northern Texas. The western half of Milam County, including the Barrett site, is Blackland Prairie, whereas the eastern half is Oak Woodlands (see Figure 1-1). This western region is a gentle rolling area dissected by many drainages. Elevations across the region range from 91 to 244 m (300 to $800 \mathrm{ft}$.) above mean sea level. Blair (1950) considers this area part of the Texas Biotic Province, an ecotone with interdigitating woodland and prairie, wherein the Blacklands is a major prairie component.

\subsection{CLIMATE}

Milam County climate is humid and subtropical, characterized by hot summers and continental winters (Ramsey 2004). Total annual precipitation is about $86.4 \mathrm{~cm}$ (34 inches). Generally, $45.7 \mathrm{~cm}$ (18 inches), about 52 percent of the annual precipitation, falls from April through September with peak rains of 10 to $13 \mathrm{~cm}$ (4+ inches) in May and September (Figure 2-1). Thunderstorms occur about 40 days each year, most often in May.

Evaporation is high, and rainfall seldom wets the soil below the root zone. Rainfall is sufficient to leach some lime from the upper horizons of many soils, such as Altoga and Sunev soils. Consequently, many of the soils have a layer in which lime has accumulated (Ramsey 2004). 


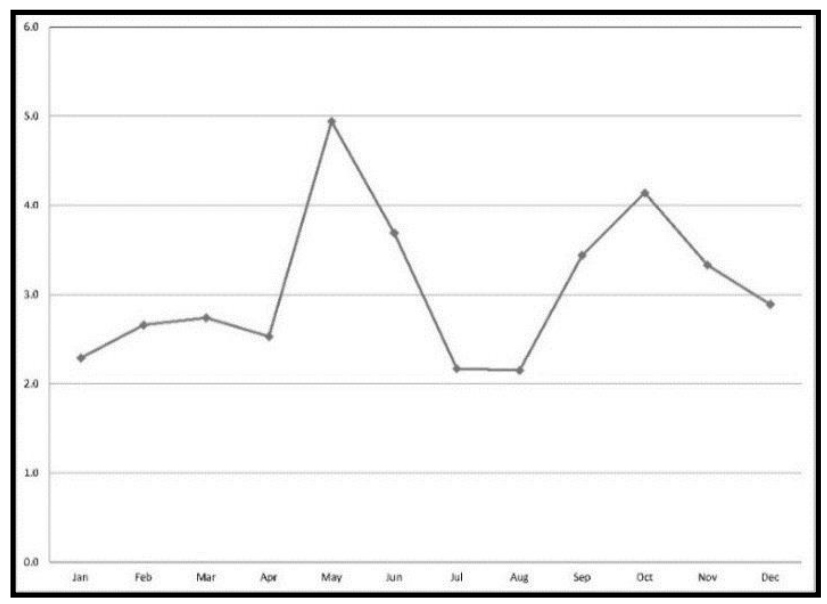

Figure 2-1. Regional average precipitation for Milam County, Texas.

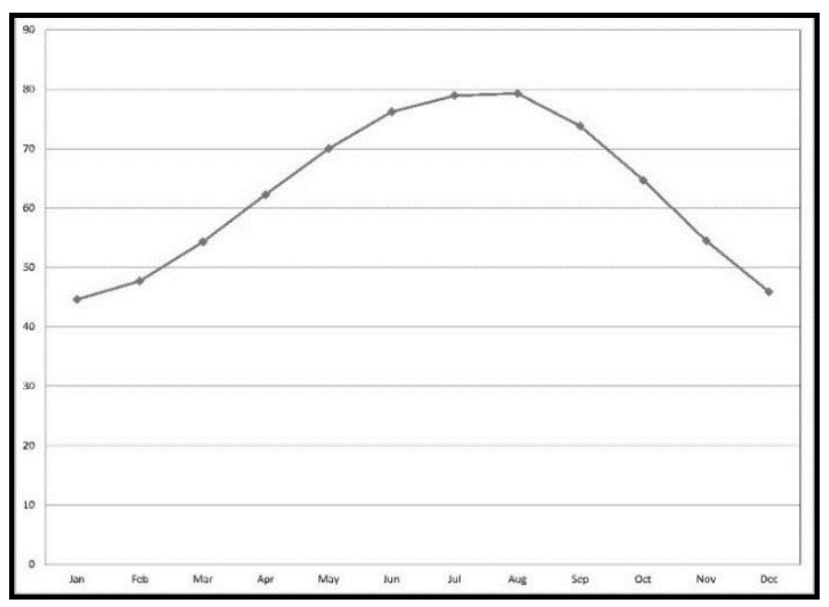

Figure 2-2. Regional average temperature for Milam County, Texas.

In winter, the average temperature is 10.6 degrees Celsius $\left({ }^{\circ} \mathrm{C}\right)$, or 51 degrees Fahrenheit $\left({ }^{\circ} \mathrm{F}\right)$ and the average daily minimum temperature is $4.4^{\circ} \mathrm{C}$ $\left(40^{\circ} \mathrm{F}\right)$ (Figure $\left.2-2\right)$. The lowest temperature on record, $-21.7^{\circ} \mathrm{C}\left(-7^{\circ} \mathrm{F}\right)$ was recorded at Cameron on January 17,1930 . In summer, the average temperature is $28.9^{\circ} \mathrm{C}\left(84^{\circ} \mathrm{F}\right)$. The highest recorded temperature, $45.6^{\circ} \mathrm{C}\left(114^{\circ} \mathrm{F}\right)$, was recorded at Cameron on July 10, 1917 (Ramsey 2004).

\subsection{SOILS}

The site lies within the Frio (Fr) soil series, mollisols formed under grassland conditions, as part of the valley floodplain (Ramsey 2004:99)
(Figure 2-3). The Frio series consist of very deep, well-drained, clayey soils on stream floodplains. These soils form in clayey alluvium and often develop wide cracks when dry. Slopes are mainly less than 1 percent. Frio silty clay, occasionally flooded, typical pedon:

Ap horizon ( 0 to $15.2 \mathrm{~cm}$; 0 to 6 inches) is very dark grayish brown (10YR 3/2) silty clay dry, very dark brown (10YR 2/2) moist; weak fine granular and subangular blocky structure; hard, firm; few fine roots; few fine fragments of snail shells; calcareous; moderately alkaline; diffuse wavy boundary.

$\mathrm{A}_{1}$ horizon (15.2 to $66 \mathrm{~cm}$; 6 to 26 inches) is very dark grayish brown (10YR 3/2) silty clay dry, very dark brown (10YR 2/2) moist; weak fine subangular blocky structure; hard, firm; few fine roots; few fine fragments of snail shells; calcareous; moderately alkaline; diffuse wavy boundary.

$\mathrm{A}_{2}$ horizon (66 to $127 \mathrm{~cm} ; 26$ to 50 inches) is very dark grayish brown (10YR 3/2) silty clay dry, very dark brown (10YR 2/2) moist; weak fine subangular blocky structure; hard, firm; few fine roots; few thin loamy strata; few fine fragments of snail shells; calcareous; moderately alkaline; diffuse wavy boundary.

Bw horizon (127 to 203.2; 50 to 80 inches) is dark grayish brown (10YR 4/2) silty clay dry, very dark grayish brown (10YR 3/2) moist; weak fine subangular blocky structure; hard, firm; few fine roots; few thin loamy strata; few fine fragments of snail shells; calcareous; moderately alkaline.

Other soils in the general area are classified as: Altoga silty clay (AgD2); Branyon clay (Bra); seawillow loam (Smc); Sunev loam (Szc); and Tinn clay $(\mathrm{Tn})$ that is frequently flooded (see Figure 2$3)$.

The depths of the alluvium in which these soils are developed is not consistent, but are suspected to be very deep in areas. For example, the alluvium at Granger Lake varies in thickness from 4.6 to 


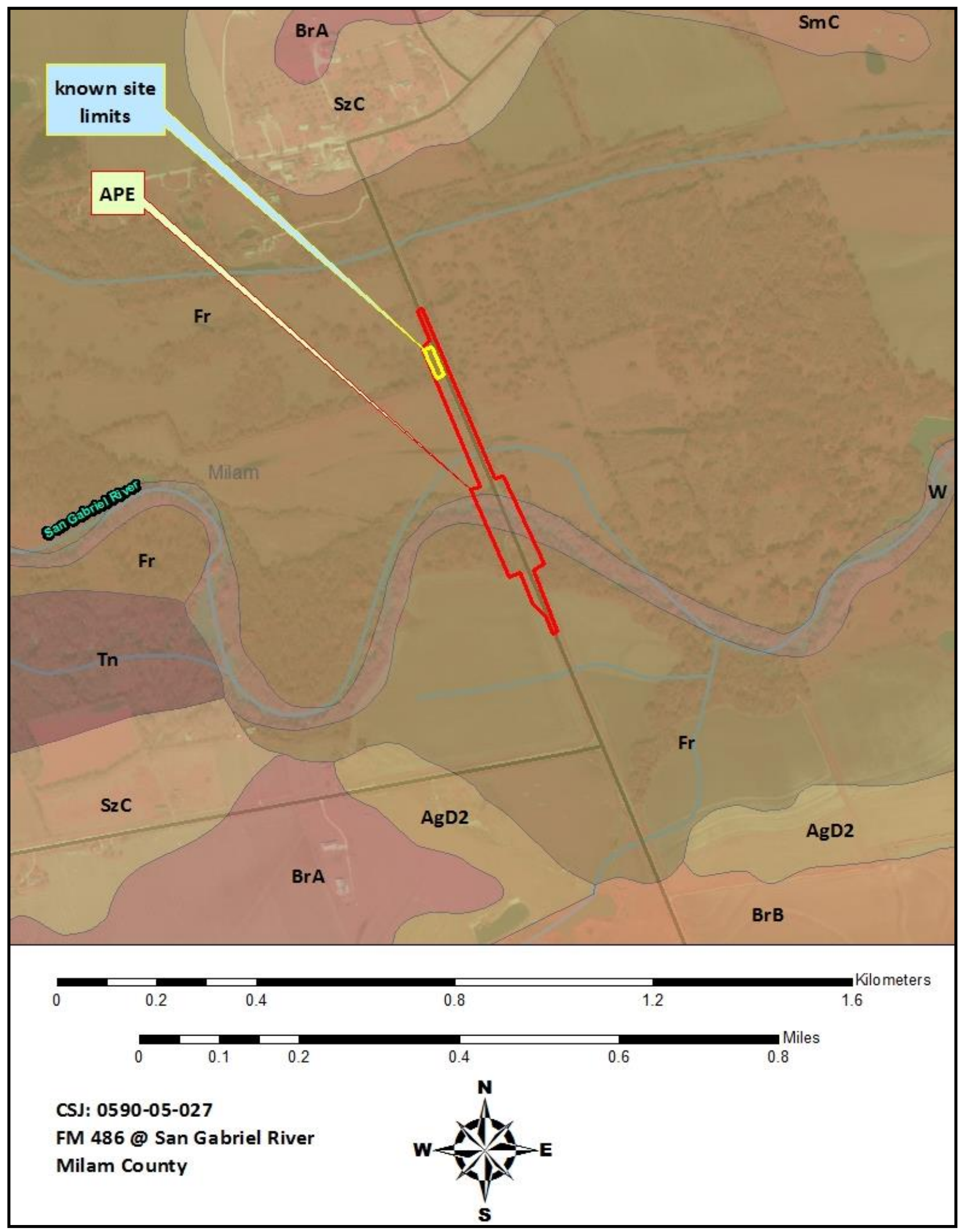

Figure 2-3. Soil types in vicinity of Barrett site and APE (provided by TxDOT). 
$27.5 \mathrm{~m}$ deep (Bond 1978:35). The significant depths provide good context for subsurface stratified cultural deposits of significant time span. Examples of deep alluvium with deeply buried and old occupations are seen in Blackland Prairie settings, such as the aforementioned Granger Lake (Hays 1982), and others such as the Onion Creek valley (Figueroa et al. 2011; Karbula et al. 2011).

\subsection{VEGETATION}

Tharp (1939) designates this area as an extension of the bluestems-(Andropogon)-Stipa-three-awns (Aristida) association of the Tall Grass Prairie. Presently, the bottomlands (floodplains) have been significantly altered from their original state and are comprised of ground-cover regrowth understory (Kenmotsu 1982). These areas are now dominated by introduced species such as brome grasses, rescuegrass (Bromus unioloides) and Japanese brome (Bromus japonicas). Canadian wildrye (Elymus canadensis) and Johnson grass (Sorghum halepense) are found in shaded areas by midsummer, along with scattered populations of Texas Wintergrass (Stipa leucotricha). The overstory includes: netleaf hackberry (Celtis reticulate); ceder elm (Ulmus crassifolia), pecan (Carya sp.), red ash (Fraxinus pensylvanica), red mulberry (Morus rubra), eastern cottonwood (Populus deltoids); prickly ash (Xanthoxylum clava-herculis); deciduous holly (Ilex decidua); black willow (Salix nigra); osage orange (Maclura pomifera); box elder (Acer negundo); soapberry (Sapindus saponaria); and chinaberry (Melia azearach) (Kenmotsu 1982:3-15).

The upland prairie assemblages also reflect disturbed conditions with Johnson grass (Sorghum halepense), Roosevelt weed (Baccharis neglecta), hedge parsley (Torilis arvensis), yellow sweet clover (Melilotus officinalis), and silver-leaf nightshade (Solanum elaeagnifolium). Other major species in the area include prairie three-awn (Aristida oligantha) and little bluestem (Schizachyrium scoparium) (Kenmotsu 1982).
Although most discussions of the Blackland Prairie do not provide potential plant food resources, botanists such as Dering (2000:219) have offered up a number of potential geophyte resources in the Blackland Prairie region that might have been utilized in prehistoric times. These include bulbs of eastern camas (Camassia scilloidies), wild onion and garlic (Allium spp.), false garlic (Nothoscoardum bivalve), rain lily (Cooperia drummondii), dog's tooth violet (Erythronium albidum), yellow-eyed grass (Hypoxis hirsute) along with tubers such as prairie turnips (Psoralea spp.), groundnut (Apios americana), and spring beauty (Claytonia virginica).

Gould (1975) lists a number of forbs found in the Blackland Prairie. These include, but are not limited to, bluebonnet (Lupinus texensis), Mexican hat (Ratibida columnaris), sunflower (Helicanthus annuus), Indian paintbrush (Catilleja indivisa), western ragweed (Ambrosia psilostachya), and milkweed (Asclepias sp.).

\subsection{FAUNA}

As part of the Texan biotic province, Blair (1950:101) lists at least 49 species of mammals are present in this province. Most species are not restricted to this one province. Common species of mammals include: Virginia opossums (Didelphis virginiana); eastern mole (Scalopus aquaticus); fox squirrel (Sciurus niger); Louisiana pocket gopher (Geomys breicepus); western harvest mice (Reitbrodontomys fulvescens); White-footed mice (Peromyscus leucopus); hispid cotton rat (Sigmodon hispidus); eastern cottontail (Sylvilagus floridanus); and swamp rabbit (Sylvilagus aquaticus). Two species of turtles, ornate box turtle (Terrapene ornata) and Florida box turtles (Terrapene Carolina), occur here. Sixteen species of lizards and some 39 species of snakes occur in this province. 


\subsection{CENTRAL TEXAS PALEOENVIRONMENT}

Multiple paleoclimate records are available for interpreting broad periods of paleoenvironment in central Texas, across the Edwards Plateau, the Blackland Prairie, and along its eastern margins in the adjacent Post Oak Savannah region. These diverse datasets include pollen cores from bogs in the Post Oak Savannah (Bousman 1998; Bryant 1977; Holloway et al. 1987; Larson et al. 1972), data from geomorphic investigations of river valleys (Abbott 1994, 2003; Blum 1987; Blum and Valastro 1989; Frederick 2011; Hall 1982a and 1982b, 1990; Johnson 1995; Johnson and Goode 1994; Mear 1998; Nordt 1992, 1993, 2003; Toomey et al. 1993; Waters and Nordt 1995), phytoliths (Bozarth and Woodburn 2011; Cummings 1994; Fredlund 1998), stable isotopes (Frederick 2011; Mauldin 2003, 2006, 2011; Tomka and Mauldin 2003), and cave deposits (Toomey 1993; Toomey et al. 1993), all provide a variety of proxy data for reconstructing paleoenvironment. These proxy data have been summarized several times, and much of the discussion that follows has been extracted from the overviews by Bryant and Holloway (1985), and the more specific trends observed by Bousman (1998).

Bousman (1998), using secondary counts, requantified the pollen results from Boriack and Weakly bogs just east of the Edwards Plateau in the Blackland Prairie. These two bogs provide a 16,000 year sequence of fluctuations between grass and arboreal pollen that indicate shifts between forest, woodland, and open plant communities (Figure 24). Bousman's interpretations of his recalculations indicate that open vegetation communities were present during the Late Glacial Maximum, and between 13,000 and 12,000 B.P., 10,000 and 9000 B.P., and 8000 and 2500 B.P. (see Figure 24). A key factor in understanding these shifts in vegetation is that the mesic woody species invaded grasslands during the moist climates intervals, but woody species died during droughts (Coupland
1958). Data suggests that between 8000 and 7000 B.P. the region became grassland. The phytolith data from the Wilson-Leonard site (41WM235) supports a grassland composition similar to today during the period from ca. 8700 to 6000 B.P. (Fredlund 1998). Along the Texas Gulf Coast, between about 6700 and 6000 B.P., sea level was rising rapidly (Ricklis and Blum 1997). Bousman (1998) indicates a two-phased, midHolocene dry interval occurred, with extremes recorded at 6,500 B.P. and 5,000 B.P. Alternatively, no long-lasting, dry hypsithermal climate was detected by Johnson and Goode (1994) in the eastern Edwards Plateau; consequently, little change occurred in the climate between the Early and Middle Archaic cultural periods. Johnson and Goode (1994) do acknowledge, however, that some climatic drying occurred in late Early Archaic times.

Along Little River in central Milam County, paleoenvironmental reconstruction from roughly between 3000 and 2000 B.P. and the vertebrate faunal analysis indicates mammalian species that preferred riverine/wooded habitats, such as beaver, raccoon, white-tailed deer, and cottontail rabbits, plus reptiles such as turtle. Little River was also home to at least eight species of mussels. Grassland species include jackrabbits and cotton rats. Vertebrate faunal and snails present both indicate the riverine zone was likely bordered by an open grassland environment (Tomka and Mauldin 2003). Plant remains from sites along Little River indicate the past trees included pecan, hickory, honey locust, walnut, oak, willow/cottonwood, elm, holly, box elder, ash, and persimmon (Bush 2006; Dering 2003b).

To the east, geomorphic deposits along the Brazos River reveal the development of the Buffalo soil as the sediment load was reduced from around 4200 to 2500 B.P. (Waters and Nordt 1995). Much of this period is interpreted to be cooler and wetter (Nordt et al. 1994; Waters and Nordt 1995). This general period is projected to have temperatures that 


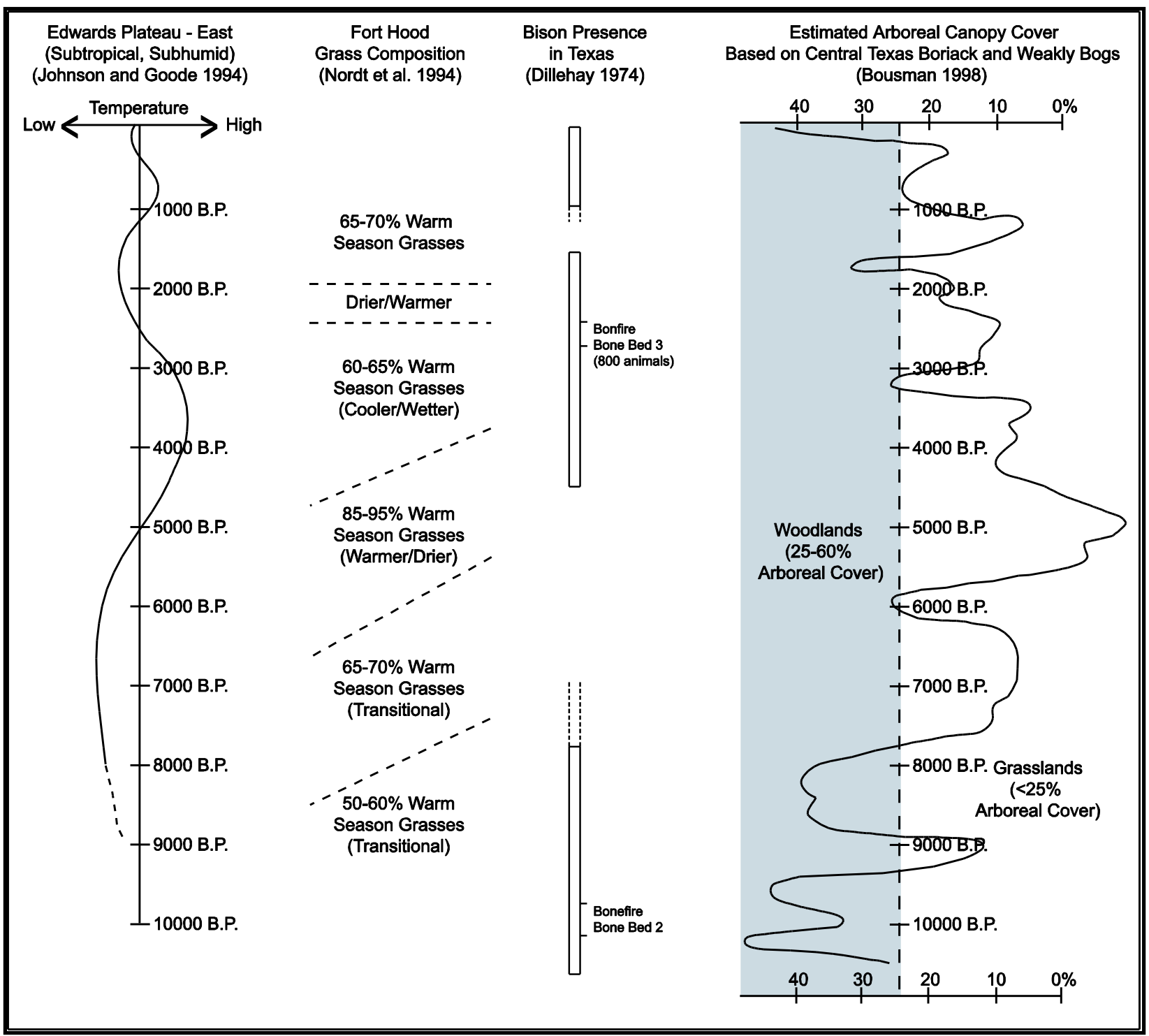

Figure 2-4. Comparison of multiple interpretations of changing environments in central Texas using different data sets.

dropped to slightly below modern July temperatures (Nordt et al. 2007).

West of the Barrett site, near the center part of the Edwards Plateau, the faunal record from Hall's Cave indicates conditions that were dryer than modern from ca. 5000 to 2500 B.P. (Toomey et al. 1993). About the time of this dry interval, the upland soil mantles in central Texas were being rapidly stripped (Toomey et al. 1993), as Nordt (1992) interpreted for the Fort Hood area. Fredlund (1998), using phytolith data from the Edwards
Plateau, sees the overall vegetation composition of central Texas reach its modern balance of woodlands and grassland by about 4000 B.P. Between 4000 and 3200 B.P. was a period of rapid sea level rise (Ricklis and Blum 1997). Johnson and Goode (1994) propose that a dry Edwards Interval lasted from about 5000 to 3000 B.P.

For the last 3000 years of the Weakly Bog sequence, grass and oak pollen are equally represented (Bousman (1998). Starting at roughly 3000 B.P., the pollen frequencies indicate that oak 
woodland was followed by oak-hickory woodland. Bousman (1998) interprets this change to indicate that the climate became progressively moister through the late Holocene. This is in direct contradiction to the interpretation offered by Holloway et al. (1987) on the same bog pollen. Toomey et al. (1993) also see drier conditions culminating between ca. 5000 and 2500 B.P. To date, research has not definitively proven whether flood plain aggradation is related to dry periods or to moist conditions (Johnson and Goode 1994). Toomey et al. (1993) see more mesic conditions from about 2500 to 1000 B.P., with modern conditions predominating from 1000 B.P. to the present. The phytolith assemblage from the WilsonLeonard site indicates that local conditions became less open after 2000 B.P. (Fredlund 1998).

Two significant pollen grass spikes occurred in the Weakly Bog data, one dated to 1500 B.P. and the other estimated at 500 to 400 B.P. (Bousman 1998). These grass spikes are linked to alluvial pedogenesis in floodplain deposits during these periods in Freestone and Leon counties, northeast of the Barrett site. This is significant as grassy intervals have been associated with alluvial stability, but not all researchers agree on this issue. As an outgrowth of his Quaternary work in the upper Sabinal River valley, Mear (1998) believes that down cutting and deposition can occur simultaneously along a stream during both dry and humid climate regimes.

More recently, Frederick (2011), in discussing the late Holocene Unit Qa4 (ca. 3800 to 250 B.P.) from deposits along the lower Onion Creek valley in Austin, roughly $80 \mathrm{~km}$ southwest of the Barrett site, demonstrates a range of about 15 percent variation in the contribution of $\mathrm{C}_{4}$ plants in the stable carbon isotopic record for this time period. This isotopic record reveals more $\mathrm{C}_{4}$ plant input, around $-15.0 \%$, at the beginning and end of the period, with readings around $-18.0 \%$ during the middle portion (Frederick 2011:94). During this depositional period (average rate of $0.166 \mathrm{~cm}$ per year) at least five buried soils are present, which indicate periods of stability within the depositional sequence (Mauldin et al. 2011:98). The phytolith record for this period reveals grass phytoliths dominate the assemblage with Chloridoids (short warm season grasses that prefer relatively warm and dry conditions) accounting for 60 to 95 percent $\mathrm{C}_{4}$ input the most prevalent of the grasses. Late in this period (ca $250 \mathrm{cmbs}$ ) one significant shift/spike is present and shows increased $\mathrm{C}_{3}$ cool season grasses. Overall, the phytolith record contrasts with the stable carbon isotope record (Mauldin et al. 2011:103). Bozarth and Woodburn (2011:220) interpret the temperature as relatively constant through the period with a cooling spike at about 250 cmbs. They also see the aridity index relatively dry until the spike in moisture at about $250 \mathrm{cmbs}$. The snail data from this Qa4 period indicates that our understanding of the habitat conditions preferred by species of snails (i.e., Rabdotus sp., Polygyra texasiana, and Helicina orbiculata) may be far from complete (Mauldin et al. 2011:105).

Caran (1998) provides a cautionary note to interpretation of data used in reconstruction of paleoenvironments, as the data generally represent second, third, or higher-order extrapolations. Along with multiple causes for end effects, this accounts for some of the differing interpretations. Currently, it appears that Johnson's and Goode's (1994) projection of temperature shifts is out of step with Bousman's (1998) canopy cover estimates, and the phytolith assemblage at Morgan Playa (Fredlund et al. 1998) in the Rolling Plains, north of the Edwards Plateau. 
Chapter 2: Environmental Setting

This page intentionally left blank. 


\subsection{ARCHEOLOGICAL BACKGROUND AND CULTURAL HISTORY}

J. Michael Quigg

\subsection{INTRODUCTION}

Excavations at the Barrett site (41MM382) occurred in a Blackland Prairie setting of eastcentral Texas, and revealed multiple cultural occupations within a roughly $1 \mathrm{~m}$ thick zone from roughly 60 to 160 cmbs. These multiple occupations appear to represent a restricted time period. The initial radiocarbon results on bulk sediments and Rabdotus shells from these occupations indicate a general use period of some 1,600 years between ca. 2500 and 4100 B.P. (Prewitt's [1981, 1985] Round Rock phase) and are now assigned to the Late Archaic period of central Texas (Collins 2004) (Figure 3-1). The following

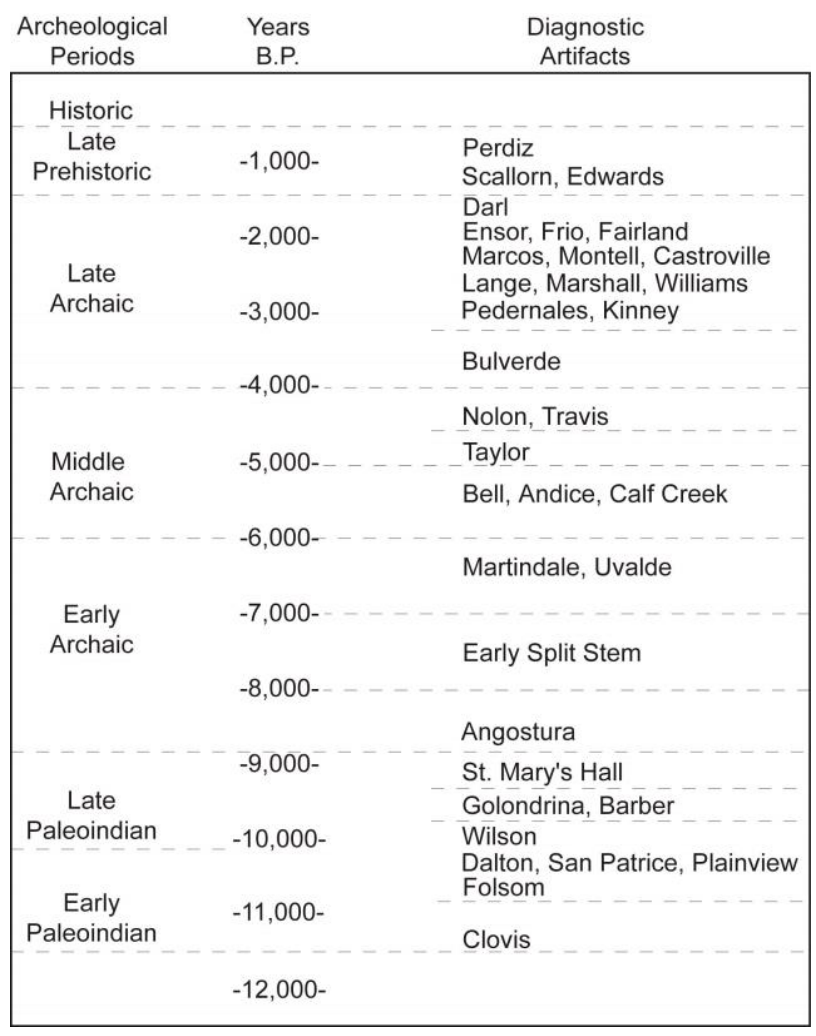

Figure 3-1. Central Texas chronology (adapted from Collins 2004:113, Figure 3.9a). chapter provides a review of selected site excavations in the immediate area, and a general overview of the central Texas Late Archaic as we currently understand it for the southern part of the Blackland Prairie region, south of Waco, with selected examples of investigated sites and data from adjacent regions to help clarify ideas.

\subsection{PREVIOUS ARCHEOLOGICAL INVESTIGATIONS IN THE BLACKLAND PRAIRIE REGION}

Major investigations in Milam County have been few in number, although over 380 cultural resource sites have been documented in the county. The more substantial investigations stemmed from TxDOT road and bridge projects. Surface lignite mines are in the eastern parts of Milam County and multiple surveys have been conducted in them over the years by multiple agencies (e.g., Hageman 1994; LaVardera and Keller 1989). In 2000 eligibility testing was conducted at two sites (41MM340 and 41MM341) in north-central Milam County along Little River (Mahoney and Tomka 2000). As both sites were determined eligible for listing on the National Register of Historic Places (NRHP), both were subjected to data recovery excavations.

Site 41MM341, the J. B. White site, was wellpreserved in deep alluvium and contained multiple stratified components of the Late Prehistoric period. Data recovery excavation focused on broad exposure of a series of occupations dating from 650 to 1150 B.P. (ca. A.D. 800 to 1300) with a more limited samples of a component that dates to roughly 1300 B.P. (ca. A.D. 600 to 700) (Gadus et al. 2006). Excavations consisted of 4 backhoe trenches, 11 initial 1-by-1 m units, and 3 handexcavated blocks covering $208 \mathrm{~m}^{2}$. These yielded a vast array of cultural materials that include considerable stone tools, vertebrate and invertebrate faunal remains, macrobotanical remains, and quantities of burned rocks. These remains represent multiple campsites occupied 
mostly during the summer months by huntergatherers in which mussels, fish, various game animals, mostly deer, nuts, and geophytes (e.g., onions and false garlic) were all part of the subsistence resource (Gadus et al. 2006). This site documents the diversity of resources available in Blackland Prairie and Late Prehistoric populations took advantage of those diverse resources.

Data recovery from $56 \mathrm{~m}^{2}$ in the artifact-dense part of 41MM340 in 2001 and 2002 revealed 15 stratigraphic zones in deep alluvium grouped into seven analytical units that spanned about 1,000 years from 3050 to 2060 B.P. of the Late Archaic period (Mahoney et al. 2003). This site is pertinent to the Barrett site as it is in a similar setting with quantities of mussel shells, and overlaps in time. Twenty-four radiocarbon dates were obtained from 41MM340, 21 of which were from cultural charcoal. The analytical units (AUs) yielded various quantities of burned rocks, lithic debitage, faunal remains, and cultural features. Besides the typical analysis of the cultural materials, special analyses were conducted on Pedernales point style frequencies and distributions, gastropods, Carbon13 and oxygen isotope analyses on mussel shells and Rabdotus, lipid residues on burned rocks, magnetic sediment susceptibility, and data for paleoenvironmental reconstruction. Analytical Units 2, 4, 5, and 6 contributed the most information. Analytical Unit 2 yielded 11 diagnostic projectile points that included 1 Darl, 1 Edgewood, 2 Godley, 1 Kent, 2 Gary and 4 Marcos, whereas AUs 4 and 5 yielded 8 Marcos and 6 Marshal points. Analytical Unit 6 yielded 1 Gary, 1 Marcos, 1 Woden, and 18 Pedernales points (Mahoney et al. 2003). The floodplain dynamics indicate rapid and frequent high-energy overbank flooding and long-term changes in stream flow. Depositional Unit 1, which contained the bulk of the cultural materials, began prior to 4390 B.P. at roughly $9.3 \mathrm{~m}$ below surface and continued to aggrade until near 1270 B.P. (Nordt 2003). Nordt (2003) noted a period of landscape stability and soil formation around 1000 B.P. along Little River and in adjacent river systems that includes the Lampasas and Leon Rivers. The earliest cultural materials at 41MM340 date to around 3000 B.P. at a depth of between 1.5 and $2 \mathrm{~m}$. These cultural deposits were in low-energy flood waters and deposition of clays settling from suspension (Nordt 2003). Multiple research questions were addressed with the recovered data. The site has made significant contributions to the immediate area and surrounding region both in terms of the cultural aspects and the geomorphology.

Many more archeological excavations have occurred in the adjacent Bell and Williamson counties, many in Williamson County along the San Gabriel River and its tributaries, some of which were in the Blackland Prairie as was the major investigations in the Granger Reservoir. Table 3-1 lists some of the more intensively investigated sites in Williamson County. Brownlow (2003) reviews and discusses prehistoric sites along Brushy Creek in the vicinity of $41 \mathrm{WM} 815$ in southeastern Williamson County. Investigations in Bell County have concentrated west of the Blackland Prairie in Fort Hood along the eastern margin of the Edwards Plateau. Just northwest of Milam County, in Bell and Coryell counties, Quigg (1996) provides summaries and interpretations from 119 prehistoric sites investigated between 1993 and 1995 immediately west of the Blackland Prairie at Fort Hood. This includes some 27 prehistoric sites assigned to the Middle Archaic period (4600 to 2250 B.P.) employing Prewitt's chronology (1981, 1985) that now fall within Collins (2004) Late Archaic chronology for the region. Quigg's (1996) summary provides information for comparisons with prehistoric sites in the Blackland Prairie region. A few selected projects and investigated sites in the Blackland Prairie are highlight below to provide a broad understanding of what is known for the Late Archaic period and region, and what has and has not been recovered. 
Table 3-1. Selected Investigated Sites in Williamson County, Texas.

\begin{tabular}{|c|c|c|}
\hline Site No. & Site Name & Reference \\
\hline 41WM2 & Merrell & Campbell 1948 \\
\hline 41WM13 & Bessie Kruze & Johns on 2000 \\
\hline 41WM21 & Centerline & Moore 1978 \\
\hline 41WM40 & $\begin{array}{l}\text { Dobb's Hollow } \\
\text { Canyon }\end{array}$ & Schroeder 2000 \\
\hline 41WM49 & John Ischy & Sorrow 1969 \\
\hline 41WM124 & Bryan-Fox & Peter et al. 1982b \\
\hline 41WM130 & Hoxie Bridge & Bond 1978 \\
\hline 41WM133 & Loeve & Prewitt 1982 \\
\hline 41WM139 & Beaver Head & Clark 1964 \\
\hline 41WM163 & & Peter et al. 1982b \\
\hline 41WM165 & Tombstone Bluff & Prewitt 1982a, \\
\hline 41WM230 & Loeve-Fox & Prewitt 1974, 1982a, 1982b \\
\hline 41WM 235 & Wilson-Leonard & Collins et al. 1998 \\
\hline 41WM258 & Bigon-Kubala & Peter et al. 1982b \\
\hline 41WM267 & Cervenka & Peter et al. 1982b \\
\hline 41WM284 & & Bond 1978 \\
\hline 41WM294 & & Bond 1978 \\
\hline 41WM437 & Rowe Valley & Prewitt 2012 \\
\hline 41WM632 & Blockhouse Creek & Keetley et al. 1999 \\
\hline 41WM815 & Rice's Crossing & Brownlow 2003 \\
\hline 41WM1010 & Shephard & Dixon and Rodgers 2006 \\
\hline 41WM1126 & Siren & Carpenter and Houk 2013 \\
\hline
\end{tabular}

One of the largest and the most extensive projects was the archeological investigations at Granger Lake, an impoundment along the middle San Gabriel River and the subsequent filling of Granger Lake in 1980-81. This United States Army Corps of Engineers (USCOE) project was initiated in 1963 with a reconnaissance survey of the proposed reservoir basin (Shafer and Corbin 1965). Followup testing was conducted beginning in 1968 with three sites being investigated (Eddy 1973). More survey and testing occurred over time until late in 1978 (Patterson and Shafer 1980). At Granger Lake, 10 sites (41WM124, 41WM130, 41WM133, 41WM163, 41WM165, 41WM230, 41WM258, 41WM284, 41WM294, and 41WM267) were intensively excavated and at least 12 others were tested (Bond 1978; Hays 1982; Moore 1978; Prewitt 1982a). Some 24 radiocarbon dates were obtained from Granger Lake sites with 17 from
Loeve-Fox (41WM230) (Prewitt 1982b). Selected sites with direct bearing on the data recovered from the Barrett site are presented.

Testing and data recovery investigations at LoeveFox site (41WM230) yielded significant information that pertains to the Late Archaic period (Prewitt 1974, 1982a, 1982b). The targeted deep alluvium (3.6+ $\mathrm{m})$ revealed a stratified multicomponent site dating back some 3,500 years with high artifact frequencies and features in most occupations. Seventeen radiocarbon dates delineated time ranges for three of Prewitt's 1981 phases (i.e., Twin Sisters, Driftwood, and Austin), which are all less than 2,000 years old. Onehundred and thirty features were identified with cooking features accounting for nearly 79 percent. The site contained a cemetery associated with the Austin phase with skeletons that contained Scallorn points as the probable cause of death; and a human cremation associated with a conch columella bead was recovered from the San Marcos phase component. Some 27 interments and 10 cremations were recognized. Feature and artifact patterning in the Twin Sisters phase revealed a circular encampment composed of smaller activity areas. The Austin phase component is one of the best defined thus far discovered and reported, with six dates, 17 features, plus the cemetery, and some 3,200 artifacts. The Twin Sisters phase represents the most intensive usage with 60 features and nearly 21,000 artifacts (Prewitt 1974, 1982a, 1982b). The horizontal distribution of features and artifacts appeared to represent specific zones of activity and possibly represent small extended family groups. Subsistence activities, specifically in the importance of hunting, appeared to have changed through time (Prewitt 1982a).

For the time period from roughly 4000 to 2600 B.P. (Prewitt's [1981, 1985] Round Rock phase with the diagnostic Pedernales points) very few sites were identified in Granger Reservoir (Peter et al. 1982a). Most occurrences of Pedernales points were isolated finds, or in very poor or mixed context. The 
context of the components from which Pedernales points were recovered also lack radiocarbon dates (Peter et al. 1982a). Relatively few tools and cores were recovered for this time period, although bifaces, retouched flakes, and burins were all present. Occupational intensity for the Round Rock phase was low in Granger Lake, which Peter et al. (1982a:17-9) suggests that this area was not a desired environment at that time. Peter et al. (1982a:17-9) also speculated that the carrying capacity of the Granger Reservoir was not sufficient to support a large population of huntergatherers during the Round Rock phase.

Key pieces of human prehistory extracted from the Granger Lake project, specifically from Hays (1982), are highlighted here. Sites in the San Gabriel River basin were representative of Prewitt's 1976 identified "phases" for central Texas. The 24 radiocarbon dates provided more substantive dates to refining chronology for central Texas. A notable contribution is the radiocarbon sequence and contextual information concerning the Early Archaic occupations. Bulverde and Travis point types were minimally represented of the Clear Fork component at Cervenka (41WM267). Hoxie, Andice, Uvalde, Wells, and Tortugas points all appear before about 5000 B.P. At Cervenka, a Late Archaic San Marcos phase component (Marcos points) was above the Clear Fork component, but no radiocarbon dates were obtained (Peter et al. 1982). Vertebrate and invertebrate faunal remains were collected and identified providing key information towards understanding and addressing subsistence patterns (Fullington and Fullington 1982; Yates 1982). Research was also directed toward understanding the paleoenvironment through macrobotanical (samples were floated), pollen, mollusks, and phytolith analyses. However, samples analyzed for pollen were mostly negative (Hall 1982b), whereas the phytolith results were more positive (Conner 1982).

The siliceous resources (i.e., cherts) in the Granger Reservoir were assessed (Bond 1978:272-283).
These readily available resources were in modern gravel bars, buried gravel bars, and upland terraces. Samples of cherts from four source localities (three upland gravel localities along the San Gabriel River and one from the eastern edge of the Edwards Plateau $4.8 \mathrm{~km}$ [3 miles] west of Georgetown, Texas) formed a study group used in neutron activation analysis (NAA). The cherts in the Hoxie Bridge area have few readily distinguishable characteristics. McGinley's (1978) results indicate that cherts sampled were not homogeneous in elemental concentrations and each sampled locality represented a different rock type (Bond 1978:275). This initial NAA work has inspired continuation of fingerprinting chert resources across the region, which continues to build on human selection of the necessary and valuable chert resources.

Investigations into three sites at the Hoxie Bridge, specifically $41 \mathrm{WM} 130$, indicate that exploitative strategy involved a full range and nonseasonal utilization of nearly all resources contained in the valley environment (Bond 1978). One primary goal was to target the local lithic resources. Raw lithic resources were generally derived from gravel bars. Knapping was focused on cobble reduction into lanceolate shaped bifaces, bifacial reduction of flakes, and the production of blades from cores.

The Bessie Kruze site (41WM13) in the upper 1.5 $\mathrm{m}$ of deep alluvium along Brushy Creek, a tributary to the San Gabriel River, was tested in 1988 and excavated with $42 \mathrm{~m}^{2}$ in 1989. Later Johnson (2000) conducted the analysis and completed the report. Though the Late Archaic deposits encountered were mixed and revealed no natural or clear strata, three zones of cultural debris (Zones I, II, and III from youngest to oldest) were organized, discussed, and supported by 10 radiocarbon dates. Zone I dated to 2310 B.P. on Rabdotus shells and 2280 B.P. on wood charcoal from Feature 7. This most recent zone yielded five rock ovens (Features 3, 4, 5,7 , and 15) and a single scattered fireplace/hearth (Feature 28). A mixture of mostly broken dart and arrow points occurred in Zone I. Zone II yielded at 
least 22 recognizable Pedernales points, 7 rocklined "fireplaces", 5 rock clusters, animal bones, a mussel shell heap (Feature 20), scattered mussel shells, plus a small, mass grave (Feature 13) with comingled parts of at least three human skeletons that date to around 2440 B.P. on wood charcoal from Feature 6. This purposeful grave of secondary interments was covered with white-tailed deer antlers and limestone cobbles. A Pedernales point and probable Pedernales points were in the grave and likely the cause of death. Zone III yielded two human cremations (Features 19 and 21), two rockless fire basins (Features 14 and 17), a cluster of rocks and chert knapping debris (Feature 22), and one Pedernales point. A radiocarbon date on Rabdotus snail shells yielded an age of 4010 B.P., whereas wood charcoal dated to 3020 B.P. (Johnson 2000).

The Shepherd site (41WM1010), in the Blackland Prairie along Brushy Creek and State Highway 130, makes significant contributions to the Driftwood Phase (Darl dart points) of the Late Archaic (1150 to 1350 B.P. or A.D. 600 to 800) and the Austin phase (Scallorn arrow points) of the Late Prehistoric (A.D. 800 to 1200) (Dixon and Rogers 2006). Some 72 cultural features were investigated, 39 which yielded wood charcoal dates between approximately 400 B.C. and A.D. 1200. Forty-one archeobotanical samples were analyzed and 15 yielded carbonized plant remains. These include wood $(43.5 \mathrm{~g})$ from six different plant taxa, four samples contained hickory (Carya sp.) nut shells, and one sample contained an unidentified bulb fragment (Dering 2006). The vertebrate faunal remains $(2,860$ pieces) revealed the presence of mammals (94 percent); reptiles, mostly turtles (5 percent); birds (1 percent); and fish (0.3 percent) (Nash 2006). The mammals include a number that were identified as; bison (Bison bison), white-tailed deer (Odocoileus virginiana), pronghorn (Antilocapra americana), beaver (Castor canadensis), raccoon (Procyon lotor), cottontail rabbit (Sylvilagus sp.), opossum (Didelphis virginiana), hispid cotton rat (Sigmodon hispidus) and pocket gopher (Geomys sp.) (Nash 2006:157). At least one Austin phase feature (D2) dated to 1240 B.P. was occupied in the in winter, late fall, or early spring based on fully formed but unworn $\mathrm{P}_{2}$ and $\mathrm{P}_{3}$ teeth of white-tailed deer (Nash 2006:157). During occupation periods freshwater mussels were also exploited as indicated by some 138 shells or shell fragments, but likely not as the major part of their diets. Mussels include yellow sandshell (Lampsilis teres), smooth pimpleback (Quadrula pustulosa), and tapered pondhorn (Uniomerus declivis) (Marie 2006). The overall results indicate small groups from the transitional Late Archaic (Darl/Driftwood phase) through the Late Prehistoric period (Scallorn/Austin phase) practiced a foraging lifestyle that camped along Brushy Creek and subsisted on diverse resources, although meager evidence of plant use exists. The data indicates little evidence of substantial change in the local environment. Based on relatively large numbers of Late Archaic sites along Brushy Creek, Dixon and Rodgers (2006:19) suggest that this creek served as a territory of several small local groups of hunter-gatherers.

Another Late Archaic site in the floodplain of Brushy Creek, Rice's Crossing (41WM815), also within the Blackland Prairie was investigated in 1999 (Brownlow 2003). From the excavation of 31 $\mathrm{m}^{2}$ in a stratified site, a zone of cultural material was targeted and two occupation surfaces were identified. The upper occupation revealed a $2 \mathrm{~m}$ diameter, $15 \mathrm{~cm}$ deep pit lined with burned rocks thought to be an earth oven (Feature 9). Multiple eastern camas (Camas scilloides) bulb fragments were encountered along with charcoal and multiple Late Archaic dart points (i.e., 2 Castroville, 2 Montell, and 5 Lange) in Feature 9 (Dering 2003a). Eleven radiocarbon dates on charcoal from Feature 9 date from 2240 to 2530 B.P. This feature provides solid evidence that geophytes were targeted, cooked and were part of the prehistoric subsistence base in the riparian corridors of the Blackland 
Prairie. Feature 9 also yielded a small yet diverse faunal assemblage that includes beaver, whitetailed deer, turtle, bird, rodents, pocket gopher, and carnivore (McClure 2003). If all these listed fauna were utilized prehistorically, this again reveals the diversity of the subsistence resources available in the Blackland Prairie.

Another burned rock midden was excavated at the John Ischy site (41WM49) (Sorrow 1969). This site was along the North Fork of the San Gabriel River at the eastern edge of the Balcones Escarpment. This midden revealed probable use over a reported period from about 6000 to 2500 B.P. based on diagnostic projectile points. The identified points include, Bulverde, Castroville, Marshall, Montell, Nolan, Pedernales, and Taylor and Baird triangular darts. A vast array of chipped stone tools were also recovered. However, the vertebrate faunal remains $(N=212)$ were poorly preserved with most revealing eroded surfaces. Species identified (i.e., deer, jackrabbit, canid, turkey, and raccoon) indicate that deer was the primary meat source, whereas no bison bones were identified (Witter 1969:61).

Shafer et al. (1975:8) suggested utilization of the Blackland Prairie during Archaic times was not specialized and intermittent with subsistence patters centered on ecotones along each side of the Blackland Prairie corridor. Subsequently Shafer and Bryant (1976) expanded this idea and envisioned two alternatives: 1) a subsistence pattern that centered on the riparian corridors of the Blackland Prairie and their use for east-west movement to allow utilization of the Edwards Plateau and Post Oak Savannah ecotones; and 2) the original model of two subsistence patterns one centered on the Edwards Plateau using the prairie ecotone and one centered on the Post Oak Savannah using the prairie ecotone. These alternatives have not been thoroughly tested and limited work has been conducted outside the Brushy Creek valley with the exception of the work at Granger Lake.
Although many prehistoric sites have been excavated in Williamson and adjacent counties, many occurred years ago and some lacked broad scale excavations that allow greater interpretations, whereas others lacked the more sophisticated analytical approaches that are now in use. Many even lacked sufficient radiocarbon dates to control the absolute chronology of the multiple occupations encountered, often relying on the diagnostic projectile points for relative dates. Many sites revealed mixed deposits where individual occupations could not be distinguished. Also, most lacked well-preserved vertebrate faunal assemblages and macrobotanical remains to enable discussions of subsistence patterns. Investigated sites often reflected occupations/events less than 2,000 years old. Some sites/components revealed diverse resources used by prehistoric peoples along the San Gabriel River and in the Blackland Prairie.

Even though archeologists have made considerable strides towards understanding the Late Archaic period across parts of Texas, much of that time period and events are still unknown in the Blackland Prairie and need through documentation through more in-depth excavations and diverse analyses. One major area of unknown is the use of plant resources. Although we often refer to the occupants as hunter-gatherers, we still know very little about plants gathered, how plants were processed, and their use. Nuts (i.e., pecans, hickory, acorns, and walnuts), as well as geophytes (e.g., onion, garlic, camas), have all served as food resources, but are there others?

\subsection{THE LATE ARCHAIC PERIOD (4000 TO 1300 B.P.) IN CENTRAL TEXAS}

In central Texas, the Late Archaic is now divided into six intervals based on projectile point types (Collins 2004). Previously, Prewitt's (1976, 1981, 1985) original central Texas chronological sequence, which was used by most archeologists and for most reports up to about A.D. 1995, 
consisted of three phases: Uvalde (Castroville, Marcos, and Montell points), Twin Sisters (Ensor points), and Driftwood (Mahomet [Darl] points). However, that general sequence was modified by Johnson and Goode $(1994,1995)$ and more recently by Collins (2004), which are now in vogue (Figure 3-2). As more sites are excavated and more radiocarbon dates are obtained from good context, the actual timing of cultural events across Texas gradually becomes more secure and better defined (see Carpenter and Houk 2012 for an update on the Late Archaic chronology).

Although the well-stratified Siren site (41WM1126) contributes significant new radiocarbon dates for the end of the Late Archaic, the Transitional Archaic, and into the Late Prehistoric period, as so often occurs the early part of the Late Archaic from ca. 4000 B.P. to 2200 B.P. was not represented at that site. Many archeological sites that represent the latter part of the Late Archaic have been excavated, although few well- stratified components are represented or reported, and even fewer have solid radiocarbon dates associated with robust cultural assemblages (Collins 1995, Table 2; Collins 2004, Figure 3.9a). Johnson and Goode (1994) provide a slightly different view by subdividing this period into early ("Late Archaic I") and late ("Late Archaic II") subperiods. The division is based on perceived changes in the archeological record. In the Late Archaic I, common dart points include Bulverde, Pedernales, Marshall, Montell, and Castroville. Marcos, Ensor, Frio, Darl, and Figueroa are common in Late Archaic II. Johnson and Goode (1994) indicate a time of about 2,500 B.P. for the division of the two subperiods. Although the projectile point sequence has not changed drastically from Prewitt's original work (1981, 1985), Johnson and Goode (1994) placed the Bulverde, Pedernales, and Marshall points of Prewitt's Middle Archaic into their Late Archaic period. Going forward, if absolute dates are not presented, one can be confused if only the general

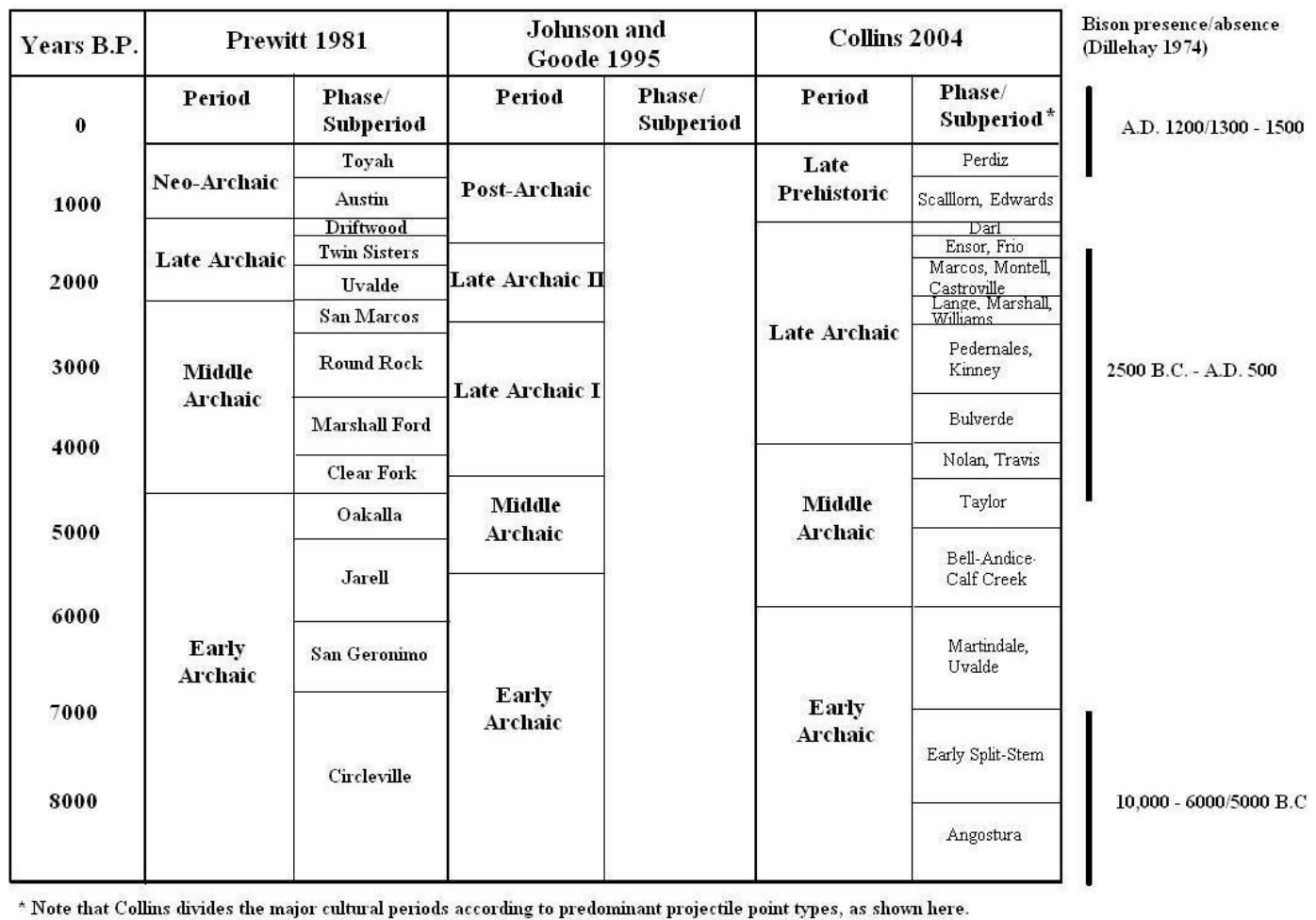

Figure 3-2. Comparisons of the old (Prewitt 1981) and new central Texas chronologies (Collins 2004). 
time period (i.e., Middle or Late Archaic) is referred to, if not referencing the specific point type. The Johnson and Goode (1994) division, with the Marcos type occurring later than the Montell and Castroville is potentially problematic as many researchers consider these points to be about the same age.

Two sites of better context with radiocarbon dates and Uvalde phase projectiles (i.e., Marcos, Montell, and Marshall types) are found at 41GT91 many kilometers northwest of the Barrett site, and Culebra Creek site (41BX126) at the base of the Balcones Escarpment near San Antonio (Figure 33). At 41TG91 (East Levee), Balcones Escarpment near San Antonio (Figure 3-3). At 41TG91 (East Levee), Marcos points are associated with three radiocarbon dates of $2910 \pm 270$ B.P. (Tx-4764B), $2540 \pm 80$ B.P. (Tx-4764A), and $2480 \pm 60$ B.P. (Tx-4761) (Creel 1990). At Culebra Creek, three Montell and one Marshall point came from a thin burned rock midden (Feature 2) associated with two charcoal dates of $2700 \pm 50$ B.P. (NSRL-3520) and $2780 \pm 50$ B.P. (NSRL-3519) (Nickels et al. 2001). These later two sites document the age of these three point types by associated radiocarbon dates and indicate these types can occur as separate entities.

Also at Culebra Creek (41BX126), a rare and distinct Nolan component is present in Area B. Three features (Features 7, 11, and 12) were identified in the component. Feature 7, referred to as an oven yielded two Nolan points. A radiocarbon date on charcoal at the base of the feature was 4940 \pm 50 B.P. (NSRL-3697) with a second charcoal date of $4630 \pm 40$ B.P. (NSRL-3698) from the upper portion (Nickels et al. 2001). Other dart points in the component include one Tortugas, one Langtry, one Nolan-like, and three other Nolan points. Interestingly, fish otoliths were present in Feature 7 and dated, but their dates are all older than the associated charcoal dates.
Pedernales points representative of the Late Archaic do occur in the Blackland Prairie as indicted by sites such as Bessie Kruze (Johnson 2000) and 41MM340 (Mahoney et al. 2003). There are even found further east in the Post Oak Savannah at such sites as Bull Pen (41BP280) (Ensor and Mueller-Wille 1988) and Kennedy Bluffs (41BP19) (Bement 1989) in Bastrop County.

Burned rock middens, thought to have debut in the Middle Archaic period (Black and Creel 1997; Prewitt 1981; Weir 1976), continue through the Late Archaic period (Figure 3-4), some with welldefined central pit features or rock ovens (i.e., Ricklis and Collins 1994; Black et al. 1997; Brownlow 2003; Mauldin et al. 2003). Many researchers believe that rock ovens and large middens represent the cooking of bulk plant resources such as sotol or lechuguilla that require long periods of heating to make consumption possible. An alternate hypothesis based on the broad distribution of oak trees and burned rock middens is that these features were used to process acorns (Creel 1986, 1991, 1997). More recently it has been directly demonstrated by the identification of carbonized plant parts that geophytes (i.e., tubers, bulbs, and roots) were cooked in burned rock ovens and middens (Brownlow 2003; Dering 1997, 1998, 2003a; Mauldin et al. 2003; Mehalchick et al. 2004; Quigg et al. 2011). Cooking of geophytes has occurred in the Blackland Prairie region during the Late Archaic (e.g., 41WM815) (Brownlow 2003) and even in earlier periods such as demonstrated at Armstrong (41CW54) (Dering2002; Schroeder and Oksanen 2002), and Berdoll (41TV2125) (Karbula et al. 2011). Chemical residue analysis on burned rocks from a large central cooking feature in a burned rock midden at Mustang Branch midden (41HY209) revealed animal residues present (Loy 1994). Other smaller burned rock dumps, scatters, basins, and flat hearths have been recognized at various sites during the Late Archaic. 


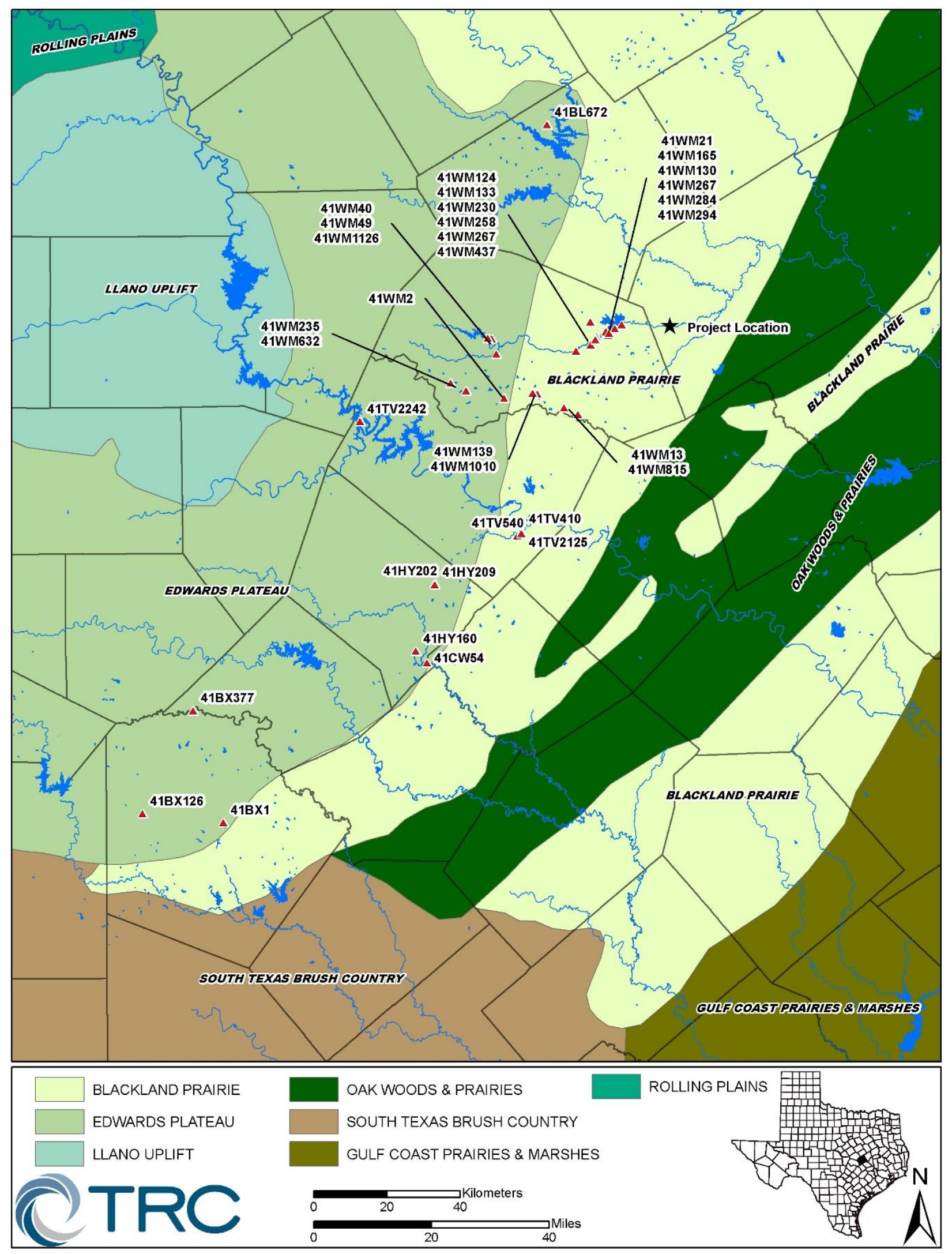

Figure 3-3. Selected Late Archaic Sites in the vicinity. 


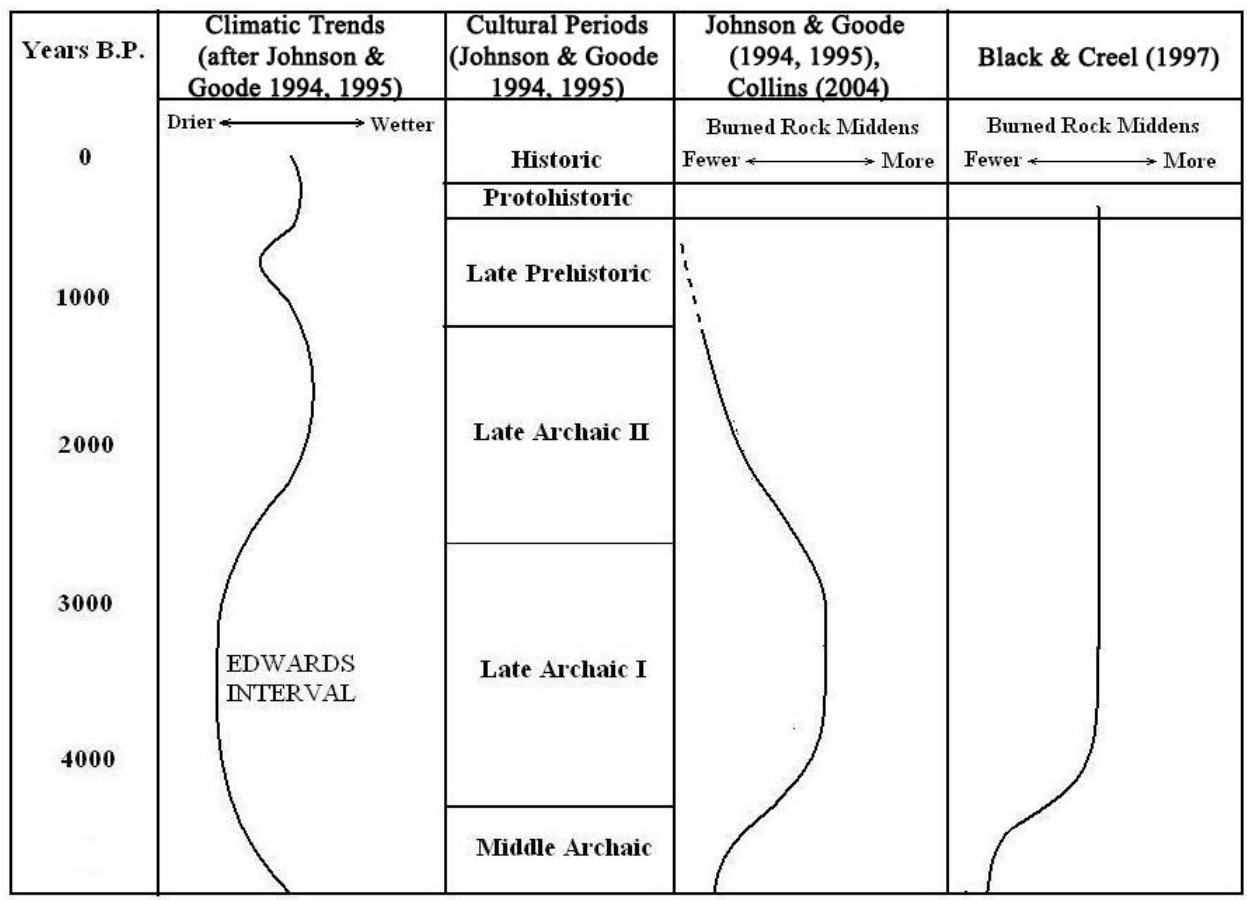

Figure 3-4. Schematic illustration of interpretations of intensity of burned rock midden formations through time.

Burned rock midden distribution studies show the most intense concentration of middens in southwest Texas around the Del Rio region (Mauldin and Nickels 2003). Few counties east of the Edwards Plateau reveal many middens. Less than one percent of the recorded sites in Milam County are reported to have burned rock middens (Mauldin and Nickels 2003:226). A potential reason for their limited numbers in the Blackland Prairie is the lack of rock for extensive cooking of the bulk resources such as bulbs and tubers. However, a few known sites such as Rice's Crossing (41WM815) (Brownlow 2003), 41BL672 (Carpenter et al. 2006) Holt (41HY341) (Brownlow 2004), and 41BL1214 (Griffith and Kibler 2005) all revealed large burned rock oven features that appeared to have cooked geophytes in Blackland Prairie settings. At Berdoll, five radiocarbon dates on wood charcoal from Feature 11 date a $2.0 \mathrm{~m}$ diameter rock oven to a range of 7854 to 8103 B.P. (Karbula et al. 2011). At Holt, two radiocarbon dates, one of $4740 \pm 40$ B.P. (Beta-191422) on wood charcoal and one of $5160 \pm$ 40 B.P. (191738) on Rabdotus snails, date a $3.5 \mathrm{~m}$ diameter earth oven in Zone III (Brownlow 2004). Both sites document long-term usage of rock ovens in the Blackland Prairie and testify to the resource availability over that long-time span. Rock was apparently available in some areas and geophytes appear one food resource in the Blackland Prairie region that was both available and cooked/utilized.

Other than various plant resources that were bulk processed in earth ovens and rock features associated with middens, bison were also part of the subsistence base during certain periods within the Late Archaic, principally associated with Montell points (Mauldin et al. 2012). Bison bones from the Barton site (41HY202), specifically Feature 17, yielded bone collagen radiocarbon dates of $1903 \pm$ 96 B.P. (GX-15539) and $2169 \pm 95$ B.P. (GX15540) (Collins 1994:186). This is the same period that bison were also present in the Lower Pecos region as evidenced by the massive bison kill in Bone Bed 3 at Bonfire Shelter (41VV218) associated with Castroville and Montell points (Dibble and Lorrain 1967) and northwest in Tom 
Green County at 41TG91 (East Levee) associated with Marcos points (Creel 1990). Bison bones have also been recovered from Levels 6 and 7 at 41HY160 in San Marcos and four were radiocarbon dated to between ca. 2475 and 3000 B.P. (Lohse 2013). Apparently, bison were widely distributed across much of Texas during the Late Archaic. However, few bison remains have been identified from excavated sites in the Blackland Prairie (e.g., 41WM130 [Bond 1978]; 41WM230 [McDonald 1982]; 41WM13 [Johnson 2000]; 41WM815 [McClure 2003]; 41CW54 [Schroeder and Oksanen 2002]; 41MM340 [Meissner and Mahoney 2003]; 41WM1010 [Nash 2006]; and 41TV540 [Meissner 2011]). As an example, only 1 of 31 features at 41WM130 yielded identifiable bison bones, which is from a nearly 4,000 piece assemblage (Bond 1978). Deer were also a part of the consumed resources (e.g., Bond 1978; McDonald 1982b; McClure 2003; Nash 2006) as were riverine resources that included mussels (e.g., Howells 2003; Howells et al. 2003; Marie 2006; Gardner 2006). Both deer bones and mussel shells were directly associated with the Early Archaic features (ca. 7854 to 8066 B.P.) at Berdoll (Karbula et al. 2011). The latter example documents the long-term usage of deer and mussels as two important food resources exploited in a Blackland Prairie setting.

Plant subsistence evidence is generally sparse for many Late Archaic sites in the southern Blackland Prairie region. However, a few investigated sites in the Blackland Prairie, such as Armstrong (41CV54) (Dering 2002); Rice's Crossing (41WM815) (Dering 2003a); 41TV540 (Dering 2011); Shepherd (41WM1010) (Dering 2006); Toyah Bluff (41TV441) (Karbula et al. 2001); and Berdoll (41TV2125) (Karbula et al. 2011) from different time periods definitely document geophytes were available and often sought in this region. Nuts from various trees such as oaks (Quercus sp.), pecans (Carya sp.), and walnut (Juglans sp.) were exploited and available throughout time. Bryan Fox (41WM124) and Loeve-Fox (41WM230) are two sites where wildrye grass (Elymus sp.) seeds and needlegrass (Stipa sp.) seeds have been documented (Crane 1982). Also at Loeve-Fox were charred grape seeds (Vitis sp.), dock seeds (Rumex sp.), possibly wildrice (Zizania sp.), sunflower seeds (Helianthus sp.), and pokeberry seeds (Phytolacca sp.) (Crane 1982:15-7).

Lithic resources for the production of stone tools are common along the major rivers and creeks. Brushy Creek, San Gabriel River, Little River, and other streams headwater to the west in the Edwards Plateau and move high quality cherts from the Plateau eastward down the valleys. Observations indicate that high density of Edwards chert lies in the Brushy Creek basin (Kibler 2000). At least two named varieties of chert such as Round Rock (black) and Georgetown (steel gray to bluish-gray) are along Brushy Creek (Kibler 2000). Eastward along high and low stream and river terraces, gravels are present that would include chert (Barnes 1981), and therefore, available for aboriginal use.

Cemeteries were in use in central Texas during the Late Archaic as indicated at sites such as the following. The Bessie Kruze site (41WM13) in Williamson County yielded a massive grave with three comingled skeletons in Zone II at around 2440 B.P. (Beta-94000) with Pedernales points among the bones. Two human cremations were also in Zone III dated to around 3020 B.P. (Beta-94002, Johnson 2000). At Olmos Dam (41BX1) in Bexar County far to the south (Lukowski 1988), at least some, if not all 13 burials attributed to the Late Archaic period. At least two infant burials, one flexed and associated with grave inclusions, including whitetail deer antlers, traces of ocher, and chert cobbles, were associated with charcoal radiocarbon dates of $2200 \pm 70$ B.P. (Tx-3989) and $1920 \pm 160$ B.P. (Tx-3993). Isolated burials are also present as indicated by a semiflexed 35 to 45 -year old male at 41LL356 buried $2.2 \mathrm{~m}$ deep in an alluvial terrace in Llano County (Bement 1993). This body was associated with a complete Ensor dart point near the dorsal side of the spine opposite 
the lower thoracic vertebrae, which might have caused the death. Another example is the Carpenter Bend site (41TV2242) in Travis County where a single, adult (greater than 50 years) male burial was radiocarbon dated to 1350 B.P. This was a tightly flexed burial below several rock slabs (Malof and Taylor 2011). Another isolated burial, radiocarbon dated to 2015 B.P. (UCIAMS-111181), was from Spring Lake (41HY160) (Lohse et al. 2013). There a single adult male was buried in a flexed position with no grave goods. Carbon isotope data from the latter two individuals (-18.3\%o and -18.6\%) indicates these individuals were consuming inland plant and animal resources as expected (Lohse et al. 2013; Malof and Taylor 2011).

The current and sporadic evidence over a long-time period from the various investigated sites in the Blackland Prairie indicate small, highly mobile family groups that employed a broad spectrum resource subsistence strategy utilized this and the adjacent regions. The Late Archaic is generally viewed as a continuation of a generalized collection adaptation strategy with population densities increasing from the proceeding period. In viewing the distribution pattern of 17 Castroville-MontellMarcos sites in Camp Bullis in Bexar County,
Kibler and Scott (2000:184) believe these to represent campsites of specialized bison-hunting peoples, although they discovered that 65 percent occur in zones with little or no potential for bison.

Recently, Lohse (2013:141) stated that "Archaeologists working in Central Texas often lack a clear and detailed understanding of many Archaic-period sequences, developments, and adaptations." We still need to address these short comings through larger and more focused data recovery projects combined with more intensive analyses of diverse data sets.

\subsection{SUMMARY}

Although scattered excavations that represent at least a few of the 14 time units (see Collins 2004) have occurred in the Blackland Prairie across the general central Texas region, few sites with good to excellent context have yielded significant cultural assemblages that represent the earlier part (2500 to 4500 B.P.) of the Late Archaic period. The model for the use of the Blackland Prairie proposed by Shafer and Bryant (1976) has not been thoroughly assessed. Much more in-depth investigations are needed to understand what occurred in the Blackland Prairie through time and for the little known period. 


\subsection{METHODS}

J. Michael Quigg and Paul M. Matchen

\subsection{FIELD METHODS}

From May 7 through May 25, 2012, TRC archeologists conducted the assessment phase through mechanical trenching within the approximately 58-by- $8 \mathrm{~m} \mathrm{APE/target}$ area that TxDOT delineated as the known archeological site boundary. A $1 \mathrm{~m}$ wide, flat bladed bucket was employed on a backhoe, provided and operated by TxDOT personnel, to dig four backhoe trenches (BT) 1, 2, 3, and TxDOT 7 that totaled nearly 42 linear meters (Figures 4-1 and 4-2). Trenches 1 and 2 were dug at the northern end of the APE and perpendicular (east-west) to the farm-to-market road. Trench 3 was dug at the southern end of the boundary in a north-south line along the western boundary of the existing ROW (Table 4-1). TxDOT's Trench 7 along the western fence was reopened as it provided the highest density of cultural materials, which allowed firsthand view of the initially identified cultural zone(s). These trenches served to target alluvial deposits in the top $150 \mathrm{~cm}$, permit easy access to deeper subsurface deposits for hand-excavation, reveal buried archeological materials and features, allow documentation of the $150 \mathrm{~cm}$ of natural and cultural deposits present, and allow a preliminary assessment of the buried deposits to the extent possible within the site area identified by TxDOT. Placement of trenches provided appreciable coverage of the Barrett site while preserving sections for possible data recovery, if needed.

Trench walls were inspected for cultural remains and their stratigraphy was documented and sampled by the geoarcheology team of Charles Frederick and Brittney Gregory. TRC personnel also collected humate samples from specific depths as guided by the geoarcheologists.

Following the excavation of trenches, handexcavations by TRC archeologists occurred with the digging of nine 100-by-50 cm test units (TUs) off the sides of the trenches (Figures 4-1 and 4-3). Test units were numbered 1 through 9 in sequence of excavation. The first four TUs were excavated across the site in three different trenches (BTs 1, 2, and 3 ) from the ground surface to a maximum depth of 150 or $160 \mathrm{cmbs}$. These initial four handexcavation units (TUs 1 to 4) were distributed to acquire an adequate sample of cultural artifacts, and identify cultural zones to target with additional hand-excavation units.

Following the excavation TUs 1 through 4, it became clear that the upper $50 \mathrm{~cm}$ of alluvial deposits were nearly void of cultural artifacts. With that discovery and documentation, permission was sought and granted from TxDOT archeologist Jason Barrett that in the next test units excavated that the upper $50 \mathrm{~cm}$ could be discarded without screening.

All hand-excavated sediments were dry screened through $6.4 \mathrm{~mm}$ (1/4 inch) hardware mesh, except the top $50 \mathrm{~cm}$ in TUs 5 through 9. Cultural materials, plus Rabdotus and other snail shells, were collected and recorded from each screened level. All cultural artifacts were collected and bagged by unit and level provenience. Formal artifacts recognized in the field were not handled with bare hands before bagging in an attempt to preserved microfossils that might be on them. The burned rocks were difficult to discern in the field as small chert pebbles/cobbles were used and had often fractured into many small pieces that resembled knapping debris. Nonchert pebbles were also used as cooking rocks and these were generally quite small and collected as other cultural debris. Mussel shells were also collected focusing primarily on the larger and potentially identifiable pieces, with tiny nondiagnostic fragments not retained.

Clusters of cultural materials recognized in the field were treated as features and recorded on the appropriate level record plus an individual feature form was completed for each. That portion of the 


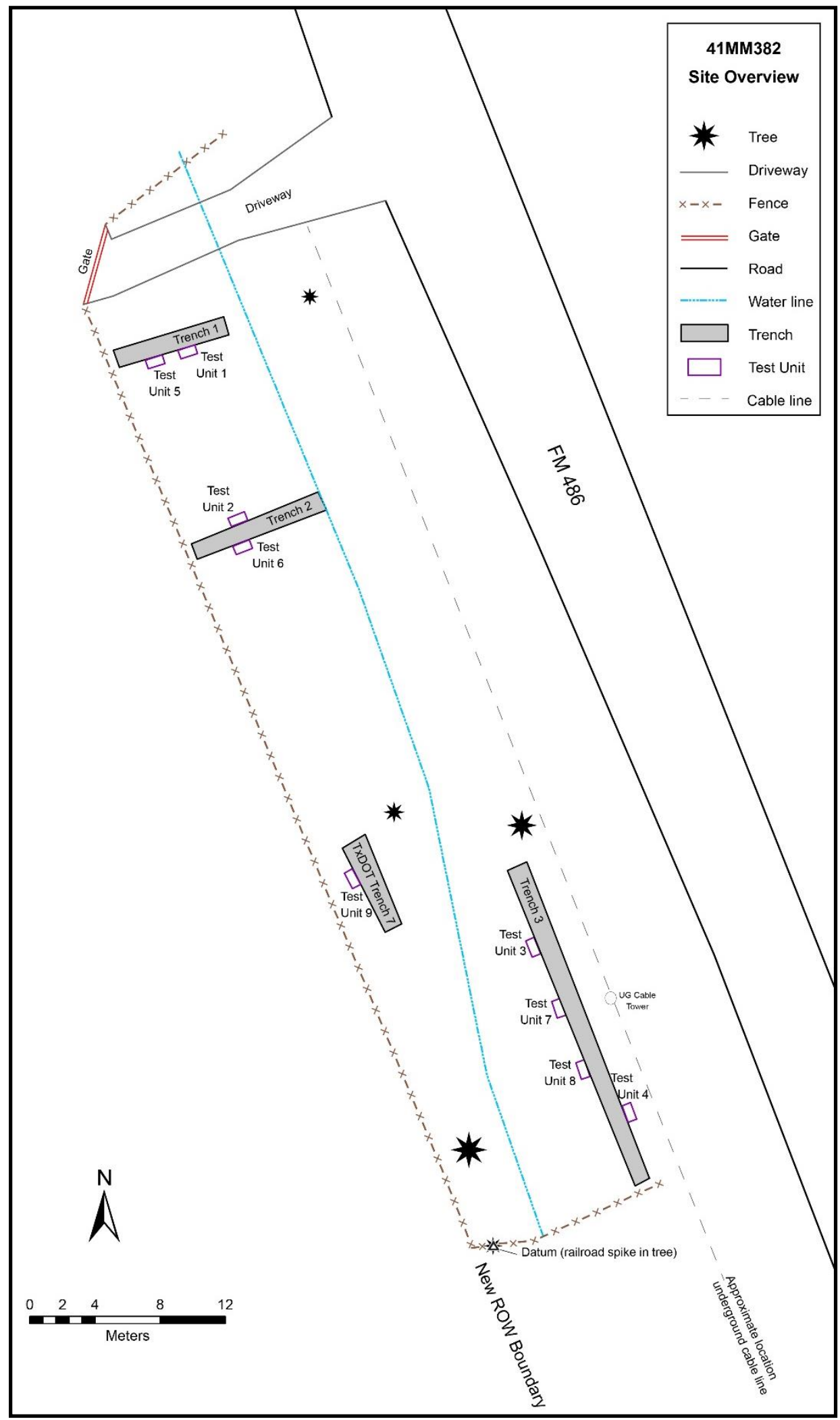

Figure 4-1. Site map showing locations of backhoe trenches and test units within TxDOT ROW. 


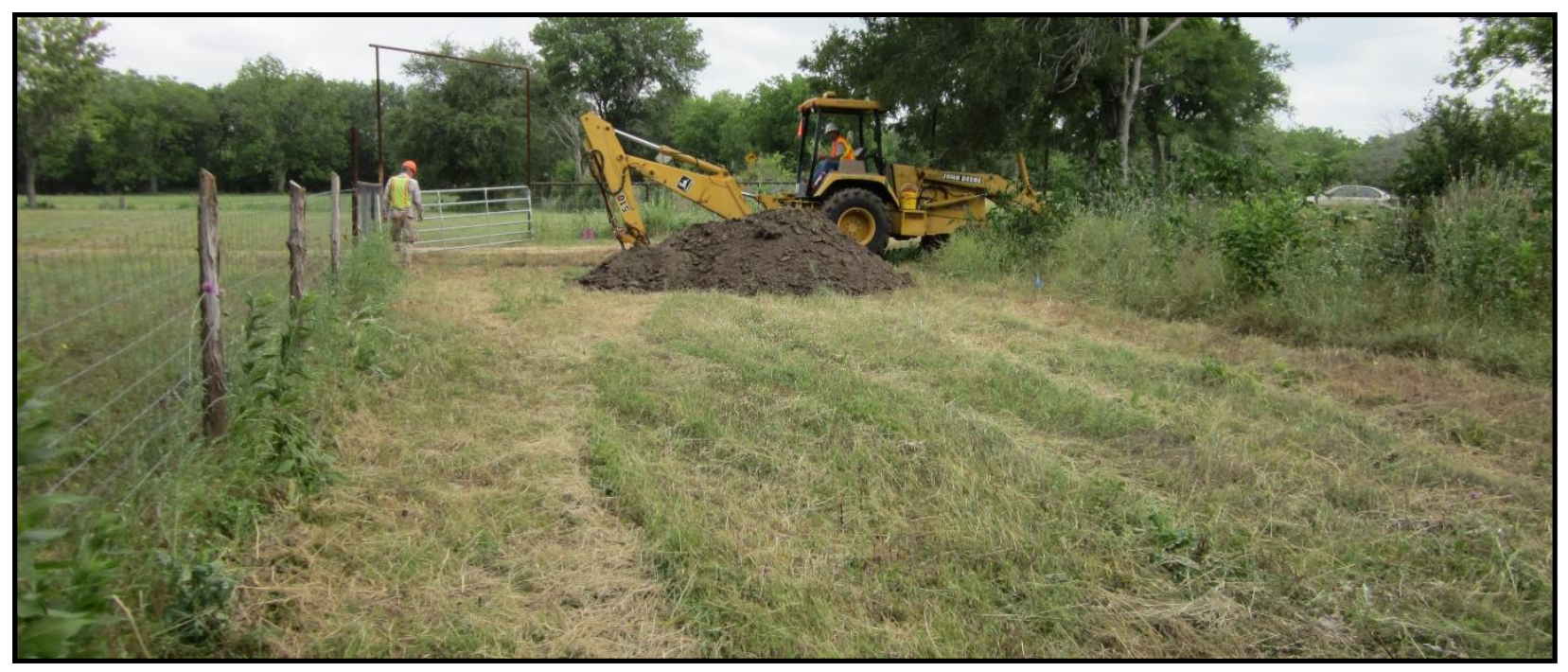

Figure 4-2. Backhoe trenching at northern end of site boundary. New TxDOT ROW fence on left and a buried water pipeline below tall weeds on right.

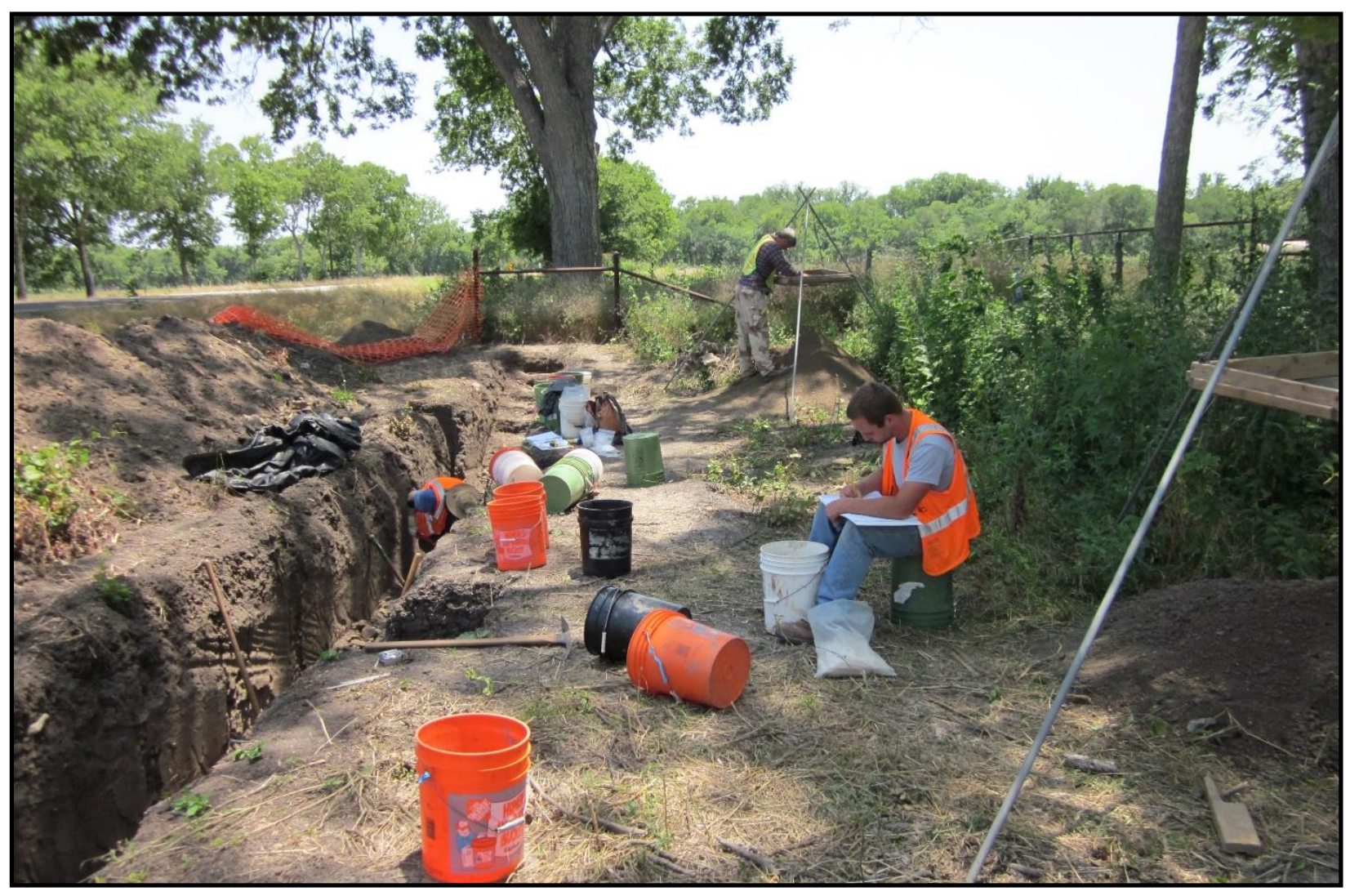

Figure 4-3. Hand-excavations along BT 3 at southern end of targeted site. 
Table 4-1. Data Concerning the Backhoe Trenches at 41MM382.

\begin{tabular}{|c|c|c|c|l|}
\hline $\begin{array}{c}\text { Trench } \\
\text { No. }\end{array}$ & $\begin{array}{c}\text { Length } \\
(\mathbf{m})\end{array}$ & $\begin{array}{c}\text { Width } \\
(\mathbf{m})\end{array}$ & $\begin{array}{c}\text { Depth } \\
(\mathbf{c m b s})\end{array}$ & \multicolumn{1}{|c|}{ Occupations } \\
\hline 7 & 4 & 1 & 175 & $2+$, ca. 115,135 \\
\hline 1 & 6 & 1 & 155 & $2+$, ca. 120, \\
\hline 2 & 8 & 1 & 160 & $3+$, ca. $75-90,120-130,160+$ \\
\hline 3 & 22 & 1 & 160 & $2+$, ca. 145,160 \\
\hline
\end{tabular}

feature recognized in the test unit was drawn, photographed, and artifact samples from the feature collected. Bulk sediment samples from identified features were collected without screening and transported to the TRC laboratory in Austin for potential further processing.

Once the $11.4 \mathrm{~m}^{3}$ of hand-excavations were completed, the site area, trench and unit locations, and pertinent characteristics of the area were mapped with a total mapping station by TRC personnel to be downloaded and used for report map production. At the completion of the fieldwork of this NRHP eligibility assessment project, the open excavations were backfilled by TxDOT personnel from the Bryan District.

\subsection{LABORATORY PROCEDURES AND TECHNICAL ANALYSES}

TRC artifact processing entailed washing, sorting, and labeling most cultural materials, except burned rocks and mussel shells. Prior to washing, all bags of lithic debitage were examined for formal and informal tools, including flakes with modified edges. All identified stone tools were bagged separately without washing or further handling. On unwashed specimens, a portion of one surface was cleaned so that an archival stable ink label could be placed on the artifact. Nitrile gloves were used when handling these selected tools.

All cultural materials were assigned Provenience Numbers (PNUMs) and entered into an electronic database. These unique PNUMs were assigned to individual excavation levels, as well as other proveniences. All provenience information available and pertinent data from the collection bags and level records were entered into a Microsoft Access format database.

TRC's cataloging system assigns strings of numbers to artifacts that encode information on provenience, artifact class, a unique identifier, and samples taken from the artifact or lot for specialized analyses. The PNUMs (e.g., \#155) were assigned to lithic debitage, stone tools, and burned rocks. PNUMs are sequential numbers that designate the overall provenience unit (i.e., excavation unit, backhoe trench, modern ground surface) and level, or depth, within that provenience unit and can be cross-referenced to a master list of PNUMs. Within each PNUM, the various artifact classes were assigned a secondary designation referred to as the artifact class number: lithic debitage (001), faunal bone (002), burned rock (003), soil (004), feature (005), shell (006), macrobotanical remains (007), ceramic sherds (008), and historic material (009). Individual tools and other unique items were assigned unique artifact numbers starting with the number 10 within the same unit and level designated by the PNUM. Thus, each specimen was assigned a PNUM and an artifact number (e.g., \#155-10, \#155-11, and \#155-12).

About one in ten items (10 percent) occurring in bulk material classes (e.g., chert debitage) within specific provenience units (e.g., a level) were individually labeled as per standard curation guidelines. Specimen size was also a major consideration for labeling purposes, as many lithic pieces are less than $1 \mathrm{~cm}$ in diameter and were not labeled. Artifact labeling consisted of inscribing the 
State of Texas Archeological Site Trinomial (41MM382) and the catalog number on designated artifacts using black indelible ink. After the ink was dry, the artifact labels were coated with clear Acryloid B-72 with reagent-grade acetone solvent to preserve the inscriptions.

Permanent paper tags were included with each individually bagged artifact or class of artifacts collected from a single provenience. These tags include the site trinomial, provenience information (unit and depth), the class or type of artifact(s), the date of excavation, the excavator's initials, and the quantity of items in the bag. These permanent tags were printed on acid-free, $30.4 \mathrm{~kg}$ (67 lb.) card stock and filled out with pencil.

\subsubsection{Analytical Methods}

Artifacts were subjected to different metric, nonmetric, typological, and specialized analyses, such as use-wear analysis. A set of predefined attributes for each material class were first encoded on paper, and then entered into TRC's electronic database management system utilizing Microsoft Access 2010 software, which constitutes the master database for the investigations at 41MM382. A copy of this database is provided on the CD-ROM attached to the back cover of this report. The specific data recorded for each class of artifact are presented below. Analytical methods pertinent to each data class and the various secondary suites of software used for specialized analyses are discussed in detail in the appropriate parts of this report.

\subsubsection{Chipped Stone Artifact Analysis}

A protocol for analysis of debitage and chipped stone tools has been developed by TxDOT archeological staff (TxDOT ENV 2010) in an effort to standardize data collection and presentation in analytical and interpretive chapters of archeological reports sponsored by TxDOT. When possible, terminological and taxonomic uses follow those terms for this assemblage (Figure 4-4).

\section{Bifaces}

Bifacial tools, whether finely or crudely produced, appear to have completed the manufacturing process. This is evidenced by secondary retouch, edge straightening, hafting preparation, notching, and similar characteristics. Bifaces are defined predominantly on the basis of morphological characteristics, but they may also have functional associations (e.g., cutting, piercing, chopping, drilling). Bifacial tools exhibit purposeful, usually patterned, flake removals on both faces (ventral and dorsal). Most or all of both faces may be covered with flake scars, and in some cases one face may be completely modified, whereas the opposite face exhibits only partial modification. Bifaces may be fashioned either from large bifacial cores or from flakes. Included within this overall morphological category are diverse functional groups such as projectile points (see below).

\section{Projectile Points}

Projectile points are a functional subset of the biface class specifically designed to be hafted to the distal end of a shaft used in stabbing, throwing, or shooting to penetrate animal hides and flesh and kill the animal. Projectile points are bifacial tools given their final form by means of fine secondary retouch, usually with basal modification in the form of notching, stemming, or thinning of the proximal end for purposes of hafting. Dart points, arrow points, and indeterminate dart/arrow points are all classes of projectile points. Dart points are those employed to tip hand-held darts or spears, arrow points are used to tip arrows, and indeterminate points are, as the name implies, of uncertain usage. Whereas dart points are usually manufactured from bifacial preforms, arrow points are often manufactured on thin flakes.

Projectile points were assigned to recognized types whenever possible. In traditional archeological literature, projectile points are normally referred to by their typological designation, which are usually based on a set of morphological characteristics, 


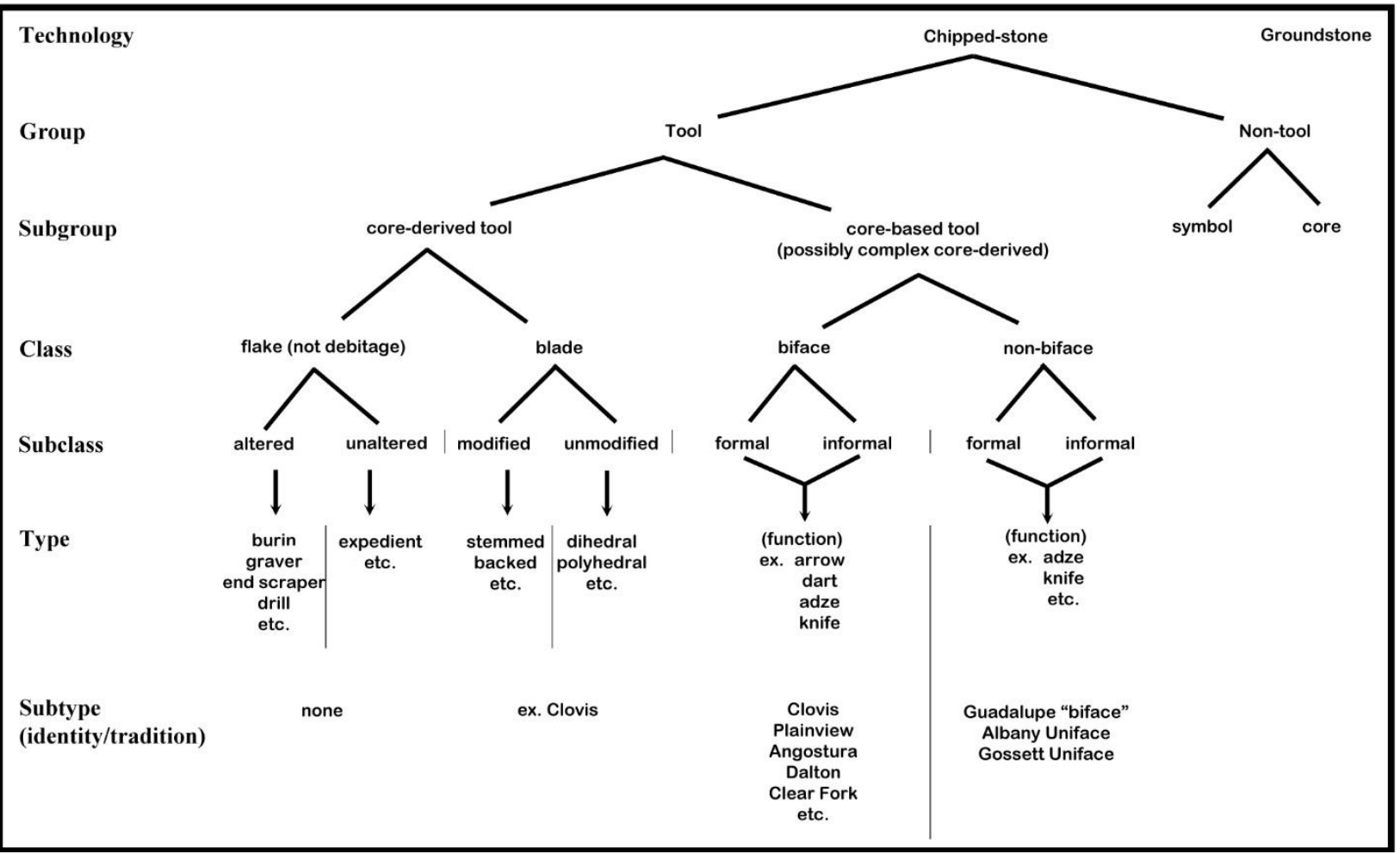

Figure 4-4. Chipped stone artifact analysis flowchart.

shared in common by groups of similar points, which generally focus on the hafting modification. Point classifications were conducted by TRC's personnel in reference to established point typologies in use in Texas archeology (Suhm and Jelks 1962; Turner et al. 2011).

\section{Scrapers}

Scrapers are a specific type of unifacial tool that have at least one intentionally modified working edge. In some instances, bifacial modification maybe present, but in such cases the intentional retouch tends to be located on the dorsal flake surface whereas the ventral surface tends to exhibit primarily use-related flake scars. Based upon the location of the primary working edge, scrapers are subdivided into end, side, or combination types. End scrapers are pieces with retouch, restricted primarily to either the distal or proximal end of the flake blank, generally producing a convex working edge. The opposing end of the piece may bear some minimal retouch, presumably to facilitate hafting.
Side scrapers are pieces with retouch present on one or both lateral edges of the flake blank. Working edges may be convex, straight, or concave. On combination scrapers, marginal retouch may appear along the end as well as along one or more lateral edges of the blank. As implied by the name of this tool, the primary function of scrapers is presumed to relate to scraping relatively soft materials such as animal hides or vegetable matter, or slightly harder materials, such as wood or possibly antler or bone.

Twenty-eight metric and nonmetric attributes were recorded for scrapers. Many measurements relate to the number, location, and characteristics of the working edges on the tool. Metric measurements of length, width, thickness, and weight were recorded for each specimen even if it was broken.

\section{Unifaces}

Unifaces are those tools that exhibit flake scars on one face only. Like bifaces, unifaces are defined based predominantly on morphological characteristics, but they also tend to have functional 
associations (e.g., scraping, planing, cutting, engraving). Unifacial tools exhibit purposeful flaking across most or all of one face, whereas the opposite face most often remains flat and unmodified. Unifaces may be fashioned from cobbles or flakes and include such functionally diverse groups as scrapers, gouges, edge-modified flakes, gravers, and spokeshaves. One or more edges of a unifacial tool may exhibit manufacture and/or use-related flake removals that may be patterned or random. To some degree, unifacial tools form a continuum ranging from formal tools exhibiting intentional, patterned, and manufacturerelated edge flaking to informal, expedient tools that show only use-related edge scarring. The former tend to fall within the scraper and gouge categories, whereas the latter are generally classified as edge-modified flakes.

\section{Edge-Modified Flakes}

Edge-modified flakes are minimally modified flakes, flake fragments, or pieces of angular debris that are characterized by one or more areas of flake scarring along margins. The edge flaking may be patterned or unpatterned, continuous or discontinuous, and may result from use-related activities or from intentional pressure retouching to prepare an edge for use. Many edge-modified flake tools exhibit combinations of these characteristics, and many have more than one working edge. The modifications, however, usually are restricted to the edges and do not significantly alter the original flake form. Such edge modifications may be either unifacial or bifacial. Edge-modified flakes are usually considered 'expedient' tools, pieces of raw or minimally modified material that are utilized for a short time, and subsequently discarded soon after use.

\subsubsection{Lithic Debitage Analyses}

Chipped stone or lithic debitage is unmodified debris as a result of stone tools manufacture and maintenance. During the analysis process, the laboratory technician uses macroscopic analysis for flake or use scars indicating modification on each flake to separate any possible tools. All debitage was counted from TUs 1 through 9; however, only TU 9, Level 7 was subjected to detailed analysis to understand the general character of the site debris assemblage. This unit and level was selected because it contained a high frequency of archeological material. Selected specimens were also examined under ultraviolet (UV) light to isolate any debitage inconsistent with Edwards Formation chert.

The lithic debitage was first size graded as specified by screen manufacturer Gilson Company, Inc. into $6.3,12.5,19.0$, and $26.5 \mathrm{~mm}$ size groups. Each specimen was then sorted into platform bearing and nonplatform bearing groups. Nonplatform bearing specimens were treated as shatter and weighed in bulk by provenience (specific to Level and TU). Platform-bearing specimens were examined individually and sorted into one of four classes: flat, multifaceted, crushed, and cortical. Other attributes documented include the presence/absence of heat alteration, cortex percentage (i.e., none, 1 to 25 percent, 26 to 50 percent, 51 to 75 percent, and 75 to 100 percent) and raw material type. Specimens were then weighed and findings entered into a database spreadsheet. Those that lacked a platform were grouped together on a single line, counted and weighed.

Lithic debitage lacks any macroscopic indications of use or modification. Pieces that exhibit any sign of use-wear or intentional modification are placed in the appropriate tool category.

\subsubsection{Mussel Shell Analysis}

The mussel shell was compared to TRCs extensive modern and prehistoric comparative collection that has been identified and individually labeled. Original identifications were performed by Dr. R. G. Howells. To confirm identification, the specimen was compared to other modern pictures. Habitat data were obtained from literature sources (i.e., Howells et al. 1996). 


\subsubsection{Analytical Techniques}

Two outsourced analytical techniques, radiocarbon dating and starch grain analysis, were performed on a selected suite of artifacts. These two techniques were performed to gain greater insights into, and understanding of, the ages of the deposits and associated cultural materials and provide some indications as to the foods potentially employed in these occupations.

The separate technical reports presented in the appendices (A and B) provide details concerning methods, analytical results, and interpretations. Those results are incorporated into the body of this report. The combined results are used to aid in the formulation of the research direction presented at the end.

\subsubsection{Radiocarbon Dating Analysis}

Charcoal, the preferred material for radiocarbon dating, was not recovered. Consequently, other substances with the potential for organic content provided the only means of potentially obtaining absolute dates. An absolute date can be obtained from organic materials trapped in the sediments and shells, though it may not be as precise as what one might obtain from charred seeds or wood. Direct dating of soil humates and Rabdotus snail shells have been accomplished previously with mixed results (see Frederick 2011 for comparisons and problems with dating these materials). Consequently, one must view these dates as general ballpark dates rather than a narrowly definable points in time. TRC archeologists selected 13 samples; 6 humate samples, 5 Rabdotus clusters, and 2 tiny bone fragments for direct radiocarbon dating and requested approval from TxDOT personnel. Once approved, TxDOT submitted the 13 samples to Beta Analytical Inc., (Beta) in Miami, Florida. Twelve of the 13 samples returned radiocarbon assays.

Beta dates are reported as radiocarbon years before present (B.P.), with "present" being A.D. 1950 using the Libby ${ }^{14} \mathrm{C}$ half-life of 5,568 \pm 30 years. Each sample was measured for Carbon-13 verses Carbon-12 ratios $\left({ }^{13} \mathrm{C} /{ }^{12} \mathrm{C}\right)$ expressed as the delta 13 Carbon $\left(\delta^{13} \mathrm{C}\right)$ and calculated relative to the internationally standard Cretaceous Belemnite Formation at Peedee, South Carolina (PDB or VPDB). Beta's individual laboratory reports with specific details concerning each sample are presented in Appendix A. Individual sample results are also presented and discussed throughout the body of this report.

The Rabdotus snail shells from this site in the Blackland Prairie have likely been feeding on the local vegetation. Therefore, there is not an apparent need for a correction factor to the Rabdotus shell results as there would be for similar shell dates from central Texas with the limestone potentially contributing to yield older dates.

\subsubsection{Starch Grain Analysis}

Starch grain analysis is becoming more widely used in Texas archeology to identify plant resources used by the inhabitants (e.g., Perry and Quigg 2011; Quigg 2011; Quigg et al. 2010, 2011a, 2013a, 2013b). A brief introduction is provided here as background to this discipline for those that might not be familiar with this technique.

Starch grains are microscopic granules that serve as the principal food storage mechanism of plants (Figure 4-5). These grains are found in most plants that include roots and tubers (e.g., crow poison, rain lilies, false garlic, wine cup, and spring beauty), and in the seeds of legumes and grasses, where they are often produced in abundant numbers (Perry personal communication 2008). Starch grains from different plants possess a large variety of speciesspecific forms that have been recognized for some time. Distinctive features of starch grains are genetically controlled and when carefully observed, can be used to identify plant taxa. At least 300 species and varieties of important economic plants from around the world have been described and can 


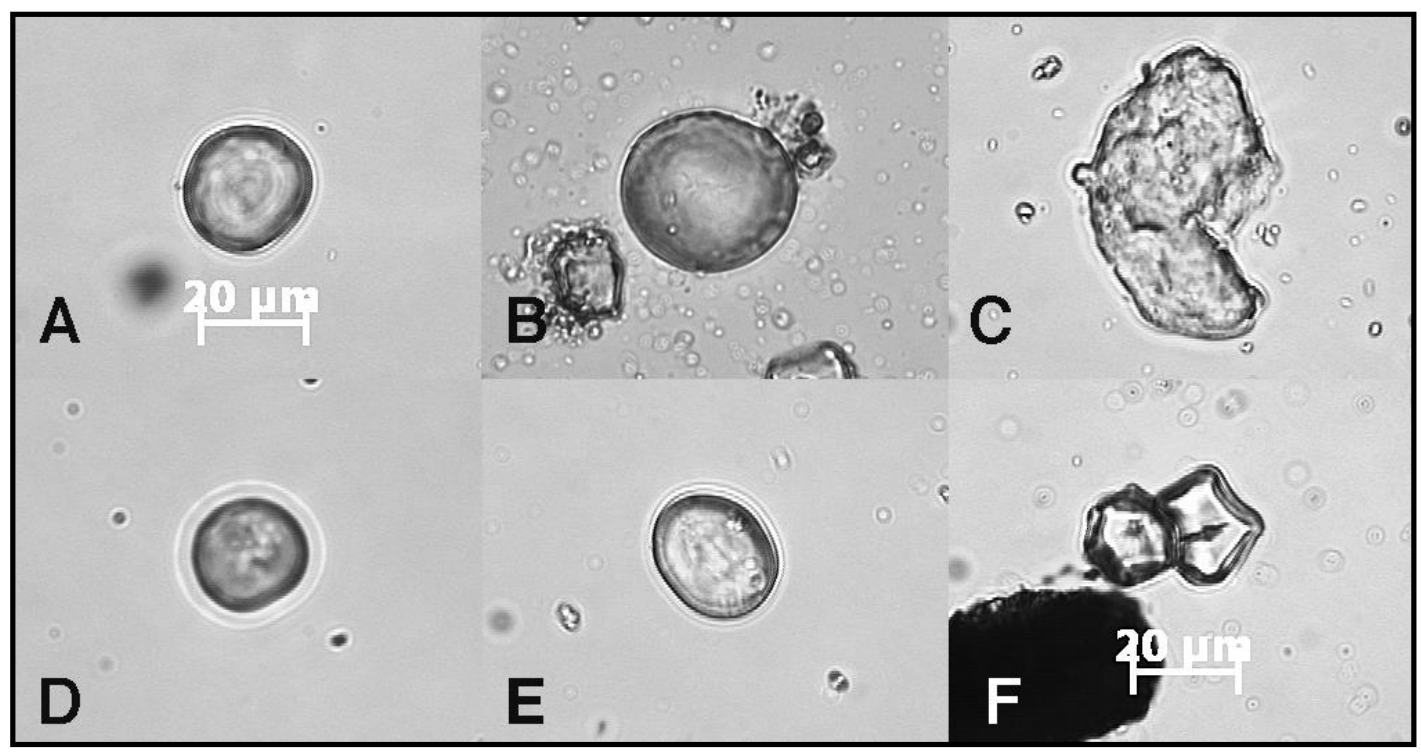

Figure 4-5. Examples of starch grains of wildrye grass recovered from burned rocks at an archeological site (photograph provided by L. Perry).

be preserved in archeological contexts (Piperno and Holst 1998; Piperno et al. 2000). Researchers around the world (particularly in the Neotropics and in Australia) have been using these techniques with excellent results (Perry personal communication 2007). Starch grain remains have significantly increased the knowledge of plant domestication and crop-plant dispersal in various regions (Perry et al. 2006:76-77).

Researchers have employed starch grain analyses to study diet, plant processing, plant domestication and cultivation, tool use, and uses of ceramic vessels. Starch grains have been extracted from soil samples, ceramics, and chipped and ground stone tools to address questions of resource procurement and preparation of foods. Intact starch grains have been extracted from formal and informal chipped stone tools, both washed and unwashed (Perry personal communication 2007). Heat alone does not destroy starches, as they are found in ceramic cooking vessels and in burned rocks (Perry and Quigg 2011; Quigg et al. 2010).

A suite of burned rocks from across the site and from different cultural zones were selected for this initial analysis. The selection process was designed to sample various parts of the site and the various levels of cultural materials to investigate the possible foods involved in the different events represented. It is notable that most burned rocks were relatively small fragments of exploded chert, an unusual type of rock for heating. It was a concern that the slick surfaces of the chert pieces would not retain the starch grains from the foods used in association. Nearly all the burned rocks from this site were small, less than $10 \mathrm{~cm}$ in diameter. Many of the nonchert rocks were small, complete pebbles. Dr. Perry's methods, results, and interpretations are presented in Appendix B. Individual sample results are also presented and discussed in the body of this report.

\subsection{CURATION}

Artifacts collected from this assessment effort are temporarily curated at the offices of TRC in Austin. All stone tools, lithic debitage, burned rocks, field records, and photographs from this assessment are to be permanently curated. Individual artifacts and artifact lots, including all stone tools, lithic debitage, and burned rocks are in clear, zip-locking four millimeter thick polyethylene bags according to provenience. Each polyethylene bag contains an 
archival-quality, acid-free curation tag that lists the site number, provenience data, date of excavation, excavator(s) name, artifact type, and quantity in pencil. Digital photographs were submitted on CDs and a contact sheet and placed in archival photo sleeves for curation. All original field records are on acid-free paper and were placed in acid-free reinforced file folders for curation. The materials, artifacts, records, and photographs will be curated at the Center for Archaeological Studies (CAS) at Texas State University in San Marcos. 


\subsection{GEOARCHEOLOGICAL OBSERVATIONS AT $41 \mathrm{MM} 382$}

Charles D. Frederick and Brittney Gregory

\subsection{SETTING}

The site is situated on the Holocene valley floor of the San Gabriel River about 500 m south southeast of the town of San Gabriel (Figure 5-1). The upland landscape in this area is part of the Taylor prairie originally defined by Hill (1901) and a subset of the Black Prairie. The bedrock cropping out in the uplands flanking the San Gabriel River valley is mapped as the undivided Cretaceous-age Navarro and Taylor Groups that are primarily marl and clay (Barnes 1981). The drainage divides on either side of the valley are capped with broad expanses of alluvial gravel that were described by Hill (1901:346) as "upland alluvium which may in general be referred to as the Uvalde Formation" and are mapped as Quaternary High Gravels by Barnes (1981). The designation of these deposits as Uvalde Formation is still considered by some to be somewhat contentious (cf. Caran 1992), but as Hill (1901:347) noted, these deposits are one of the more prominent attributes of the upland landscape south of the Brazos River "the old alluvial formations are conspicuous features of the Black Prairie east of the Balcones Fault Zone, consisting of flint and limestone gravel embedded in a matrix of white calcareous marl which weathers into a typical black waxy soil." This white marl is today recognized as an advanced stage calcic soil horizon (also known as a petrocalcic horizon, cf. Loomis et al., 1992 for description of the evolution of this feature for a petrocalcic horizon formed in the Uvalde gravels in south-central Texas). The soils in the uplands near the site are mostly mapped as the Branyon and Burleson series which are classified as fine, smectitic, thermic Udic Haplusterts (Ramsey 2004).
A brief reconnaissance of the upland landscape north of San Gabriel reveled an extensive outcrop of gravel eroding from the A horizon of the modern soil that is dominated by chert, quartzite, silicified wood and limestone (Figure 5-2), but no evidence of an underlying petrocalcic horizon was observed. Several Master thesis have been written on the geology and geomorphology of the gravel capped upland surfaces in this area, which are sometimes referred to as the Bartlett Surfaces (after Brigham 1977) or the Taylor Alluvial Fan (after Edwards 1974) and these works describe the outcrop of these gravels in some detail (see also Byrd 1971; Montgomery 1982; 1983). It is clear that these deposits would provide one of the most readily available sources of tool stone for prehistoric inhabitants of this region.

In the immediate area of the Barrett site Holocene valley floor is about $1 \mathrm{~km}$ wide and traversed by two active streams, the San Gabriel River on the south side of the valley and an unnamed Yazoo-like tributary which flows adjacent to the northern valley margin. Vestiges of at least two ancient or paleochannels lie between the active streams in the center of the valley and the site lies in between these two abandoned stream courses.

The active channel of the San Gabriel River lies about $350 \mathrm{~m}$ south of the site and is incised about 6 $\mathrm{m}$ below the valley floor. A narrow inset low water flood plain is present and rises about $2 \mathrm{~m}$ above the thalweg. Examination of the active channel bars beneath the highway bridge reveals that the bed load is largely comprised fine limestone gravels with clasts larger than $5 \mathrm{~cm}$ are rare.

The unnamed tributary of the San Gabriel River that flows along the northern valley wall is fed by several low order streams that drain the upland surface west and north of the town of San Gabriel. It is possible that this stream inhabits an old course of the San Gabriel River given that there is a long, abandoned course of the river immediately upstream that occupies a similar landscape position. 


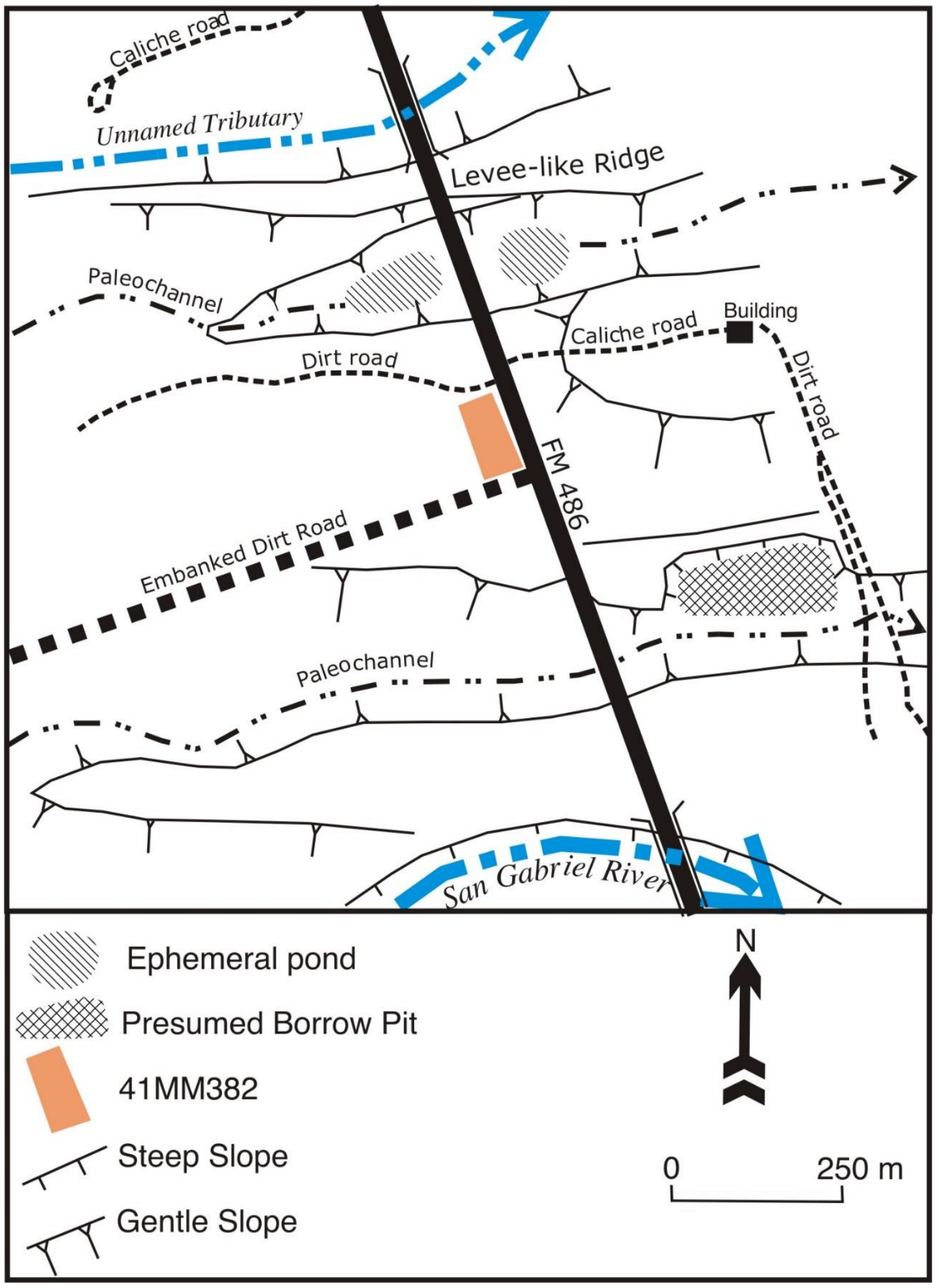

Figure 5-1. Geomorphic map of the immediate vicinity of 41MM382 showing the location of the site with respect to the San Gabriel River, and the unnamed tributary that flows adjacent to the northern valley margin. 


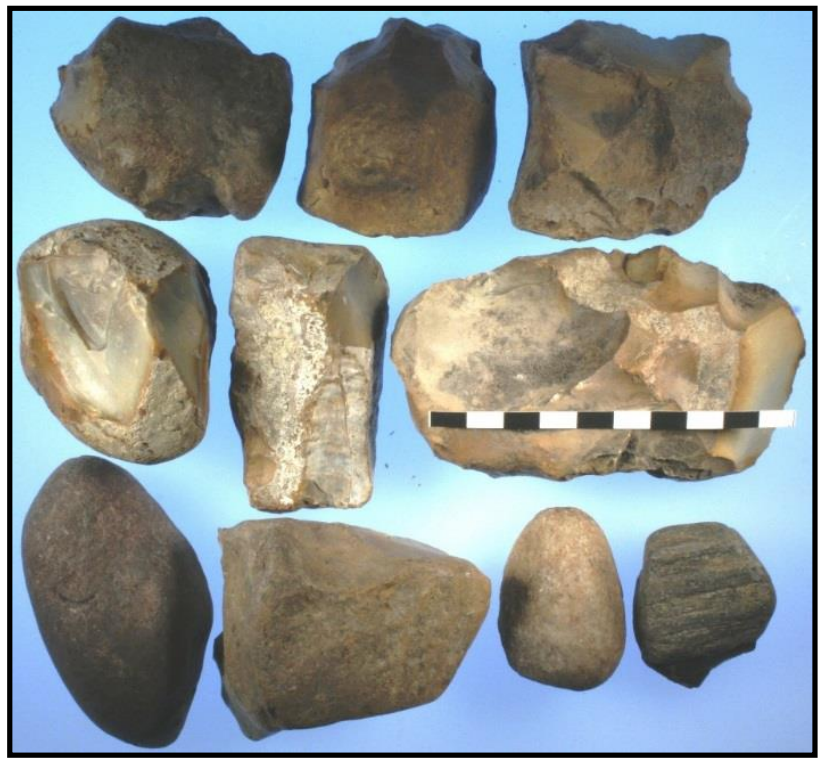

Figure 5-2. General grab sample of upland gravels depicting size, shapes, and types of available rocks.

At this time the southern margin of this creek channel is bounded by a low levee that separates it from the abandoned San Gabriel River channel that lies about $100 \mathrm{~m}$ to the south. Like the San Gabriel River, this creek is incised into the Holocene valley floor and the active channel lies about $5 \mathrm{~m}$ below this surface. A narrow low water floodplain surface is presently adjacent to this channel as well but was not closely examined.

The Barrett site occupies a flat to gently convex surface that lies between the two paleochannels, and in the immediate vicinity of the site this surface is about $130 \mathrm{~m}$ wide (Figure 5-3 upper panel). The soils across the entire San Gabriel River valley floor in this area are mapped by Ramsey (2004) as the Frio silty clay, which are described as "very deep, well-drained, moderately slowly permeable soils that formed in loamy and clayey calcareous alluvium" and are classified as fine, smectitic, thermic Cumulic Haplustolls that exhibit an A-Bk soil profile (Ramsey 2004).

\subsection{METHODS}

The site deposits were exposed by multiple backhoe trenches (BT) and hand-excavated 100-by-50 cm test units (TU) on the sides of trenches. These exposures were described in the field in general accordance with methods described by Schoeneberger et al. (2002). Trench exposures were cleaned with a trowel and shovel and then divided into physically distinct portions called zones, for which the field texture, structure, consistence, reaction, boundary and pedofeatures were described. Then each zone was subsequently assigned a soil horizon designation (Appendix D). A limited suite of 22 small soil samples were collected in $2.5 \mathrm{~cm}$ square plastic boxes for selected laboratory analysis from BT 1 and TxDOT Trench 7 , and the results of this analysis are presented in Table 5-1 and in graphic form on Figure 5-4. For each sample the magnetic susceptibility and particle size distribution were determined and the specific methods employed are described below.

\subsubsection{Magnetic Susceptibility}

Magnetic susceptibility is a general measure of the degree to which a sample may be magnetized, and provides basic information on the magnetic mineralogy of the sample, which may vary owing to a variety of factors, such as depositional processes, soil development, and human occupation. The general application of magnetic susceptibility in archeological studies has been discussed in detail by Dalan (2008) and Dalan and Bannerjee (1998).

\subsubsection{Particle Size Analysis}

The particle size (sand, silt, and clay) distribution (or texture) of each sample was determined on a Beckman-Coulter LS 13-320 multi-wavelength laser seizer. Samples were first subsampled, and then placed in a small beaker on a hot plate to which concentrated (30 percent) hydrogen peroxide was added in order to remove organic matter and a 5. 


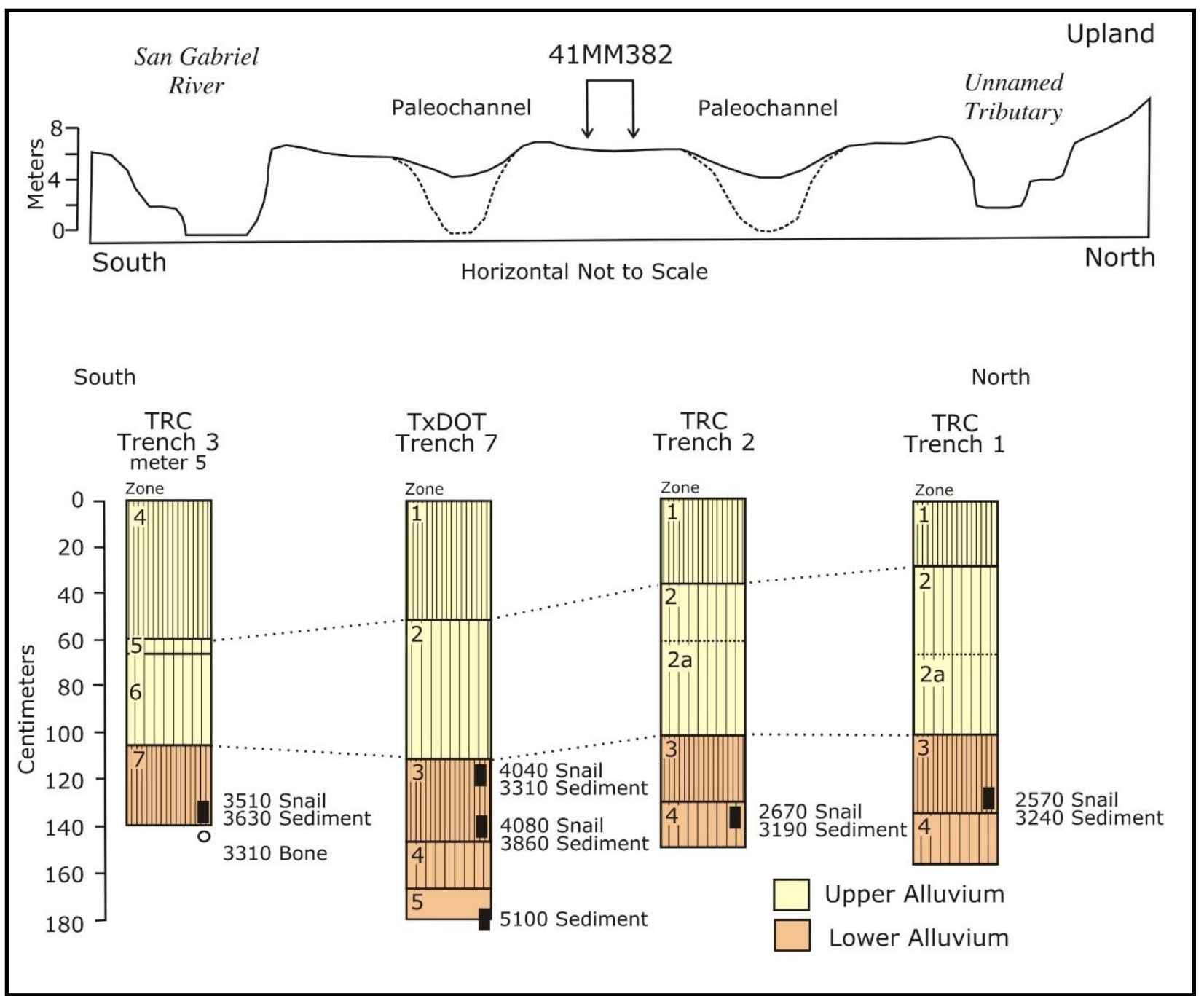

Figure 5-3. Upper Panel: Schematic profile of the San Gabriel River Valley parallel to Highway, showing the location of the modern streams and the two paleochannels. Elevation is estimated. Lower Panel: Comparison of the stratigraphy revealed by each trench organized in order from south (left) to north (right).

percent solution of sodium hexametaphosphate was added to disperse the fine fraction. Samples were brought to a boil and then left on the hot plate until the reaction had ceased or the color of the sediment had changed, at which point they were removed from the hot plate, cooled and then measured on the LS-13-320. The results of these analyses are presented as percentages of sand, silt and clay, as well as in the form of descriptive statistics that are presented in phi units (a negative log base 2 conversion of millimeters). In the phi system, sands exhibit phi values between 0 and 4 , silts between 4 and 9 , and clay greater than 9 phi. The USDA soil texture class for each sample was determined using the Soil Texture Calculator provided by the Natural Resource Conservation Service website (NRCS 2012).

Prior to the eligibility testing phase excavations reported here, TxDOT archeologists J. Barrett and C. Ringstaff examined a number of backhoe trenches in the immediate vicinity of the site, but these were neither described nor interpreted at interpreted at the time of the testing excavations. 


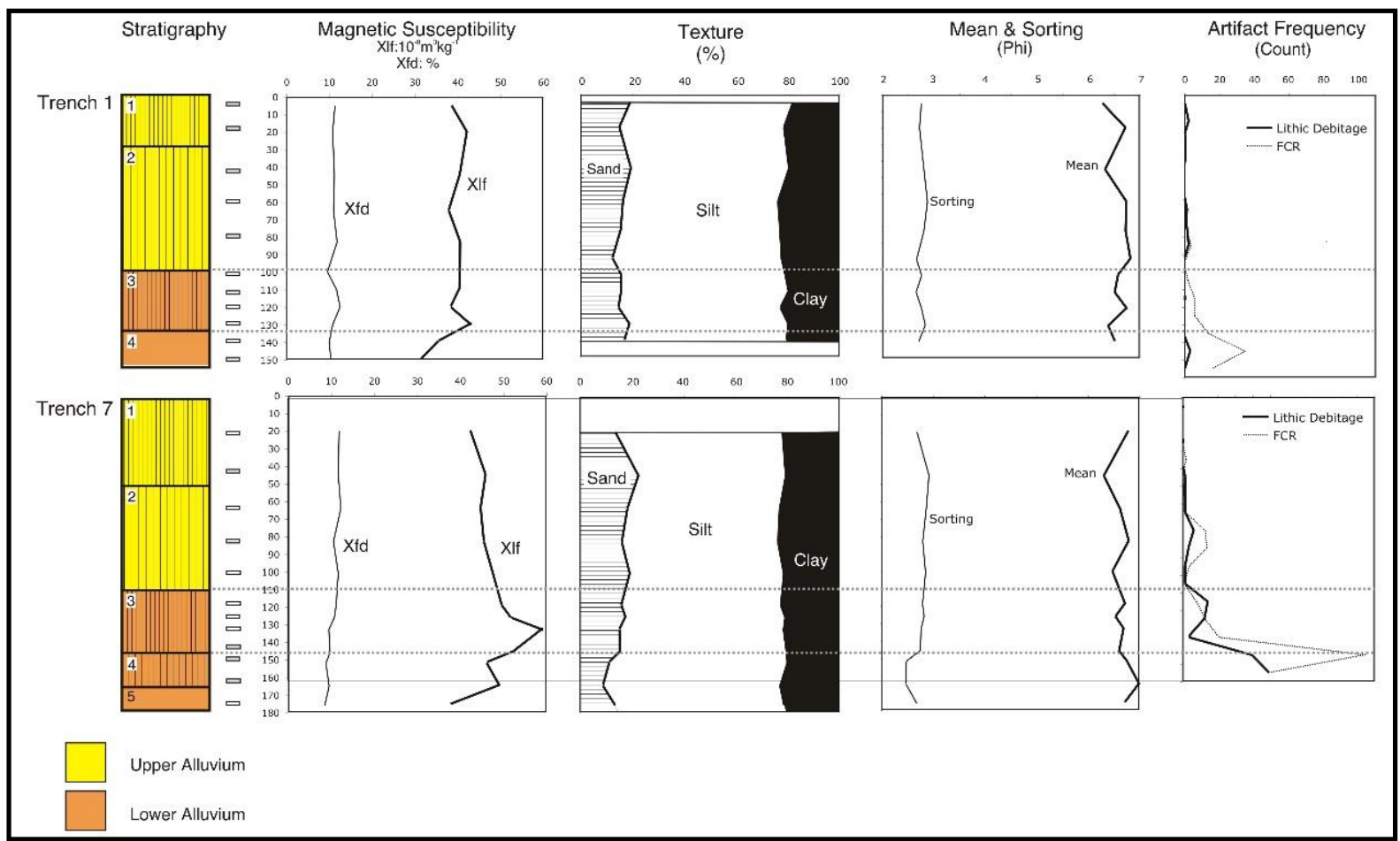

Figure 5-4. Plot showing the results of lab work on the deposits in Trench 1 and TxDOT Trench 7.

Four trenches were excavated at the Barrett site by TRC (Trenches 1 to 3) and TxDOT Trench 7 originally excavated by Barrett and Ringstaff was reopened. All trenches revealed the site to be situated within a floodbasin facies of the San Gabriel River, and exhibited a similar, but very subtle stratigraphic sequence, consisting of two natural stratigraphic units that are here informally described as the Upper Alluvium and the Lower Alluvium. A third deposit, revealed by Trench 3, is a modern introduced fill that forms a road embankment (for a road oriented perpendicular to the roadway) near the southern end of the site. The general stratigraphic relationships observed at the site are summarized on Figure 5-5, and Figure 5-6 show the distribution of these deposits with respect to the cultural material observed on trench walls.

\subsubsection{The Upper Alluvium}

This deposit comprises the upper meter of the profile in most exposures, and exhibits a very subtle $\mathrm{A}-\mathrm{AB}-\mathrm{ABk}$ soil profile. The A horizon consists of a black (10YR 2.5/1) to very dark gray (10YR 3/1) clay that thickened from the north end of the site where it was about $30 \mathrm{~cm}$ thick (in Trench 1) to double that $(60 \mathrm{~cm})$ at the southern end of Trench 3 (see Figure 5-3 lower panel). This deposit exhibits moderate to strong subangular blocky structure. A slightly less melanized deposit lies immediately beneath the A horizon, and this $\mathrm{AB}$ horizon and consists of very dark grayish brown (10YR 3/2) to brown (10YR 4/2) silty clay that in some instances exhibited weak to moderate prismatic structure. In all instances this $\mathrm{AB}$ horizon had moderate to strong subangular blocky structure. In some places this deposit was split in half (Zone 2a in Trenches 1, 2 and Zone 6 in Trench 3) where the upper half exhibited no calcium carbonate filaments and the lower half contained a small number of such features.

No sedimentary stratification or bedding was observed within the Upper Alluvium, and the thickness of this deposit varied little across the site. 
Table 5-1. Results of Analysis of Soil Samples Collected from Trenches 1 and 7.

\begin{tabular}{|c|c|c|c|c|c|c|c|c|c|c|c|c|}
\hline $\begin{array}{c}\text { Sample } \\
\text { Trench } 1\end{array}$ & $\begin{array}{c}\text { Depth } \\
\text { (cm) }\end{array}$ & $\begin{array}{c}\text { Sand } \\
(\%)\end{array}$ & $\begin{array}{l}\text { Silt } \\
(\%)\end{array}$ & $\begin{array}{l}\text { Clay } \\
(\%)\end{array}$ & $\begin{array}{c}\text { USDA } \\
\text { Textural Class }\end{array}$ & $\begin{array}{c}\text { Mean } \\
\text { (phi) }\end{array}$ & $\begin{array}{l}\text { Median } \\
\text { (phi) }\end{array}$ & $\begin{array}{c}\text { Sorting } \\
\text { (phi) }\end{array}$ & $\begin{array}{l}\text { Skewness } \\
\text { (phi) }\end{array}$ & $\begin{array}{c}\text { Kurtosis } \\
\text { (phi) }\end{array}$ & $\begin{array}{c}\text { Xlf } \\
\left(10^{-8} \mathrm{~m}^{3} \mathrm{~kg}^{-1}\right)\end{array}$ & $\begin{array}{l}\text { Xfd } \\
(\%)\end{array}$ \\
\hline 0 & 5 & 19.7 & 62.4 & 17.9 & Silt Loam & 6.3 & 6.0 & 2.8 & 0.1 & 1.0 & 39.0 & 11.5 \\
\hline 1 & 20 & 15.5 & 63.2 & 21.3 & Silt Loam & 6.7 & 6.5 & 2.7 & 0.1 & 1.0 & 42.4 & 10.9 \\
\hline 2 & 45 & 19.9 & 60.8 & 19.3 & Silt Loam & 6.3 & 6.0 & 2.8 & 0.2 & 0.9 & 40.8 & 11.3 \\
\hline 3 & 65 & 16.9 & 59.6 & 23.5 & Silt Loam & 6.8 & 6.4 & 2.9 & 0.2 & 0.9 & 38.3 & 11.1 \\
\hline 4 & 83 & 16 & 61.3 & 22.7 & Silt Loam & 6.7 & 6.5 & 2.8 & 0.1 & 0.9 & 40.9 & 11.9 \\
\hline 5 & 100 & 12.8 & 65 & 22.2 & Silt Loam & 6.8 & 6.5 & 2.7 & 0.2 & 0.9 & 40.8 & 9.7 \\
\hline 6 & 110 & 16.2 & 63.1 & 20.7 & Silt Loam & 6.6 & 6.2 & 2.8 & 0.2 & 1.0 & 40.7 & 11.8 \\
\hline 7 & 120 & 16.2 & 64.3 & 19.5 & Silt Loam & 6.5 & 6.2 & 2.7 & 0.2 & 0.9 & 38.7 & 12.6 \\
\hline 8 & 130 & 15.2 & 62.2 & 22.6 & Silt Loam & 6.8 & 6.5 & 2.8 & 0.1 & 0.9 & 43.4 & 10.9 \\
\hline 9 & 140 & 19.4 & 61 & 19.6 & Silt Loam & 6.4 & 6.1 & 2.8 & 0.2 & 1.0 & 35.8 & 10.1 \\
\hline 10 & 150 & 17.5 & 62.2 & 20.3 & Silt Loam & 6.5 & 6.3 & 2.7 & 0.1 & 0.9 & 31.8 & 10.5 \\
\hline \multicolumn{13}{|l|}{ Trench 7} \\
\hline 1 & 20 & 14.1 & 64.2 & 21.7 & Silt Loam & 6.8 & 6.6 & 2.7 & 0.1 & 1.0 & 42.7 & 11.9 \\
\hline 2 & 45 & 23.1 & 56.4 & 20.5 & Silt Loam & 6.3 & 6.0 & 2.9 & 0.2 & 0.9 & 46.2 & 11.7 \\
\hline 3 & 64 & 18.8 & 58.4 & 22.8 & Silt Loam & 6.6 & 6.4 & 2.9 & 0.1 & 0.9 & 45.1 & 12.3 \\
\hline 4 & 83 & 16.6 & 60 & 23.4 & Silt Loam & 6.8 & 6.6 & 2.8 & 0.1 & 0.9 & 45.8 & 10.7 \\
\hline 5 & 101 & 19.7 & 59.1 & 21.2 & Silt Loam & 6.5 & 6.3 & 2.9 & 0.1 & 0.9 & 47.9 & 11.7 \\
\hline 6 & 119 & 16.5 & 61.1 & 22.4 & Silt Loam & 6.7 & 6.6 & 2.8 & 0.1 & 0.9 & 50.0 & 11.3 \\
\hline 7 & 126 & 18.1 & 61.2 & 20.7 & Silt Loam & 6.6 & 6.3 & 2.8 & 0.1 & 1.0 & 52.1 & 10.8 \\
\hline 8 & 133 & 15.7 & 63 & 21.3 & Silt Loam & 6.7 & 6.5 & 2.8 & 0.1 & 1.0 & 59.5 & 9.5 \\
\hline 9 & 146 & 15.8 & 64.1 & 20.1 & Silt Loam & 6.6 & 6.3 & 2.8 & 0.1 & 1.0 & 52.7 & 9.8 \\
\hline 10 & 152 & 11.8 & 68.3 & 19.9 & Silt Loam & 6.8 & 6.5 & 2.5 & 0.2 & 0.9 & 46.5 & 8.9 \\
\hline 11 & 165 & 9.36 & 68.04 & 22.6 & Silt Loam & 7.0 & 6.8 & 2.5 & 0.1 & 0.9 & 49.5 & 9.7 \\
\hline 12 & 176 & 14 & 64.9 & 21.1 & Silt Loam & & 6.4 & 2.7 & 0.2 & 1.0 & 38.0 & 8.6 \\
\hline
\end{tabular}




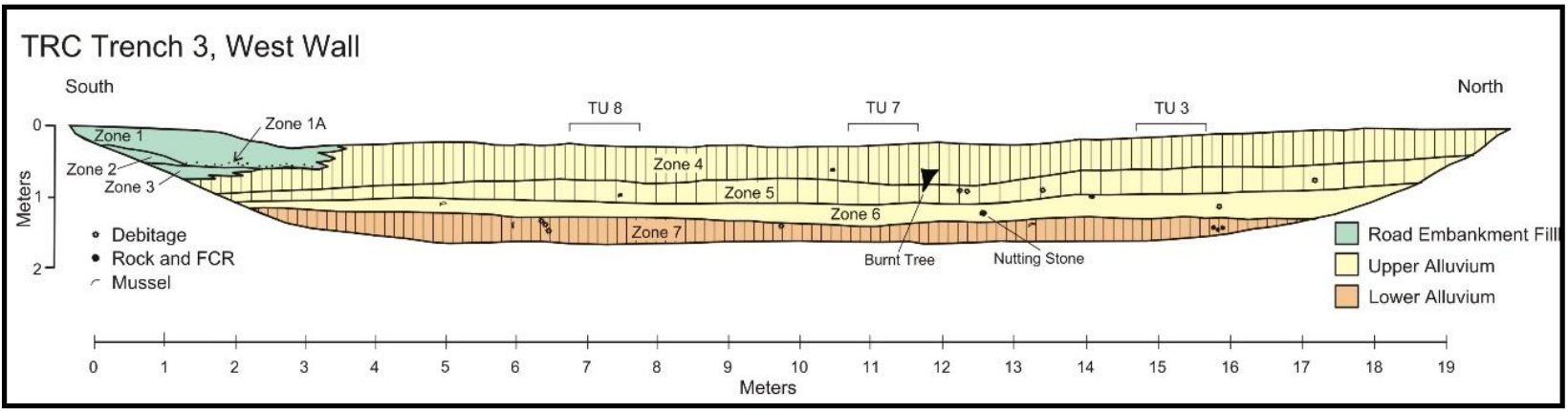

Figure 5-5. Drawing of the deposits exposed on the west wall of TRC Trench 3.

\section{TxDOT Trench 7, East Wall}

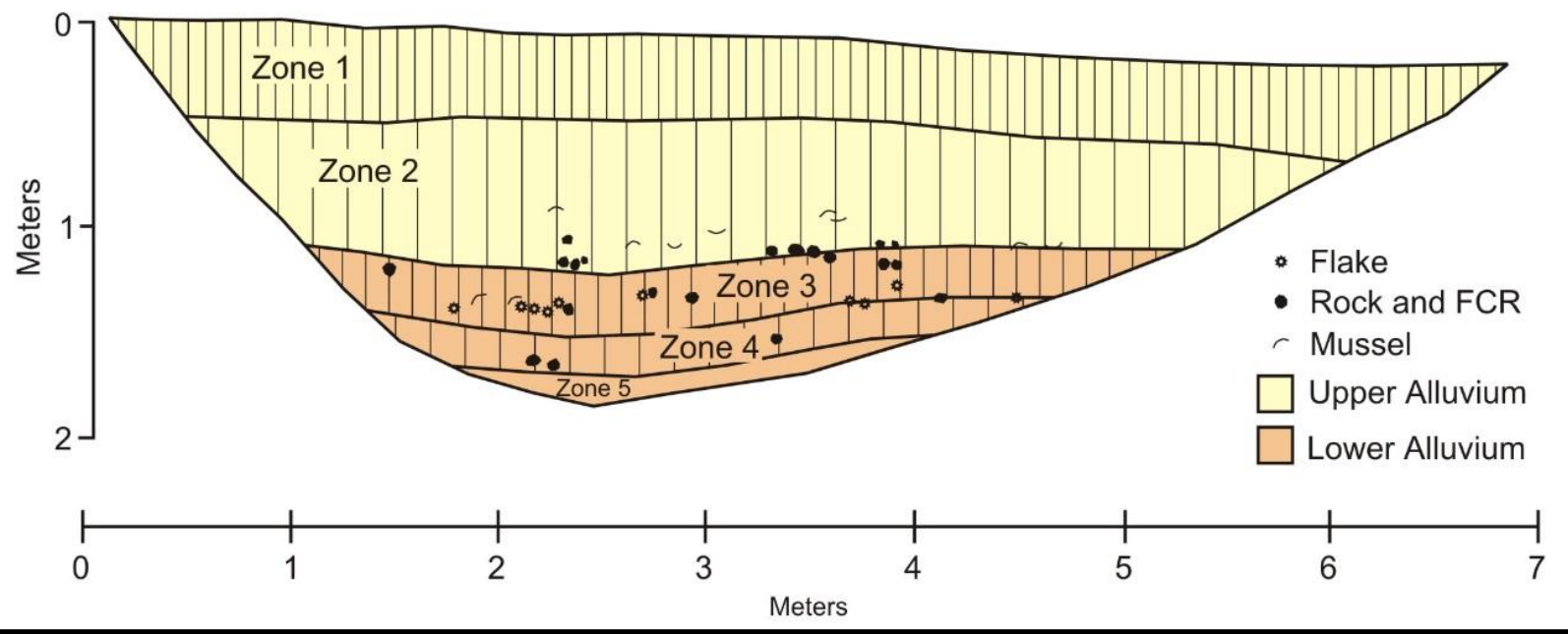

Figure 5-6. Drawing of the deposits exposed on the east wall of TxDOT Trench 7.

The increase in the A horizon thickness from north to south across the site implies that the land on the southern side of the site was either topographically lower or experienced more effective moisture that resulted in more luxuriant plant growth that led to an A horizon with more apparent organic enrichment. The modern ground surface slopes slightly to the north but this trend is very subtle. On the basis of the degree of soil development this deposit is interpreted to be of late Holocene age, and is tentatively correlated with the upper West Range alluvium at Foot Hood (Nordt 1992), which was radiocarbon dated to the period between approximately 2300 and 600 years B.P. Both BT 3 and TxDOT Trench 7 exhibited a small amount of cultural material near the base of the Upper Alluvium, and the stratigraphic occurrence of this material suggests that they represent more than one occupation (see Figures 5-5 and 5-6). These occupations are expected to be of Late Archaic age.

\subsubsection{The Lower Alluvium}

Beneath the Upper Alluvium was an older deposit that exhibited an Ak-ABk-Bk soil profile, but most trenches only exposed the Ak horizon of this unit. This Ak horizon consists of clay to silty clay that ranged considerably in color from black-very dark gray (10YR 2.5/1) to dark grayish brown (10YR 
4/2) and was not always immediately recognizable in variable lighting. It typically exhibited strong prismatic structure that broke down into strong subangular blocky structure, and contains calcium carbonate filaments (between as few as 1 to 2 percent to as many as 5 to 7 percent).

The deepest exposure at the site, the reopened TxDOT Trench 7 (at $\sim 1.8 \mathrm{~m}$ ) revealed the Ak horizon to be underlain by a transitional very dark gray (10YR 3.5/1) to brown (10YR 4/3) ABk horizon that gave way to a much less melanized and distinctly more brown (10YR 4.5/3) Bk horizon. Both latter horizons exhibited similar structure and calcium carbonate development to the A horizon.

A suite of 13 radiocarbon ages were obtained from the Lower Alluvium, and these assays place deposition of this alluvium in the late Holocene between 5100 and 2500 years B.P. (see Figure 5-3 lower panel; Figure 5-7 upper panel). The radiocarbon ages mostly consisted of pairs of bulk sediment dates and groups of Rabdotus snail shells collected from the same approximate depth, and the results show a remarkable amount of scatter for such a limited area. This scatter is most apparent for the eight samples (four pairs) that were collected between 130 and $140 \mathrm{~cm}$ below the ground surface, where 1,500 years separates the youngest and oldest snail dates. The sediment samples from this depth show slightly less scatter, with 670 years separating the oldest and youngest samples. A single bulk sediment sample was collected from the Bk the Upper Alluvium, no evidence of bedding or sedimentary structures was observed within the Lower Alluvium. The age, color and general appearance of this deposit are reminiscent of the lower West Range alluvium at horizon at about 1.8 $m$ depth in TxDOT Trench 7 and this sample yielded an age of 5100 years B.P.

Like Fort Hood (Nordt 1992), but the radiocarbon ages obtained from the deposits suggest that if this deposit is lower West Range alluvium, then this deposit is relatively thin here and may represent a drape over an older unit. Both BT 3 and TxDOT Trench 7 exhibited cultural material within the Lower Alluvium, and based on the depth of this material there appear to be at least two occupations present within this deposit, one within the buried Akb horizon, and a second below that in the ABk$\mathrm{Bk}$ horizons. If the age estimate for this deposit is correct, then the prehistoric deposits within the Lower Alluvium are most likely of Late Archaic age.

\subsubsection{Road Embankment Fill}

At the southern end of BT 3 (specifically two southernmost meters) the ground surfaces rises about $20 \mathrm{~cm}$ and this increase in elevation represents the northern side of a road embankment (see Figures 5-5 and 5-1). This road is oriented perpendicular to the farm-to-market road and extends off to the west of the highway ROW. A suite of sedimentary deposits were observed beneath and slightly to the north of the embankment (Zones 1 to 3 of BT 3) and these deposits were interpreted as earthen fill used to make the road. Judging by the depth of these artificial fills, the ground surface was first excavated about $20 \mathrm{~cm}$ before fill earth was added. The earthen deposits comprising the road are very similar in color and texture to the Upper Alluvium and most likely were derived from this deposit (specifically these deposits ranged from black to very dark gray (10YR $3 / 1.5$ ) clay, to very dark gray to dark grayish brown (10YR $3 / 1$ to $4 / 2$ ) silty clay and very dark gray (10YR 3/1, m) sandy clay).

\subsection{DISCUSSION}

Two natural alluvial deposits were identified within the trench excavations at 41MM382, and although these deposits exhibited a similar stratigraphic sequence, the variations in the deposits were very subtle. A simple shift in lighting could play havoc with recognizing the A horizon of the Lower Alluvium, but in diffuse light of the early morning the differences were generally quite apparent. All 


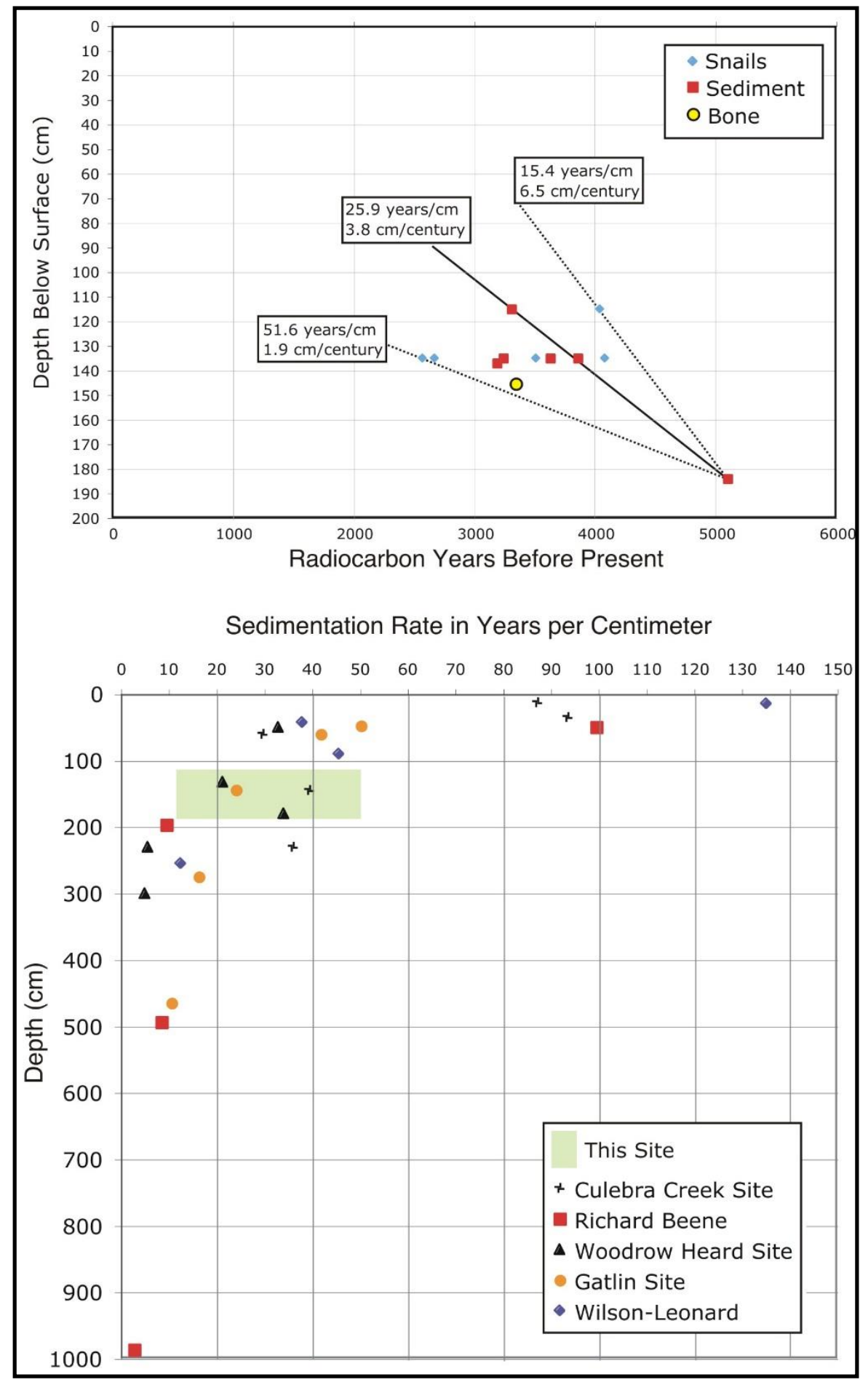

Figure 5-7. Upper Panel: Plot of the radiocarbon ages by depth and superimposed with lines showing the estimated sedimentation rates. The dotted lines showing the minimum and maximum sedimentation rates and the solid line is the central tendency rate calculated from the bulk sediment ages.

Lower Panel: Bivariate chart showing the calculated sedimentation rate plotted against depth below surface for several central Texas alluvial archeological sites. The green shading is the range of sedimentation rates calculated for this site. 
natural sediments exposed during testing were deposited in a flood basin setting and there is little variation in the depositional process apparent in these exposures, and in particular, there is no evidence of large magnitude flooding within these deposits.

Samples from two exposures (BT 1 on the north side of the site and TxDOT Trench 7) were collected and examined for particle size distribution and magnetic susceptibility, in order to test the idea that the A horizon at the top of the Upper Alluvium is indeed a soil and not merely a finer-textured sediment (shown in graphic form on Figure 5-4). The laboratory results demonstrate little textural variation is present, with all of the sediment samples reflecting a silt loam, and with mean particle size values between 6 and 7 phi (medium silt). Both profiles show a slightly coarser (sandier) section in the upper half of the Upper Alluvium (ca. 30 to $40 \mathrm{~cm}$ ) and the A horizon of this deposit exhibits little to no significant magnetic susceptibility enhancement. The A horizon at the top of the Lower Alluvium is slightly coarser textured than the overlying Upper Alluvium in BT 1, yet in TxDOT Trench 7 this deposit is slightly finer than the overlying Upper Alluvium and coarser than the underlying ABk horizon. Hence no consistent trend is present. Both profiles show a peak in the low frequency mass corrected magnetic susceptibility (Xlf) in the lower half of the Lower Alluvium A horizon. However, this peak neither matches the melanization of the soil horizon (as would be expected for pedogenic enhancement) nor the depth distribution of the cultural material (as one might expect for a prominent occupation surface), hence the results, although apparently correlative, are not clearly attributable to source. A more direct approach would be to assay the deposits for organic carbon, but this could not be done in the budget available for this phase of work.

\subsubsection{Context of the Cultural Deposits}

Prehistoric cultural material was observed near the base of the Upper Alluvium and with the Lower Alluvium, and the depth distribution observed within TxDOT Trench 7 indicates that the prehistoric occupations extend below the base of our test excavations. Multiple occupation surfaces appear to be present, and based on the radiocarbon ages obtained, these occupations most likely date from around 5000 to 2000 years B.P.

\subsubsection{Stratigraphic Integrity}

The stratigraphic integrity of the site considers two attributes of the deposits: the sedimentation rate and the degree of postdepositional disturbance (TxDOT Archeology Staff 2008). The sedimentation rate, in concert with cultural factors such as the rate of revisitation/occupation, controls the degree to which occupations of different age are separable or comingled. Postdepositional disturbance processes are capable of rendering sedimentary deposits with stratified, isolable occupations uninterpretable by mixing together different age deposits. Assessing these two attributes permit the assessment of the archeological potential of the site deposits.

A range of sedimentation rates can be calculated from the available radiocarbon ages, but the spread in the ages of dates obtained from one approximate depth, together with a single lower date impose some limitations on these estimates (see the upper panel on Figure 5-7), which shows the age-depth relationships for the radiocarbon ages, and minimum, maximum and an approximate central tendency for the site sedimentation rate; see also Table 5-2). In general terms, the section of the deposits where cultural materials have been observed most likely experienced sedimentation rates between about 2 and $7 \mathrm{~cm}$ of sediment per century. The central tendency rate estimate uses entirely bulk sediment radiocarbon ages and this data set appears to be somewhat more consistent than the radiocarbon ages obtained from the snail 
Table 5-2. Range of Probable Sedimentation Rates Within the Strata Bearing Prehistoric Occupations.

\begin{tabular}{|c|c|c|c|}
\hline Rate & $\begin{array}{c}\text { Years per } \\
\text { Centimeter }\end{array}$ & $\begin{array}{c}\text { Centimeters } \\
\text { per Year }\end{array}$ & $\begin{array}{c}\text { Centimeters } \\
\text { per Century }\end{array}$ \\
\hline High & 15.36 & 0.065 & 6.50 \\
\hline Central & 25.94 & 0.0385 & 3.85 \\
\hline Low & 51.63 & 0.0193 & 1.93 \\
\hline
\end{tabular}

shells. The minimum and maximum rates were calculated using the basal sediment age and the oldest and youngest snail ages. The probable rates, while not rapid, are reasonably fast, and consistent with the sedimentation rates observed at relatively shallow depths at other central Texas archeological sites such as Gatlin (41KR621), Woodrow Heard (41UV88), Wilson-Leonard (41WM235), Richard Beene (41BX831), and Culebra Creek (41BX126) (see lower panel of Figure 5-7). So from a sedimentation rate perspective, the occupations observed here are comparable to other sites excavated in the central Texas region in the recent past.

Assessing the degree of postdepositional disturbance is more subjective but equally important. Evidence of disturbed bedding or obvious burrows or krotovina is generally the types of features that contribute to this form of assessment. The massive deposits present at this site lack any form of stratigraphic marker beds, which can be an artifact of slow sedimentation or postdepositional disturbance. But there were no significant obvious evidence of large-scale postdepositional movement of the sedimentary matrix. Given the clayey nature of the deposits and the proximity of the site to the Blackland Prairie, it is also possible that shrink-swell processes may have altered the stratigraphic (and horizontal) integrity of the assemblage. Although a few pieces of cultural material were observed in vertical orientations, this form of evidence of shrink-swell behavior was uncommon. Somewhat surprisingly, although clayey, none of the soils observed at 41MM382 exhibited obvious vertic tendencies (in the form of pressure faces or slickensides), which suggests that the site deposits have not experienced significant adverse effects from shrink-swell phenomena. Overall, the stratigraphic integrity of this site is clearly in the range of the moderate category on Table 1 of TxDOT Archeology Staff (2008), or perhaps slightly higher (low end of the high category).

\subsubsection{Spatial Integrity}

Although the geoarcheological data did not provide much information on the spatial integrity of the deposits, from a theoretical perspective, the presence of the site in a flood basin setting where the site was inundated by overbank flows incapable of depositing sand or gravel suggests that the spatial patterning of the occupational debris should be quite high.

\subsubsection{Perishable Material Preservation Integrity}

The general impression obtained from the fieldwork is that the preservation of perishable material is generally low. Although no microfauna was noted in the field, the deposits at this site bear a strong resemblance to the Pilot Point alluvium on the Trinity River in north Texas, which often preserves such material. It would be worthwhile to perform a feasibility study to assess the potential for the preservation of such material if additional work is done at the site.

\subsection{REGIONAL IMPLICATIONS}

Stratigraphic work on the San Gabriel River in general, and streams traversing the Blackland Prairie in particular, are rare (cf. Abbott 2003; Frederick 2011) or relatively uninformative (e.g., Hall 1982a). Presumably, the chronology of these deposits will resemble that documented at the Siren site (41WM1126) on the South Fork of the San 
Gabriel River (see Carpenter et al. 2012; Frederick 2012), but at this time several clear differences are apparent. Three main deposits have been documented at the Siren site: 1) early to middle Holocene (not well-dated); 2) a middle to late Holocene deposit ( 4500 to 1000 years B.P.); and 3 ) a less than 1,000-year old deposit. The first excavations at the Siren site focused on occupations within the middle to late Holocene deposit (cf. Carpenter et al. 2012; Frederick 2012), whereas the most recent excavations examined the youngest deposit (Frederick 2012).

The main deposit exposed at the Barrett site is of middle to late Holocene age (ca. 5000 to 2000 B.P.) and appears to be of similar age to the middle to late Holocene deposit at the Siren site and is tentatively correlated with the upper and lower West Range alluvium at Fort Hood (Nordt 1992). But at the Siren site only a single deposit dating to the middle to late Holocene was present (equivalent to West Range, undivided). The base of that alluvial fill dated somewhere slightly older than 4500 years B.P. and the sedimentation rate within that deposit declined dramatically around 2500 years B.P., and the entire deposit was more than $5 \mathrm{~m}$ thick. The deposit observed at the Barrett site has a date of 5100 years B.P. a mere $1.8 \mathrm{~m}$ below the surface, which suggests that if this is the West Range alluvium, it is a relatively thin (ca. $2 \mathrm{~m}$ ?) drape across an older deposit. It should also be noted here that 5100 years B.P. is a bit old for the West Range alluvium in the Fort Hood region. So the chronological association of the alluvial deposit that hosts the prehistoric occupations is somewhat ill-defined at this time.

Furthermore, the transition from relatively narrow bedrock entrenched valleys in the hard limestones of the Edwards Plateau to broad meandering valleys on the much more erodible Cretaceous marls east of the Balcones Escarpment can be expected to lead to significant changes in the alluvial architecture, but few studies have examined this in detail. It would be an advancement to better understand the chronological structure of the San Gabriel River valley in proximity to the site.

\subsection{RECOMMENDATIONS}

Following examination of the testing phase results, three approaches are recommended for potential data recovery investigations: 1) establish the age and alluvial architecture of the deposits in proximity to the site; 2) collect samples for possible paleoenvironmental analysis; and 3) compile a more comprehensive collection of Uvalde gravels from the uplands. These approaches are elaborated on below.

\subsubsection{Establishment of Alluvial Architecture and Age}

The shallow trenches excavated during testing, together with the lack of a survey report significantly hindered understanding the stratigraphic context of the Barrett site, and it would be useful to better delineate the San Gabriel River deposits near this site so we have a better understanding next time such a crossing is surveyed. This work could be accomplished relatively expediently by means of a day or two with a GeoProbe corer followed by radiocarbon dating a suite of samples collected from the cores. The cores would not be logged in the field, but rather simply collected and then logged in the lab at a later date, at which time samples for dating and other various analyses would be extracted. This approach is similar to that employed by TxDOT on highway stream crossings elsewhere (e.g., Abbott 2003; but there are many other examples not cited here) and the results will provide a clear image of the deposits present and how the site fits into this stratigraphic landscape.

\subsubsection{Samples for Paleoenvironmental Analyses}

Although the general impression of the organic preservation potential of the site deposits is relatively low, data recovery excavations should collect and analyze a suite of samples that can be 
used to test to see if the deposits preserve microfossils and macrofossils that may yield a useful paleoenvironmental record. The period of time represented by these prehistoric occupations and depositional units is one that is relatively poorly documented across most of Texas. It would be useful to enhance our understanding of the paleoenvironment, if possible.

Specifically, four suites of samples are envisioned; 1) phytolith, 2) ostracod, 3) microfauna, and 3) snail. The fine-grained, low-energy depositional setting of the site may be ideal for preservation of a phytolith record, and as such it would be highly desirable to explore this in more detail. Likewise, microfossils that may provide details on the nature of water quality through time may also be preserved here. Based on previous experience, diatoms (fossil algae) will either not be present and/or reflect the edaphic environment and are not considered a likely source of information on water quality. Ostracods, silt to fine sand size calcareous aquatic crustaceans, may provide generalized information on past water quality as well as quantitative information by means of chemical analysis of their shells. Although there have been few studies of ostracods from Texas streams, microfossils of this size could easily have been deposited with overbank sediments. As noted previously, the finegrained nature of these deposits may also provide good preservation of microvertebrates and it would be worth examining a suite of samples from the site deposits to test this hypothesis. Finally, it would be worthwhile examining the molluscan assemblage to see if these fossils show any significant environmental changes in the late Holocene.

All of these proposed paleoenvironmental analyses should be approached as feasibility studies that are either: 1) sampled early in the excavations to test the ubiquity and diversity of the assemblages; and 2) then followed by detailed sampling toward the end of excavations if the feasibility samples prove fruitful; or 3) a suite of bulk soil samples should be excavated in order to carry out the feasibility samples postexcavation, and if any shown fruitful there is an adequate suite of column samples from which a more detailed analysis could be performed.

\subsubsection{Understanding Local Lithic Resources}

Finally, the Uvalde gravels that drape the uplands on either side of the San Gabriel River valley unquestionably provide a major source for retooling and also comprise one of the few local sources of rock of any kind in this immediate area. Examination of the river channel during testing demonstrated that point bars on this river would not necessarily provide a ready source of rock for prehistoric cooking purposes, and what was there was quite small. The uplands, on the other hand, although a bit further away, were capable of supplying a wide range of nonlimestone lithologies that are significantly different from the rock available in the stream channel, and may be distinctive from their geologic sources to the west owing to storage in alluvial sediments since transportation from their source area. Hence, sampling of both source areas in detail followed by detailed analysis (e.g., instrumental neutron activation analysis [INAA] or very near infrared reflectance spectroscopy [VNIRS] see below) of the two source areas and the cultural assemblages should permit a better understanding of local prehistoric resource exploitation.

Although analyses such as INAA have a potential to permit resolution of different raw material sources, this approach is both costly and slow. An attractive alternative is to test the application of a semiquantitative nondestructive analysis such as, very near infrared reflectance spectroscopy (VNIRS); sometimes referred to by a specific instrument, such as portable infrared mineral analyzer (PIMA) (Wisseman 2004) either alone or in conjunction with a relatively inexpensive quantitative method of chemical characterization (e.g. portable XRF or PXRF) (Shackley 2012). A combination of techniques is desirable. 
Such instruments operate in the mid to near infrared wavelength region from about 1300 to $2500 \mathrm{~nm}$ and measure spectral responses from a sample area of about $10 \mathrm{~mm} \times 2 \mathrm{~mm}$. VNIRS has the potential to discriminate between source materials for rocks like chert as well as other mineralic substances (like pottery) and is relatively rapid and can be nondestructive. Parish (2009) provides one example of this method applied to chert sourcing and noted that it was reasonably fast and accurate. Application of a method such as a test to see: 1) if it is capable of distinguishing between meaningful geological contexts that hold behavioral implication (such as separating the Uvalde cherts from either bedrock and/or recent alluvial gravel derived cherts); and 2) if so, apply the method to the prehistoric lithic assemblage in order to better understand resource use and exploitation. Were the inhabitants of this site coming from nonlithic source areas (i.e., from the east or northeast) and using the Uvalde sources, or were the tool stones here derived from bedrock sources to the west? Finding a cost efficient analytical method that might permit us to see such ancient behavior could have widespread applications elsewhere in the state. 


\subsection{ARCHEOLOGICAL RESULTS}

J. Michael Quigg and Paul M. Matchen

\section{$6.1 \quad$ INTRODUCTION}

The Barrett site, as defined by TxDOT archeologists, is a small buried prehistoric site. Cultural materials are buried from roughly $50 \mathrm{cmbs}$ to at least $160 \mathrm{cmbs}$ in alluvium along the San Gabriel River, a stream that crosses the Blackland Prairie region from west to east in central Texas. The excavation of four backhoe trenches (BT 1 through BT 3, and TxDOT Trench 7) totaled roughly 42 linear meters across the APE and provided windows from which nine 1-by- $0.5 \mathrm{~m}$ test units were hand-excavated in $10 \mathrm{~cm}$ arbitrary levels from the sides of the backhoe trenches to explore the top ca. $150 \mathrm{~cm}$ of the alluvium. These $11.4 \mathrm{~m}^{3}$ hand-excavations provided horizontal coverage of the $58 \mathrm{~m}$ long by $8 \mathrm{~m}$ wide ape/target area to permit discussions of horizontal and vertical distribution of the cultural materials and make recommendations as to the site's eligibility for listing on the NRHP and as a SAL.

The following section first addresses the vertical distribution of the cultural remains recovered from the hand-excavations, specifically taking into account quantities of lithic debitage, burned rocks, and mussel shells, the three most abundant classes of cultural debris. The vertical distribution of these materials will be discussed as the basis for defining the number of cultural zones or components within the site's alluvial deposits. Once the zones/components are identified, the material remains from those components are described and discussed. Following the data presentation, we offer a general discussion of the findings.

\subsection{CULTURAL STRATIGRAPHY}

It is not clear from observations of the natural stratigraphy, whether or not the upper $30 \mathrm{~cm}$ or so had been significantly altered from modern land clearing and/or cultivation. Observations of the site's present surroundings, with its groves of pecan trees and underlying grasses plus adjacent agricultural fields, do indicate, however, that the upper deposits have likely been disrupted within the last 150 years. Additionally, a few large/mature pecan and elm trees are on-site and have extensive root systems that have likely pushed and moved at least some of the smaller cultural items within the deposits. On the other hand, the hardness of the clayey deposits has likely prevented any significant rodent activity, an inference that appears to be supported by the lack of observable krotovinas or burrows in the deposits.

Geoarcheologists Charles Frederick and Brittney Gregory examined all four opened backhoe trenches and documented the natural stratigraphy (see Chapter 5.0). Although boundaries between soil horizons and buried soils were vague at best (Figure 6-1), Frederick was able to identify a general A, AB, ABk, Bw soil horizon sequence. An ABk soil zone was identified roughly between 100 and $145 \mathrm{cmbs}$ in most trenches. This upper boundary of this slightly darker zone (10YR 3/1.5 to 2.5) varies slightly in depth, from $100 \mathrm{cmbs}$ in BT 1 to $110 \mathrm{cmbs}$ in TxDOT Trench 7. This is one of two alluvial units (see Chapter 5.0 for details). This one slightly darker $\mathrm{ABk}$ horizon provides a horizontal marker in the deposits and indicates relatively limited horizontal change across the area investigated.

The TUs were hand-excavated across the site off the sides of the various trenches (Figure 6-2). At the northern end of the site and the APE, TUs 1 and 5 were at BT 1 . About $12 \mathrm{~m}$ south, TUs 2 and 6 were next to BT 2. Test Units, 3, 4, 7, and 8 were excavated along BT 3 , still farther south. Test Unit 9 was the only unit in TxDOT Trench 7 towards the southern end and on the western margin, some 19 $m$ south of BT 2. The cultural stratigraphy is, therefore, discussed according to observations made in each of these groups of hand-dug test units. 


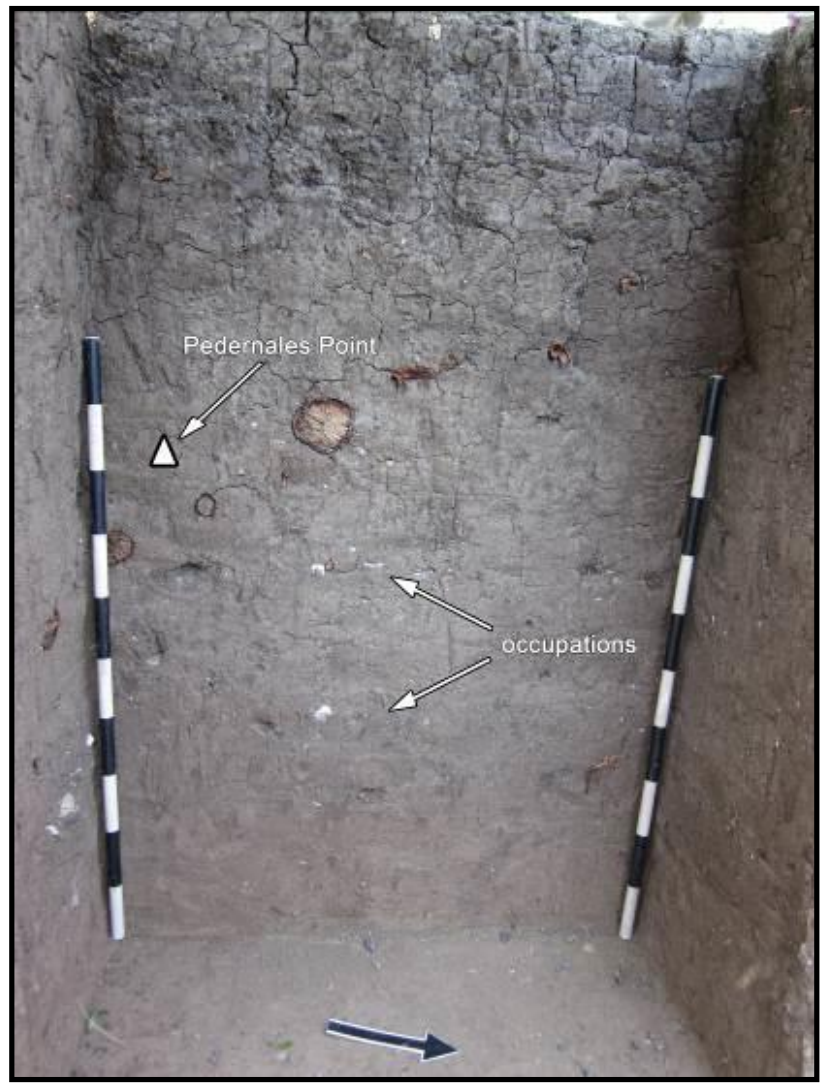

Figure 6-1. Profile of west wall of Test Unit 9 showing two dense zones of occupational debris, one at ca. $112 \mathrm{cmbs}$ and another at 130 cmbs of TxDOT Trench 7.

At the northern end of the investigated area, the vertical distribution of the materials in TUs 1 and 5 are similar, showing a discernible peak in frequency between roughly 130 and $160 \mathrm{cmbs}$ (Figures 6-3 and 6-4). Unit 1 contained extremely sparse cultural material in the top $50 \mathrm{~cm}$, therefore the handexcavated sediment from the top $50 \mathrm{~cm}$ of TU 5 was discarded without screening. A limited number of artifacts were collected from 50 to about $130 \mathrm{cmbs}$ in both units. A nearly void zone was found between 90 and $100 \mathrm{cmbs}$ that contained a few burned rocks and couple of mussel shells, but no lithic debitage. A dramatic increase in burned rocks and mussel shells combined with moderate increases in lithic debitage was encountered between about 130 and $160 \mathrm{cmbs}$ in both units. These materials represent at least one occupation zone in the lower part of both units. At least two other occupation zones may be represented above $130 \mathrm{cmbs}$, although they are represented by much less material and are more difficult to distinguish vertically.

Adjacent TUs 2 and 6, also in the northern end of the investigated area at BT 2, revealed a similar vertical distribution of cultural material as detected in TUs 1 and 5, and in somewhat higher frequencies (Figures 6-5 and 6-6). Again the top $50 \mathrm{~cm}$ of TU 2 was nearly devoid of cultural materials and therefore, the sediment in the top $50 \mathrm{~cm}$ of TU 6 was discarded without screening. Here, the highest density of cultural materials, mostly lithic debitage and burned rocks, was again between 130 and 160 cmbs in both units. Test Unit 2 revealed a minor peak of burned rocks between 70 and $90 \mathrm{cmbs}$ and another minor peak of mostly lithic debitage between 110 and 130 cmbs. Consequently, three peaks in density are recognized. The upper two yielded considerably less material than the lowest one. This lower peak equates to the lower peak in BT 1. The two higher peaks in TUs 2 and 6 are interpreted to represent at least two additional, isolable cultural components.

Trench 3 in the southeastern corner of the targeted area, along with the four adjacent TUs, reveal variable peaks in the vertical distributions of the three dominate classes of material (Figures 6-7, 68, 6-9, and 6-10). Starting at the northern end of BT 3 with TU 3, the following description concerns the hand-dug units, moving from north to south.

Test Unit 3 revealed a peak of debris (mostly lithic debitage) between 60 and $100 \mathrm{cmbs}$ and a second peak of debris (in this case mostly small mussel shell fragments) between 130 and $150 \mathrm{cmbs}$. Four meters to the south, TU 7 contained a moderate peak of lithic debitage and burned rocks between 80 and $90 \mathrm{cmbs}$, plus a second peak of material, that consisted of lithic debitage, mussel shells, and burned rocks between 100 and $110 \mathrm{cmbs}$. TU 8 was situated roughly $4 \mathrm{~m}$ farther south and yielded a major peak or zone of burned rocks and lithic 


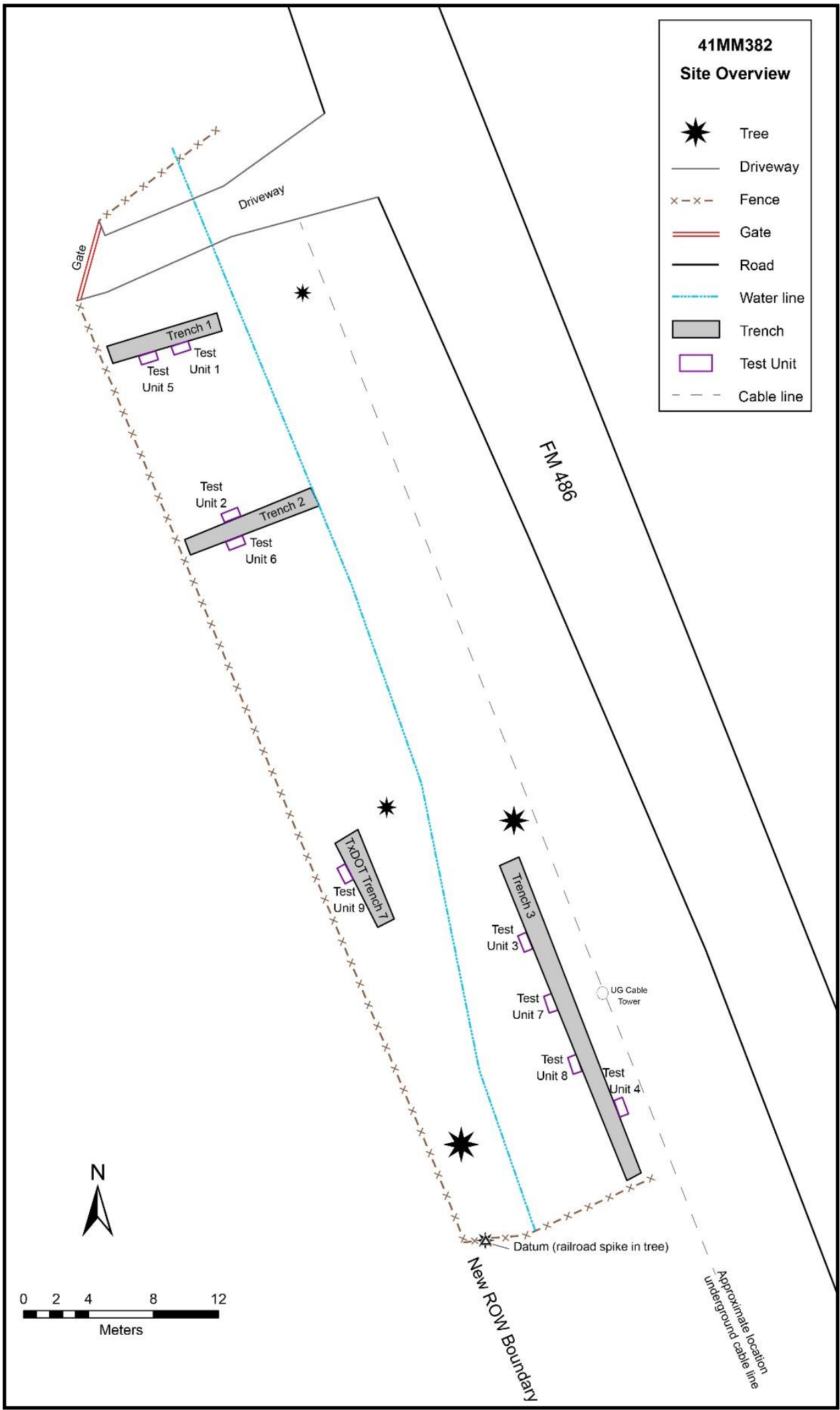

Figure 6-2. Barrett site showing distribution of backhoe trenches and test units. 


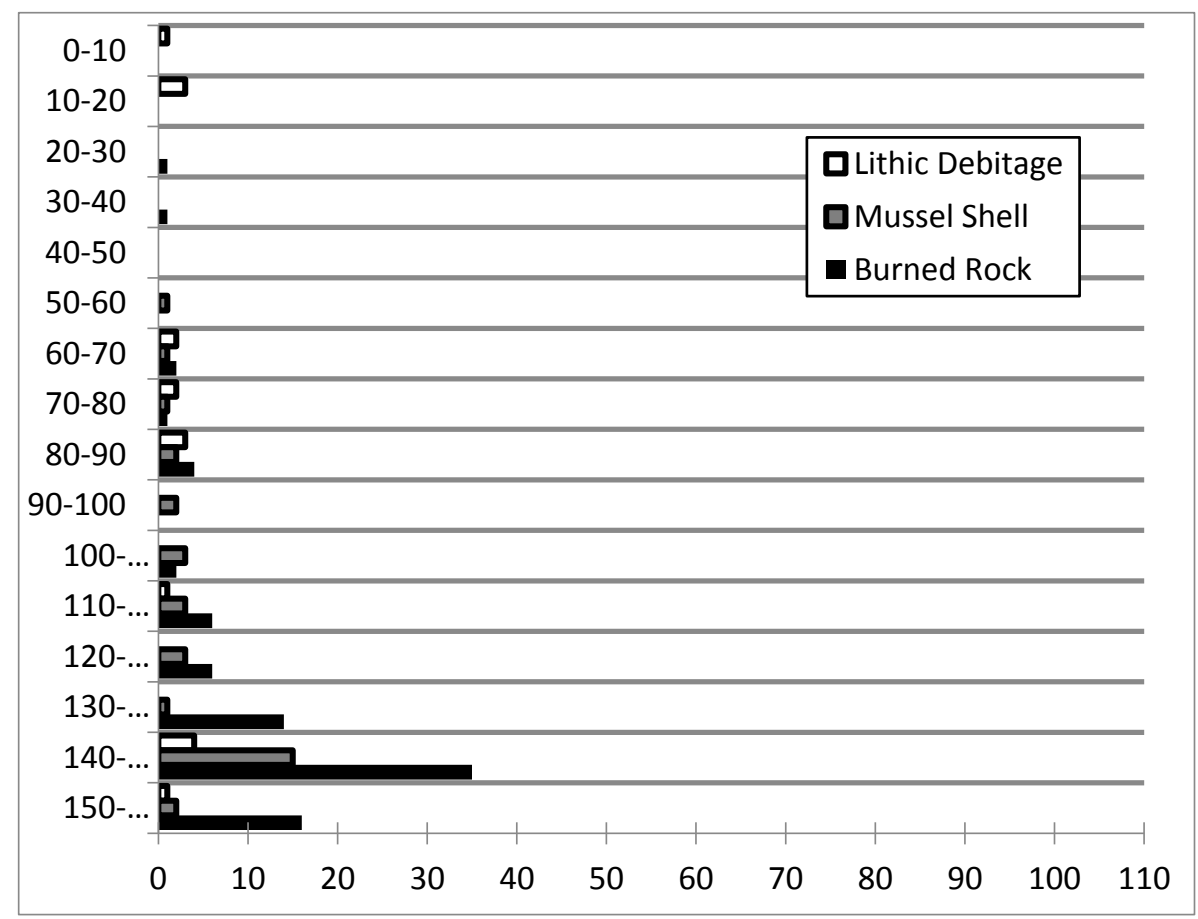

Figure 6-3. Vertical distribution of three classes of material from Test Unit 1 off Trench 1.

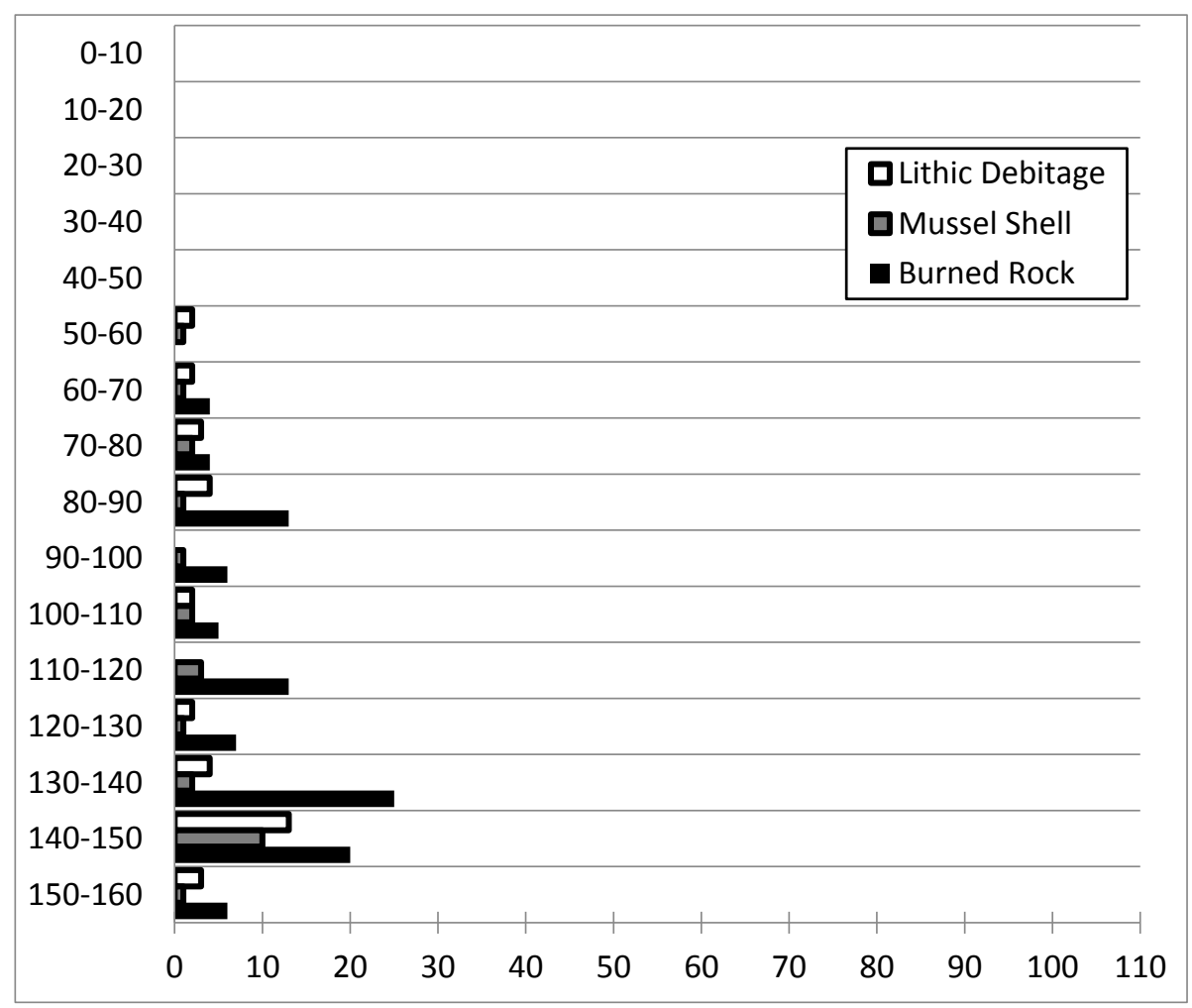

Figure 6-4. Vertical distribution of three classes of material from Test Unit 5 off Trench 1. 


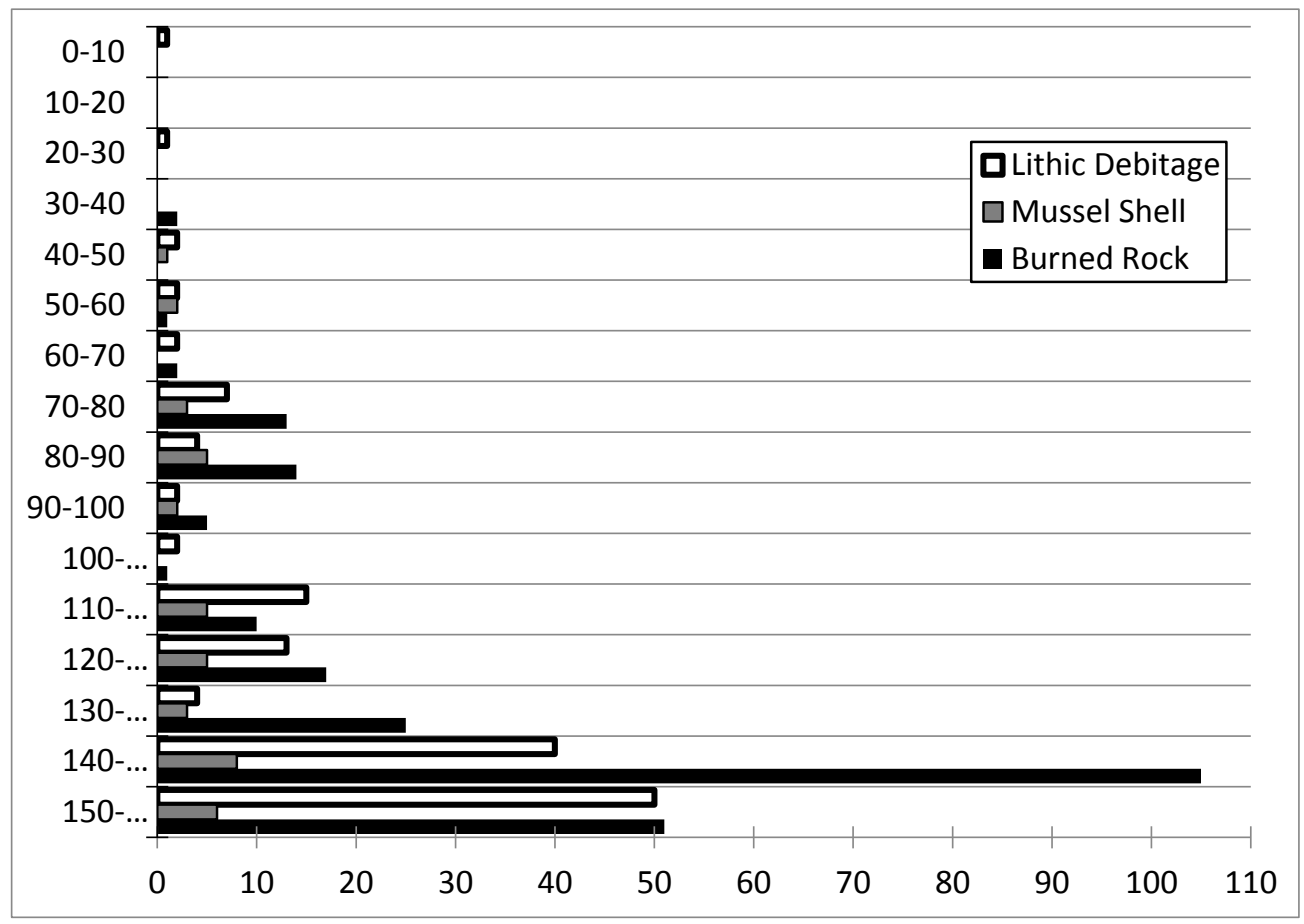

Figure 6-5. Vertical distribution of three classes of material from Test Unit 2 off BT 1.

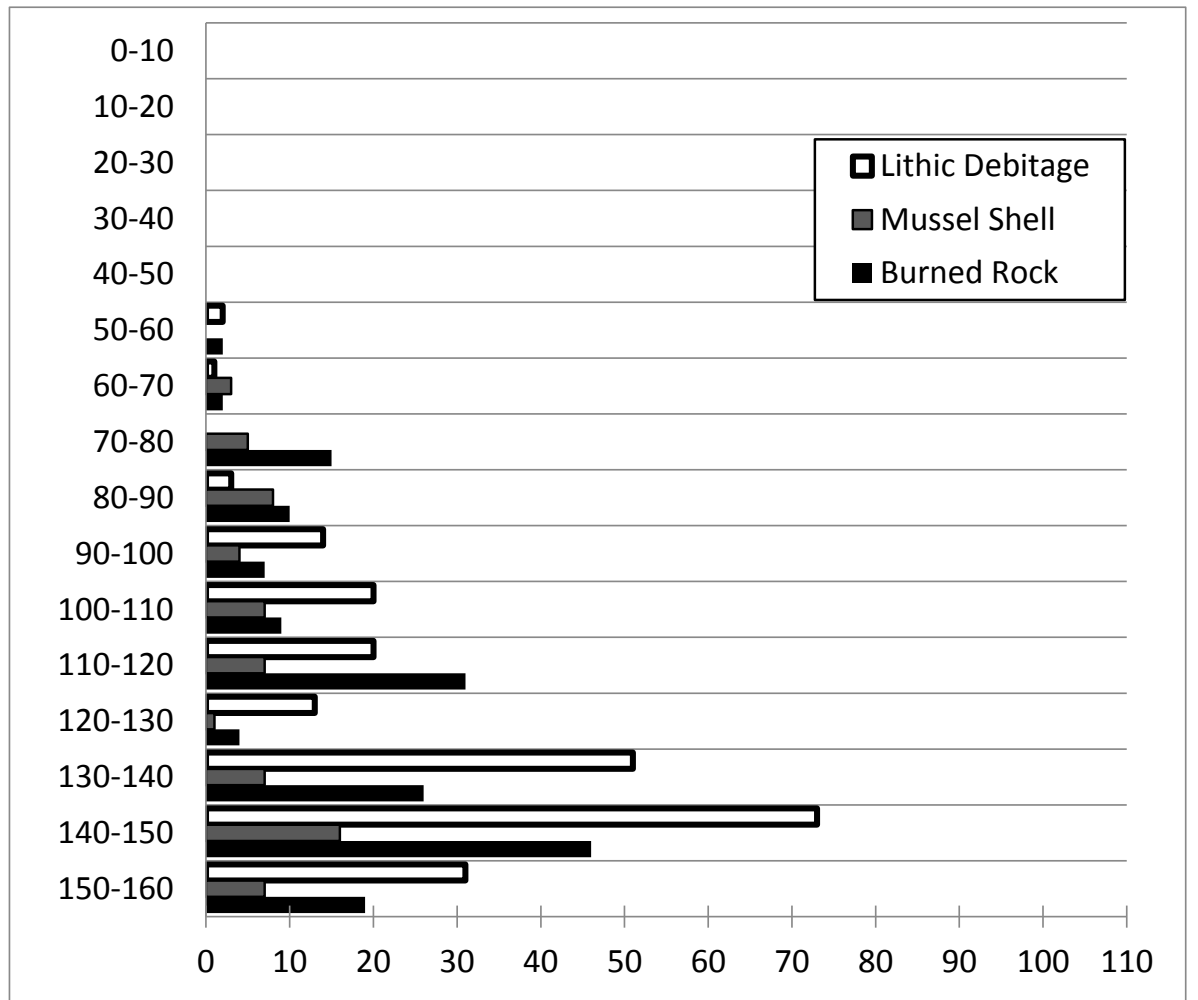

Figure 6-6. Vertical distribution of three classes of material from Test Unit 6 off BT 1. 


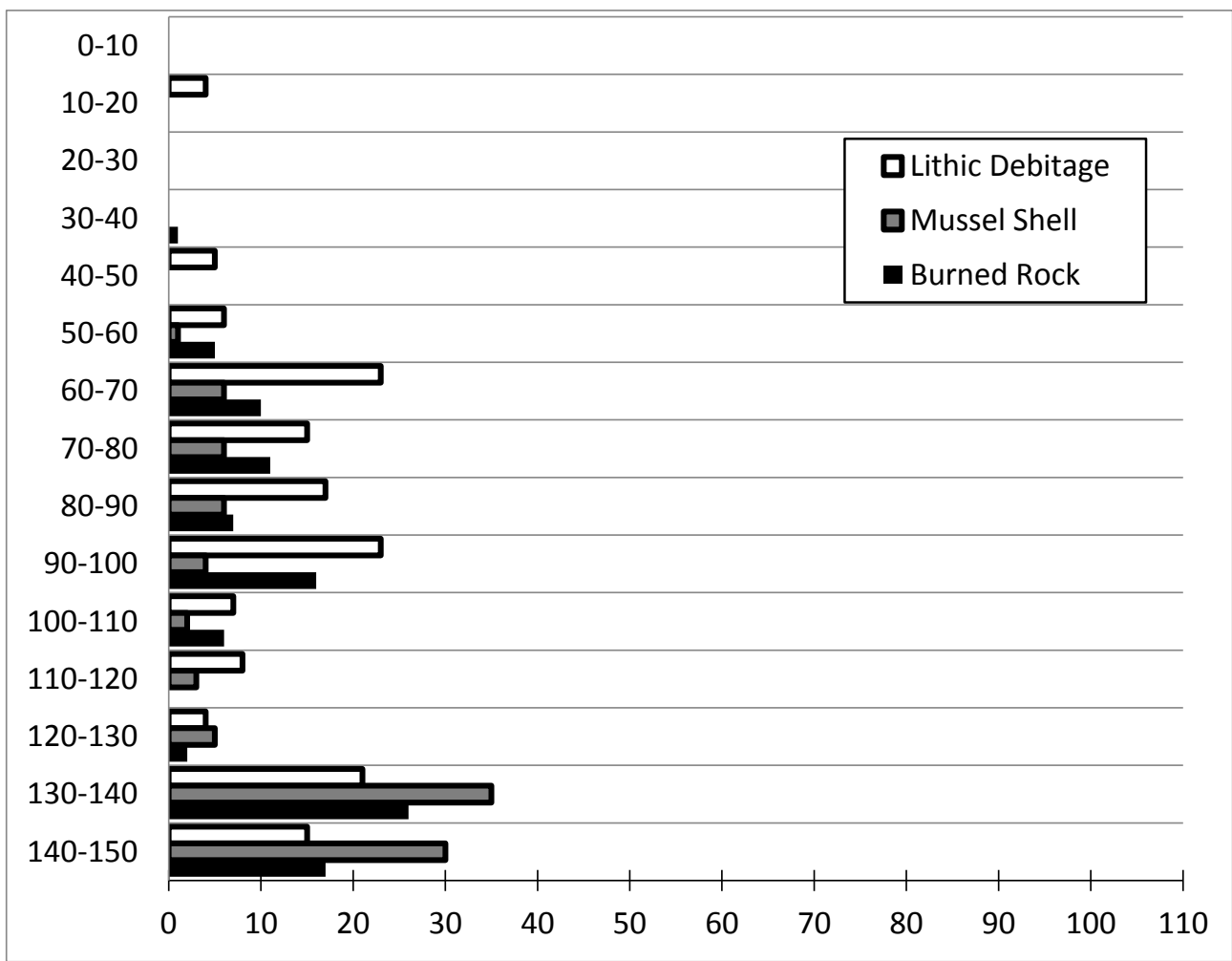

Figure 6-7. Vertical distribution of three classes of material from Test Unit 3 off BT 3.

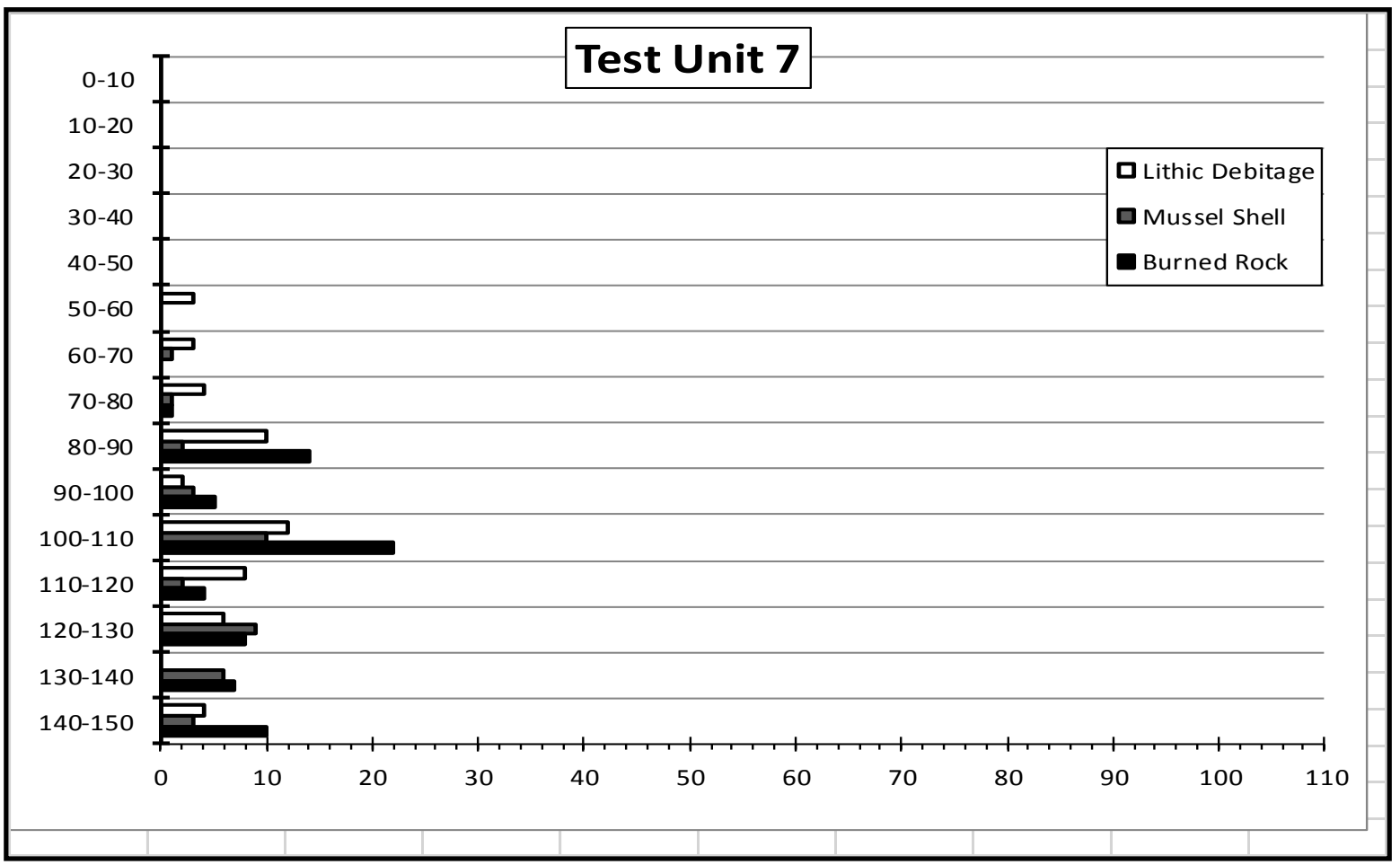

Figure 6-8. Vertical distribution of three classes of material from Test Unit 7 off BT 3. 


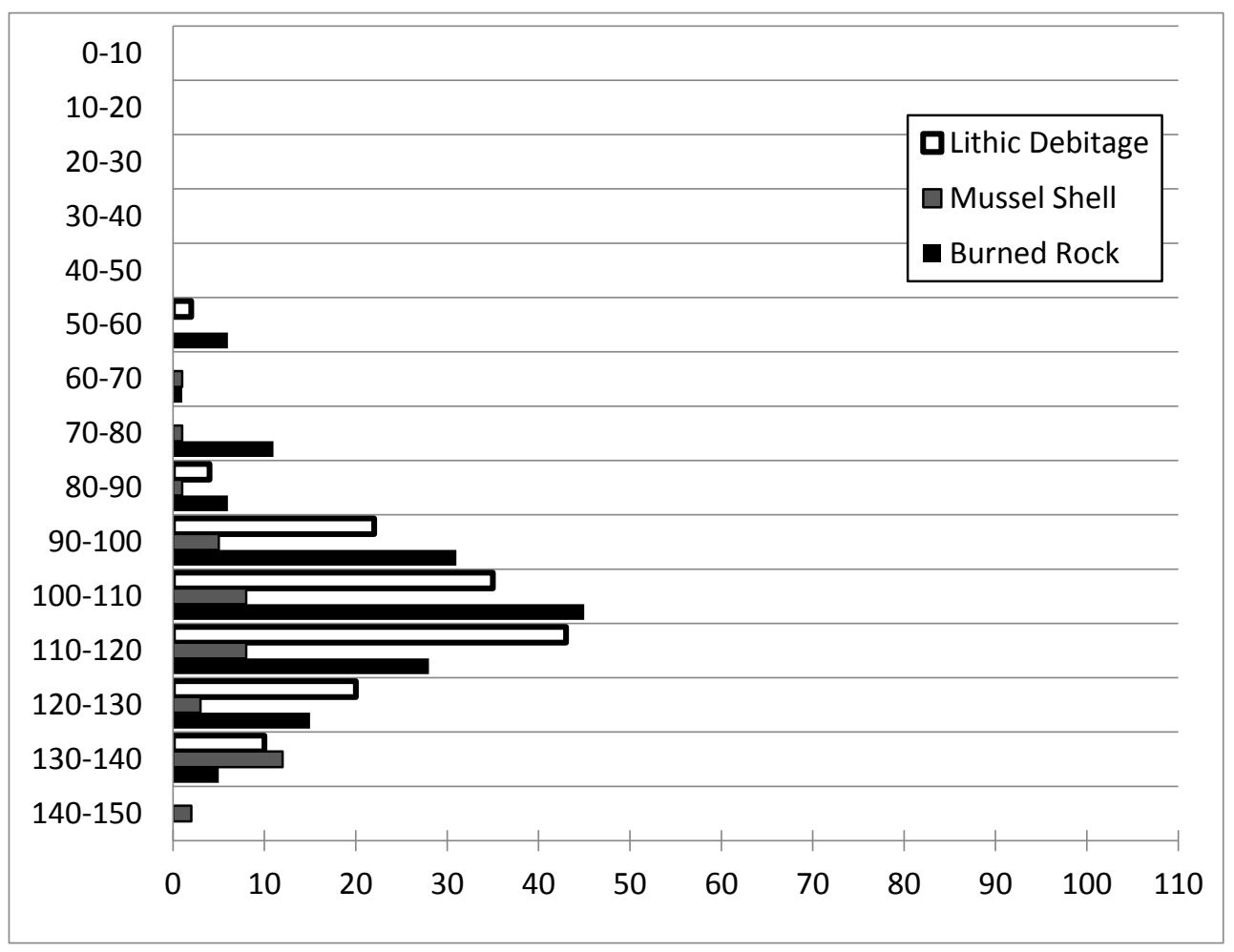

Figure 6-9. Vertical distribution of three classes of material from Test Unit 8 off BT 3.

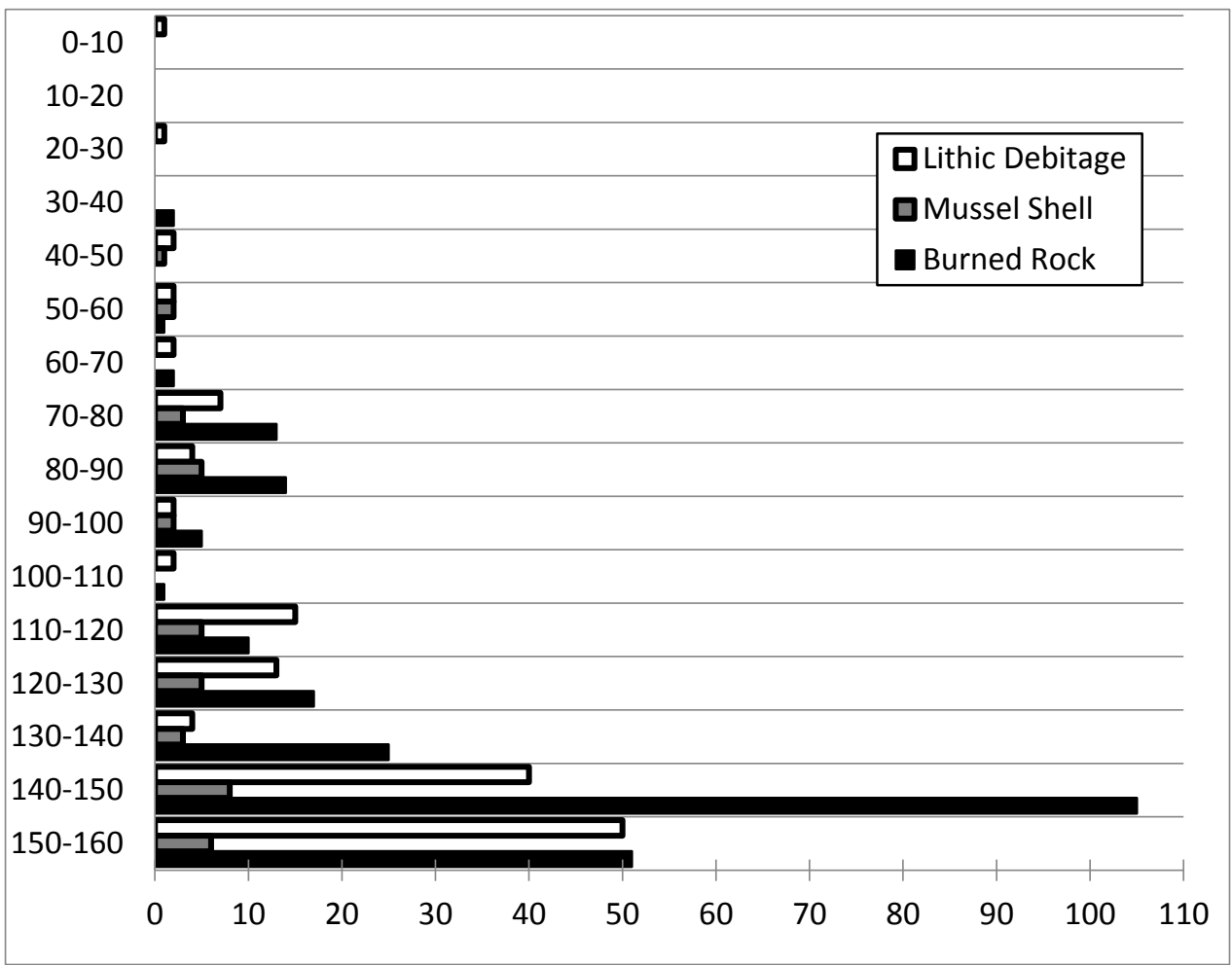

Figure 6-10. Vertical distribution of three classes of material from Test Unit 4 off BT 3. 


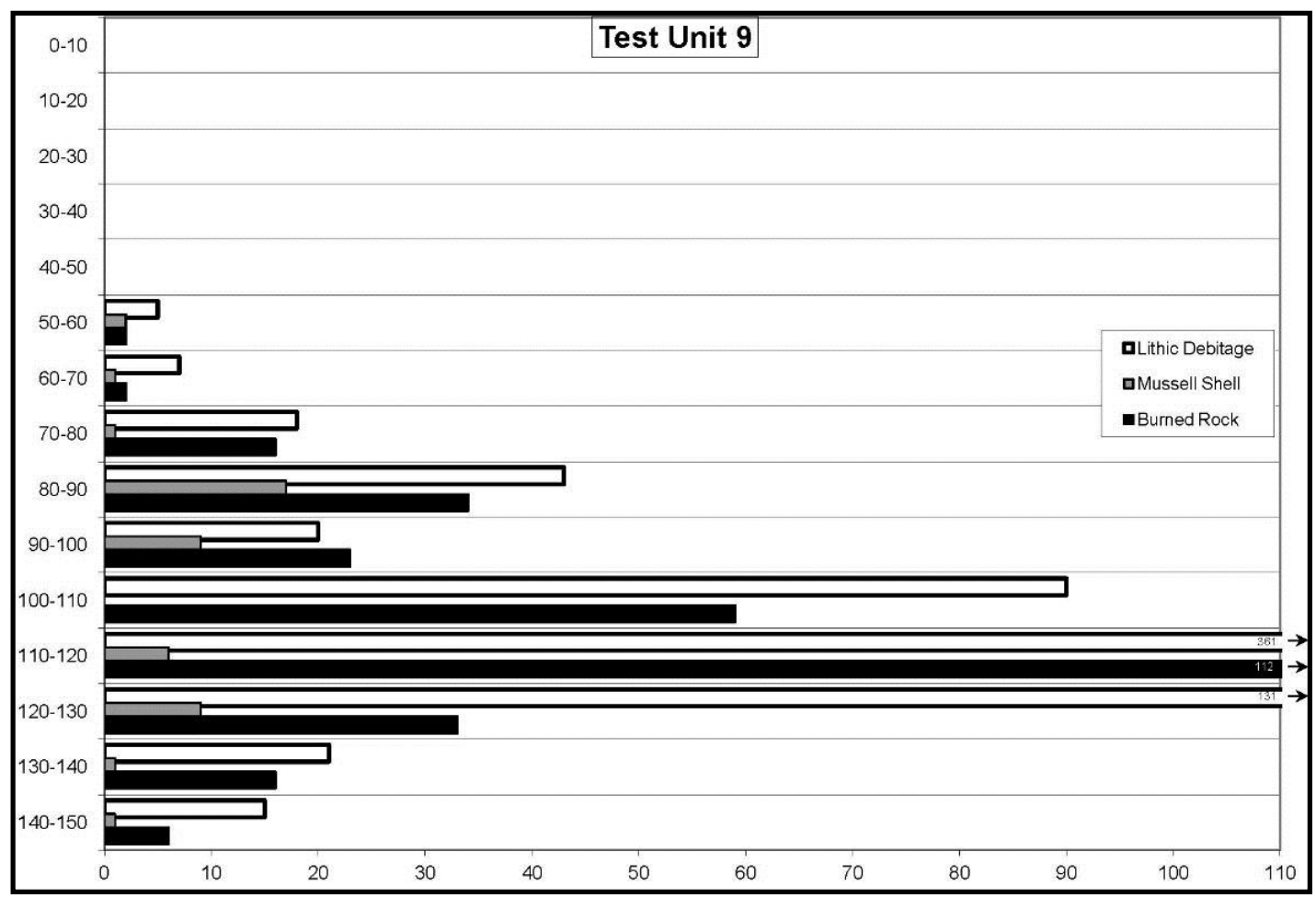

Figure 6-11. Vertical distribution of three classes of material from Test Unit 9 off TxDOT Trench 7.

debitage from 90 and $130 \mathrm{cmbs}$. Almost no cultural material, except for a few small burned rock fragments, was found between 50 and $90 \mathrm{cmbs}$. Below $130 \mathrm{cmbs}$ was a peak in mussel shells associated with a limited amount of lithic debitage. The southernmost unit, TU 4, revealed one minor peak of debitage between 110 and $130 \mathrm{cmbs}$ withanother minor peak of debitage first encountered at $130 \mathrm{cmbs}$. The top $100 \mathrm{~cm}$ of TU 4 yielded sparse and scattered lithic debitage and burned rocks, which were likely disturbed by an intrusive fence post with a concrete base along the eastern margin of the unit. The upper $50 \mathrm{~cm}$ or so of TU 4 also yielded recent pieces of glass, some historic whiteware ceramic fragments, and a small metal fragment, all indicative of disturbances. Roughly two meters south of TU 4 at the end of BT 3 was a nearly complete horse metapodial at 55 cmbs. This is likely indicative of disturbance of the upper levels at the very southern end of the site associated with the road bed. In general terms, three vertical peaks of cultural material were recognized in different parts of BT 3, but this trench revealed more variability between it and adjacent units. Nonetheless, the vertical positions of the three peaks generally correspond to peaks identified in the more northerly units.

TxDOT Trench 7, with TU 9 on its western side, revealed a modest peak of lithic debitage and burned rocks associated with some mussel shells between 80 and $90 \mathrm{cmbs}$. This was followed by a slight decrease in material between 90 and 100 cmbs. From roughly 100 to $130 \mathrm{cmbs}$ was a tremendous increase in lithic debitage and burned rocks plus a few mussel shells. These three levels indicate a zone of dense cultural debris between 70 and $100 \mathrm{cmbs}$. A major high density peak of lithic debitage was detected between 100 and $130 \mathrm{cmbs}$ along with moderate amounts of burned rocks and only a few mussel shells (Figure 6-11).

Cultural materials were still present below 130 cmbs, but in much lower frequencies. This general vertical patterning from the TU 9 is similar to that 
noted by TxDOT archeologists in their original inspection of this trench (see Chapter 1.0 and Figure 1-5).

Overall, the general results from the nine units showed some consistency in the vertical distribution across the area investigated. In most units, two or three peaks of cultural materials were detected. The two upper peaks yielded lower frequencies of debris/artifacts than did the much more prominent peak in the lowest levels of the excavations. Minor elevational differences are present in the vertical positions of each peak across the area, but these are expected given the excavations in $10 \mathrm{~cm}$ arbitrary levels and the horizontal distance of 40 to $50 \mathrm{~m}$ involved. The distribution of cultural materials across any given prehistoric campsite is very unlikely to have been uniform, and this appears to be represented here by the variable densities among the debris density peaks in the various units.

In sum, the cultural materials across the Barrett site exhibit three generally distinguishable peaks in their vertical density. The upper 50 to $60 \mathrm{~cm}$ of the initial four TUs (TUs 1 through 4) yielded very sparse or no cultural materials and does not appear to contain evidence of in situ occupation zone(s). Nearly all cultural materials and the three principal vertical density peaks lie between 60 and $160 \mathrm{cmbs}$ across the area investigated. It is apparent that at least three cultural peaks/zones occur in this lower $100 \mathrm{~cm}$ of alluvial deposits. The two upper peaks, at roughly 60 to $90 \mathrm{cmbs}$ and roughly 100 to 130 cmbs, depending on the particular unit, are detectable but have relatively low densities, except in TU 9 were an obvious high density locale was detected in the 100 to $130 \mathrm{cmbs}$ range. This high density locale also yielded a complete Morrill point at $115 \mathrm{cmbs}$ from the profile of TxDOT Trench 7 and the proximal end of another possible Morrill point from between 120 and $130 \mathrm{cmbs}$ in TU 9. Test Unit 9 also yielded the proximal half of a Pedernales point at $70 \mathrm{cmbs}$.

\subsubsection{Vertical Distribution by Peaks in Frequency}

Three peaks in debris density are definable at the Barrett site. From shallowest to deepest, these are as follows:

a. The uppermost peak of material frequency occurred roughly between 60 and $90 \mathrm{cmbs}$. This peak yielded one diagnostic projectile point, the proximal half of a Pedernales point (\#70-10) at $70 \mathrm{cmbs}$ in TU 9 (Figure 6-12). This peak is not well-defined in any one TU, but was noticeable as the consistent presence of cultural materials at this depth. No features were discovered within this depth range.

b. The middle peak of materials was roughly between 90 and $120 \mathrm{cmbs}$ (Figure 6-13). This zone yielded a patinated Morrill point (\#154-10) from $115 \mathrm{cmbs}$ from the exposed wall of TxDOT Trench 7 (Figure 6-14). Feature 3, a concentration of burned rocks and mussel shells between 110 and $112 \mathrm{cmbs}$ in TU 6 was at this same level. This was also the same elevation as burned rock Feature 4 on the opposite wall of TxDOT Trench 7, which would indicate that the Morrill point and Feature 4 were part of the same occupation zone. This peak in materials was most prominent in TUs 7, 8, and 9 towards the southern end of the site.

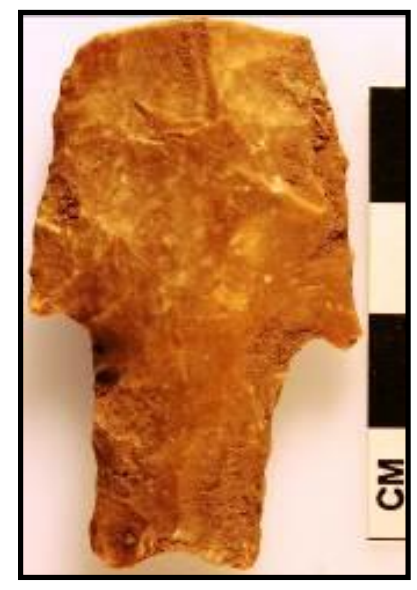

Figure 6-12. Proximal half of Pedernales projectile point (\#70-10) from $70 \mathrm{cmbs}$ in TU 9. 


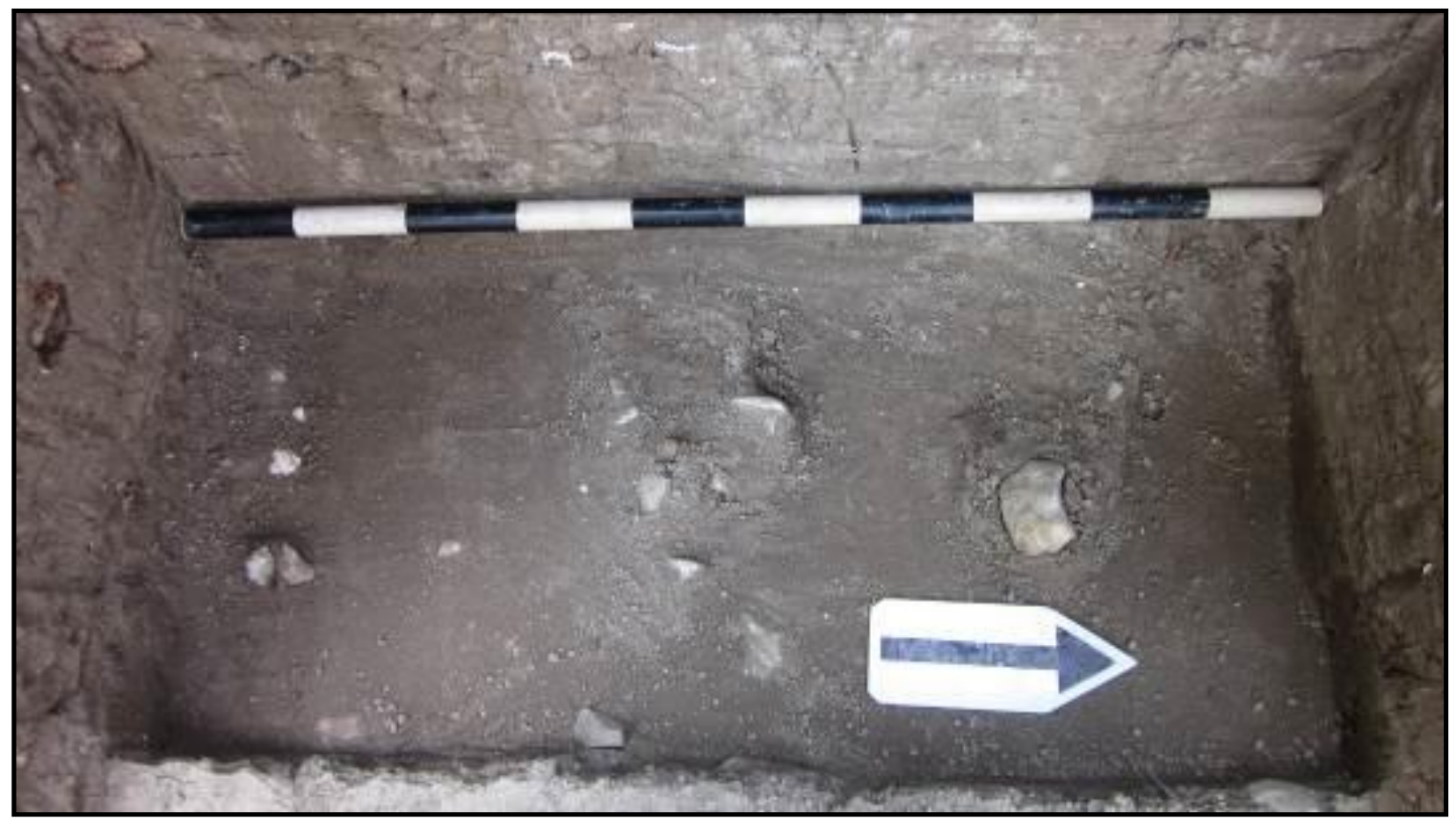

Figure 6-13. Plan view of cluster of cultural materials at ca. $112 \mathrm{cmbs}$ in Test Unit 9, second peak, off Backhoe Trench 7.

c. The lowest peak was generally below $120 \mathrm{cmbs}$ and was associated with a burned Morrill point (\#93-10) from 120 to $130 \mathrm{cmbs}$ in TU 9 (Figure 6-15). Features 1 and 2, with various kinds and quantities of cultural debris were both part of this lowest component and reflect the use of this zone. This peak was best defined in TUs 1 , 2, 3, 5 and 6 which, with the exception of TU 3 , were at the northern end of the site. This zone appears to be more widespread than the upper two zones.

\subsubsection{Radiocarbon Dates}

Cultural charcoal, except for the occasional fleck, was not recovered from any of the identified cultural features or occupation zones. Therefore, alternative material classes (i.e., Rabdotus and soil humates) that potentially contain organic residues from noncultural materials were submitted to obtain absolute dates. Since noncultural materials were targeted, the specific times of the cultural events are not identified and are only extrapolated from the derived results.
We selected 13 samples; 6 humate samples, 5 samples of multiple Rabdotus shells, and 2 tiny bone fragments for radiocarbon dating. Of the 13 samples collected, 12 returned radiocarbon ages. Under the direction and guidance of geoarcheologist Charles Frederick the six sediment samples were selected from across the investigated area to assess the general age of the deposits and gain area to assess the general age of the deposits and gain an understanding of the temporal correlations of the deposits encountered in the scattered profiles. In an attempt to complement and strengthen the overall understanding of the ages derived from the sediment humates, multiple Rabdotus snail shells from the same or similar proveniences as the humate samples were also selected and dated. It is assumed that; a) the Rabdotus shells were not heated or burned to result in anomalous carbon residues, and b) that shells from a single provenience were deposited at approximately the same time. The Rabdotus snail shells from this site in the Blackland Prairie have likely been feeding on the local vegetation. 
Therefore, there is no apparent need for a correction factor to be applied to the Rabdotus shell results as there would be for similar shell dates from central Texas with the limestone carbonates potentially contributing to yield older dates.

Direct dating of humates and Rabdotus snail shells have been accomplished previously across Texas with mixed results (see Frederick 2011 for comparisons and problems). Consequently, one must view these results as general ballpark dates rather than precisely defined points in time. Table 6-1 presents the provenience and results from the dated samples. The dates are presented in the pairs from respective proveniences and from shallowest to deepest. The paired samples of humates and shells reveal the differences between the two data sets. The humate dates are older in three of the five pairs, with one humate date younger, and one essentially the same as that obtained on the Rabdotus shells.

Two tiny bone fragments, unidentifiable as to species or anatomical element, were recovered in apparent cultural context. Both were submitted in anticipation of obtaining direct dates on cultural material. One tiny fragment (\#128) failed to provide sufficient carbon for dating. However, a fragment of an animal tooth (\#127) from what appeared to be the lowest cultural zone (140 to $150 \mathrm{cmbs}$ ) yielded a date similar to that derived from four Rabdotus shells from 130 to $140 \mathrm{cmbs}$. Although a slight difference existed in elevation for these two obtained dates of ca. 3220 and 3270 B.P. respectively, and they were from different units, these results indicate that Rabdotus shell dates may be more accurate than the humate dates in this setting.

It appears that the top $160 \mathrm{~cm}$ of deposits represent a time span that covers roughly the last 5,000 years. The upper peak (ca. 60 to $90 \mathrm{cmbs}$ ) in frequencies of cultural materials identified that appears associated with the Pedernales point was not directly dated. However, extrapolation from Zone 8

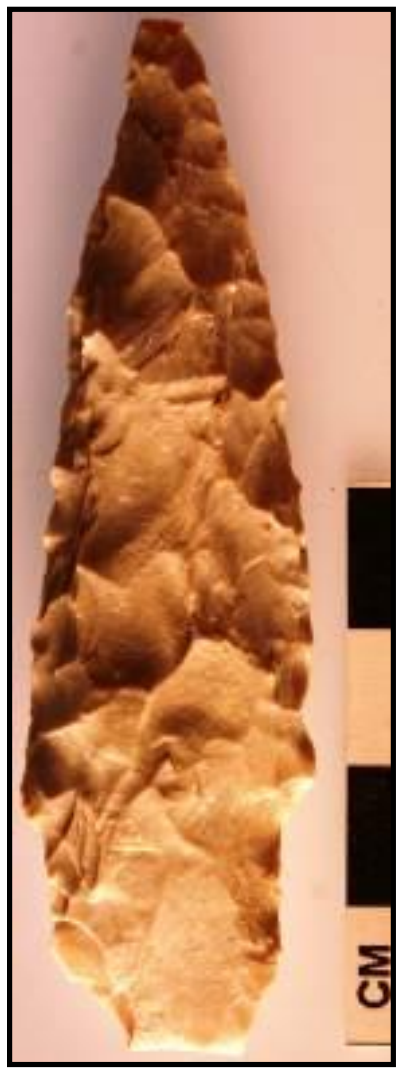

Figure 6-14. Complete Morrill projectile point (\#154-10) from $115 \mathrm{cmbs}$ in TxDOT BT 7.

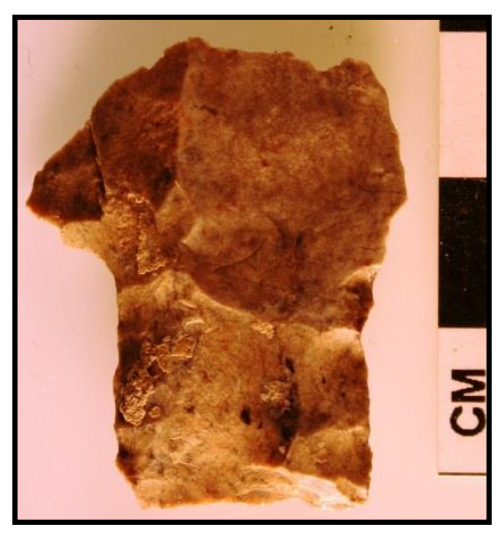

Figure 6-15. Basal section of a possible Morrill projectile point (\#93-10) from 120 to 130 cmbs in TU 9. 
Table 6-1. Pertinent Data Concerning the Radiocarbon Samples and Results.

\begin{tabular}{|c|c|c|c|c|c|c|c|c|c|c|c|}
\hline PNUM & Unit & Level & $\begin{array}{l}\text { Depth } \\
\text { (cmbs) }\end{array}$ & Context & Material & Type & Wt (g) & $\begin{array}{l}\text { Measured } \\
\text { Age (B.P.) }\end{array}$ & $\begin{array}{c}13 \mathrm{C} / 12 \mathrm{C} \\
\text { Ratio } \\
(\% \text { o })\end{array}$ & $\begin{array}{c}\text { Conventional } \\
\text { Age (B.P.) }\end{array}$ & $\begin{array}{c}\text { Two Sigma } \\
\text { Calibrated Ages }\end{array}$ \\
\hline 89 & 9 & 12 & $110-120$ & $\begin{array}{r}\text { Same elevation } \\
\text { as Morrill Point }\end{array}$ & Snail Shell & 20 Rabdotus & 61.2 & $3800 \pm 30$ & -10.3 & $4040 \pm 30$ & Cal BC 2830 to 2480 \\
\hline 113 & BT 7 & & 113-118 & Top of dark zone & Sediment & Humate & 208.8 & $3230 \pm 30$ & -19.7 & $3310 \pm 30$ & Cal BC 1680 to 1520 \\
\hline 58 & 1 & 14 & $130-140$ & $\begin{array}{c}\text { Same zone as } \\
\text { sediment }\end{array}$ & Snail Shell & 9 Rabdotus & 5.3 & $2320 \pm 30$ & -9.6 & $2570 \pm 30$ & Cal BC 800 to 670 \\
\hline 109 & 1 & & $133-138$ & $\begin{array}{c}\text { Bottom edge of } \\
\text { dark zone }\end{array}$ & Sediment & Humate & 203.5 & $3120 \pm 40$ & -17.9 & $3240 \pm 40$ & Cal BC 1610 to 1420 \\
\hline 60 & 2 & 14 & $130-140$ & $\begin{array}{c}\text { Same zone as } \\
\text { sediment }\end{array}$ & Snail Shell & 21 Rabdotus & 26.0 & $2420 \pm 30$ & -9.8 & $2670 \pm 30$ & Cal BC 890 to 800 \\
\hline 108 & 2 & & 132-141 & $\begin{array}{c}\text { Just below dark } \\
\text { zone } \\
\end{array}$ & Sediment & Humate & 204 & $3090 \pm 30$ & -18.6 & $3190 \pm 30$ & Cal BC 1510501410 \\
\hline 53 & 3 & 14 & 130-140 & $\begin{array}{c}\text { Same zone as } \\
\text { sediment }\end{array}$ & Snail Shell & 4 Rabdotus & 5.2 & $3270 \pm 30$ & -10.1 & $3510 \pm 30$ & Cal BC 1920 to 1750 \\
\hline 107 & 3 & & 130-140 & $\begin{array}{c}\text { Bottom edge of } \\
\text { dark zone }\end{array}$ & Sediment & Humate & 209.7 & $3520 \pm 40$ & -18.3 & $3630 \pm 40$ & Cal BC2130 to 1890 \\
\hline 99 & 9 & 14 & $130-140$ & $\begin{array}{l}\text { Below dense } \\
\text { zone }\end{array}$ & Snail Shell & 3 Rabdotus & 4.8 & $3810 \pm 30$ & -8.7 & $4080 \pm 30$ & Cal BC 2850 to 2500 \\
\hline 106 & BT 7 & - & $130-140$ & $\begin{array}{c}\text { Near middle of } \\
\text { dark zone }\end{array}$ & Sediment & Humate & 202.6 & $3800 \pm 30$ & -21.3 & $3860 \pm 30$ & Cal BC 2460 to 2200 \\
\hline 128 & BT 7 & - & 130 & \begin{tabular}{|c|}
$\begin{array}{c}\text { In dark sediment } \\
\text { zone }\end{array}$ \\
\end{tabular} & Bone & 1 frag & 0.1 & NA & & & \\
\hline 127 & 7 & 15 & $140-150$ & $\begin{array}{c}\text { Lowest } \\
\text { occupation zone }\end{array}$ & Bone & tooth frag & 0.8 & $3220 \pm 30$ & -19.4 & $3310 \pm 30$ & Cal BC 1680 to 1510 \\
\hline 114 & BT 7 & - & 182-187 & $\begin{array}{c}\text { Below lowest } \\
\text { cultural material }\end{array}$ & Sediment & Humate & 203 & $5020 \pm 40$ & -19.9 & $5100 \pm 40$ & Cal BC 3790 to 3790 \\
\hline
\end{tabular}

(Analytic Unit 6) at 41MM340 just east of the Barrett site yielded charcoal dates in the range of 3000 B.P. associated with 18 Pedernales points provides an approximate time for this upper peak (Mahoney and Tomka 2000; Mahoney et al. 2003). Cultural materials found in the two lower peaks between 110 to $160 \mathrm{cmbs}$ represent a time range of around 1,500 years, roughly between about 2700 and 3850 B.P., and likely older than ca. 3000 B.P. Culturally this relates to the general Late Archaic I period as defined by Johnson and Goode (1994) and Collins (2004). Previously, this would have been assigned to the Middle Archaic period according to Prewitt (1981 and 1985). This time period is not well represented in the archeological literature of the Blackland Prairie (see Chapter 3.0 Archeological Background).

\subsection{COMMENTS ON FREQUENCIES OF MATERIAL CLASSES}

The $11.4 \mathrm{~m}^{3}$ of hand-excavated deposits yielded 3,123 pieces of cultural debris plus 20 sediment samples (Table 6-2). The three classes with the highest frequencies, representing 95 percent of the recovered materials, are lithic debitage, burned rocks, and mussel shell, all discussed below.

\subsubsection{Lithic Debitage}

The 1,521 pieces of lithic debitage (roughly 49 percent of the total assemblage collected) were concentrated in the lower half of the deposits, below $60 \mathrm{cmbs}$. The single greatest frequency was between 110 and $120 \mathrm{cmbs}$ in TU 9 with some 356 pieces from a $10 \mathrm{~cm}$ level followed by 131 pieces 
Table 6-2. Artifact Classes and Total Counts by Class for $41 \mathrm{M} 382$.

\begin{tabular}{|l|c|}
\hline Artifa ct & Tota I \\
\hline Bone & 38 \\
\hline Burned Rock & 1200 \\
\hline Charcoal & 3 \\
\hline Cobble & 1 \\
\hline Lithic debitage & 1521 \\
\hline Lithic Tool & 15 \\
\hline Modern & 1 \\
\hline Mussel Shell & 251 \\
\hline Pebble & 86 \\
\hline Quartz & 1 \\
\hline Sediment Sample & 20 \\
\hline Unidentified Rock & 6 \\
\hline Grand Tota I & $\mathbf{3 1 4 3}$ \\
\hline
\end{tabular}

in the immediately underlying level. These high frequencies were within the second recognized peak. The relatively high density of debitage is anomalous in this zone and site, and probably represents a knapping or dump area.

Test Unit 6 yielded a moderately high lithic debitage frequency, with roughly 155 pieces distributed over three levels in the lowest identified peaks between 130 and $160 \mathrm{cmbs}$. Test Unit 2, again adjacent to BT 2, also yielded a moderate frequency of lithic debitage with 90 pieces between 140 and $160 \mathrm{cmbs}$. These moderate frequencies are likely associated with the lowest peak in debris density.

The relatively high frequency of lithic debris recovered in two of the vertical peaks indicates that knapping activities were carried out during those intervals of site occupation. This is despite an absence of source outcrops in the immediate vicinity of this site and the overall small size of most chert cobbles among the burned rocks.

\subsubsection{Burned Rocks}

Burned rocks $(N=1,200)$ are the second most frequent class recovered (see Table 6-2). The highest frequency $(N=112)$ was between 110 and
$112 \mathrm{cmbs}$ in TU 9. This is the same level as the highest frequency of lithic debitage in the middle peak. The second highest frequency $(N=105)$ was between 140 and 150 in TU 2 and was associated with moderate frequencies of lithic debitage in that same level and unit. A cluster of cultural materials with burned rocks and lithic debitage in this same unit was identified as Feature 2 (see discussion below). The presence of burned rocks in each of the three major identified vertical zones indicates that hot rock cooking was one of the activities during all periods of site occupation.

\subsubsection{Mussel Shells}

Mussel shells account for the third most frequent class of material recovered, with some 251 hinges and/or hinge teeth that represent nearly eight percent of the recovered artifacts (see Table 6-2). Many more fragments were present but only the count of hinge and/or teeth portions provide an accurate count of the number of valves represented. The highest frequencies were in the two arbitrary levels between 130 and $140 \mathrm{cmbs}$ in TU 3, which bracketed the lowest recognized peak in debris density. This high concentration was identified as Feature 3 (see below for description). These shells were part of the lowest peak and reveal a horizontal patterning of different classes of debris distributed in different areas across this one zone. Two moderate frequencies of valves were also present in two different TUs. Test Unit 1 between 140 and 150 cmbs yielded a moderate frequency of 15 hinges, again in the lowest peak. Test Unit 9 yielded a moderate frequency of 17 hinges between 80 and $90 \mathrm{cmbs}$ within the upper peak. Apparently mussels were exploited during all three periods of occupation at this location.

This overview of the horizontal and vertical distribution of the three major classes of debris indicates that different classes of materials from the three identified components peaks in vertical distribution likely reflect horizontal patterning of activities within the various camping episodes. The 
various activity areas in the camping episodes did not, as should be expected, occur at the same locations over the combined time span of the several occupations represented within the area investigated.

\subsection{VERTICAL POSITIONS OF THE PROJECTILE POINTS}

Only three diagnostic projectile points were recovered and all three came from the same area, in TxDOT Trench 7 or TU 9, on the western side of that trench. All three are dart points that pertain to the long-lived Archaic continuum and were from the lower $110 \mathrm{cmbs}$. The proximal half of a Pedernales point (\#70-10) (see Figure 6-12; see Turner et al. 2011:149 for comparisons) was recovered in situ at $70 \mathrm{cmbs}$ from $\mathrm{TU} 9$, without any discernible indication of a disturbed context. A complete, patinated Morrill point (\#154-10) (see Figure 6-14) was recovered by TxDOT archeologist in situ in TxDOT Trench 7 wall at 115 cmbs. The third is a possible Morrill point (\#93-10) (see Figure 6-15; see Turner et al. 2011:139 for comparisons) from between 120 and $130 \mathrm{cmbs}$ in TU 9. If these projectiles points have been properly identified, then they appear to be in correct chronological order according to the depths at which they were found.

\subsection{CULTURAL FEATURES}

Four clusters of cultural material were assigned feature numbers in the field. Each cluster is described and interpreted below, and illustrated with associated drawings and photographs.

\subsubsection{Feature 1}

This was a mussel shell concentration with a few scattered burned rocks and pieces of lithic debitage distributed across parts of TU 3 between 134 and 142 cmbs (Figures 6-16 and 6-17). It included at least 21 mussel shell pieces, 5 lithic debitage, and 8 burned rocks. These cultural items, all within a dark yellowish-brown (10YR 4/4) sediment, extended across the entire 100 -by- $50 \mathrm{~cm}$ unit in no apparent pattern, in a single layer, on a relatively level plane. The feature was photographed and drawn in plan view. Sediment, approximately 18 liters, from around and just below the artifacts was collected together with the cultural materials. Following the removal of the artifacts the adjacent unit walls were examined as a profile. The unit walls revealed no basin of detectable soil color change below the materials. This feature is part of the lowest vertical peak in frequency across the area.

A $54 \mathrm{~g}$ fragment of a burned chert rock (\#68-1) was analyzed for starch grains. The results were negative (Appendix B). About 11 liters of sediment from the 18.5 liters collected was floated in the laboratory and the heavy and light fractions picked. The initial scan of the heavy and light fractions revealed multiple tiny, less than $2 \mathrm{~mm}$ pieces of wood charcoal, hundreds of tiny mussels shell fragments, tiny pieces of lithic debitage, a few complete and fragmented snail shells (e.g., Helicinidae, Polygryra, etc.), tiny burned and unburned bone fragments, a few fragments of what appear to be nut shells, and a few tiny burned chert fragments. Some tiny mussel shell fragments were a dark gray, which indicates these may have been heated and may represent cultural manipulation.

The diverse and scattered nature of Feature 1 is interpreted to reflect discard of cultural materials within an occupation zone.

\subsubsection{Feature 2}

This feature consisted of a tight concentration of 6 pieces of lithic debitage, 3 burned rocks, 3 pebbles, and a single mussel shell at $140 \mathrm{cmbs}$ in TU 2 (Figures 6-18 and 6-19). These artifacts were toward the southwestern side of the unit in an apparent occupation zone, the lowest peak identified. Another mussel shell was at this same depth about $15 \mathrm{~cm}$ outside the concentration to the east. The concentration measured about $20 \mathrm{~cm}$ eastwest by $20 \mathrm{~cm}$ north-south. No discoloration, charcoal flecking, or other soil discoloration was 


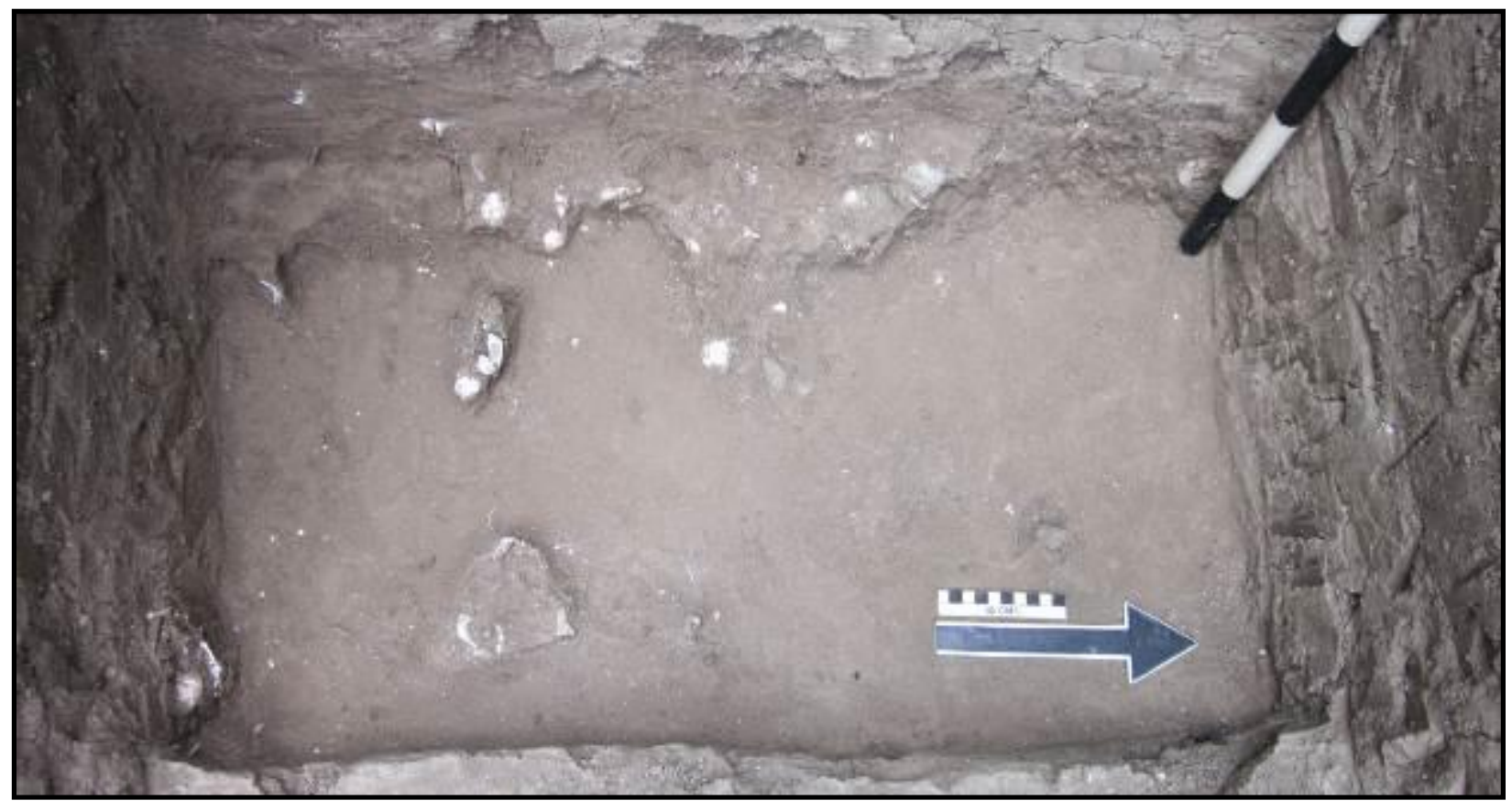

Figure 6-16. Plan view photograph of Feature 1, concentration of cultural materials in Test Unit 3 at $140 \mathrm{cmbs}$ off Backhoe Trench 3.

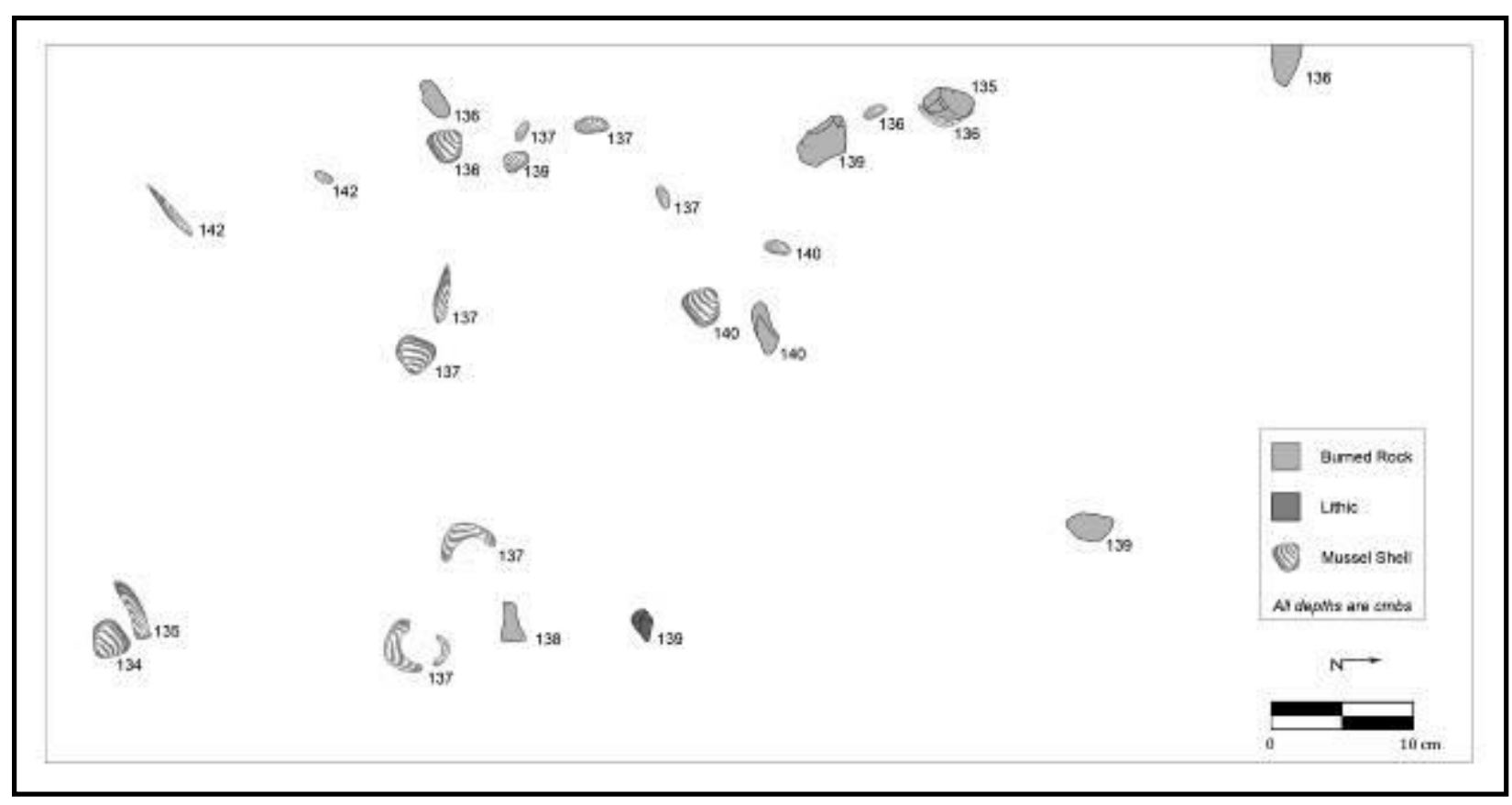

Figure 6-17. Plan view drawing of Feature 1, concentration of cultural materials in Test Unit 3 at $140 \mathrm{cmbs}$ off Backhoe Trench 3. 


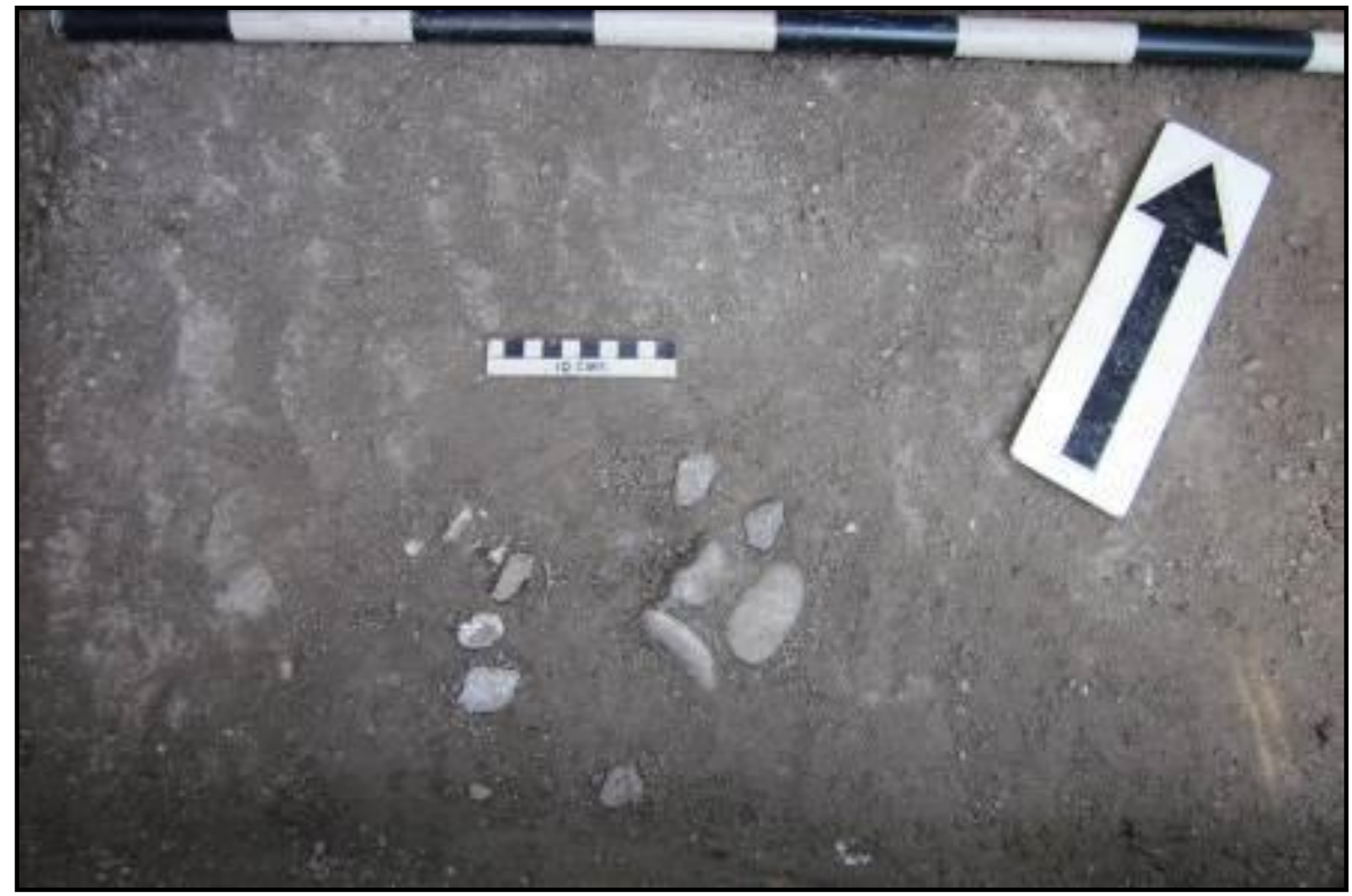

Figure 6-18. Plan view photograph of Feature 2, cluster of cultural materials in Test Unit 2, at $140 \mathrm{cmbs}$, off Backhoe Trench 2.

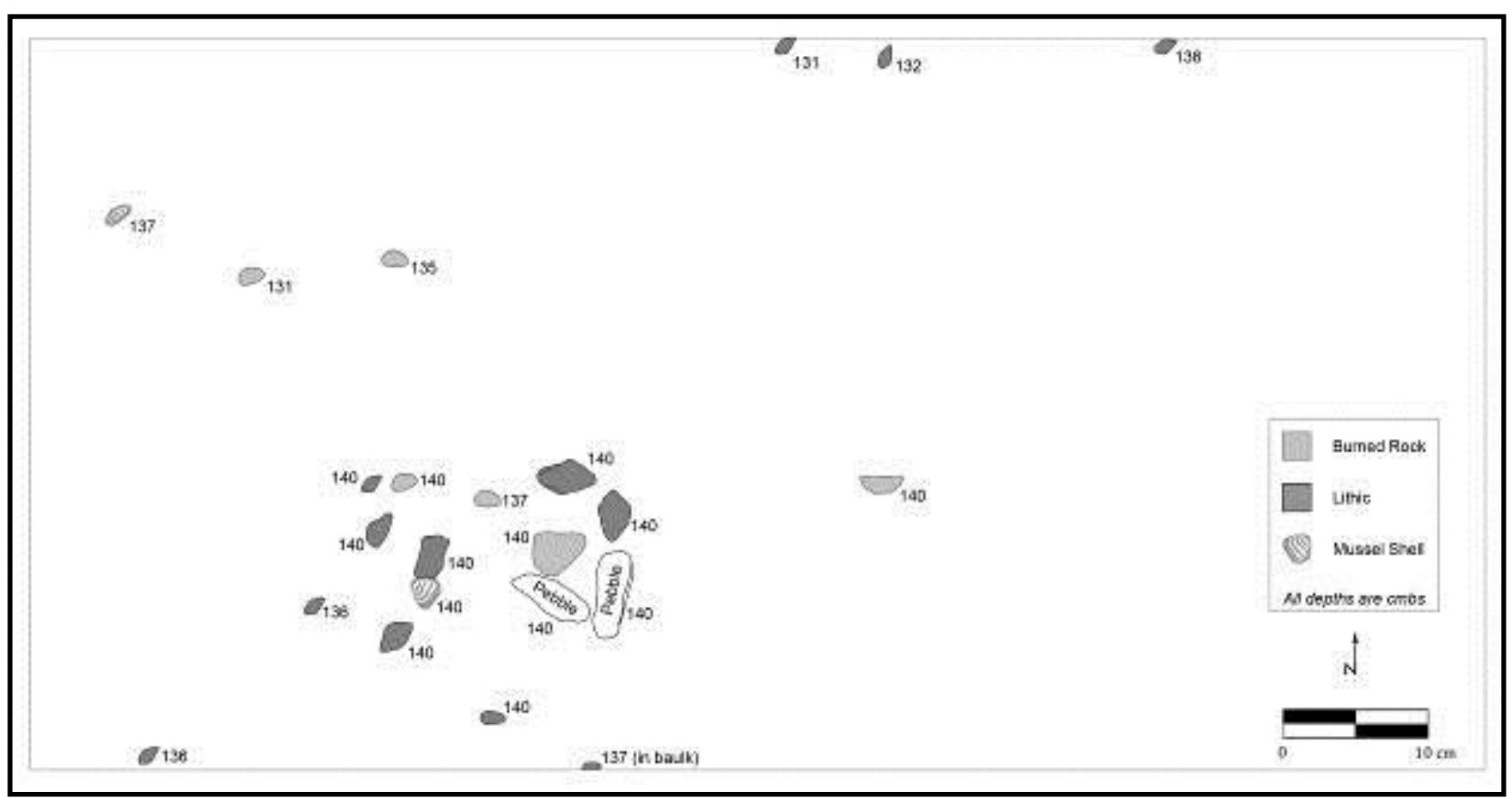

Figure 6-19. Plan view drawing of Feature 2, cluster of cultural materials in Test Unit 2, at 140 cmbs, off Backhoe Trench 2. 


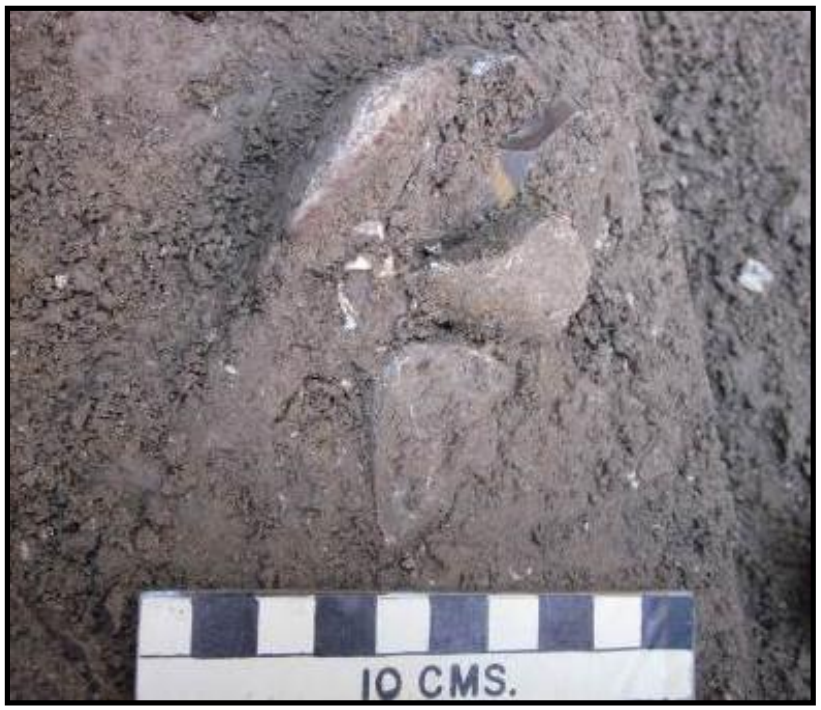

Figure 6-20. Close-up of Feature 3, a tight cluster of burned rocks in Test Unit 6, at 112 cmbs, off Backhoe Trench 2.

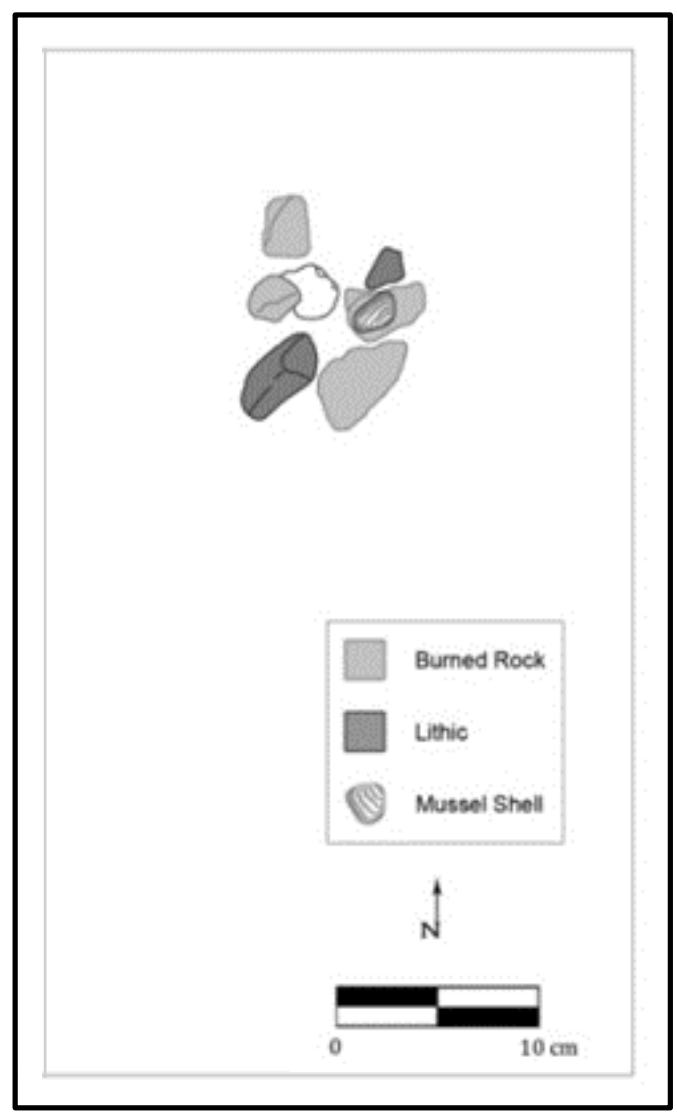

Figure 6-21. Plan view drawing of Feature 3, cluster of cultural materials in Test Unit 6, at 112 cmbs, off Backhoe Trench 2. observed in this dark yellowish-brown (10YR 4/4) colored clay matrix. A sediment sample from around and below the rocks and flakes was collected. About three liters of sediment was floated in the laboratory and the heavy and light fractions picked. The initial scan of the heavy and light fractions revealed a few tiny pieces of wood charcoal, hundreds of tiny mussels shell fragments, pieces of lithic debitage, a few complete and fragmented snail shells (e.g., Helicinidae, Polygryra, etc.). Some tiny mussel shell fragments were a dark gray, which indicates these may have been heated. Scattered roots were in the vicinity but no obvious disturbances were observed. The surrounding sediment in this $10 \mathrm{~cm}$ level yielded 8 to 10 pieces of mussel shell, 105 burned rock fragments and 40 pieces of lithic debitage. The concentration was photographed and drawn in plan view. This concentration is interpreted to represent disposal of debris cleaned from activity areas within the occupied campsite.

\subsubsection{Feature 3}

A tight cluster of four burned rocks, two lithic debitage, and a mussel shell were discovered in the southwestern corner of TU 6 between 110 and 112 cmbs. This cluster measured $10 \mathrm{~cm}$ east-west by 12 $\mathrm{cm}$ north-south (Figures 6-20 and 6-21). No soil discoloration, charcoal flecks, or other staining was observed under this cluster. Following photographing, these materials were collected along with a small soil sample for phytolith analysis from immediately below the rocks. Feature 3 was part of the materials that represent the middle peak identified across the site. The cluster is interpreted to be a small dump of items from a heating/cooking feature. This cluster was apparently at the top of the second identified occupation zone and at approximately the same depth as the Morrill point at $115 \mathrm{cmbs}$ in TxDOT Trench 7 further south. 


\subsubsection{Feature 4}

This feature was observed in the eastern wall of the reopened TxDOT Trench 7 after the wall had been picked for documentation by the geoarcheologist (Figure 6-22). This would indicate part of the feature was removed by digging the trench. Feature 4 appeared as an arcuate alignment of at least 8 small burned rocks and pebbles in a $60 \mathrm{~cm}$ long section of the trench wall. The positions of the eight visible rocks in the profile indicate a slight basin shape, but no soil discoloration or charcoal flecking was visible under the rocks in this profile. The elevation of the rocks and pebbles was generally between 101 and $110 \mathrm{cmbs}$.

The rocks rested on or just in the ABk soil horizon and are considered part of the middle cultural peak identified. Feature 4 was on the opposite side of TxDOT Trench 7 from which the Morrill point (\#154-10) was found and part of a high concentration of cultural debris in this vertical zone. The general small size of the pebbles and the use of chert for heating indicates limited access to larger rocks on the part of the site's occupants. A couple of fragments of mussel shell and a chert flake were just above the rocks. After the photograph was taken seven burned rocks were collected.

One nearly complete chert burned rock weighing $109 \mathrm{~g}$ was selected and analyzed for starch. The analysis yielded no starch grains (Appendix B).

The arcuate, basin-shaped profile of this feature indicates that it served as an in situ heating feature in contrast with the previous features (Table 6-3). The lack of charcoal under the rocks likely results from poor preservation. As mentioned above, this heating feature was found at about the same elevation as the Morrill point discovered by TxDOT archeologists on the opposite wall of TxDOT Trench 7.

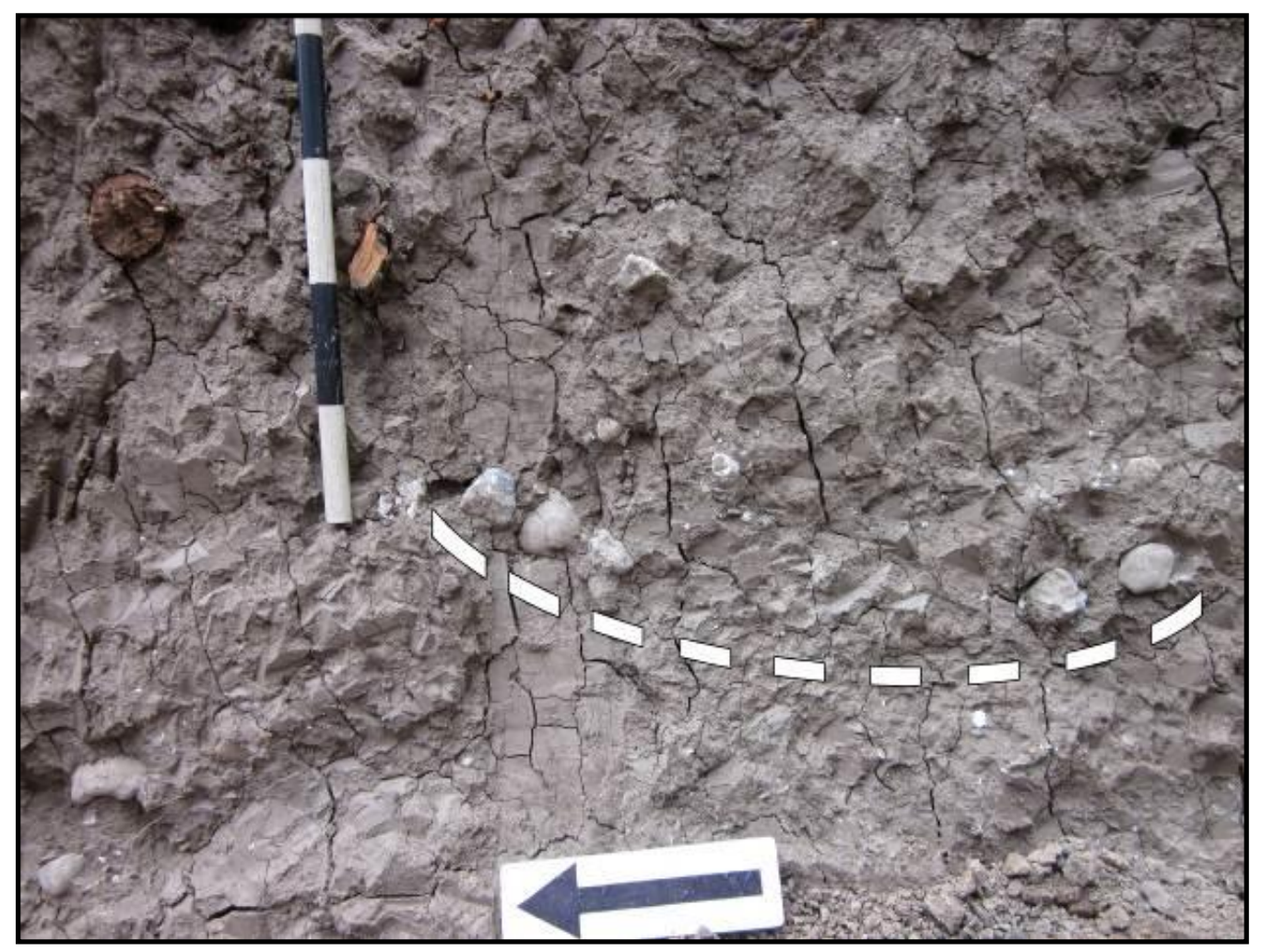

Figure 6-22. Profile of eastern wall of Backhoe Trench 7, revealing Feature 4, a small burned rock concentration at $110 \mathrm{cmbs}$. 
Table 6-3. Summary of Feature Data.

\begin{tabular}{|c|c|c|c|c|}
\hline & Feature 1 & Feature 2 & Feature 3 & Feature 4 \\
\hline Unit & Test Unit 3 & Test Unit 2 & Test Unit 6 & Trench 7 Wall \\
\hline $\begin{array}{l}\text { Depth Below Surface } \\
(\mathrm{cm})\end{array}$ & $134-142$ & 140 & $110-112$ & $101-110$ \\
\hline Occupation Zone & Lowest & Lowest & Middle & Middle \\
\hline $\begin{array}{l}\text { Radiocarbon Age (B.P.) } \\
\text { of Cultural Zone }\end{array}$ & $\begin{array}{c}4 \text { Rabdotus }= \\
3510 \pm 30\end{array}$ & $\begin{array}{c}21 \text { Rabdotus }= \\
2670 \pm 30\end{array}$ & & \\
\hline Feature Class & $\begin{array}{l}\text { Mussel Shell } \\
\text { Concentration }\end{array}$ & $\begin{array}{l}\text { Cultural Debris } \\
\text { Concentration }\end{array}$ & $\begin{array}{c}\text { Debris } \\
\text { Concentration }\end{array}$ & Hearth ? \\
\hline Shape & Unknown & Irregular & Circular & Unknown \\
\hline Profile & Flat & Flat & Flat & Basin \\
\hline Length $(\mathrm{cm})$ & 100 & 65 & 12 & 60 \\
\hline Width $(\mathrm{cm})$ & 50 & 45 & 10 & Unknown \\
\hline Thickness (cm) & 8 & 4 & 2 & 8 \\
\hline Mussel Shells & 21 & 1 & 1 & None \\
\hline Charcoal & None & None & None & None \\
\hline Lithic debitage & 5 & 6 & 2 & None \\
\hline Burned Rock Count & 8 & 3 & 6 & 8 \\
\hline Burned Rock Weight (g) & ca. 1200 & ca. 450 & ca. 775 & ca. 1050 \\
\hline Burned Rock Type & Chert & Chert & Chert & Chert \\
\hline
\end{tabular}

\subsection{MATERIAL CLASSES}

The following section presents the different classes of cultural materials recovered from the excavations. This includes the materials recovered by TxDOT archeologists during the initial site discovery. The discussions include total counts by class as well as limited observations on selected pieces.

\subsubsection{Chipped Stone Tools}

The lithic artifacts from the Barrett site were recovered from nine Test Units (TUs). Table 6-4 provides the breakdown of tool classes. Radiocarbon dates for this component range from 5000 to 3000 B.P. (conventional age) based on twelve acceptable dates derived from various components and depths (see Chapter 5.0 for discussion of stratigraphy). The following presentation discusses tool data stemming from analysis that provides a characterization of the lithic assemblage to contribute to the assessment of the NRHP eligibility of the site.
Hand-excavations yielded a sample of 30 chipped stone tools. This group represents 1.8 percent of all recovered chipped stone materials, the remainder being mostly debitage. Chipped stone tool descriptions are presented below by tool class. A number of tools in each class were also selected for detailed description as representative examples of that class.

\subsubsection{Projectile Points}

Projectile points comprise 10 percent $(N=3)$ of the chipped stone tool sample (see Figures 6-12, 6-14 and 6-15). This group includes one complete specimen (\#154-10), and two proximal-medial fragments (\#70-10 and \#93-10).

These items are classified as stemmed points based on their metric and morphological characteristics, and their similarity to chipped stone bifaces generally assumed to be dart points (Suhm and Jelks 1962; Turner et al. 2011). Nonetheless, we recognize that these specimens, as well as many other artifacts commonly identified as dart points, 
Table 6-4. Artifact Class Frequency for Component A.

\begin{tabular}{|c|c|}
\hline Artifact Classes & Count $(\boldsymbol{N})$ \\
\hline Projectile Points & 3 \\
\hline Bifaces & 4 \\
\hline Scraper & 1 \\
\hline Edge-Modified Flakes & 22 \\
\hline Total & $\mathbf{3 0}$ \\
\hline
\end{tabular}

could have had multiple uses (e.g., as both dart points and knives).

Two morphological styles are present within this tool class assemblage: those projectiles resembling the Pedernales type and those that resemble the Morrill type. Pedernales points range widely in size and shape, though they typically have a rectangular, concave to bifurcated stem (Suhm and Jelks 1962). The base is often thinned and characterized by a prominent flake scar on one or both sides (Turner et al. 2011:148). The age range for these has been determined to be between 4000 and 3200 years ago (Collins 1995). Morrill points are long and slender with a triangular body. They have rectangular stems and slightly convex basal edges (Johnson 1962; Suhm and Jelks 1962; Turner et al. 2011:139). Metric measurements and qualitative observations for the projectile points are presented in Table 6-5.

Specimen \#154-10. This projectile was recovered by TxDOT archeologists from $115 \mathrm{cmbs}$ in TxDOT Trench 7 and was initially referred to as a Darl point. Elton Prewitt was kind enough to provide his observations concerning this specimen. Based on his first hand observations he concluded that this specimen does not fit well with any of the known types (Prewitt personnel communication, August 13, 2012), but is similar to many stems types more frequent in the northern part of the state. Prewitt's identification was based on the following observations: heavy surface patination, rough workmanship partially due to internal flaws, one or more resharpening episodes, a long, narrow blade with gently convex lateral edges, alternately beveled right faces with snap fracture on tip, abrupt shoulders, gently expanding stem with straight lateral edges and alternately beveled right face, edge grinding of the lateral stem edges, and a gently concave base that also has edge grinding. Under a short-wave ultraviolet (UV) light this piece florescence's a bright yellow, typical of Edwards chert.

Its morphology resembles the Morrill point type. The outer surface of the point is patinated giving it an ashy, gray appearance. One of the stem corners was inadvertently chipped during the excavation of TxDOT Trench 7, which reveals a darker gray interior color of the material. This specimen appears to be a finished tool and it exhibits no attribute to account for its discard. The base is relatively straight with parallel lateral stem edges, and the shoulders are weak. The lateral blade edges are slightly asymmetrical, signifying some degree of resharpening. A sediment sample at this depth was submitted for radiocarbon AMS dating and yielded a conventional date of $3310 \pm 30$ B.P. (2sigma cal B.C. 1680 to 1520 ). This places it in the Late Archaic period following Collins (2004).

Specimen \#70-10 was from $70 \mathrm{cmbs}$ in TU 9 and stylistically similar to a Pedernales form (Bell 1960; Prewitt personnel communication, August 13, 2012; Suhm and Jelks 1962; Turner et al. 2011:148-149). The flaking pattern on both faces is complete and random. The stem is slightly contracting with a concave (almost bifurcated) base but it appears crushed, with multiple short step fractures on one face, which has created the appearance of a shallow concave base (Stem Form 5 in Tomka et al. 2003 classification). The stem has one beveled edge, the edges are straight, is relatively thick with ground/worn edges. The body is well-made with broad flake scars across the majority of both faces and small flake scars along the margins. This point is fairly symmetrical in shape and moderately reworked on the lateral edges above the shoulders. 
Table 6-5. Projectile Point Attributes.

\begin{tabular}{|c|c|c|c|}
\hline & \multicolumn{3}{|c|}{ Specimen No. } \\
\hline & 154-10 & $70-10$ & 93-10 \\
\hline Technology & Chipped Stone & Chipped Stone & Chipped Stone \\
\hline Group & Tools & Tools & Tools \\
\hline Subgroup & Complex Detachment & Complex Detachment & Complex Detachment \\
\hline Class & Biface & Biface & Biface \\
\hline Subclass & Formal & Formal & Formal \\
\hline Type & Projectile Point & Projectile Point & Projectile Point \\
\hline Identity & Morrill & Pedernales & Morrill \\
\hline Maximum Length & 71.5 & 47 & 30.8 \\
\hline Maximum Width & 20.7 & 29.2 & 25.2 \\
\hline Maximum Thickness & 8.8 & 7.8 & 6.7 \\
\hline Weight & 12.6 & 11.2 & 4.6 \\
\hline Edge Angle 1 & 75 & 70 & 75 \\
\hline Edge Angle 2 & 70 & 70 & 80 \\
\hline Stage & Finished product & Finished Product & Indeterminate \\
\hline Portion & Complete & Prox-Medial & Prox-Medial \\
\hline Failure/Discard & Indeterminate & Snap/End Shock & Indeterminate \\
\hline Alteration & White Patina & None Observed & Thermal \\
\hline Edge Morph Distal & Point & N/A & N/A \\
\hline Edge Morph Proximal & Straight & Concave & Straight \\
\hline Edge Morph Left Lateral & Straight & Straight & Straight \\
\hline $\begin{array}{lll}\text { Edge } & \text { Morph } & \text { Right } \\
\text { Lateral } & & \\
\end{array}$ & Straight & Straight & Straight \\
\hline Flake Scar Pattern & Random & Random & Random \\
\hline Edge Construction 1 & Indeterminate & Snap break & Indeterminate \\
\hline Edge Construction 2 & Indeterminate & Snap break & Indeterminate \\
\hline Lithology & Chert & Chert & Chert \\
\hline Point Class & Stemmed & Stemmed & Stemmed \\
\hline Point Length & 55.8 & 29.4 & 14.2 \\
\hline Point Width & 20.2 & 28.6 & 25.1 \\
\hline Blade Length, Left & 55.43 & 25.34 & 14.36 \\
\hline Blade Length, Right & 57.13 & 29.18 & 17 \\
\hline Base/Stem, Length & 15.9 & 20.74 & 17.39 \\
\hline Base/Stem Width & 16.65 & 16.64 & 17.11 \\
\hline Neck Thickness & 7.35 & 7.74 & 6.76 \\
\hline Neck Width & 15.78 & 16.3 & 16.98 \\
\hline Notch Depth, Left & N/A & 1.03 & N/A \\
\hline Notch Depth, Right & N/A & 1.32 & N/A \\
\hline Stem Form & Parallel & Contracting & Parallel \\
\hline Distal Base Form & Straight & Concave & Straight \\
\hline Blade Curvature, Left & Straight & Indeterminate & Indeterminate \\
\hline Blade Curvature, Right & Straight & Indeterminate & Indeterminate \\
\hline Shoulder Angle, Left & 74 & 75 & N/A \\
\hline Shoulder Angle, Right & 70 & 75 & N/A \\
\hline Shoulder Junction & Indet & Angular & Indet \\
\hline Base Angle, Left & 74 & 77 & 88 \\
\hline Base Angle, Right & 81 & 75 & 88 \\
\hline Symmetry & Asymmetrical & Asymmetrical & Indet \\
\hline
\end{tabular}


There is a break at the distal end that appears to represent an end snap break, possibly resulting from use. This point was manufactured from a dark gray chert that has tiny spots of lighter color. Under a short-wave UV light it fluoresces a dark orangish to reddish color. This color is possibly of nonEdwards material.

Specimen \#93-10. This point was between 120 and $130 \mathrm{cmbs}$ in TU 9. This pot-lidded basal fragment is from a straight-stemmed dart point. This proximal-medial fragment has morphological attributes similar to the base of a Morrill type (Turner et al. 2011:139). The stem is rectangular with parallel, unground lateral edges and a straight base that exhibits one major thinning scar up the stem on one face and an unground basal edge. Given its fragmented condition, it is difficult to determine the degree of tool finishing or reworking as those diagnostic portions are absent. Thermal alteration appears to have been the cause of the fragmentation. This piece was manufactured from a light gray chert with darker gray irregular shaped spots and squiggly lines. Under a short-wave ultraviolet light it fluoresces a duller yellowish color rather than the more common bright yellow fluorescence typical of Edwards chert materials.

Other than the Pedernales specimen, the points recovered cannot be typologically identified with high confidence, although they are similar in general form to Morrill point type. Radiocarbon dating the deposits indicate the specimens are from Late Archaic I period according to Johnson and
Goode (1994) and Collins (2004), but are part of Prewitt's $(1981,1985)$ Middle Archaic period.

\subsubsection{Bifaces}

Four bifaces (\#61-10, \#76-10, \#105-10, and \#13612) comprise 13.3 percent of the chipped stone tools (Table 6-6; Figure 6-23).

Width-to-Thickness Ratios, Reduction Stage and Tool Use-life

As explained in the methodology section of this report, width-to-thickness ratios were recorded to provide a morphological index for the tools in this class. Specifically, Callahan (1979) devised this classification scheme to acknowledge trends observed amongst bifaces in Paleoindian assemblages and suggested that they represented indices in a reduction scheme where low width-tothickness ratios denoted earlier reduction stages and high ratios denoted later reduction stages or perhaps finished forms. TRC has acknowledged in recent publications (e.g., Quigg et al. 2010, 2011a) that microscopic wear data on such bifaces show evidence of use and hafting across a wide range of early through late "stage" bifaces. These data could very well indicate that diversity in width-tothickness ratios represent different stages in use-life that may not be directly proportional to level of reduction. Do these discrepancies constitute a reinterpretation of biface use-life and its association to morphological form? We believe so. However, we stop short of changing our classification terminology (i.e., Stages 1-5).

Table 6-6. Selected Attributes on Bifaces from 41MM382.

\begin{tabular}{|c|c|c|c|c|c|c|c|c|c|c|c|}
\hline PNUM & $\begin{array}{c}\text { Test } \\
\text { Unit }\end{array}$ & $\begin{array}{c}\text { Lev } \\
\text { el }\end{array}$ & $\begin{array}{c}\text { Depth } \\
(\mathbf{c m b s})\end{array}$ & $\begin{array}{c}\text { Tool } \\
\text { Type }\end{array}$ & $\begin{array}{c}\text { Length } \\
(\mathbf{m m})\end{array}$ & $\begin{array}{c}\text { Width } \\
\mathbf{( m m})\end{array}$ & $\begin{array}{c}\text { Thick } \\
\mathbf{n e s} \\
\mathbf{( m m})\end{array}$ & $\begin{array}{c}\text { Wt } \\
(\mathbf{g})\end{array}$ & $\begin{array}{c}\text { Material } \\
\text { Type }\end{array}$ & $\begin{array}{c}\text { Thermal } \\
\text { Alteration }\end{array}$ & Completeness \\
\hline $61-10$ & 1 & - & $\begin{array}{c}150- \\
152\end{array}$ & Biface & 12.67 & 24.6 & 6.13 & 2 & chert & Yes & Distal fragment \\
\hline $76-10$ & 9 & 9 & $80-90$ & Biface & 17.96 & 26.17 & 8.41 & 5.2 & chert & Yes & Medial fragment \\
\hline $105-10$ & 8 & 15 & $\begin{array}{c}140- \\
150\end{array}$ & Biface & 52.49 & 29.8 & 12.33 & 22.2 & chert & Yes & Medial fragment \\
\hline $136-10$ & BT 2 & - & $28-30$ & Biface & 17.54 & 29.07 & 9.19 & 3.7 & chert & No & Lateral edge \\
\hline
\end{tabular}




\section{Metric Attributes of Biface Assemblage}

Two specimens are complete, two are distal fragments, two are distal-medial fragments, and two are medial fragments. Specimens in this group were fashioned from Edwards chert. Descriptions of the bifaces are presented below with metric attributes presented for each in Table 6-6.

Biface \#61-10. This specimen is a distal biface fragment that was fashioned from a beige/tan material, presumably Edwards chert. It is the thinnest biface of the group and a prominent potlid is evidence of thermal alteration. The apparent transverse break appears to be the result of an end snap that may have occurred during use.

Biface \#76-10. This biface is a medial fragment with transverse fractures on both ends (Figure 623). Both faces exhibit potlidding, a definite sign of thermal alteration. The surface of the tool material is an ashy gray color which may have been an effect of heating. A recent chip on one of the lateral edges suggests the interior is much darker gray, which may support the presence of a surface patina.

Biface \#105-10. This tool is not quite complete with damage at the extreme ends (Figure 6-23). Both ends appear to have been blown off in the course of heat exposure. In addition, one lateral edge is missing due to indeterminate breakage. The material has an ashy gray appearance, likely the result of surface patination. Although, the original material color is obscured, this tool was probably fashioned from Edwards chert.

Biface \#136-10. This specimen is the lateral edge of a biface that was detached as a result of manufacturing error. It appears that in the course of bifacial thinning, the precursor (i.e., billet) struck the biface too far in from the targeted edge platform, resulting in the production of a large bulbous flake which most left a large concavity along the biface. This error was prominent enough that it may have resulted in biface abandonment.
The material is a beige-tan color, probably Edwards chert.

In summary, the mean width of the biface group is $27.41 \mathrm{~mm}$ and the average thickness is $9.01 \mathrm{~mm}$. The standard deviation of biface widths across all specimens, the planar tool dimension least affected by fragmentation, is $2.44 \mathrm{~mm}$. Biface thickness measurements represented, have a standard deviation of $2.56 \mathrm{~mm}$. This narrow range in biface size may be indicative of consistency in the size of raw material packages (i.e., cobble size). It is also possible that the biface size variance may have been functionally related, but to determine this would require further examination of microwear on a larger sample of bifaces from this site.

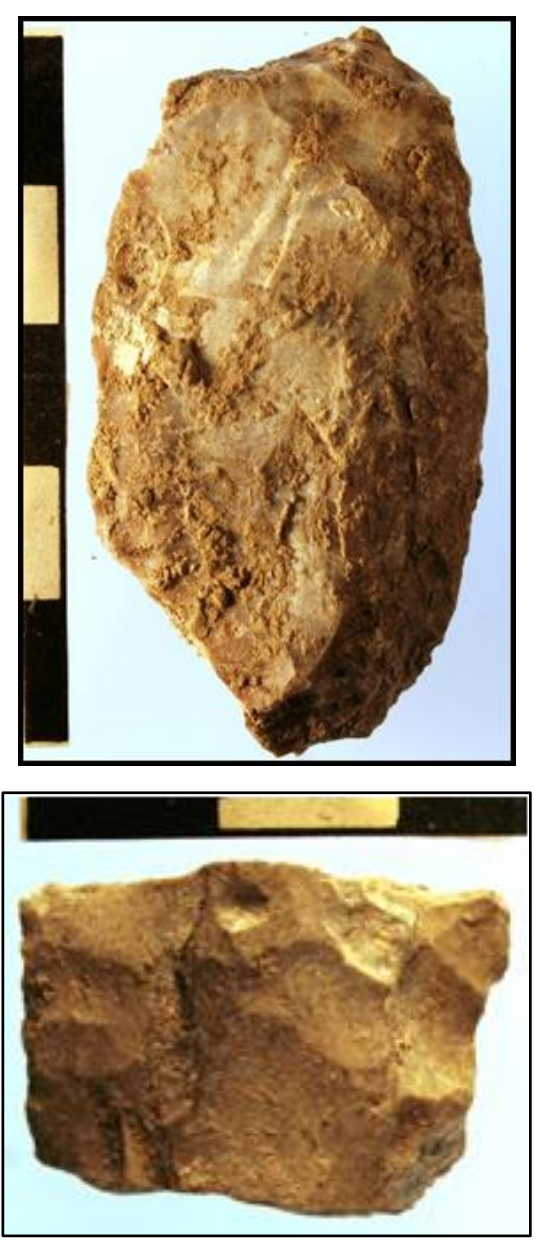

Figure 6-23. Bifaces recovered from $41 \mathrm{MM} 382$. 
As a group, these bifaces reveal random flaking patterns, indicating an expedient or nonstandard reduction sequence. As mentioned above, Callahan (1979) provided a classification scheme for bifaces recovered from Paleoindian contexts, in which he used width-to-thickness ratios to determine biface reduction stages. In general, the preparation and reduction scheme for specimens included in Callahan's studies are more complex than what was observable in the much smaller sample of bifaces from 41MM382. Half the bifaces were classified as Stage 3, with one at Stage 2, and one at Stage 4. Callahan's study, however, is probably not comparable, given the extremely limited sample size from 41MM382.

Breakage of bifaces may have occurred during manufacture, use, or postdepositionally. By examining the break areas on each specimen, it was determined that at least one of the bifaces (\#136-10) was broken during manufacture.

\subsubsection{Scrapers}

Scraping tools are typically unifacially worked and have steeply flaked working edges. Only a single specimen is present in the tool assemblage. It is thought that tools fashioned in this manner were used to scrape and prepare animal hides. This scraper (\#37-10) was recovered from 70 to $80 \mathrm{cmbs}$ in TU 1. It is irregular in form with one small edge steeply flaked (Figure 6-24; Table 6-7).

\subsubsection{Edge-Modified Flakes}

Twenty-two edge-modified (EM) flakes were recovered and are considered informal tools that were most likely produced, used, and discarded onsite. This group is the largest chipped stone tool class, composing 73 percent of the chipped stone tool assemblage. Typically, these are informal tools comprised of flakes that were not altered to a degree that significantly changed the shape and/or form of the original flake blank. In most instances, these flakes or parts of flakes have minimal, but discernible edge scaring, flaking, or rounding.
These informal tools show considerable variability in size (see Table 6-7). Edge angles measured for each modified edge were fairly consistent, with medians of 45 to 50 degrees and standard deviations of 5 to 7 degrees, respectively. These values indicate that most edge-modified flakes were subjected to similar types and intensities of modification.

All 22 specimens were fashioned from Edwards chert. These raw materials were most likely gathered from nearby before being reduced on-site. The high incidence of cortex on the dorsal face in this class is a direct result of flake removal from a cobble core. Because of generally small cobble sizes, a large number of flakes exhibit only remnants of the outer cortical surface.

Interestingly, 36 percent exhibit thermal alteration in the form of color changes and pot lidding. This is a much larger percentage than in any other tool class. However, as noted earlier, Edwards chert is a high-grade material that does not usually require heat treatment prior to flaking, as the fracture predictability is already high. Likely the thermal alteration occurred post-use as these expedient tools were discarded, or otherwise accidentally incorporated into the fires of heating elements.

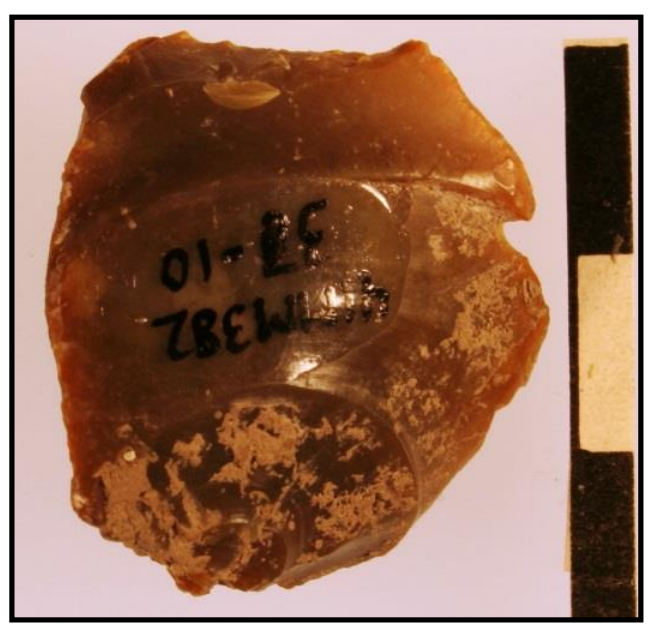

Figure 6-24. Scraper \#37-10 recovered from TU 1, Level 8 . Scale in $\mathrm{cm}$. 
Table 6-7. Selected Scraper and Edge-Modified (EM) Flake Attributes.

\begin{tabular}{|c|c|c|c|c|c|c|c|c|c|c|}
\hline PNUM & $\begin{array}{c}\text { Test } \\
\text { Unit }\end{array}$ & Level & $\begin{array}{c}\text { Depth } \\
(\mathbf{c m b s})\end{array}$ & Tool Type & $\begin{array}{c}\text { Length } \\
(\mathbf{m m})\end{array}$ & $\begin{array}{c}\text { Width } \\
(\mathbf{m m})\end{array}$ & $\begin{array}{c}\text { Thickness } \\
(\mathbf{m m})\end{array}$ & $\begin{array}{c}\text { Wt } \\
\mathbf{( g )}\end{array}$ & $\begin{array}{c}\text { Material } \\
\text { Type }\end{array}$ & $\begin{array}{c}\text { Thermal } \\
\text { Alteration }\end{array}$ \\
\hline $37-10$ & 1 & 8 & $70-80$ & Scraper & 28.35 & 25.8 & 11.66 & 7.9 & chert & no \\
$50-10$ & 1 & 12 & $110-120$ & EM Flake & 50.64 & 20.77 & 10.65 & 8.7 & chert & yes \\
$35-10$ & 2 & 8 & $70-80$ & EM Flake & 32.89 & 17.92 & 6.51 & 3.1 & chert & yes \\
$16-10$ & 3 & 4 & $30-40$ & EM Flake & 29.70 & 16.09 & 3.69 & 1.6 & chert & no \\
$29-10$ & 3 & 7 & $60-70$ & EM Flake & 34.11 & 24.65 & 6.67 & 4.4 & chert & yes \\
$32-11$ & 3 & 8 & $70-80$ & EM Flake & 15.48 & 25.63 & 4.82 & 2.3 & chert & yes \\
$32-10$ & 3 & 8 & $70-80$ & EM Flake & 56.51 & 47.44 & 13.42 & 30.5 & chert & no \\
$40-10$ & 3 & 10 & $90-100$ & EM Flake & 26.34 & 22.56 & 6.25 & 2.7 & chert & yes \\
$65-10$ & 6 & 6 & $50-60$ & EM Flake & 16.95 & 31.98 & 5.82 & 2.2 & chert & no \\
$86-10$ & 6 & 7 & $60-70$ & EM Flake & 29.40 & 16.89 & 4.55 & 1.9 & chert & no \\
$101-10$ & 7 & 6 & $50-60$ & EM Flake & 15.95 & 13.07 & 2.78 & 0.6 & chert & no \\
$143-10$ & balk & - & 103 & EM Flake & 24.69 & 23.15 & 5.38 & 3.3 & chert & no \\
$130-10$ & 8 & 11 & $100-110$ & EM Flake & 19.23 & 31.76 & 11.13 & 4.6 & chert & yes \\
$73-10$ & 9 & 8 & $70-80$ & EM Flake & 27.95 & 35.46 & 4.85 & 3.6 & chert & yes \\
$89-13$ & 9 & 12 & $110-120$ & EM Flake & 26.80 & 31.79 & 6.96 & 3.8 & chert & no \\
$89-10$ & 9 & 12 & $110-120$ & EM Flake & 32.80 & 26.93 & 9.13 & 4.9 & chert & no \\
$89-11$ & 9 & 12 & $110-120$ & EM Flake & 32.54 & 12.97 & 4.82 & 1.8 & chert & no \\
$89-12$ & 9 & 12 & $110-120$ & EM Flake & 26.29 & 21.31 & 6.57 & 2.8 & chert & yes \\
$113-10$ & BT7 & - & $113-118$ & EM Flake & 62.40 & 26.37 & 4.40 & 5.4 & chert & no \\
\hline
\end{tabular}

\subsubsection{Lithic Debitage}

Analysis of lithic debitage, the byproducts of stone tool production, is an extremely informative means of defining certain patterns of human behavior (Andrefsky 1998). Attributes that can be documented within a debitage assemblage may be used to highlight trends that provide insight into resource procurement strategies, tool production locations, material reduction strategies, tool production techniques, and tool maintenance. The lithic debitage assemblage from 41MM382 $(N=$ 1,582) consisted of platform bearing flakes, distal flakes/shatter/angular debris, and cores.

A sample of the lithic debitage assemblage $(N=$ 360) was analyzed for this report to provide a general characterization of the debitage. This analyzed sample composed the entirety of debris recovered from Level 7 in TU 9. This nonrandom sample was chosen because it appeared to represent a single component with a large concentration of material. This debitage analysis is presented in the following paragraphs.

The majority of the debitage from the analysis sample $(N=218 ; 61$ percent) falls within the 6.4 to $12.8 \mathrm{~mm}$ size range (Figure 6-25). The second most abundant size group is less than $6.4 \mathrm{~mm}(N=67 ; 19$ percent) with the next most abundant size, in the 12.8 to $19.0 \mathrm{~mm}$ range, $(N=61 ; 17$ percent $)$. This indicates a high proportion of smaller flakes were produced, suggesting a greater emphasis on finishing and resharpening activities, and/or the use of small cobbles.

Of the platform bearing flakes ( $N=65 ; 46$ percent), a moderate to high frequency exhibit thermal 
alteration ( $N=40 ; 24$ percent) (Figure 6-26). The most obvious thermal alteration occurs in the form of potlid marks (saucer-shaped divots) and thermal breaks. These are signs that heating probably occurred unintentionally, after discard. Purposeful and/or intentional heating of new material to improve quality for knapping would have involved removal from the heat source before such detrimental alterations could occur. Edwards chert is of higher quality than locally available quartzite, being a very fine-grained material that is quite suitable for knapping without heating.

The breakdown of platform types is depicted in Figure 6-27. Of the platform bearing assemblage, nearly 39 percent $(N=64)$ exhibit multifaceted platforms (i.e., faceted plus complex groups). These flakes originate from more intensively modified objective pieces (e.g., bifaces or cores with cortical or prepared platforms). Flat striking platforms represent 19 percent $(N=31)$ of the platform bearing assemblage. Flat platform flakes were detached from nonbifacial tools or planar, unmodified core surfaces (Andrefsky 1998:94; Whittaker and Kaldahl 2001:54). Crushed platforms comprise 11.5 percent $(N=19)$ of the flake assemblage. Approximately 31 percent $(N=$ 51 ) of the platform bearing flakes are cortical (Figure 6-27), representing initial flake detachment from a cortex-covered objective piece (e.g., a rounded river cobble). This is a relatively large portion (second largest platform group) and reflects the use of small locally available chert cobbles.

Lithic debitage with evidence of cortex on the dorsal face signifies early-stage reduction of objective pieces (Figure 6-28). A large portion $(N=$ $100 ; 61$ percent) of the platform bearing flakes exhibit cortex. The most likely explanation of this high incidence of cortex is that the initial reduction of raw material packages was done on-site with small chert cobbles. Therefore, most knapping of raw material appears to have focused on earlierstage reduction resulting in the production of flakes with dorsal cortex.

\subsubsection{Summary of Lithic Debitage Analyses}

The lithic debitage reveals clear patterns of local raw material procurement, reduction, and biface and flake tool production at 41MM382. The apparent exclusive presence of Edwards chert in this assemblage suggests it was locally available for tool production and intensively used.

The high incidence of cortex on platform bearing flakes and edge-modified flakes suggests on-site reduction of material. These raw material packages may have been gathered locally from nearby upland sources (2 to $3 \mathrm{~km}$ to the north) such as those sampled by Frederick (see Chapter 5.0) and/or along the San Gabriel River.

Furthermore, the high proportion of thermal alteration in the debris does not appear to represent a method for material quality improvement as material was naturally fine-grained with an appreciable isotropic character. Instead, this presence may be better explained by examination of burned rock specimens at the site as they are almost entirely composed of chert cobbles (see 6.6.4 Burned Rock section below). In fact, the initial field estimates of debitage frequencies found throughout 41MM382 may be somewhat exagerated due to the large incidence of chert cobbles/gravels used as burned rock.

The large proportion of platform bearing flakes with two or more facets (39 percent) indicates that bifacial thinning and edge resharpening and/or rejuvenation were the primary source of the flakes produced on-site. Core reduction is also indicated at this component by the presence of platform bearing flakes with only a single facet or cortical surfaces. Therefore, both bifacial and core forms were reduced on-site. However, it is unclear by strictly examinating the platform bearing flakes what proportion of bifacial reduction flakes originate from bifacial cores as opposed to modification of large flakes. 


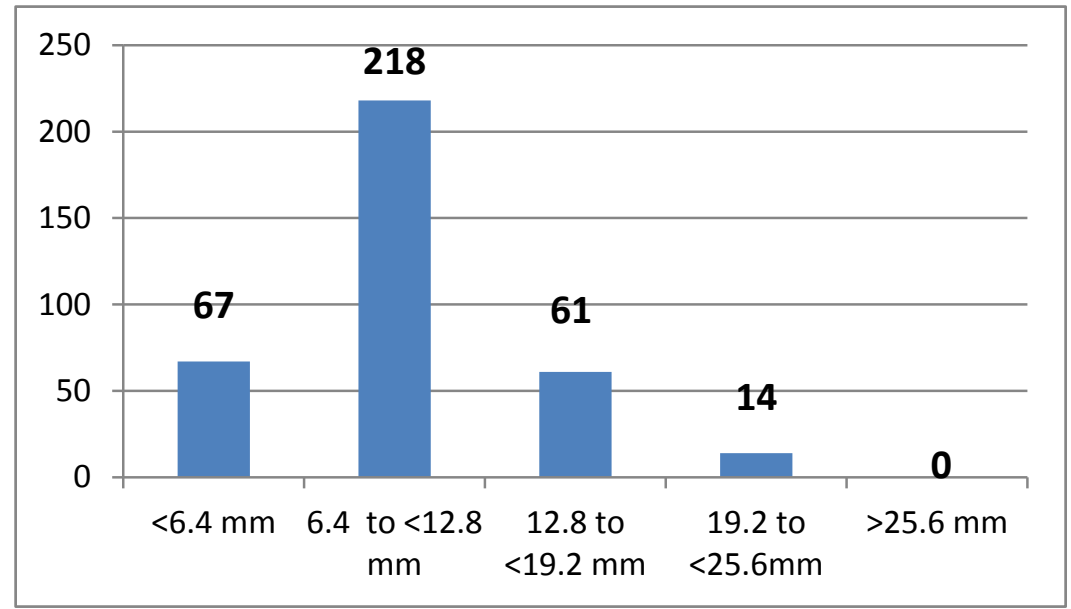

Figure 6-25. Size grade distribution of TU 9 lithic debitage sample.

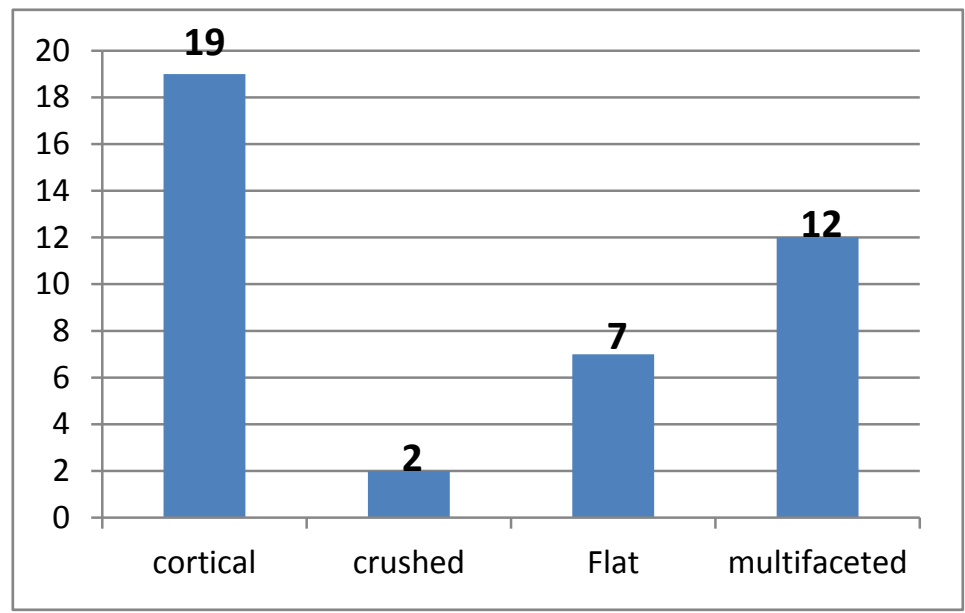

Figure 6-26. Distribution of platform bearing flakes exhibiting thermal alteration

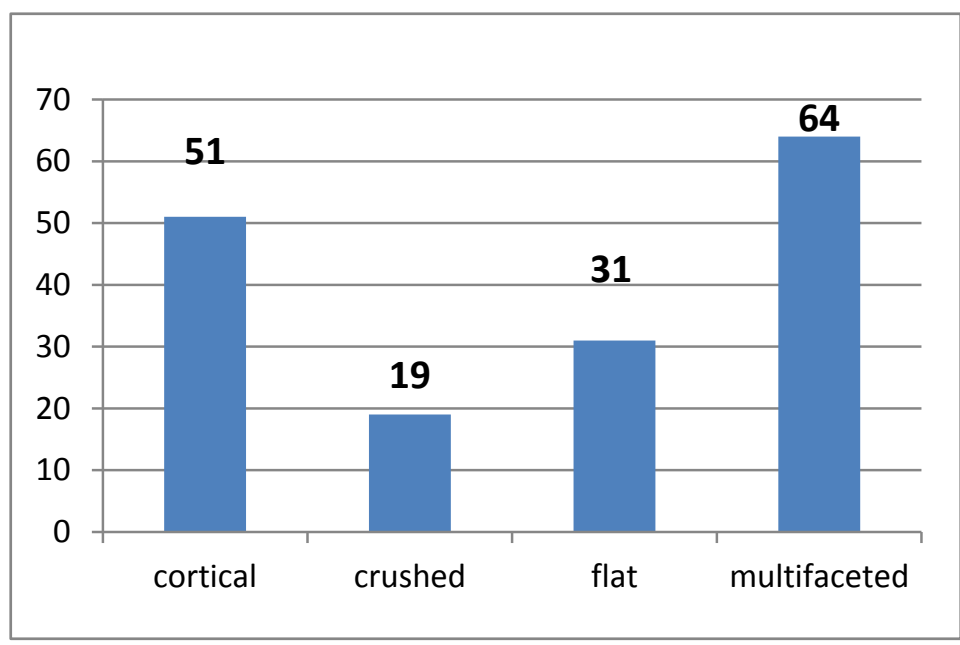

Figure 6-27. Frequency of platform bearing flake types in TU 9 sample debitage assemblage 


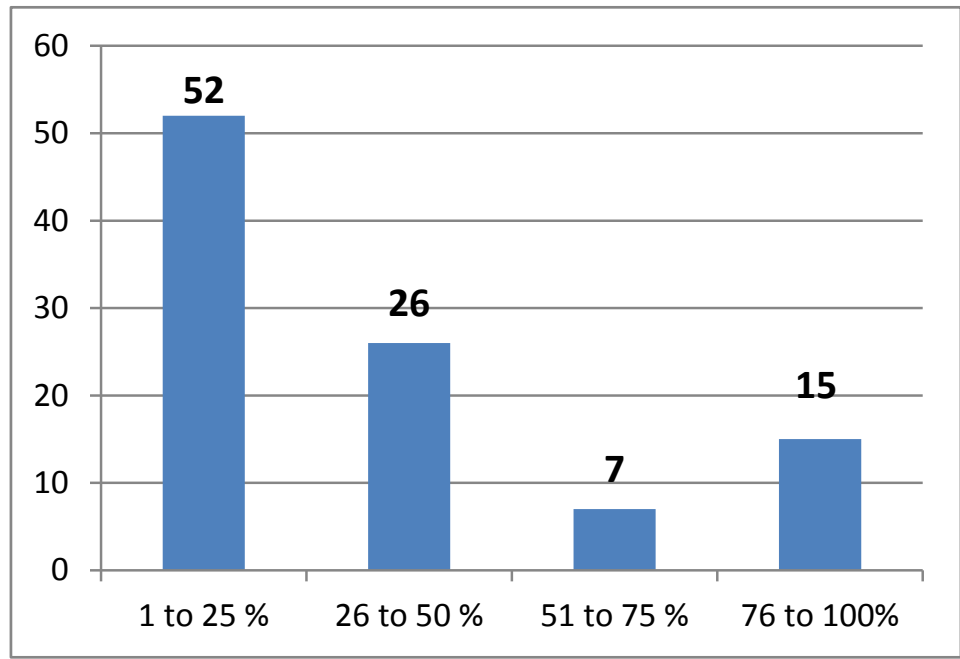

Figure 6-28. Cortex presence on lithic debitage from TU 9 sample analysis.

\subsubsection{Mussel Shells}

Mussel shells were the third most abundant artifact class $(N=251$ or nearly 8 percent of total $)$ represented (see Table 6-2). Mussel shells do not exhibit rounding, abrasions or wear indicative of extensive water transport. Almost all shells that are more or less complete are less than $3 \mathrm{~cm}$ in diameter. Very few specimens are complete with many examples of fracturing along growth lines, leaving the outer shell separated from the umbo. The fragmented nature may in part reflect how the shells were extracted from a hard clay matrix during hand-excavations using picks and shovels. However, many of the larger pieces also show previous damage along one side of the valve. Combined with the likely prehistoric heating/cooking of these shells and the subsequent wetting and drying cycles they have likely been subjected to over time, most shells are in poor condition. Very few pieces, roughly 10 to 12 (less than 5 percent) reveal visual signs of having been directly in a fire, with dark gray discolored areas. These apparently burned pieces were in at least Levels 9 through 15 in five different TUs. Test Unit 7 yielded the highest frequency of dark gray shells, from 100 to $150 \mathrm{cmbs}$. Nearly all shells were discovered in general scatters with only Feature 1 revealing more or less a concentration. No obvious piles, dumps, or lenses of shells were identified. Nevertheless, the entire shell assemblage is considered to reflect human collection, use, and discard. Inspection of this assemblage revealed no obvious signs of drilled holes, rounding of edges from use, or alterations to produce ornaments. Consequently, it is likely that all the shells were byproducts of human collection for their meat.

Shells occurred from roughly 60 to $160 \mathrm{cmbs}$ in various quantities. Most levels yielded less than 10 umbos with the highest frequencies between 130 and $150 \mathrm{cmbs}$ in TU 3 with over 60 umbos.

General inspection of the small highly fragmented shell teeth and hinges indicate that at least five species are represented. Identifications were based on hinge and teeth characteristics using the TRC mussel shell comparative collections. The smooth pimpleback (Quadrula houstonensis) appears most common and widely distributed species. Also represented in low frequencies are threeridge (Ambelma plicata), pistolgrip (Triligonia verrucosa), southern Mapleleaf (Quadrula apiculata), and possibly false spike (Quincuncina mitchelli) (Howells et al. 1996). 


\subsubsection{Burned Rocks}

Burned rocks were the second most frequent class, accounting for 38 percent $(N=1200)$ of all materials recovered. Burned rocks were all less than $10 \mathrm{~cm}$ in length, and most were less than $4 \mathrm{~cm}$. These pieces were from large pebbles and/or small cobbles. A very high percentage consists of burned chert clasts. The chert pieces exhibit sharp and irregular edges due to heat fracturing, some blocky, some with pot lids and heat spalls (Figure 6-29). Chert is an unusual choice as a stone for transference of heat, as it tends to explode when heated to high temperatures or when it is subjected to rapid/extreme temperature changes, as when a heated rock is placed in water. The relatively small size of all complete or nearly complete cobbles/pebbles is an indication that the inhabitants had limited access to larger rocks. The heat fragmented chert pieces are difficult to distinguish from knapping debris.

Chert was obviously the most common rock in the vicinity of this site, and was available in relatively small sizes from both the stream terraces immediate along the margins of the river and the higher Pleistocene fluvial gravel deposits west of the site, both north and south of the San Gabriel River
(Barnes 1981). The authors do not know if this river has accessible gravel bars that might contain rock as well. The lower terraces contain a variety of rocks including but not limited to dolomite, limestone, chert, quartz, and various igneous and metamorphic rocks from the Llano Uplift region and the Edwards Plateau. The higher upland gravel deposits are commonly exposed on the surface and contain similar rock types (Barnes 1981).

A number of complete pebbles were also recovered and most came from zones with cultural materials, indicating the pebbles were brought onto the site and are not a natural occurrence in the alluvial sediments (Figure 6-30). It appears that the small cobbles were used as hot rocks, but had not fractured from use. The nonfracturing would indicate that they had not been subjected to extreme heat or suffered from thermal shock. Most pieces were less than $7 \mathrm{~cm}$ in length. Some broken nonchert pebbles exhibit hackled edges, indicating that they were fractured in a stone boiling process (Jackson 1998:103; McParland 1977).

Twenty burned rock fragments were selected for starch grain analysis in anticipation that positive results would provide indications of plant resources cooked with the use of these rocks. The selection

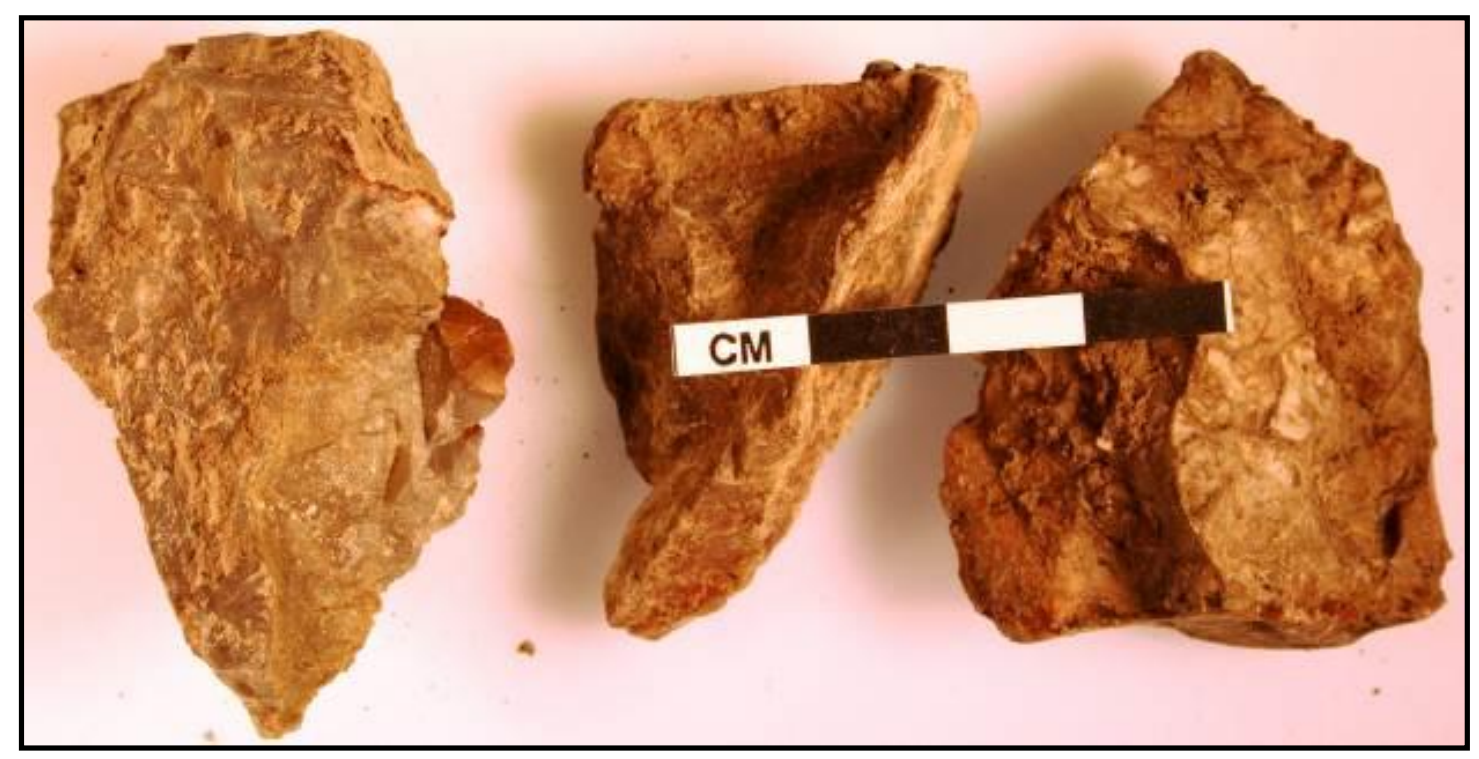

Figure 6-29. Three examples of unwashed burned chert depicting size and angularity. 


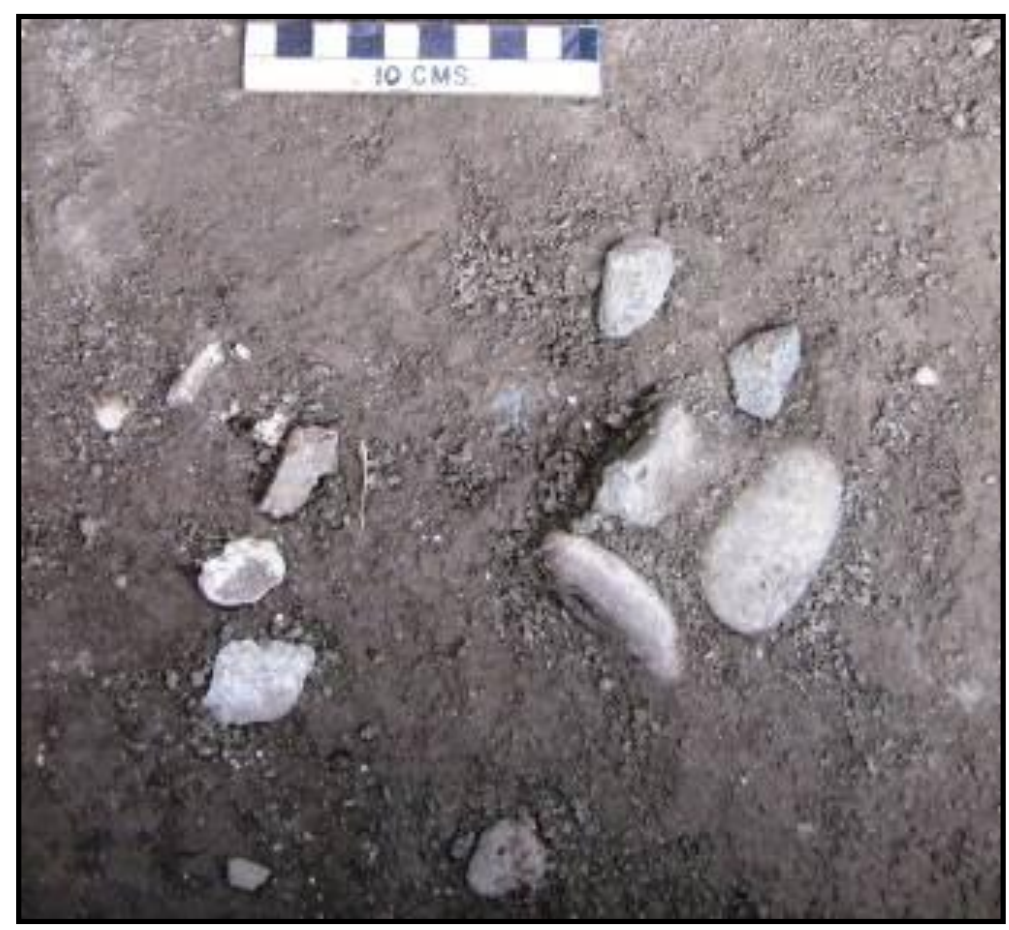

Figure 6-30. Plan view of in situ cluster of small cobbles and large pebbles used as hot rocks at $140 \mathrm{cmbs}$.

took into account the three vertical peaks of material discussed above to sample the three identifiable site components. Both chert and nonchert pieces were selected. The selection was biased towards the larger pieces in hopes of greater results (Table 6-8). The starch analysis yielded no starch grains on any of the pieces submitted (Appendix B).

\subsubsection{Snail Shells}

Hand-excavations yielded an assortment of kinds and sizes of snail shells. The largest shells are Rabdotus sp. The general habitat for Rabdotus species is a semi-arid, open environment leading to Rabdotus being referred to as the "prairie snail" (Allen and Cheatum 1961:301). In a visual scan of the Rabdotus shells collected, it is apparent that multiple sizes exist and represent adults, subadults, and juveniles. Groups of adult Rabdotus shells from single proveniences were selected and used for radiocarbon dating. These five grouping of shells were at the same depths as the sediment samples collected and sent for dating to corroborate the bulk sediment humate dates. The very apexes of the shells were removed prior to submittal for radiocarbon dating. A sample of the Rabdotus shells will be curated for future reference.

Many much smaller snail shells were present and collected, and include Polygyra and Oligyra sp. and likely other species such as Helicinidae sp., and Anguispira alternata (Allen and Cheatum 1961). None of these species are considered cultural and are assumed to be naturally present.

\subsubsection{Animal Bones}

Only 14 tiny pieces of faunal bone and one mostly complete horse metapodial were recovered (Table 6-9). The horse metapodial (226 g) was at $55 \mathrm{cmbs}$ from the very south end of BT 3 and is thought to be of historic age and not associated with any of the prehistoric occupations. The remaining 13 fragments are quite small (total of $9.2 \mathrm{~g}$ ) with the largest roughly $5 \mathrm{~cm}$ long and weighing $6.9 \mathrm{~g}$. That piece is a ca. $8 \mathrm{~mm}$ thick long bone shaft from the backdirt of BT 2 
Table 6-8. Data on Burned Rocks Selected for Starch Analysis.

\begin{tabular}{|c|c|c|c|c|l|}
\hline $\begin{array}{c}\text { Test } \\
\text { Unit No. }\end{array}$ & $\begin{array}{c}\text { Depth } \\
\text { (cmbs) }\end{array}$ & PNUM & $\begin{array}{c}\text { Weight } \\
\text { (g) }\end{array}$ & Material & \multicolumn{1}{|c|}{ Comments } \\
\hline 1 & $140-150$ & $68-1$ & 54 & Chert & angled interior \\
\hline 3 & $80-90$ & $36-1$ & 23 & $?$ & very hackled \\
\hline 5 & $80-90$ & $84-1$ & 32.5 & $?$ & partially hackled edge \\
\hline 5 & $150-160$ & $132-1$ & 75 & $?$ Quartzite & \\
\hline 6 & $110-120$ & $97-1$ & 24 & Chert & outside and inside hackled \\
\hline 6 & $140-150$ & $118-1$ & 49 & Chert & very jagged \\
\hline 8 & 132 & $104-1$ & 258 & Chert & Cobble, 1 end hackled \\
\hline 9 & $80-90$ & $76-1$ & 331 & ?Quartzite & Cobble with possible worked end \\
\hline 9 & $110-120$ & $89-1$ & 18 & Quartzite & Spall \\
\hline BT-7 & $100-110$ & $117-1$ & 109 & Chert & Nearly intact \\
\hline
\end{tabular}

Table 6-9. Data on Bone from Barrett Site (41MM382).

\begin{tabular}{|c|c|c|c|c|c|}
\hline PNUM & $\begin{array}{c}\text { Test Unit } \\
\text { No. }\end{array}$ & Depth (cmbs) & Element & Weight (g) & Comments \\
\hline 1 & BT 3 & 55 & Horse metapodial & 226 & Historic \\
\hline 24 & BT 2 & Backdirt & Long bone & 6.9 & 8 mm thick \\
\hline 52 & 2 & $110-120$ & Rodent & 0.1 & \\
\hline 41 & 2 & $80-90$ & Unknown & 0.1 & \\
\hline 63 & 4 & $140-150$ & Unknown & 0.2 & Burned \\
\hline 87 & 6 & $70-80$ & Unknown & 0.8 & \\
\hline 90 & 6 & $90-100$ & Unknown & 0.1 & \\
\hline 110 & 6 & $120-130$ & Unknown & 0.3 & \\
\hline 124 & 7 & $110-120$ & Unknown & 0.1 & rounded margins \\
\hline 126 & 7 & $130-140$ & Unknown & 0.1 & small tooth root \\
\hline 83 & 9 & $100-110$ & Unknown & 0.1 & rounded margins \\
\hline 93 & 9 & $120-130$ & Unknown & 0.4 & \\
\hline 127 & 7 & $140-150$ & Tooth fragment & 0.8 & C14 dated \\
\hline 128 & BT 7 & 130 & Unknown & 0.1 & C14 dated \\
\hline
\end{tabular}


This page intentionally left blank. 


\subsection{SUMMARY AND CONCLUSIONS}

J. Michael Quigg

The NRHP site eligibility/assessment investigations were conducted at the Barrett site (41MM382) in May 2012 by TRC. The investigations consisted of the mechanical excavation of four trenches (ca. 42 linear meters) plus $11.4 \mathrm{~m}^{3}$ of hand-excavations in 9 test units (each 100-by-50 cm), to a depth of roughly 160 cmbs across the APE as defined by TxDOT, plus initial geoarcheological assessment of the natural deposits.

The geoarcheological investigations revealed the site was within a flood basin facies of the San Gabriel River, and exhibited a similar but very subtle stratigraphic sequence, which consisted of two natural stratigraphic units informally described as the Upper Alluvium and the Lower Alluvium. A third deposit, revealed at the very southern end of BT 3, is a modern introduced fill that forms a road embankment perpendicular to the highway. No evidence exists of large magnitude flooding within these deposits. Prehistoric cultural material was observed near the base of the Upper Alluvium and within the Lower Alluvium, and the prehistoric occupations appear to extend below the base of test excavations. Multiple occupation surfaces appear present. Although a few pieces of cultural material were observed in vertical orientations, there appears relatively little postdepositional disturbance of the cultural deposits. Although clayey, none of the soils observed exhibited obvious vertic tendencies (in the form of pressure faces or slickensides). In summary, the spatial integrity appears high and the stratigraphic integrity is moderate.

The excavations yielded some 3,123 artifacts dominated by lithic debitage (49 percent) and burned rocks (38 percent) with limited mussel shells (8 percent), and only eight formal chipped stone tools that include three diagnostic projectile points. One diagnostic was of the Pedernales type, which is most abundantly found to the west in the Edwards Plateau area of central Texas. The other two are tentatively identified as Morrill points, a type that is geographically linked to east-central and east Texas (Turner et al. 2011:139). We believe that the presence of these two approximately contemporaneous types, primarily representative of different geographical regions, may reflect the use of the Blackland Prairie as a joint use area by groups from different regions during the Late Archaic I period, analogous to the situation posited for the region in later phases of prehistory. Thus, the site may hold the potential to elucidate the time depth of the emergence of use periods or cultural boundaries in this part of Texas.

The site lacked relatively well-defined features and exhibited poor preservation of organic materials such as wood charcoal and faunal bones, although a few pieces of the latter class were recovered. The absence of starch grains on the few sampled burned rocks is puzzling and potentially significant. If preservation accounts for their lack that is one thing, but if the absence is due to the lack of cooking starchy plants by the occupants that is completely different. Since starch grains have been identified in nearly all previously analyzed burned rocks across Texas thus far, it is quite likely that starchy plants were not cooked at this location. However, bulbs growing across this reg0ion such as of eastern camas (Camassia scilloidies) rain lily (Cooperia drummondii), and onions (Allium sp.) do not produce diagnostic starch grains so those potential food resources might have been used, but are not detectable through starch analysis.

Twelve radiocarbon dates from noncultural materials (6 humates, 5 Rabdotus shell clusters, and 1 bone) indicate the deposits contain cultural materials that represent roughly a 1,500 year period from about 2500 to 3900 B.P. Culturally this relates to the general Late Archaic I period, according to the central Texas chronology presented by Johnson and Goode (1994) and Collins (2004) (previously 
considered the Middle Archaic Prewitt's [1981 and 1985] chronology). The vertical distribution of the materials revealed three primary peaks in density that likely represent at least three different occupational episodes or temporally distinct cultural/chronological components.

The Barrett site data reveals a basic stratigraphy that is indicated by an absence of evidence for significant postdepositional disturbances. The geoarcheologist identified a consistent stratigraphy that has internal integrity across the investigated area with spatial integrity of cultural materials. The Barrett site has a discernible site structure as evidenced by variations in the artifact class frequencies across horizontal space. Moreover, the site has yielded what appears, based on the currently limited data, to be a temporally discrete artifact assemblage from a poorly known and limited study time period, ca. 2500 to 3900 B.P.

The presence of moderately abundant mussel shell across the lower part of the stratigraphic profile reflects at least one aspect of prehistoric human subsistence. This, perhaps in combination with the burned rocks, indicates that the heating/cooking of mussels was one task conducted. The lithic debitage indicates the use of local upland and/or river deposited gravels and also reflects a broad range of knapping activities during the various occupations. The lack of starch grains on a sample of 10 burned rocks failed to identify microfossils, which might reflect only the heating/cooking of mussels and/or nonstarchy plants.

The lower peaks of material or components are likely to yield spatial remains of activity areas indicative of food processing, artifact manufacture and maintenance activities, combined with discard of waste products from these activities. This would allow for insights into group behaviors and adaptation at this critical time period. The repetitive nature of the materials from the multiple occupations indicates continued reuse of this particular site over time and may reflect short-term focused resource gathering events.

As mentioned above, the two recognized and identified projectile point types (i.e., Pedernales and Morrill) within the cultural deposits sampled, provides a generalized representation of use periods and cultural backgrounds of the populations at this location. If the typology is correct, the Pedernales point is primarily a central Texas type, whereas the Morrill type is more prevalent in eastern Texas (Prewitt 1995:121; Turner et al. 2011:139). This may indicate that multiple populations from different regions were exploiting the same food resources at/from this location.

As Mahoney et al. (2003:20) point out, site assessments/testing and data recovery efforts have been conducted on only a small number of sites in the region, and with a few exceptions the archeological investigations within Milam and surrounding counties have tended to concentrate on upland and upland-margin settings. For the most part, those authors determined that sites of earlier periods (i.e., Paleoindian, Early Archaic and Middle Archaic) are scarce. The more numerous later sites, of Late Archaic age sites and younger, tend to yield only low densities of materials, small and few features, and only scattered burned rock. Generally, faunal and macrobotanical preservation is poor, and thus there tends to be a scarcity of dateable materials (Mahoney et al. 2003:20). In light of these factors, it appears that the Barrett site is quite representative of those gross aspects of the region of east-central Texas. Further investigations at this site should provide increased insight into both local adaptations and broader inter-regional patterns of population distribution/movement during the Late Archaic I period. 


\subsection{SITE RECOMMENDATIONS}

\section{J. Michael Quigg}

Cultural resource assessment of the Barrett site (41MM382) within the TxDOT defined APE in western Milam County was conducted to comply with existing federal and state guidelines (Antiquities Code of Texas of 1977 [revised 1987], Title 9, Chapter 191, VACS, Art. 6145-9) to assess the values of the cultural remains across the APE to make contributions to the body of knowledge of Texas prehistory and to make recommendations to the sites' eligibility to National Register of Historic Places (NRHP) and as a State Antiquities Landmark (SAL). These investigations were necessitated by the planned replacement of two bridges and an associated ROW realignment by TxDOT.

According to the National Historic Preservation Act of 1966 (Section 106), and Federal Regulations (36 CFR 60.4) a site's significance is evaluated based on the criteria identified by the National Parks Service (1995:2). Cultural resources are eligible for listing on the NRHP and thus worthy of avoidance, protection, or mitigation through data recovery, if they are significant in American History, architecture, engineering, or cultural history. Significant properties are those that possess integrity of location, design, setting, materials, workmanship, feeling, and association and:

A. that are associated with events that have made a significant contribution to the broad patterns of our history; or

B. that are associated with the lives of persons significant in our past; or

C. that embody the distinctive characteristics of a type, period or method of construction, or that possess high artistic values, or that represent a significant and distinguishable entity whose components may lack individual distinction; or

D. that have yielded, or may be likely to yield, information important in prehistory or history.
Criterion D as defined above generally applies to prehistoric archeological sites.

The criteria for determining the eligibility of a prehistoric or historic cultural property for designation as an SAL are presented in Chapter 191, Subchapter D, Section 191.092 of the Texas Antiquities Code. These criteria are similar to the criteria used in assessing the eligibility of a property for inclusion in the NRHP:

Sites, objects, buildings, artifacts, implements, and locations of historical, archeological, scientific, or educational interest including those pertaining to prehistoric and historical American Indians or aboriginal campsites, dwellings, and habitation sites, their artifacts and implements of culture, as well as archeological sites of every character that are located in, on, or under the surface of any land belonging to the State of Texas or to any county, city, or political subdivision of the state are state archeological landmarks and are eligible for designation (Section 191.092(a)).

The archeological field assessment of the Barrett site (41MM382) consisted of trenching some 42 linear meters and the hand-excavation of $11.4 \mathrm{~m}^{3}$ of deposits that targeted mostly a zone of cultural materials between 50 and $160 \mathrm{cmbs}$ within the APE. The recovered artifacts and assessment of those artifacts and their context, they have integrity, indicates the presence of multiple components pertaining to the Late Archaic I period that are moderately well-stratified. Based on the information presented in the previous chapters TRC finds that this body of evidence is adequate to address wide ranging questions pertaining to behaviors of human groups during the periods of occupation represented in the Blackland Prairies; and therefore, recommends that the portion of the Barrett site within the APE is eligible for NRHP listing under Criterion D, 36 CFR 60.4. Furthermore, it is also recommended that this same area is eligible for SAL designation under Criteria 
1 and 2 of the Rules of practice and procedures for the Antiquity Code of Texas, 13 TAC 26.8.

Because of these apparent eligibilities and the potential for this site to yield information significant for understanding Texas prehistory, TRC recommends the examination of that portion of the Barrett site within the APE and its contents continue with the implementation of an initial research design to be presented in the following section to guide the data recovery investigations prior to any further development impacts.

\subsection{DATA RECOVERY RECOMMENDATIONS}

The Barrett site is an excellent candidate for data recovery for its potential to contribute to a variety of research issues and questions. Sites of this age, especially in the Blackland Prairie, have not often been encountered or intensively investigated. It has the potential to contribute a better understanding of this poorly documented time period (ca. 3900 to 2300 B.P.) use of local and nonlocal resources, and general paleoenvironmental conditions at this time for this specific region. An interdisciplinary approach will be used in the anticipation that varied aspects of the human behavior may be linked to the surrounding environment. The proposed initial research design is presented in the subsequent chapter for a discussion of the issues and questions. 


\subsection{RESEARCH DESIGN FOR DATA RECOVERY AT THE BARRETT SITE (41MM382): EXPLORING A LONG-TERM MAJOR CULTURAL BOUNDARY \& PALEOENVIRONMENTAL INFLUENCES}

Robert A. Ricklis

\subsection{BACKGROUND AND SITE SIGNIFICANCE}

The Barrett site (41MM382) contains evidence of multiple occupations within stratified contexts in alluvial deposits along the San Gabriel River where it crosses the Blackland Prairie. A suite of 12 radiocarbon dates was obtained during the testing of this site. Although the dated materials (humates in bulk sediment samples, Rabdotus land snail shells, and a single sample of faunal tooth) largely represent naturally occurring organics, the dated samples were extracted from depths within the hand-excavations that correspond to the arbitrary levels from which cultural materials were most abundantly present. Thus, the calibrated ranges of the radiocarbon dates are accepted as reliable, though arguably only approximate, indicators of the chronological position(s) of the recovered material culture remains.

As can be seen in Figure 9-1, the calibrated age ranges of all but one of the radiocarbon dates cluster between ca. 3000/2800 and 500 B.C. (3190 to 4090 B.P.). The oldest date (cal 3790 B.C. or 5100 B.P.) was obtained on bulk sediment humates from a level that was below the depth of the cultural debris). This corresponds well with the temporal interval identified by Johnson and Goode (1994, 1995) as the Late Archaic I. It is also the period which those authors defined as the Edwards Interval, which they identified as a period of relatively dry climate in central Texas. An important cultural corollary of the xeric conditions of the Edwards Interval on the Edwards Plateau was the relatively intensive exploitation of xerophytic plant resources that were processed (baked) through the use of hot rock cooking techniques, resulting in the formation of numerous and often massive burned rock middens during this period (Johnson and Goode 1994, 1995). The fact that the most abundant projectile point type in central Texas burned rock middens is the Pedernales point (Weir 1976), along with the fact that this type falls into the Late Archaic I period as defined by Johnson and Goode (1994, 1995), lends support to their suggestion of a correlation between intensive hot rock cooking and the Late Archaic I period and its environmental corollary, the dry Edwards Interval.

The time diagnostic lithic artifacts recovered from the Barrett site consist of three dart points representing two distinct types. One is the proximal half of a Pedernales point, and the other two are currently identified as Morrill points. As just noted, the established time range for Pedernales points is within the Late Archaic I period (i.e., ca. 2500 to 3500 B.P. [ca. 500 to 1500 B.C.]) (Turner et al. 2011:148), and it fits well with the time range indicated by the radiocarbon dates from the Barrett site (see Figure 9-1). The Morrill type is placed by Turner et al. (2011:139) in the "Middle Archaic" period, which, by their definition, ranges between ca. 3500 and 1000 B.C. The time range which brackets most of the calibrated radiocarbon dates from the Barrett site.

In short, the combined data obtained during the eligibility testing at 41MM382 indicates occupation of the site primarily during the cultural interval defined as the Late Archaic I by Johnson and Goode (1995), and one that is poorly represented across the Blackland Prairie and much of central Texas. Of particular interest and potential significance is that two of the three diagnostic artifacts from the site are Morrill dart points, a type poorly represented from central Texas, but more commonly linked with the east-central and easternmost portion of the state 


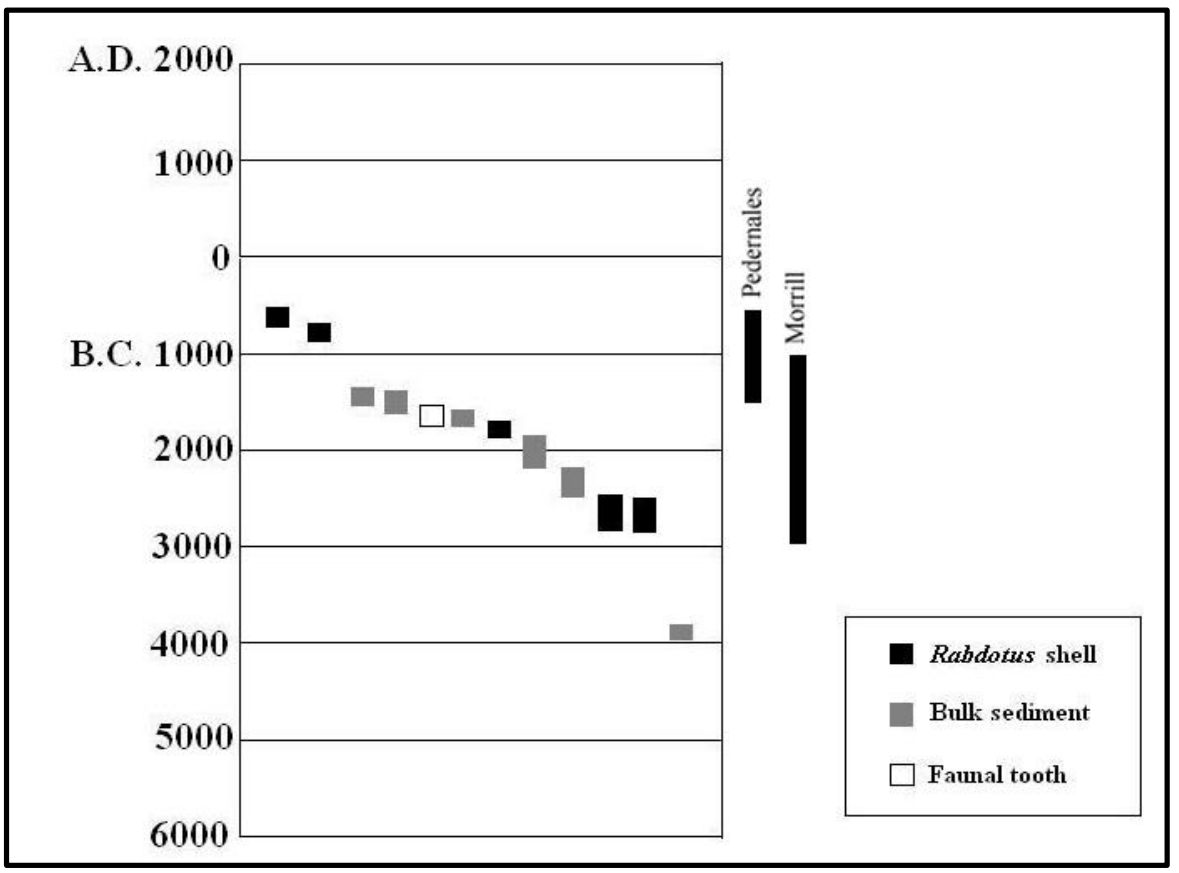

Figure 9-1. Chart showing 2-sigma calibrated age ranges of radiocarbon dates from 41MM382, as well as kinds of materials in each date sample. The estimated time ranges of Pedernales and Morrill dart points are indicated by bars to the right of the chart (based on Turner et al. 2011).

(Turner et al. 2011:139) (Figure 9-2). Thus, the cultural deposits can be assigned to the Late Archaic I period on the basis of both chronometric dating and artifact typology, and can be viewed as culturally intermediate between central and east Texas in terms of the represented point types.

\subsection{THE BARRETT SITE (41MM382) AND THE NATURE OF HUMAN OCCUPATION OF THE BLACKLAND PRAIRIE}

\subsubsection{The Question of Prehistoric Cultural Boundaries}

The idea that the north-south trending Blackland Prairie formed a boundary zone between cultural patterns in central Texas and those of east Texas is not new. In 1975, Shafer et al. suggested that the valleys of east-west flowing rivers were "riparian corridors" through which prehistoric peoples moved between these two regions. Those authors viewed the river valleys as specialized ecological zones in which human hunter-gatherers had access to a greater diversity of resources than could be found on the open prairies, per se, and thus narrow environmental zones that could sustain populations as they moved between the markedly different environments of the east Texas woodlands and the scrubby vegetated hills of the Edwards Plateau. Similarly, Brown (1989) has suggested that the Blackland Prairie environment had insufficient resources to support foraging human populations throughout and entire annual cycle.

Brownlow (2003:7) further makes the point that:

The implication is that groups might have used the riparian corridors [sensu Shafer et al. 1975] to cross the Blackland Prairie during the Late Archaic I, to expand their ranges westward onto the Edwards Plateau (or conversely, eastward to the Post Oak Savannah) but may not have felt the subsistence pressure to do so during the Late Archaic II (Brownlow 2003:7). 


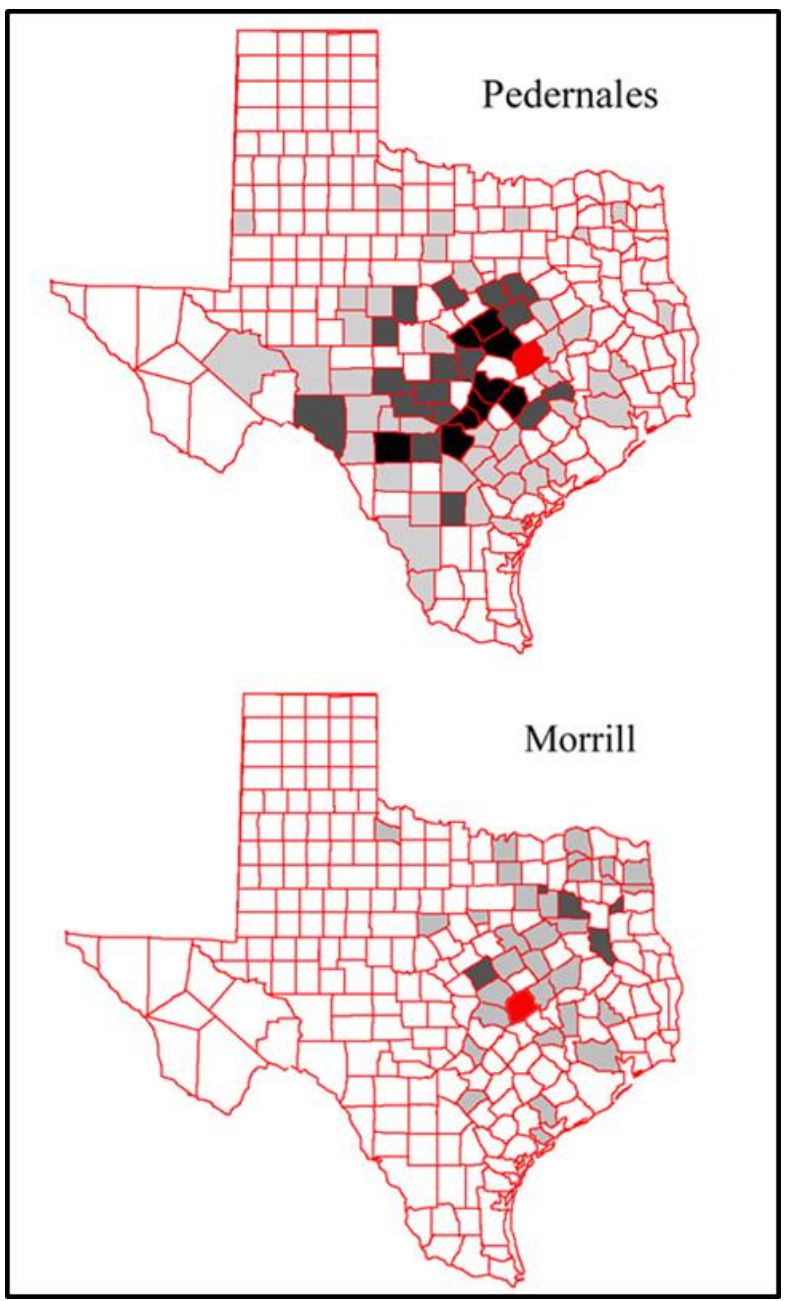

Figure 9-2. Maps of Texas counties, showing relative abundances of Pedernales and Morrill dart point by county (black $=>50$; dark gray $=11-49$; light gray $=1-10$ ). Milam County shown in red. Data from Prewitt 1995.

The notion that the Blackland Prairie marked a major cultural boundary zone has been put forth for the post-Archaic period, as well. Shafer's more recently articulated hypothesis that some portion of the Caddo populations linked culturally to the east Texas woodlands either moved westward onto the prairies to exploit bison and/or chert resources, or alternatively, engaged in direct contacts with resident central Texas hunter-gatherers for the purpose of obtaining those resources via trade once again views the prairie strip as a boundary between major cultural areas and the setting of intercultural exchange of goods and/or information (Shafer and Bryant 1976).

Recent excavations at the J. B. White site (41MM341), a location of multiple Late Prehistoric occupations along the Little River in Milam County (Gadus et al.2006), are again indicative of the kinds of cultural interactions that are posited for this major boundary zone. This site yielded several Gahagan bifaces similar to the specimens from the George C. Davis Caddo site in east Texas, as well as Alba arrow points that were also very similar to examples from elite tomb burials at the George C. Davis site (Story 1990). Data on subsistence practices at the J. B. White site point to hunting, gathering and cooking of wild bulbs, and gathering and consumption of freshwater mussels from the nearby river (Gadus et al. 2006).

It should also be noted that Frank Schambach (1998), in his definition of the "Trans-Mississippi South" (TMS), placed the southwestern most limit of this cultural-ecological region in Texas at the western margins of the Post Oak Savannah, in keeping with his definition of the region as characterized by oak-hickory forests and concomitant ecosystems. In cultural terms, the TMS was the setting of southeastern-oriented preCaddo cultural patterns, some ancestral to Caddo and some not. Schambach (1998) placed the southern limits of the TMS in east Texas and extended it to the coastal zone around Galveston Bay. More recently, Ricklis (2012) suggested that the southern limits of the TMS should be extended to include the central coastal plain of Texas to at least as far south as the San Antonio River drainage, based on the long-term recurrence of Southeastern cultural influences beginning in the Early Archaic cultural influences expressed in the large cemetery dating to ca. cal 7500 to 6200 B.P. at the Buckeye Knoll site (41VT98) in Victoria County (Ricklis 2011), and a recurrent presence of eastern Early and Middle Woodland traits in Late Archaic cemeteries at sites such as Ernest Witte (Hall 1981) and Crestmont (Hall 2002) in the lower Brazos and 
Colorado drainages somewhat farther to the north. These recurrent connections/relationships between Texas Archaic cultures and contemporaneous patterns in the Eastern Woodlands strongly suggest that the Texas coastal plain was part of a broad cultural-ecological region that Schambach subsumed under his TMS (Ricklis 2012:696-700), a past cultural reality that, once again, implies a major cultural boundary along the western margin of the Texas post oak belt and/or the eastern margin of the adjacent Blackland Prairie area. The findings made during the testing of the Barrett site suggest that this boundary existed during the Late Archaic I, a period largely unrepresented by the coastal plain mortuary traditions documented to the east, where the mentioned Late Archaic cemeteries are coeval with Johnson and Goode's (1995) Late Archaic II period.

\subsubsection{Subsistence Regimes along the Blackland Prairie Zone}

In general, the massive burned rock middens documented at Archaic sites on the Edwards Plateau and along the Balcones Escarpment are not known on the Blackland Prairie (i.e., Hays 1982; Johnson 2000; Mahoney et al. 2003; Peter et al. 1982a). While small burned rock features representing hearths and/or a variety of heating elements have been reported (e.g., Brownlow 2003; Figueroa et al. 2011; Gadus et al. 2006; Hays 1982b; Johnson 2000) and some of these are composed of small (less than $1 \mathrm{~m}$ in diameter) clusters of fire broken limestone clasts, the extensive and thick accumulations characteristic of central Texas burned rock middens are absent in this area. The Barrett site is, in fact, no exception to this rule, given that the few clusters of burned rock identified in the field were ephemeral at best, and were comprised of small clasts of fire cracked chert ranging in size from large pebbles to small cobbles. Thus, burned rocks, a class of material that is overwhelmingly abundant at sites just a few kilometers to the west, is strikingly less-well represented at 41MM382. It is not entirely clear whether this dearth of rocks represents nonavailability or raw materials (e.g., limestone from bedrock outcrops) or rather also significantly reflects a markedly different cultural-ecological pattern, one that did not rely substantially on the hot rock cooking of xerophytic plants that was a major focus on the Edwards Plateau (cf., Black and Creel 1997; Collins 1998, 2004; Prewitt 1981, 1985; Ricklis and Collins 1994; Weir 1976). Put another way, a key question is: Does the dearth of large burned rock features on the Blackland Prairie reflect merely the lack of rocks for cooking purposes? Alternatively, does it represent occupation by groups whose normal operational area included woodland environments to the east, and who used the Blackland Prairie only on a parttime (perhaps seasonal?) basis, and whose established subsistence regime did not involve the intensive plant cooking that typified groups living to the west on and along the Edwards Plateau? In one instance, the dearth or large hot rock features reflects a relatively opportunistic approach to plant processing (i.e., it was done when and where the necessary resources were available). In the other scenario, fundamental cultural differences and correlated adaptive traditions were significant causal factors.

\subsubsection{Paleoenvironmental Factors}

As mentioned above, the radiocarbon dates from 41MM382 suggest that the site was occupied during the Late Archaic I, a period that corresponded to the climatically dry Edwards Interval, as defined for central Texas by Johnson and Goode (1995). Thus, it may been the case that prehistoric folk living on and/or utilizing the Blackland Prairie may have been even more tethered to the riparian corridors (sensu Shafer et al. 1975) during this period than in earlier or later eras. If this were the case, we should expect to see relatively more evidence for the use of riverine and floodplain resources than for resources from the 
inter-fluvial prairie environment. For example, food resources such as aquatically adapted reptiles and amphibians, fish, freshwater mussels and small-to-medium sized game animals such as would have lived in moist riparian woodlands are likely to be better represented in zooarcheological assemblages than species more typically adapted to the relatively dry prairies of the interfluves. Macrobotanical samples should contain relatively abundant evidence for the remains of aquatic roots (e.g., cattail) and/or nuts such (e.g., Carya sp., Juglans sp.), all available from the region's floodplains.

Because the severity of the Edwards Interval dry climate, and its effect upon flora and fauna, and thus upon prehistoric human lifeways on the Blackland Prairie are presently unknown, we propose a series of paleoenvironmental investigations as part of the overall data recovery strategy at 41MM382. Recommended techniques include palyonogical analysis of sediments from cores extracted from near-site locations on the San Gabriel River floodplain, analysis of land snails recovered from on-site and near-site sediment columns to determine the proportional representation of environmentally indicative species such as Rabdotus, Helicina and Polygyra, phytolith analysis on samples from sediment columns from on- and near-site locations to identify fluctuations in grass communities, and stable carbon isotope analyses from on- and near-site sediment columns to assess changes in the proportional representation of $\mathrm{C}_{4}$ and $\mathrm{C}_{3}$ plants in the environs of the site.

\subsection{GOALS OF DATA RECOVERY}

\subsubsection{Hypotheses and Issues}

These are nontrivial questions concerning fairly broad patterns of Texas prehistory that we believe can potentially be addressed by data recovery work at the Barrett site. To concisely summarize, these issues are:
1. The Blackland Prairie was a north-south trending expanse of grassland with relatively narrow east-west riparian corridors, and it served as a major boundary zone between peoples adapted to the Edwards Plateau to the west and peoples adapted to the more wooded environments of east-central and east Texas. As such, it saw occupation by groups from both of those areas, but may not have been, in itself, sufficiently resource rich to provide full time subsistence opportunities to hunter-gatherer populations.

2. This boundary existed in Late Prehistoric times as the interface between agricultural Caddoan populations of east Texas and non-Caddoan hunter-gatherer populations living on the Edwards Plateau and along the Balcones Escarpment;

3. This cultural boundary had considerable time depth insofar as it existed as far back in prehistory as the Late Archaic I, ca. 3500 to 500 B.C., as represented at 41MM382.

4. Based on the evidence provided by radiocarbon dates and projectile point typology, the main occupation of 41MM382 occurred during the Late Archaic I period, ca. 3000 to 500 B.C., as defined by Johnson and Goode (1994). According to those authors, this was also the time of the Edwards Interval, a period of relatively dry climate in central Texas.

5. The Blackland Prairie, as an environmental resource mosaic, was less productive than either the Edwards Plateau or the Eastern Woodlands a factor that may have been particularly pertinent during the Edwards Interval. The Plateau provided a range of xerophytic plants, along with an abundance of limestone outcrops that provided the rocks needed for intensive processing of those plants. The woodlands provided an abundance of nuts 
such as hickory that were, in themselves, highly nutritious and storable food resources, and that also supported large populations of ungulate browsers such as whitetail deer. A relatively productive resource mosaic was restricted to the riparian corridors on the Blackland Prairies, so that this environmental zone may not have supported full time residence by relatively large/dense human populations, a factor that contributed to its long-term use as a boundary between more productive regions, and its parttime use by human groups whose adaptations were linked to those regions. Thus, at 41MM382, the data acquired during testing suggests: a) an absence of hot rock cooking as an intensive subsistence activity (as indicated by a dearth of substantial burned rock features, plus the absence of the starch grains representing plant food processing that are typically found on central Texas sites), and b) the opportunistic exploitation of freshwater mussels, a riverine resource and hunting of game that was presumably attracted to the wellwatered riparian margins (as evidenced by the presence of dart points and small fragments of poorly preserved faunal bone).

\subsection{KEY OBJECTIVES OF DATA ACQUISITION DURING DATA RECOVERY AT $41 \mathrm{MM} 382$}

The following are specific goals of the recommended data recovery:

1. Expansion of the sample of diagnostic lithic artifacts. The small $(N=3)$ sample of dart points recovered during testing indicate, as noted above, that the occupants of the site during the Late Archaic I period had generalized cultural affiliations with peoples of the central Texas Edwards Plateau region to the west and the wooded environment of eastcentral and/or east Texas to the east. This significant point requires additional empirical support in order to provide the basis for more confident inference. Specifically, it is expected that an expanded sample of points will be comprised of both central Texas types such as Pedernales and east Texas types such as Morrill and perhaps others such as Yarbrough. Given that all three of the projectile points found during testing came from the same part of the sites, it is recommended that data recovery operations involve the excavation of a substantial block of units in that area.

2. Acquisition of additional kinds of lithic tools to better define the range of activities and the kinds of materials processed/worked on-site. It is expected that tool types associated with hunting and game processing activities (e.g., knives, scrapers) will predominate, as these will support that inference that hunting was carried out and that plant processing was minimally carried out at this location. Use-wear and starch grain analysis on such lithic items is recommended to better clarify these issues. Conversely, it is expected that ground stone items that would have served in intensive plant processing activities will be scarce or not present at all.

3. Instrumental neutron activation analysis or test the application of a semiquantitative nondestructive analysis such as very near infrared reflectance spectroscopy (see geoarcheological recommendation above) on lithic items from the site, as well as on natural cherts from nearby surface sources is recommended to determine the degree to which locally gathered stone was used in the production of tools. Such analysis will also aid in determining if some tools were imported to the site from either the Edwards Plateau area of from gravel outcrops along streams to the east, with attendant elucidation of the geographic range of the peoples who occupied 41MM382. 
4. We propose to incorporate acquisition of paleoenvironmental data into data recovery work. To this end, we recommend extraction of sediment cores from natural alluvial contexts immediately adjacent to the site, analysis of fossil pollens by incremental depths within the cores, along with chronological control to be obtained by radiocarbon dating of organic fractions of the sediments at selected depth locations in the sediment cores. It is anticipated that this effort will produce a more or less detailed and accurate history of vegetation patterns within the relevant site catchment area and thus provide a useful environmental reconstruction for contextual interpretations of human adaptive behavior. We also recommend analysis of phytoliths, variability of land snail species, and shifts in stable carbon ratios through time, to be carried out on sediment samples taken from on-site and/or near-site sediment columns that will be secured during data recovery fieldwork. It is expected that these various techniques will augment, and hopefully corroborate, the paleoenvironmental data acquired from the laryngological analysis, and thus provide a reliable reconstruction of environmental trends during the middle to late Holocene, the time range that brackets the main occupation of the site.
5. Additional data on intrasite features and distributional patterns are desirable in order to reconstruct the kinds of activities carried out in a relatively nonintensive occupation of a boundary zone residential location. The small ephemeral features documented during the testing phase indicate minimally intensive heating/cooking activities; more extensive excavation can be expected to confirm whether or not this was in fact the rule here.

6. It is hoped that additional hand-excavation at the site will provide organic materials such as wood charcoal and faunal bone that can be directly linked to intact features or debris concentration, in order to radiocarbon date and thus to more precisely document the age of the various human habitations.

7. It is also to be hoped that an expanded sample of faunal material can be recovered. While the poor condition of faunal materials found during testing indicates unfavorable preservation conditions, more extensive excavations and selectively fine screening/flotation samples may provide sufficient faunal remains for at least an approximate understand of the range of taxa that were exploited. 
This page intentionally left blank. 


\subsection{REFERENCES CITED}

Abbott, J. T.

1994 Chapter 12, Geomorphic Context of the Barton Site (41HY202) and the Mustang Branch Site (41HY209). In Archaic and Late Prehistoric Human Ecology in the Middle Onion Creek Valley, Hays County, Texas, Volume 2, Topical Studies, by R. A. Ricklis and M. B. Collins, pp. 353-379. Studies in Archeology 19, Texas Archeological Research Laboratory, The University of Texas at Austin.

2003 Appendix K: Stratigraphic and Geomorphic Evaluation of Brushy Creek at FM973. In Archeological Investigations at 41WM815, A Blackland Prairie Site, Williamson County, Texas, by Russell K. Brownlow, pp. 179-191. Studies in Archeology 36, Texas Archeological Research Laboratory, The University of Texas at Austin and Archeological Studies Program, Report 23, Environmental Affairs Division, Texas Department of Transportation, Austin.

Allen, D. C. and E. P. Cheatum

1961 Ecological Implications of Fresh-Water and Land Gastropods in Texas Archeological Sites. Bulletin of the Texas Archeological Society 31:291-316.

Andrefsky, W. Jr.

1998 Lithics: Macroscopic Approaches to Analysis. Cambridge University Press, Cambridge.

Barnes, V. E.

1981 Geological Atlas of Texas, Austin Sheet. Francis Luther Whitney, Memorial Edition, Bureau of Economic Geology, The University of Texas at Austin.

Bell, R. E.

1960 Guide to the Identification of Certain American Indian Projectile Points. Special Bulletin No. 2 of the Oklahoma Anthropological Society.
Bement, L. C.

1989 Excavations at 41BP19, The Kennedy Bluffs Site, Bastrop County, Texas. Texas Department of Highways and Public Transportation, Highway Design Division, Contract Reports in Archaeology, Report Number 5, Austin.

1993 A Flexed Burial From Llano County, Texas. Bulletin of the Texas Archeological Society 61:281-287.

Black, S. L. and D. G. Creel

1997 The Central Texas Burned Rock Midden Reconsidered. In Hot Rock Cooking on the Greater Edwards Plateau: Four Burned Rocks Midden Sites in West Central Texas. Volume I, by S. L. Black, L. W. Ellis, D. G. Creel, and G. L. Goode, pp. 269-305. Studies in Archeology 22, Texas Archeological Research Laboratory, The University of Texas at Austin and Archeological Studies Program, Report 2, Texas Department of Transportation, Environmental Affairs Department.

Black, S. L., L. W. Ellis, D. G. Creel, and G. L. Goode

1997 Hot Rock Cooking on the Greater Edwards Plateau: Four Burned Rocks Midden Sites in West Central Texas. Volume I, Studies in Archeology 22, Texas Archeological Research Laboratory, The University of Texas at Austin and Archeological Studies Program, Report 2, Texas Department of Transportation, Environmental Affairs Department.

Blair, W. F.

1950 The Biotic Provinces of Texas. Texas Journal of Science 2(1):93-117.

Blum, M. D.

1987 Late Quaternary Sedimentation by the Upper Pedernales River, Central Texas. Unpublished Master's thesis, The University of Texas at Austin.

Blum, M. D. and S. Valastro, Jr.

1989 Response of the Pedernales River of Central 
Texas to Late Holocene Climate Change. Annals of the Association of American Geographers 79(3):435-456.

Bond, C. L.

1978 Three Archeological Sites at Hoxie Bridge, Williamson County, Texas. Report Submitted to the Interagency Archeological Services-Denver, Report No. 43, Texas A\&M University.

Bousman, C. B.

1998 Paleoenvironmental Change in Central Texas: The Palynological Evidence. Plains Anthropologist 43(164):201-219.

Bozarth, S. and T. Woodburn

2011 Appendix F: Paleoenvironmental Reconstruction at 41TV410 (Area-3) based on Biosilicate, Charred Phytolity, and Particulate Charcoal Analysis. In Results of Archeological Significance Testing at $41 T V 410$ and $41 T V 540$ and Associated Geomorphological Investigations on a Segment of Onion Creek in Travis County, Texas, by A. Figueroa, R. Mauldin, C. Frederick, S. A. Tomka, and J. L. Thompson, pp. 211-225. Archaeological Report No. 420, Center for Archaeological Research, The University of Texas at San Antonio and Texas Department of Transportation, Environmental Affairs Division, Archeological Studies Program, Report No. 134, Austin.

Brigham, M. S.

1977 The Geomorphic Evolution of the Bartlett Surfaces South of the Brazos River and North of the Colorado River, Central Texas. Unpublished Bachelors thesis, Baylor University, Waco.

Brownlow, R. K.

2003 Archeological Investigations at 41WM815, A Backland Prairie Site, Williamson County, Texas. Studies in Archeology 36, Texas Archeological Research Laboratory, The University of Texas at Austin and Archeological Studies Program, Report 23, Environmental Affairs Division, Texas Department of Transportation, Austin.
2004 Data Recovery Investigations at the Holt Site (41YHY341), San Marcos, Hays County, Texas. HJN 040032 AR, Prepared for Fairfield Residential, LLC, by Horizon Environmental Services, Inc., Austin.

Brown, D. O.

1989 Prehistoric Subsistence Strategies in Northeastern Central Texas. Bulletin of the Texas Archeological Society 59:201-244.

Bryant, V. M., Jr.

1977 A 16,000 Year Old Pollen Record of Vegetation Change in Central Texas. Palynology 1:143-155.

Bryant, V. M. and R. G. Holloway

1985 A Late-Quaternary Paleoenvironmental Record of Texas: An Overview of the Pollen Evidence. In Pollen Records of the Late Quaternary North American Sediments, edited by V. M. Bryant and R. G. Holloway, pp. 39-70. American Association of Stratigraphic Palynologists Foundation, Dallas.

Bush, L. L.

2006 Appendix G: Analysis of Macrobotanical Remains form 41MM341. In Data Recovery Excavations at the J. B. White Site (41MM341), Milam County, Texas, by E. F. Gadus, R. C. Fields, and K. W. Kibler, pp. 273-298. Reports of Investigations, Number 145, Prewitt and Associates, Inc., Cultural Resources Services, Austin and Archeological Studies Program, Report No. 87, Texas Department of Transportation, Environmental Affairs Division, Austin.

Byrd, C. L.

1971 Origin and History of the Uvalde Gravel of Central Texas. Baylor Geological Studies No. 20, Baylor University, Waco.

Callahan, E.

1979 The Basics of Biface Knapping in the Eastern Fluted Point Tradition: A Manual for Flintknappers and Lithic Analysts. Archeology of Eastern North America 7:1180. 
Campbell, T. N.

1948 The Merrill Site: Archeological Remains Associated with Alluvial Terrace Deposits in Central Texas. Bulletin of the Texas Archeological Society 19:71-35.

Caran, S. C.

1992 Neogene and Quaternary Stratigraphy of the Inner Gulf Coastal Plains, SouthCentral Texas. In Late Cenozoic Alluvial Stratigraphy and Prehistory of the Inner Gulf Coastal Plain, South-Central Texas. Guidebook to the $10^{\text {th }}$ Annual SouthCentral Friends of the Pleistocene Meeting, edited by R. D. Mandel and S. C. Caran, Lubbock Lake Landmark Quaternary Research Center Series 4, Lubbock.

1998 Quaternary Paleoenvironmental and Paleoclimate Reconstruction: A Discussion and Critique, with Examples from the Southern High Plains. Plains Anthropologist 43(164):111-124.

Carpenter, S. M., M. Chavez, K. Miller, and K. Lawrence

2006 The McKinney Roughs Site 41BP627: A Stratified Late Archaic II Site on the Colorado River Terraces, Bastrop County, Texas. Prepared for Bastrop Resort Partners, L.P., by SWCA Environmental Consultants, SWCA Cultural Resources Report No. 02-313, Austin.

Carpenter, S. M. and B. A. Houk

2012 Siren Site Chronology: A Reconstruction of the Late Archaic to Late Prehistoric Temporal Sequence of Eastern Central Texas. Bulletin of the Texas Archeological Society 83:99-128.

Carpenter, S. M., K. A. Miller, B. A. Houk, M. J. Galindo, C. Frederick, J. Lowe, K. Hanselka, K. Lawrence, and A. Peyton

2012 The Siren Site (41WM1126), The Long Transition from Archaic to Late Prehistoric Lifeways on the Eastern Edwards Plateau, Williamson County, Texas. Texas Department of Transportation, Environmental Affairs
Division, Archeology Studies Program, Report in progress, Manuscript on file, SWCA Environmental Consultants, Austin.

Clark, J. W., Jr.

1964 The Beaver Head Site (41WM139): A Significant Burned Rock Midden Site in Williamson County, Texas. Manuscript and notes on file at the Texas Archeological Research Laboratory, The University of Texas at Austin.

Collins, M. B.

1994 Chapter 6: Late Archaic Evidence in the Project Area. In Archaic and Late Prehistoric Human Ecology in the Middle Onion Creek Valley, Hays County, Texas-Volume 1, Archeological Components, by R. A. Ricklis and M. B. Collins, pp. 101-189. Studies in Archeology 19, Texas Archeological Research Laboratory, The University of Texas at Austin.

1995 Forty Years of Archeology in Central Texas. Bulletin of the Texas Archeological Society 66:361-400.

2004 Archeology in Central Texas. In The Prehistory of Texas, edited by $\mathrm{T}$. K. Perttula, pp. 101-126. Texas A\&M University Press, College Station.

Collins, M. B. (assembler and editor)

1998 Wilson-Leonard: An 11,000-Year Archeological Record of Hunter-Gatherers in Central Texas. Volumes I-V. Studies in Archeology 31, Texas Archeological Research Laboratory, The University of Texas at Austin and Archeology Studies Program, Report 10, Texas Department of Transportation, Environmental Affairs Division, Austin

Conner, D. R.

1982 Phytolith Analysis of Sediments from Archaeological Sites. In Archaeological Investigations at the San Gabriel Reservoir Districts, Central Texas, Volume 2, edited 
by T. R. Hays, pp. 15-19 through 15-31. Archaeology Program, Institute of Applied Sciences, North Texas State University, Denton.

Coupland, R. T.

1958 The Effects of Fluctuations in Weather upon the Grasslands of the Great Plains. The Botanical Review 24(5):273-317.

Crane, C.

1982 Macrobotanical Analysis. In Archaeological Investigations at the San Gabriel Reservoir Districts, Central Texas, Volume 2, edited by T. R. Hays, pp. 15-5 through 15-12. Archaeology Program, Institute of Applied Sciences, North Texas State University, Denton.

Creel, D. G.

1986 A Study of Prehistoric Burned Rock Middens in West Central Texas. Unpublished Ph.D. dissertation, Department of Anthropology, The University of Arizona, Tucson.

1990 Excavations at 41TG91, Tom Green County, Texas, 1978. Texas State Department of Highways and Public Transportation, Highway Design Division, Publications in Archaeology, Report No. 38, Austin.

1991 Assessing the Relationship between Burned Rock Midden Distribution and Archaic Subsistence in West Central Texas. In Burned Rock Middens of Texas: An Archeological Symposium, edited by T. R. Hester, pp. 33-43. Studies in Archeology 13. Texas Archeological Research Laboratory, The University of Texas at Austin.

1997 Chapter 5: Analysis of the Distribution of Burned Rock Midden Sites in the Study Area. In Burned Rock Middens of Texas: An Archeological Symposium, edited by T. R. Hester, pp. 89-98. Studies in Archeology No. 13. Texas Archeological Research Laboratory, The University of Texas at Austin.
Cummings, L. S.

1994 Chapter 14, Pollen, Phytolith, Macrofloral, and Charcoal Analyses at the Mustang Branch Site (41HY209) and the Barton Site (41HY202). In Archaic and Late Prehistoric Human Ecology in the Middle Onion Creek Valley, Hays County, Texas, Volume 2, Topical Studies, by R. A. Ricklis and M. B. Collins, pp. 387-402. Studies in Archeology 19, Texas Archeological Research Laboratory, The University of Texas at Austin.

Dalan, R.

2008 A review of the role of magnetic susceptibility in archaeogeophysical studies in the USA: Recent developments and prospects. Archaeological Prospection 15:131.

Dalan R. and S. Banerjee

1998 Solving archaeological problems using techniques of soil magnetism. Geoarchaeology 13:3-36.

Dering, J. P.

1997 Appendix D: Macrobotanical Remains. In Hot Rock Cooking on the Greater Edwards Plateau: Four Burned Rock Midden Sites in West Central Texas. Volume II, by S. L. Black, L. W. Ellis, D. G. Creel, and G. T. Goode, pp. 571-600. Texas Archeological Research Laboratory, The University of Texas at Austin, Studies in Archeology 22, and Texas Department of Transportation, Environmental Affairs Department, Archeology Studies Program, Report 2.

1998 Chapter 40: Carbonized Plant Remains. In Wilson-Leonard An 11,000-year Archeological Record of Hunter-Gatherers in Central Texas, assembled by M. B. Collins, pp. 1609-1636, Volume V. Studies in Archeology 31, Texas Archeological Research Laboratory, The University of Texas at Austin and Archeology Studies Program, Report 10, Texas Department of Transportation, Environmental Affairs Division, Austin. 
2000 Appendix II, Macrobotanical Remains from Soil Flotation Samples from the Bessie Kruze Site, with Thoughts about the Blackland Prairie. In Life and Death at the Bessie Kruze Site (41WM13) on the Blackland Prairie of Williamson County, Texas, by L. Johnson, pp. 213-220. Texas Department of Transportation, Environmental Affairs Division, Archeological Studies Program, Report 22.

2002 Appendix F: Plant Remains from the Armstrong Site, 41CV54. In Data Recovery at the Armstrong Site (41CV54), Caldwell County, Texas, Volume I: Background, Methods, and Site Contexts, by E. A. Schroeder and E. R. Oksanen, pp. 265-275. PPA Cultural Resources Report Number 0284, Prepared for GuadalupeBlanco River Authority, by Paul Price Associates, Inc., Austin.

2003a Appendix C: Plant Remains from Rice's Crossing (41WM815). In Archeological Investigations at 41WM815, A Blackland Prairie Site, Williamson County, Texas, by R. K. Brownlow, pp. 113-120. Studies in Archeology 36, Texas Archeological Research Laboratory, The University of Texas at Austin and Archeological Studies Program, Report 23, Environmental Affairs Division, Texas Department of Transportation, Austin.

2003b Appendix E: Macrobotanical Analysis. In Data Recovery Excavations at 41MM340: A Late Archaic Site along Little River in Milam County, Texas, by R. B. Mahoney, S. A. Tomka, R. P. Mauldin, H. J. Shafer, L. C. Nordt, R. D. Greaves, and R. R. Galdeano, pp. 223-233. Texas Department of Transportation, Environmental Affairs Division, Archeological Studies Program Report No. 54 and Center for Archaeological Research, The University of Texas at San Antonio, Archaeological Survey Report, No. 340.

2006 Plant Remains. In Prehistoric Encampments at the Shepherd Site: Testing and Data
Recovery at 41WM1010, Williamson County, Texas, by B. Dixon and R. Rogers, pp. 153-170. Prepared for Texas Department of Transportation, by PBS\&J, Austin.

2011 Appendix A: Plant Remains form 41TV410 and 41TV540. In Results of Archeological Significance Testing at $41 T V 410$ and 41TV540 and Associated Geomorphological Investigations on a Segment of Onion Creek in Travis County, Texas, by A. Figueroa, R. Mauldin, C. Frederick, S. A. Tomka, and J. L. Thompson, pp. 159-164. Center for Archaeological Research, The University of Texas at San Antonio, Archaeological Report No. 420 and Texas Department of Transportation, Environmental Affairs Division, Archeological Studies Program, Report No. 134, Austin.

Dibble, D. S. and D. Lorrain

1967 Bonfire Shelter: A Stratified Bison Kill Site, Val Verde County, Texas. Miscellaneous Papers, No. 1, Texas Memorial Museum, Austin.

Dixon, B. and R. Rogers

2006 Prehistoric Encampments at the Shepherd Site: Testing and Data Recovery at 41WM1010, Williamson County, Texas. Prepared for Texas Department of Transportation, by PBS\&J, Austin.

Eddy, F. W.

1973 Salvage Archeology in the Laneport Reservoir District, Central Texas. Report submitted to the National Park Service by the Texas Archeological Survey, The University of Texas at Austin.

Edwards, J. E.

1974 Geomorphology and Hydrogeology of the Taylor Alluvial Fan, Williamson County, Texas. Unpublished Master's thesis, The University of Texas at Austin.

Ensor, H. B. and C. S. Mueller-Wille

1988 Excavations at the Bull Pen Site, 41BP280, Colorado River Drainage, Bastrop County, 
Texas. Contract Reports in Archaeology, No. 3. Texas Department of Transportation, Austin.

Fenneman, N. M.

1938 Physiography of Eastern United States. McGraw-Hill, New York.

Figueroa, A., R. Mauldin, C. Frederick, S. A. Tomka, and J. L. Thompson

2011 Results of Archeological Significance Testing at 41TV410 and 41 TV540 and Associated Geomorphological Investigations on a Segment of Onion Creek in Travis County, Texas. Center for Archaeological Research, The University of Texas at San Antonio, Archaeological Report No. 420 and Texas Department of Transportation, Environmental Affairs Division, Archeological Studies Program, Report No. 134, Austin.

Frederick, C. D.

2011 Chapter 8: Late Quaternary Alluvial Stratigraphy of the Lower Onion Creek Valley. In Results of Archeological Significance Testing at 41 TV410 and $41 T V 540$ and Associated Geomorphological Investigations on a Segment of Onion Creek in Travis County, Texas, by A. Figueroa, R. Mauldin, C. Frederick, S. A. Tomka, and J. L. Thompson, pp. 69-95. Center for Archaeological Research, The University of Texas at San Antonio, Archaeological Report No. 420 and Texas Department of Transportation, Environmental Affairs Division, Archeological Studies Program, Report No. 134, Austin.

2012 Site Formation Processes. In The Siren Site (41WM1126) and the Long Transition from Archaic to Late Prehistoric Lifeways on the Eastern Edwards Plateau, Williamson County, Texas, by S. Carpenter, K. A. Miller, B. Houk, M. J. Galindo, C. Frederick, J. Lowe, K. Lawrence, K. Hanselka, and A. Peyton, pp. 6-1 through 6-37. Texas Department of Transportation, Environmental Affairs Division,
Archeology Studies Program, Report in progress, Manuscript on file, SWCA, Austin.

Fredlund, G.

1998 Phytolith Analysis. In Wilson-Leonard An 11,000-year Archeological Record of Hunter-Gatherers in Central Texas, Volume V: Special Studies, assembled and edited by M. B. Collins, pp. 1637-1651. Studies in Archeology 31, Texas Archeological Research Laboratory, The University of Texas at Austin, and Archeology Studies Program, Report 10, Texas Department of Transportation, Environmental Affairs Division, Austin.

Fullington R. and K. Fullington

1982 Invertebrate Faunal Analysis. In Archaeological Investigations at the San Gabriel Reservoir Districts, Central Texas, Volume 2, edited by T. R. Hays, pp. 15-33 through 15-56. Archaeology Program, Institute of Applied Sciences, North Texas State University, Denton.

Gadus, E. F, R. C. Fields, and K. W. Kibler

2006 Data Recovery Excavations at the J. B. White Site (41MM341), Milam County, Texas. Reports of Investigations, Number 145, Prewitt and Associates, Inc., Cultural Resources Services, Austin and Archeological Studies Program, Report No. 87, Texas Department of Transportation, Environmental Affairs Division, Austin.

Gardner, K. M.

2006 Appendix A: Analysis of Mussel Shells from 41MM341. In Data Recovery Excavations at the $J$. B. White Site (41MM341), Milam County, Texas, by E. F. Gadus, R. C. Fields, and K. W. Kibler, pp. 195-206. Reports of Investigations, Number 145, Prewitt and Associates, Inc., Cultural Resources Services, Austin and Archeological Studies Program, Report No. 87, Texas Department of Transportation, Environmental Affairs Division, Austin. 
Gould, F. W.

1975 Texas Plants: A Checklist and Ecological Summary. The Texas A\&M University System, Texas Agricultural Experimental Station, College Station.

Griffith, T. B. and K. W. Kibler

2005 Test Excavations at 41BL1214, Bell County, Texas: State Highway 95 Bridge Replacement at the Little River. Technical Reports, Number 74, Texas Department of Transportation, Archeological Studies Program, Report 76.

Hageman, J. B.

1994 Cultural Resources Survey of Portions of the Sandow Mine, Milam County, Texas. Report prepared for Aluminum Company of America, by Espy Huston Associates, Austin.

Hall, G. D.

1981 Allens Creek: A Study in the Cultural Prehistory of the Lower Brazos River Valley, Texas. Research Report No. 61, Texas Archeological Survey, The University of Texas at Austin.

2002 Archaeology at the Crestmont Site. General Investigations Report No. 1, Archaeology Laboratory, Texas Tech University, Lubbock.

Hall, S. A.

1982a Geology of the San Gabriel River Valley. In Archeological Investigations at the San Gabriel Reservoir District, Central Texas, edited by T. R. Hays, pp. 3-19 through 323. Archaeology Program, Institute of Applied Sciences, North Texas State University, Denton.

1982b Pollen Studies at Granger Lake. In Archaeological Investigations at the San Gabriel Reservoir Districts, Central Texas, Volume 2, edited by T. R. Hays, pp. 15-17 through 15-18. Archaeology Program, Institute of Applied Sciences, North Texas State University, Denton.
1990 Channel trenching and climate change in the Southern U.S. Great Plains. Geology 18:342-345.

Hays, T. R. (compiler and editor)

1982 Archaeological Investigations at the San Gabriel Reservoir Districts, Central Texas. Vols. I-IV. Archaeology Program, Institute of Applied Sciences, North Texas State University, Denton.

Hill, R. T.

1901 Geography and Geology of the Black and Grand Prairies, Texas with detailed descriptions of the Cretaceous Formations and special reference to Artesian Waters. Twenty-first Annual Report of the United States Geological Survey, Part VII-Texas. Government Printing Office, Washington DC.

Holloway, R. G., L. M. Raab, and R. Stuckenrath

1987 Pollen Analysis of Late-Holocene Sediments from a Central Texas Bog. The Texas Journal of Science 39(1):71-79.

Houk, B. A., C. Frederick, L. I. Acuna, K. Kersey, and K. A. Miller

2006 Interim Report: Data Recovery at the Siren Site, 41WM1126, Williamson County, Texas. SWCA, Inc., Austin.

Howells, R.

2003 Freshwater Mussel Shell Remains Associated with the Rice's Crossing Site (41WM815). In Archeological Investigations at 41WM815, A Blackland Prairie Site, Williamson County, Texas by R. K. Brownlow, pp. 139-149. Studies in Archeology 36, Texas Archeological Research Laboratory, The University of Texas at Austin and Archeological Studies Program, Report 23, Environmental Affairs Division, Texas Department of Transportation, Austin.

Howells, R. G., R. W. Neck, and H. D. Murray

1996 Freshwater Mussels of Texas. Texas Parks and Wildlife Department Press, Austin. 
Howells, R. G., J. Neel-Hartman, and S. A. Wagner 2003 Appendix G: Freshwater Mussel Shell from 41MM340. In Data Recovery Excavations at 41MM340: A Late Archaic Site along Little River in Milam County, Texas, by R. B. Mahoney, S. A. Tomka, R. P. Mauldin, H. J. Shafer, L. C. Nordt, R. D. Greaves, and R. R. Galdeano, pp. 245-270. Texas Department of Transportation, Environmental Affairs Division, Archeological Studies Program, Report No. 54 and Center for Archaeological Research, The University of Texas at San Antonio, Archaeological Survey Report, No. 340.

Jackson, M. A.

1998 The Nature of Fire-cracked Rock: New Insights from Ethnoarchaeological and Laboratory Experiments. Unpublished Master's thesis, Texas A\&M University, College Station.

Johnson, L.

1962 The Yarbrough and Miller Sites of Northeastern Texas, With Preliminary Definition of the La Harpe Aspect. Bulletin of the Texas Archeological Society 32:141284.

1995 Past Cultures and Climates at the Jonas Terrace Site, 41ME29 of Medina County, Texas. Office of the State Archeologist Report 40. Texas Department of Transportation and Texas Historical Commission, Austin.

2000 Life and Death as Seen at the Bessie Kruze Site (41WM13) on the Blackland Prairie of Williamson County, Texas. Texas Department of Transportation, Environmental Affairs Division, Archeological Studies Program, Report 22.

Johnson, L. and G. T. Goode

1994 A New Try at Dating and Characterizing Holocene Climates, as Well as Archeological Periods, on the Eastern Edwards Plateau. Bulletin of the Texas Archeological Society 65:1-51.
1995 Cultures and Climates at the Jonas Terrace Site, 41ME29 of Medina County, Texas. Office of the State Archeologist Report 40. Texas Department of Transportation and Texas Historical Commission, Austin.

Karbula, J. W., R. Feit, and T. B. Griffith

2001 Changing Perspectives on the Toyah: Data Recovery Investigations of 41TV441, The Toyah Bluff Site, Travis County, Texas. Archeology Series No. 94. Hicks \& Company, Austin.

Karbula, J. W., J. A. Campbell, and B. A. Jones

2011 The Berdoll Site: An Early Archaic Camp on Onion Creek, Travis County, Texas. Bulletin of the Texas Archeological Society 82:135-173.

Keetley, A., L. R. Voellinger, K. Campbell, D. Carghill, W. A. Gose, B. S. Shaffer, J. P. Dering, and R. L. Gearhart

1999 Archeological Investigations at Blockhouse Creek Williamson County, Texas. Prepared for Milburn Homes by Parsons Brinckerhoff Job No. 22233. Parsons Brinckerhoff Quade and Douglas, Inc., Austin.

Kenmotsu, R.

1982 Environmental Setting. In Archeological Investigations at the San Gabriel Reservoir Districts, Central Texas, compiled and edited by T. R. Hays, pp. 3-1 to 3-23. Volume 1, Institute of Applied Sciences, North Texas State University, Denton.

Kibler, K. W

2000 Appendix I, The Bessie Kruze Site and Environs: Landforms, Alluvium, and Cherts. In Life and Death as Seen at the Bessie Kruze Site (41WM13) on the Blackland Prairie of Williamson County, Texas, by L. Johnson, pp. 207-212. Texas Department of Transportation, Environmental Affairs Division, Archeological Studies Program, Report 22.

Kibler, K. W. and A. M. Scott

2000 Archaic Hunters and Gatherers of the 
Balcones Canyonlands: Data Recovery at the Cibolo Crossing Site (41BX377), Bexar County, Texas. Reports of Investigations, Number 126, Prewitt and Associates, Inc., Austin.

Larson, D. A., V. M. Bryant, and T. S. Patty

1972 Pollen Analysis of a Central Texas Bog. The American Midland Naturalist 88(2):358-367.

LaVarera, L. and J. E. Keller

1989 Cultural Resource Investigations within the Sandow Mine Permit Renewal Area, Milam and Lee Counties, Texas. Prepared for the Office of Surface Mining, by North American Consultant, Dallas.

Lohse, J. C.

2013 Chapter 5, Radiocarbon Dates and Dating. In Data Recovery and Analysis at the Texas State University Ticket Kiosk Project, Location at 41HY160, Spring Lake, Hays County, Texas, by J. C. Lohse, A. E. Reid, D. M. Yelacic, and C. L. Timperley, pp. 4352. Archaeological Studies Report No. 32, Center for Archaeological Studies, Texas State University at San Marcos.

Lohse, J. C., A. E. Reid, D. M. Yelacic, and C. L. Timperley

2013 Data Recovery and Analysis at the Texas State University Ticket Kiosk Project, Location at 41HY160, Spring Lake, Hays County, Texas. Archaeological Studies Report No. 32, Center for Archaeological Studies, Texas State University at San Marcos.

Loomis, L. E., W. J. Gabriel, and B. R. Brasher 1992 Genesis of the Quihi Soil in the Uvalde Gravel of South-central Texas. In Late Cenozoic Alluvial Stratigraphy and Prehistory of the Inner Gulf Coastal Plain, South-Central Texas. Guidebook to the $10^{\text {th }}$ Annual South-Central Friends of the Pleistocene Meeting, edited by R. D. Mandel and S. C. Caran, Lubbock Lake Landmark Quaternary Research Center Series 4, Lubbock.
Loy, T. H.

1994 Residue Analysis of Artifacts and Burned Rock from the Mustang Branch and Barton Sites (41HY209 and 41HY202). In Archaic and Late Prehistoric Human Ecology in the Middle Onion Creek Valley, Hays County, Texas, by R. A. Ricklis, and M. B. Collins, pp. 607-627. Studies in Archeology 19, Texas Archeological Research Laboratory, The University of Texas at Austin.

Lukowski, P. D.

1988 Archaeological Investigations at 41BXI,

Bexar County, Texas. Center for Archaeological Research, The University of Texas at San Antonio, Archaeological Survey Report, No. 135.

Mahoney, R. B. and S. A. Tomka

2000 National Register of Eligibility Testing of 41MM340 and 41MM341 along Little River, Milam County, Texas. Center for Archaeological Research, The University of Texas at San Antonio, Archaeological Survey Report, No. 340. Draft.

Mahoney, R. B., S. A. Tomka, and R. P. Mauldin

2003 Chapter 3: Archeological Background and Cultural Setting. In Data Recovery Excavations at 41MM340: A Late Archaic Site along Little River in Milam County, Texas, by R. B. Mahoney, S. A. Tomka, R. P. Mauldin, H. J. Shafer, L. C. Nordt, R. D. Greaves, and R. R. Galdeano, pp. 19-23. Texas Department of Transportation, Environmental Affairs Division, Archeological Studies Program Report No. 54 and Center for Archaeological Research, The University of Texas at San Antonio, Archaeological Survey Report, No. 340 .

Mahoney, R. B., S. A. Tomka, R. P. Mauldin, H. J. Shafer, L. C. Nordt, R. D. Greaves, and R. R. Galdeano

2003 Data Recovery Excavations at 41MM340, A Late Archaic Site along Little River in Milam County, Texas. Environmental Affairs Division, Texas Department of Transportation, Archeology Studies 
Program, Report No. 54, and Center for Archaeological Research, The University of Texas at San Antonio, Report No. 340.

Malof, A. F. and M. S. Taylor

2011 A Terminal Archaic Burial from the Central Colorado River Basin, Travis County, Texas. Bulletin of the Texas Archeological Society 82:251-280.

Marie, R.

2006 Invertebrate Faunal Analysis. In Prehistoric Encampments at the Shepherd Site: Testing and Data Recovery at 41WM1010, Williamson County, Texas, by B. Dixon and R. Rogers, pp. 159-170. Prepared for Texas Department of Transportation, by PBS\&J, Austin.

Mauldin, R.

2003 Appendix I: ${ }^{18} \mathrm{O}$ and ${ }^{13} \mathrm{C}$ Isotopes. In Data Recovery Excavations at 41MM340, A Late Archaic Site along Little River in Milam County, Texas, by R. B. Mahoney, S. A. Tomka, R. P. Mauldin, H. J. Shafer, L. C. Nordt, R. D. Greaves, and R. R. Galdeano, pp. 275-277. Environmental Affairs Division, Texas Department of Transportation, Archeology Studies Program, Report No. 54, and Center for Archaeological Research, The University of Texas at San Antonio, Report No. 340.

2006 Appendix D: Stable Carbon and Oxygen Isotopic Variability in Snail Shells from 41MM340 and 41MM341. In Data Recovery Excavations at the J. B. White Site (41MM341), Milam County, Texas, by E. F. Gadus, R. C. Fields, and K. W. Kibler, pp. 227-235. Reports of Investigations, Number 145, Prewitt and Associates, Inc., Cultural Resources Services, Austin and Archeological Studies Program, Report No. 87, Texas Department of Transportation, Environmental Affairs Division, Austin.

2011 Chapter 11: Summary. In Results of Archeological Significance Testing at 41TV410 and 41TV540 and Associated
Geomorphological Investigations on a Segment of Onion Creek in Travis County, Texas, by A. Figueroa, R. Mauldin, C. Frederick, S. A. Tomka, and J. L. Thompson, pp. 137-139. Archaeological Report No. 420, Center for Archaeological Research, The University of Texas at San Antonio and Texas Department of Transportation, Environmental Affairs Division, Archeological Studies Program, Report No. 134, Austin.

Mauldin, R. P. and D. L. Nickels

2003 Chapter 11: Burned Rock Middens in Texas. In Archaeological Testing to Determine the National Register Eligibility Status of Eighteen Prehistoric Sites on Camp Bowie, Brown County, Texas, by R. P. Mauldin, D. L. Nickels and C. J. Broehm, pp. 217-231. Volume 1. Center for Archaeological Research, The University of Texas at San Antonio, Archaeological Survey Report, No. 334.

Mauldin, R., S. Tomka, and A. Figueroa

2011 Chapter 9: Attempts at Reconstruction of Paleoenvironmental Conditions and Resource Structure on the Onion Creek Floodplain. In Results of Archeological Significance Testing at $41 T V 410$ and $41 T V 540$ and Associated Geomorphological Investigations on a Segment of Onion Creek in Travis County, Texas, by A. Figueroa, R. Mauldin, C. Frederick, S. A. Tomka, and J. L. Thompson, pp. 97-108. Center for Archaeological Research, The University of Texas at San Antonio, Archaeological Report No. 420 and Texas Department of Transportation, Environmental Affairs Division, Archeological Studies Program, Report No. 134, Austin.

Mauldin, R., J. Thompson, and L. Kemp

2012 Reconstructing the Role of Bison in the Terminal Late Prehistoric (Toyah) Period in Texas. In The Toyah Phase of Central Texas: Late Prehistoric Economic and Social Processes, edited by N. A. Kenmotsu and D. K. Boyd, pp. 90-110. 
Texas A\&M University Press, College Station.

McClure, W. L.

2003 The Vertebrates of the Rice's Crossing Site (41WB815). In Archeological Investigations at 41WM815, A Blackland Prairie Site, Williamson County, Texas by R. K. Brownlow, pp. 99-111. Studies in Archeology 36, Texas Archeological Research Laboratory, The University of Texas at Austin and Archeological Studies Program, Report 23, Environmental Affairs Division, Texas Department of Transportation.

McDonald, J.

1982 Appendix II: Nonhuman Bones from the Loeve-Fox site: A Preliminary Analysis. In Archeological Investigations at the LoeveFox Site, Williamson County, Texas, by E. R. Prewitt, pp. 117-120. Reprints in Archeology Number 1, Prewitt and Associates, Inc., Austin.

McGinley, A. N.

1978 Elemental Analysis of Edwards Formation Chert: A Comparison of Sample Areas. Unpublished Master's thesis, Texas A\&M University, College Station.

McParland, P.

1977 Experiments in the Firing and Breaking of Rocks. Calgary Archaeologist 5:31-33.

Mear, C. E.

1998 Terrace Deposits and Late Quaternary Climate, South-Central Edwards Plateau, Texas. Bulletin of the Texas Archeological Society 69:79-88.

Mehalchick, G., D. K. Boyd, K. W. Kibler, and C. H. Ringstaff

2004 Shifting Sands and Geophytes: Geoarcheological Investigations at Paluxy Sites on Fort Hood, Texas. United States Army Fort Hood, Archeological Resource Management Series, Research Report No. 48.
Meissner, B. A.

2011 Appendix N: Faunal Material form 41TV540. In Results of Archeological Significance Testing at $41 T V 410$ and $41 T V 540$ and Associated Geomorphological Investigations on a Segment of Onion Creek in Travis County, Texas, by A. Figueroa, R. Mauldin, C. Frederick, S. A. Tomka, and J. L. Thompson, pp. 357-362. Center for Archaeological Research, The University of Texas at San Antonio, Archaeological Report No. 420 and Texas Department of Transportation, Environmental Affairs Division, Archeological Studies Program, Report No. 134, Austin.

Meissner, B. A. and R. B. Mahoney

2003 Appendix B: Vertebrate Remains. In Data Recovery Excavations at 41MM340: A Late Archaic Site along Little River in Milam County, Texas, by R. B. Mahoney, S. A. Tomka, R. P. Mauldin, H. J. Shafer, L. C. Nordt, R. D. Greaves and R. R. Galdeano, pp. 197-206. Environmental Affairs Division, Texas Department of Transportation, Archeological Studies Program, Report No. 54 and Center for Archaeological Research, The University of Texas at San Antonio, Archaeological Survey Report No. 340.

Montgomery, J. A.

1982 The geomorphic evolution of the Taylor Black Prairie between the Trinity and Colorado Rivers, central Texas. Unpublished Master's thesis, Baylor University, Waco.

1983 The geomorphic Evolution of the Taylor Black Prairie between the Trinity and Colorado Rivers (Abstract). American Association of Petroleum Geologists Bulletin 67:517-518.

Moore, G. L.

1978 Archeological Test Excavations at 41WM21 in Granger Reservoir, Williamson County, Texas. Report Submitted to the U.S. Army Corps of 
Engineers, Fort Worth District by Texas A\&M Research Foundation Project No. 3446, Report No. 37 (revised), Texas A\&M University.

Nash, M.

2006 Vertebrate Faunal Analysis. In Prehistoric Encampments at the Shepherd Site: Testing and Data Recovery at 41WM1010, Williamson County, Texas, by B. Dixon and R. Rogers, pp. 156-158. Prepared for Texas Department of Transportation, by PBS\&J, Austin.

National Parks Service

1995 How to Apply the National Register Criteria for Evaluation. National Register Bulletin 15. United States Department of Interior, National Parks Service, National Register Division, Washington, D.C.

National Cooperative Soil Survey

2012 Official Description of the Frio Series. https://soilseries.sc.egov.usda.gov/OSD D ocs/F/FRIO.html, accessed July 2012.

Natural Resource Conservation Service

2012 http://websoilsurvey.nrcs.usda.gov/app/, accessed July 2012.

Nickels, D. L., C. B. Bousman, J. D. Leach, and D. A. Cargill

2001 Test Excavations at the Culebra Creek Site, 41BX126, Bexar County, Texas. Archaeological Survey Report No. 265, Center for Archaeological Research, The University of Texas at San Antonio and Archeology Studies Program, Report No. 3, Environmental Affairs Division, Texas Department of Transportation, Austin.

Nordt, Lee C.

1992 Archaeological Geology of the Fort Hood Military Reservation, Fort Hood, Texas. United States Army Fort Hood, Archeological Resource Management Series, Research Report Number 25.

1993 Additional Geoarchaeological Investigations at the Fort Hood Military
Reservation, Fort Hood, Texas. United States Army Fort Hood, Archeological Resource Management Series, Research Report Number 28, Addendum to Research Report Number 25.

2003 Geomorphology. In Data Recovery Excavations at 41MM340, A Late Archaic Site along Little River in Milam County, Texas, by R. B. Mahoney, S. A. Tomka, R. P. Mauldin, H. J. Shafer, L. C. Nordt, R. D. Greaves, and R. R. Galdeano, pp. 75-86. Environmental Affairs Division, Texas Department of Transportation, Archeology Studies Program, Report No. 54, and Center for Archaeological Research, The University of Texas at San Antonio, Report No. 340.

Nordt, L. C., J. von Fisher, and L. Tieszen

2007 Late Quaternary temperature record from buried soils of the North American Great Plains. Geological Society of America 35(2):159-162.

Nordt, L. C., T. W. Boutton, C. T. Hallmark, and M. R. Waters

1994 Late Quaternary vegetation and climate change in Central Texas based on the isotopic composition of organic carbon. Quaternary Research 41:109-120.

Parish, R.

2009 A chert sourcing study using visible/nearinfrared reflectance spectroscopy at the Dover Quarry sites, Tennessee. Murray State University, Department of Geosciences. Accessed online at http://core.tdar.org/document/374237.

Patterson P. and H. J. Shafer

1980 Archeological Surveys of Granger and North Fork Reservoirs, Volumes I and II. Reports submitted to the National Parks Service by Texas A\&M Research Foundation, Report No. 38b, Anthropology Research Laboratory, Texas A\&M University. 
Peter, D. E., D. Prikryl, O. F. McCormick, and M. Demuynck

1982 Site Excavation Reports: Primary Contract. In Archeological Investigations at the San Gabriel Reservoir Districts, Central Texas. Volume 1, compiled and edited by T. R. Hays, pp. 8-1 through 8-297. Archaeology Program, Institute of Applied Sciences, North Texas State University, Denton.

Perry, L. and J. M. Quigg

2011 Starch Remains and Stone Boiling in the Texas Panhandle, Part I: The Pipeline, Corral, and Pavilion Sites. Plains Anthropologist 56(218):95-107.

Perry, L., D. Sandweiss, D. R. Piperno, K. Rademaker, M. Malpass, A. Umire, and P. de la Vera

2006 Early Maize Agriculture and Interzonal Interaction in Southern Peru. Nature 440(2):76-78.

Peter, D. E., T. R. Hays, and M. A. Demuynck 1982a The Archaeology of the San Gabriel Reservoir Districts. In Archaeological Investigations at the San Gabriel Reservoir Districts, Central Texas, Volume 2, edited by T. R. Hays, pp. 16-1 through 17-30. Archaeology Program, Institute of Applied Sciences, North Texas State University, Denton.

Peter, D. E., D. Prikryl, O. F. McCormick, and M. A. Demuynck

1982b Site Excavation Reports: Primary Contract. In Archaeological Investigations at the San Gabriel Reservoir Districts, Central Texas, Volume 1, edited by T. R. Hays, pp. 8-11 through 8-297. Archaeology Program, Institute of Applied Sciences, North Texas State University, Denton.

Piperno D. R. and I. Holst

1998 The Presence of Starch Grains on Prehistoric Stone Tools from the Humid Neotropics: Indications of Early Tuber Use and Agricultural in Panama. Journal of Archeological Science 25:765-776.

Piperno, D. R., A. J. Ranere, I. Holst, and P. Hansell
2000 Starch Grains Reveal Early Root Crop Horticulture in the Panamanian Tropical Forest. Nature 407:894-897.

Prewitt, E.

1974 Archeological Investigations at the LoeveFox Site, Williamson County, Texas. Research Report 49. Texas Archeological Survey, The University of Texas at Austin.

1976 Late Archaic Occupations at the LoeveFox Site: The San Marcos and Twin Sisters Phases. In The Texas Archaic: A Symposium, T. R. Hester editor, pp. 67-77. Center for Archaeological Research Special Report 2, The University of Texas at Austin.

1981 Cultural Chronology in Central Texas. Bulletin of the Texas Archeological Society 52:65-89.

1982a Archeological Investigations at the LoeveFox and Loeve Tombstone Bluff Sites in the Granger Lake District of Central Texas. In Archaeological Investigations at the San Gabriel Reservoir Districts, Central Texas, edited by T. R. Hays, Volume 4. Institute of Applied Sciences, North Texas State University, Denton.

1982b Archeological Investigations at the LoeveFox Site, Williamson County, Texas. Reprints in Archeology Number 1, Prewitt and Associates, Inc., Austin, Texas.

1985 From Circleville to Toyah: Comments on Central Texas Chronology. Bulletin of the Texas Archeological Society 54:201-238.

1995 Distribution of Typed Projectile Points in Texas. Bulletin of the Texas Archeological Society 66:83-173.

2012 Toyah: Reflections on Evolving Perceptions. In The Toyah Phase of Central Texas: Late Prehistoric Economic and Social Processes, edited by N. A. Kenmotsu and D. K. Boyd, pp. 181-203. Texas A\&M University Press, College Station. 
Quigg, J. M.

1996 Chapter 11, Overall Summary and Interpretations. In Archeological Testing at Fort Hood: 1994-1995, Volume II, edited by W. Nicholas Trierweiler, pp. 653-705. United States Army Fort Hood, Archeological Resource Management Series, Research Report No. 35.

2011 Use-Wear and Starch Residue Analyses on an In Situ Corner-Tang Knife from the Texas Panhandle: Towards and Understanding of Function. Plains Anthropologist 56(217):37-44.

Quigg, J. M., C. D. Frederick, P. M. Matchen, and K. DuBois

2010 Landis Property: Data Recovery at Three Prehistoric Sites (41PT185, 41PT186, and 41PT245) in Potter County, Texas. TRC Technical Report No. 150832. Manuscript on file, TRC, Austin and Bureau of Land Management, Santa Fe.

Quigg, J. M., P. M. Matchen, C. D. Frederick and R. A. Ricklis

2011a Root-Be-Gone (41YN452): Data Recovery of Late Archaic Components in Young County, Texas. Texas Department of Transportation, Environmental Affairs Division, Archeological Studies Program Report 135 and TRC Environmental Corporation, Technical Report Nos. 50907 and 171219, Austin.

Quigg, J. M., R. A. Ricklis, P. M. Matchen, and J. T. Abbott

2013a Data Recovery at 41MI96 In Mills County, Texas. Texas Department of Transportation, Environmental Affairs Division, Archeological Studies Program Report 150 and TRC Environmental Corporation, Technical Report No. 192832, Austin.

Quigg, J. M., C. Lintz, G. Smith, D. DeMar and J. D. Owens

2011b Cultural Resource Investigations to Offset Mechanical Impacts to the Clear Creek Golf Course Site (41CV413), Fort Hood, Texas. United States Army Fort Hood,
Archeological Resource Management Series, Resource Report No. 60.

Quigg, J. M., P. M. Matchen, C. D. Frederick, B. Gregory, and R. A. Ricklis

2012 Assessment of the Barrett Site (41MM382): Milam County (CSJ: 0590-05-027), Texas. Prepared for Texas Department of Transportation, Environmental Affairs Division, Austin, by TRC Environmental Corporation, Austin.

Quigg, J. M., P. M. Matchen, C. D. Frederick, R. A. Ricklis, B. Gregory, D. Maki and M. Bateman

2013b Long View (41RB112): Data Recovery of Two Plains Village Components in Roberts County, Texas, Volumes I and II. Texas Department of Transportation, Environmental Affairs Division, Archeological Studies Program Report 147 and TRC Environmental Corporation, Technical Report Nos. 50907 and 171219, Austin.

Ramsey, R. N.

2004 Soil Survey of Milam County, Texas. United States Department of Agriculture, Natural Resources Conservation Service, in cooperation with the Texas Experimental Station and Texas State Soil and Water Conservation Board.

Ricklis, R. A.

2011 New Perspectives on the Archaic of the Texas Coastal Plain: The Buckeye Knoll Site (41VT98) on the Lower Guadalupe River near Victoria, Texas. Bulletin of the Texas Archeological Society 82:31-76.

2012 Cultural and Ecological Change. In Archaeology and Bioarchaeology of the Buckeye Knoll Site, 4IVT98, Victoria County, Texas, edited by R. A. Ricklis, R. A. Weinstein and D. C. Wells, pp. 679-700. Coastal Environments, Inc., Corpus Christi.

Ricklis, R. A. and M. B. Collins

1994 Archaic and Late Prehistoric Human Ecology in the Middle Onion Creek Valley, Hays County, Texas-Volume 1, 
Archeological Components. Studies in Archeology, No. 19, Texas Archeological Research Laboratory, The University of Texas at Austin.

Ricklis, R. A. and M. D. Blum

1997 The Geoarchaeological Record of Holocene Sea Level Change and Human Occupation of the Texas Gulf Coast. Geoarchaeology: An International Journal 12(4):287-314.

Schambach, F. F.

1998 Pre-Caddoan Cultures of the TransMississippi South. Research Series No. 53, Arkansas Archaeological Survey, Fayetteville.

Schoeneberger, P. J., D. A. Wysocki, E. C. Benham, and W. D. Broderson (editors)

2002 Field Book for Describing and Sampling Soils. Version 2.0. Natural Resources Conservation Service, National Soil Survey Center, Lincoln.

Schroeder, E.

2000 Archeological Investigations along the Williamson Drive Wastewater Interceptor and Data Recovery at the Dobb's Hollow Canyon site (41WM40): A Prehistoric Site, City of Georgetown Williamson County, Texas. Prepared for the City of Georgetown by Paul Price Associates, Inc., Austin.

Schroeder, E. A. and E. R. Oksanen

2002 Data Recovery at the Armstrong Site (41CW54), Caldwell County, Texas. Prepared for Guadalupe-Blanco River Authority, by Paul Price Associates, Inc., Austin.

Shackley, M. S. (editor)

2012 X-Ray Fluorescence Spectrometry (XRF) in Geoarchaeology. Springer, New York.

Shafer, H. J.

2006 People of the Prairie: A Possible Connection to the Davis Site Caddo. Archeological Program, Environmental Affairs Division, Texas Department of
Transportation and Prewitt and Associates, Inc., Austin.

Shafer, H. J. and J. E. Corbin

1965 An Appraisal of the Archeological Resources of North Fork, South Fork and Laneport Reservoirs, Williamson County, Texas. Report submitted to the National Park Service by the Texas Archeological Salvage Project, The University of Texas at Austin.

Shafer, H. J. and V. M. Bryant

1976 A Preliminary Assessment of the Cultural Resources in the North Fork and Granger Reservoir, Williamson County, Texas. A Supplemental Report to an Archaeological Survey of Granger and North Fork Reservoir, Preliminary Report. Anthropology Research Laboratory. Texas A\&M University, College Station.

Shafer, H. J., P. Dering, and S. P. Baxter

1975 Richland Creek Watershed, Hill County, Texas: Archeological Surveys of Floodwater Retaining Structure Site Nos. 70, 71A, 77A, 84, 85, 91A, 92A, 92B, 97, 130, and 136. Anthropology Research Laboratory. Texas A\&M University, Collage Station.

Sorrow, W. M.

1969 Archeological Investigations at the John Ischy Site: A Burnt Rock Midden in Williamson County, Texas. Papers of the Texas Archeological Salvage Project, No. 18. The University of Texas at Austin.

Story, D. A.

1990 Cultural History of the Native Americans. In The Archeology and Bioarcheology of the Gulf Coastal Plain, by E. A. Story, J. A. Guy, B. A. Burnett, M. D. Freeman, J. Rose, D. G. Steele, B. W. Olive, and K. J. Reinhard, Vol. 1. pp. 163-366. Arkansas Archeological Survey, Research Series 38, Fayetteville.

Suhm, D. A. and E. B. Jelks

1962 Handbook of Texas Archeology: Type 
Descriptions. The Texas Archeological Society, Special Publication Number One and The Texas Memorial Museum Bulletin Number Four.

Tharp, B. C.

1939 The Vegetation of Texas, Texas Academy of Science publications in Natural History, Non-Technical Series 1.

Tomka, S. A. and R. P. Mauldin

2003 Chapter 9: Paleoenvironmental Reconstruction. In Data Recovery Excavations at 41MM340, A Late Archaic Site along Little River in Milam County, Texas, by R. B. Mahoney, S. A. Tomka, R. P. Mauldin, H. J. Shafer, L. C. Nordt, R. D. Greaves, and R. R. Galdeano, pp. 95-108. Environmental Affairs Division, Texas Department of Transportation, Archeology Studies Program, Report No. 54, and Center for Archaeological Research, The University of Texas at San Antonio, Report No. 340.

Tomka, S. A., H. J. Shafer, and R. P. Mauldin 2003 Lithic Technology at 41MM340. In Data Recovery Excavations at 41MM340: A Late Archaic Site along Little River in Milam County, Texas, by R. B. Mahoney, S. A. Tomka, R. P. Mauldin, H. J. Shafer, L. C. Nordt, R. D. Greaves and R. R. Galdeano, pp. 133-154. Environmental Affairs Division, Texas Department of Transportation, Archeological Studies Program, Report No. 54 and Center for Archaeological Research, The University of Texas at San Antonio, Archaeological Survey Report No. 340.

Toomey, R. S., III

1993 Late Pleistocene and Holocene Faunal Changes at Hall's Cave, Kerr County, Texas. Unpublished Ph.D. dissertation, Department of Geology, The University of Texas at Austin.

Toomey, R. S., III, M. D. Blum, and S. Valastro, Jr. 1993 Late Quaternary Climates and
Environments of Edwards Plateau, Texas. Global and Planetary Change 7:299-320.

Turner, E. S., T. R. Hester, and R. McReynolds

2011 Stone Artifacts of Texas Indians. Completely revised Third Edition. Taylor Trade Publishing, London, New York.

Texas Department of Transportation (TxDOT)

2010 TxDOT Lithic Protocol Version 2.1, Chipped Stone Analytical Protocol, TxDOT Archeological Studies Program, On File with Environmental Affairs Division, Texas Department of Transportation, Austin.

\section{TxDOT Archeology Staff}

2008 Integrity Protocol (draft). Assessing Site Integrity for TXDOT Projects Guidelines: Practical Considerations and Lines of Evidence. Environmental Affairs Division, Texas Department of Transportation, Austin.

Waters M. R. and L. C. Nordt

1995 Late Quaternary Floodplain History of the Brazos River in East-Central Texas. Quaternary Research 43:311-319.

Whittaker, J. C. and E. J. Kaldahl

2001 Where the Waste Went: A Knapper's Dump at Grasshopper Pueblo in Lithic Debitage: Context, Form, and Meaning, edited by $\mathrm{W}$. Andrefsky Jr., pp. 32-60. University of Utah, Salt Lake City.

Witter, D. C.

1969 Appendix B, Identification of Faunal Remains. In Archeological Investigations at the John Ischy Site: A Burnt Rock Midden in Williamson County, Texas, by W. M. Sorrow, pp. 61-62. Papers of the Texas Archeological Salvage Project, No. 18. The University of Texas at Austin.

Weir, F. A.

1976 The Central Texas Archaic. Unpublished Ph.D. dissertation, Washington State University, Pullman, Washington. 
Wisseman, S. U., T. E. Emerson, M. R. Hynes and R. E. Hughes

2004 Using a Portable Spectrometer to Source Archaeological Materials and to Detect Restorations in Museum Objects. Journal of the American Institute for Conservation 43:129-138
Yates, B. C.

1982 Vertebrate Faunal Remains. In Archaeological Investigations at the San Gabriel Reservoir Districts, Central Texas, Volume 2, edited by T. R. Hays, pp. 15-57 through 15-227. Archaeology Program, Institute of Applied Sciences, North Texas State University, Denton. 
This page intentionally left blank. 


\subsection{GLOSSARY OF TECHNICAL TERMS}

A Horizon: The near surface horizon of a natural soil. This is a carbon rich soil horizon characterized by an accumulation of partially decomposed to decomposed organic matter and eluvial loss of constituents such as clays and carbonates, which tend to accumulate in the deeper B horizon. The A horizon represents the upper solum of a soil. Lower case letters with the upper case letter A indicate specific characteristics of that A horizon. An Ab designation indicates the A horizon is buried. An Ap designation indicates a disturbed or anthropically modified soil such as in a plow zone.

Accelerated Mass Spectrometry (AMS): Laboratory technique that separates and identifies ions based on their mass to charge ratios. This technique is used in radiocarbon dating tiny particles of carbon in organic remains and residues.

Acidic: Containing acid bearing pollutants.

Acryloid B-72: This is a conservation material used to stabilize or glue artifacts together. It is an ethyl methacrylate copolymer.

A.D.: Anno domini in Latin. "In the year of our Lord." For example, A.D. 1000 is 1,000 years After Christ. This is generally used when a B.P. radiocarbon date is calibrated to the tree ring results with a calibration formula.

Agavaceae: A plant family name that refers to fiber, vascular bundle, or the central stem sections that cannot be specifically identified as agave (Agave), yucca (Yucca) or sotol (Dasylirion).

Allostratigraphic Unit: Depositional unit made up of sediments dating to a similar period of deposition.

Alluvium: Clastic sediments, such as sand, silt, or clay deposited by a flowing stream, either in the channel or outside the channel during overbank flooding.

Archeobotanical: This is the study of remains of plants used by man in ancient times, which have survived in archeological contexts.

Argillins: These are clay coatings on ped- or pore surfaces.

Azelaic Acid: This is a chemical biomarker in lipid residue analysis and a short chain dicarboxylic acid associated with the oxidation of unsaturated fatty acids. Its presence may indicate plant seed processing.

B.C.: The abbreviation for Before Christ, in contrast to After Christ (A.D.).

Biface or Bifacial: A stone tool that has two distinct sides or faces, both of which have been substantially worked and/or flaked. The biface may take the form of many shapes and sizes and used in diverse activities.

B Horizon: The lower solum of a natural soil. A $\mathrm{B}$ horizon is a mineral soil horizon characterized by an accumulation of constituents such as clays, carbonates or salts, or organic complexes that have been translocated from the A horizon. Common subordinates include lowercase letters such as $t$ as $\mathrm{Bt}$, which indicates accumulation of alluvial clays. The lowercase $\mathrm{k}(\mathrm{Bk})$ indicates accumulation of carbonate. The lower case $\mathrm{w}$ indicates structural or color changes with no significant accumulations of alluvial material.

Benthic Diatoms: Those species of diatoms that live in sediment, microbial mats and vegetation at or near the floor of a stream or lake.

Biomarker: This is in lipid residue analysis, a molecular associated with a narrow range of substances, or the presence and distribution of certain types of lipids that enables a residue to be identified with a high degree of precision. 
Biosilicates: This is a general term to include various tiny hard bodies that contain silicon and are developed in plants such as phytoliths, diatoms, algal statospores and sponge spicules.

Bioturbation: The churning and mixing of sediments by living organisms, including burrowing rodents, insects, worms, and plant roots.

Biplot: A biplot is a special type of graph following from principal component analysis on which both the samples and elements are displayed. Examination of a biplot from the principal component analysis of ceramic specimens often leads to identification of the analyzed elements responsible for differentiating groups of specimens from one another.

Bivariate Plot (Scatter Plot): A two-dimensional graph where the $\mathrm{x}$-axis and $\mathrm{y}$-axis symbolize a pair of measured or calculated variables. The points on a bivariate plot represent the position of individual samples and show the concentration of one element compared to another. These graphs are used to recognize possible structure in a data set.

B.P.: An abbreviation for before present, which in radiocarbon dating is referenced to the standard year A.D. 1950, which is considered "present". Generally B.P. dates have not been tree ring corrected using one of the calibration formulas.

$\boldsymbol{\beta}$-sitosterol and Stigmasterol: These are sterols associated with plant products, which can be detected during lipid analysis. Its presence indicates plant residues.

Burned Rock Dump: A loose cluster of previously heated rocks that exhibits no horizontal patterning to the positions of the rocks and lacks indications of in situ heating/burning, such as a prepared basin, lenses of charcoal or ash, and/or the absence of an oxidation rim. Scattered charcoal or other cultural items may be present between or around the burned rocks.
Burned Rock Midden: An accumulation of a large quantity of discarded burned rocks previously employed in multiple cooking activities. These accumulations were the results of long extensive cooking episodes generally in association with rock ovens.

$\mathbf{C}_{3}$ Plants: A photosynthetic pathway that most trees and flowering bushes use to assimilate carbon dioxide into their systems. The average carbon isotope of $\mathrm{C}_{3}$ matter is $-26.5 \%$ with a range from about $-19.0 \%$ to $-34.0 \%$.

$\mathbf{C}_{4}$ Plants: A photosynthetic pathway used by most arid (xeric) grasses and maize (corn) to assimilate carbon dioxide into their systems. The average carbon isotope of $\mathrm{C}_{4}$ matter is $-12.5 \%$ with a range of $-6 \%$ to $-19 \%$. These plants are more resistant to stress due to lack of water, but more susceptible to cold temperatures.

C Horizon: Weathered, but relatively unaltered parent material at the base of a soil profile, generally below the B horizon. This term is roughly synonymous with subsoil, although the latter term is often used to encompass the lower B horizon.

Calcareous: Rocks, minerals, or sediment containing calcium carbonates.

Calcite: A mineral consisting only or mainly of calcium, the principal mineral of limestone and marble.

Calcium: A chemical element with the symbol $\mathrm{Ca}$ and atomic number 20. Calcium is a soft gray alkaline earth metal, and is the fifth most abundant element by mass in the Earth's crust. Calcium is also the fifth most abundant dissolved ion in seawater by both molarity and mass, after sodium, chloride, magnesium, and sulfate.

Caliche: A more or less cemented deposit of calcium carbonate in soils of warm-temperate, subhumid to arid areas. Caliche, normally white, occurs as soft, thin layers in the soil or as hard, thick 
beds just beneath the solum, or it is exposed at the surface by erosion.

CAM Plants: A photosynthetic pathway for assimilating carbon dioxide into plants that can change from $\mathrm{C}_{3}$-like to $\mathrm{C}_{4}$-like pathways depending on the diurnal (day or night) cycle. Most succulent plants such as cactus have crassulacean acid metabolism (CAM) pathways. The carbon isotope values of most CAM plants in Texas such as Agave lechuguilla and Opuntia englmannii are similar to the values in $\mathrm{C}_{4}$ plants (see Eickmeier and Bender 1976).

Campesterol: This and stigmasterol and sitosterol are sterols found in plant tissue, which can be detected during lipid analysis. Its presence indicates that plants were processed.

Canonical Discriminant Analysis (CDA): This procedure finds axes (the number of categories $-1=$ k-1 canonical coordinates) that best separate the categories. These linear functions are uncorrelated and define, in effect, an optimal k-1 space through the $n$-dimensional cloud of data that best separates (the projections in that space of) the k groups.

Carbonates: These are rock or mineral classes that include limestone, calcite, ooids, and bioclasts. White carbonate filaments are often observed in $\mathrm{C}$ horizons of soils.

Chalcedony: A cryptocrystalline variety of quartz or chert. Chalcedony is often a component of other cherts. It may be translucent or semitranslucent, has a wax-like luster, and generally is white, pale blue, gray, blown, or black in color.

Cheno-am: A term used in botanical classification that includes the plant family of Chenopodiaceae (goosefoot) and the genus Amaranthus (pigweed), with tiny charred seeds that are indistinguishable from each other.

Cholesterol: This is the major sterol in animal tissue, which can be detected during lipid analysis. Its presence indicates animal residues.
Chromatograms: This is the representation of mass spectrometry data, where the $\mathrm{x}$-axis represents time and the $y$-axis represents signal intensity. The source data contains mass information. The most common use of this data representation is when mass spectrometry is used in conjunction with some form of chromatography, such as in liquid chromatography-mass spectrometry or gas chromatography-mass spectrometry.

Clast: Any detrital particle of sediment created by the weathering and disintegration of a larger rock mass and transported by water, wind, or ice. Clasts also include discrete particulates created and deposited by volcanic action.

Clay: This is mineral sediment particles less than 0.002 millimeters in diameter. As a soil textural class, soil mineral that is 40 percent or more clay, less than 45 percent sand, and less than 40 percent silt.

Cluster Analysis (CA): A type of numerical classification that uses the value of attributes to cluster data. Clustering is the classification of objects into groups so that objects from the same cluster are more similar to each other than to objects from different clusters. Often similarity is defined according to a distance measure. Clustering is a common technique for statistical data analysis, which is used in many fields, including data mining, pattern recognition, image analysis and bioinformatics.

Collagen: The organic (protein) component of bone. It is this component that is usually radiocarbon dated by most laboratories, and decays over time.

Colluvium: Soil material, rock fragments, or both, moved by creep, slide, or local wash that is deposited at the base of steep slopes.

Complex: A group of archeological sites that date to the same time period and that contain similar artifacts. This term expresses a relationship of 
common cultural or technological traits in assemblages within widespread geographic area.

Component: An archeological site or portion of a site that is spatially and chronologically discrete from other accumulations of artifacts. These can be horizontally or vertically differentiated.

Conifers: Any member of the order Pinales, woody plants that bear their seeds and pollen on separate, cone-shaped structures. They constitute the largest division of gymnosperms, with more than 550 species. Most are evergreen, upright trees and shrubs. They grow throughout North American and prefer temperate climate zones. Conifers include the pines (Pinus), junipers (Juniperus), spruces (Picea), hemlocks (Tsuga), firs (Abies), larches (Larix), yews (Taxus), cypresses (Cupressus), bald cypresses (Taxodium), Douglas firs (Pseudotsuga), and related groups. The trees are the source of resins, volatile oils, turpentine, tars, and pharmaceuticals.

Context: The association and position of artifacts, materials, and cultural features that are used by archeologists to interpret space, time, and culture.

Criterion of Abundance: If a large group of the specimens in a ceramic assemblage is represented by a single, homogenous, compositional fingerprint and the actual source of clay is unknown, then the criterion of abundance indicates that there is a high probability the group was produced locally or very near the site where it is most heavily represented.

Cumulic Soil: A soil formed in a setting experiencing relatively slow deposition, so that freshly introduced sediment is incorporated into the A horizon, leading to overthickening of the surface horizon. Cumulic soils are common in alluvial overbank and colluvial settings.

Cumlic Haplustolls: These soils have a thick mollic epipedon and are on flood plains and alluvial fans where fresh sediments have accumulated slowly enough to have become incorporated in the mollic epipedon. The mollic epipedon may be very thick, or there may be a series of thin buried epipedons. Consequently, there may not be either a cambic horizon or an accumulation of secondary carbonates in the soils. The natural vegetation is mostly grass and widely spaced trees.

Dehydroabietic Acid: This is a biomarker that indicates the presence of conifer products, which may have been introduced from firewood, resins or other conifer products. This acid can be detected in lipid residue analysis.

Dendrite: An oxide of manganese that has crystallized in a branching pattern as in the dark inclusions in moss agate.

Deposition: The accumulation of sediments or gravels laid down by natural agencies such as moving water, or artificial agencies such as dumping.

Diacylglycerols (DAG): Are components of oils and fats, lipid intermediates, and can be recovered from tissues using high temperature gas chromatography.

Diatoms: These are single-celled algae whose cellular contents are enclosed between two valves of silica that are preserved when the organism dies. Often diatoms are preserved in ponds and streams and important to stream ecology. Different taxa have different tolerances for extremes of temperature, salinity, water depth, water clarity, and nutrient concentrations and respond rapidly to changes in the environment. These are useful in reconstructing aquatic paleoenvironments.

Discriminant Analysis (DA): This is a statistical technique. This is used to predict group membership based on a linear combination of the interval variables. The procedure begins with a set of observations where both group membership and the values of the interval variables are known. The end result of the procedure is a model that allows prediction of group membership when only the 
interval variables are known. A second purpose of discriminant function analysis is an understanding of the data set, as a careful examination of the prediction model that results from the procedure can give insight into the relationship between group membership and the variables used to predict group membership.

Dolomite: A carbonate sedimentary rock consisting of more than 50 percent by weight of by areal percentage under the microscope of the mineral dolomite. Occurs in crystalline and noncrystalline forms, is clearly associated, and often interbedded, with limestone.

Effluent: This is the outflowing of water from a natural body of water, or from a man-made structure. Effluent is generally considered to be water pollution, such as the outflow from a sewage treatment facility or the wastewater discharge from industrial facilities.

Eluvial: The movement of materials such as clay or organic matter from a soil horizon by percolating water.

Eraillure Scar: A small enigmatic flake formed between the bulb of force and the bulbar scar.

Erosional Unconformity: A significant break or gap in the geological or depositional record, indicative of removal of the older unit prior to renewed deposition.

Ester: This is an organic compound that contains a carbonyl group linked to an alkyl group through an oxygen atom; organic compounds synthesized from a carboxylic acid and an alcohol in the presence of water.

Euclidean Distance: In mathematics, the Euclidean distance or Euclidean metric is the "ordinary" distance between two points that one would measure with a ruler, which can be proven by repeated application of the Pythagorean Theorem. By using this formula as distance,
Euclidean space becomes a metric space. The associated norm is called the Euclidean norm.

Eutrophic: Having waters rich in mineral and organic nutrients that promote a proliferation of plant life, especially algae, which reduces the dissolved oxygen content and often causes the extinction of other organisms. This is used in the discussion of diatoms.

Facies: A definable subdivision of a formal or informal stratigraphic unit.

FAMES: This is an abbreviation for fatty acid methyl esters (FAMES) and is prepared by treating the dry lipid with $3 \mathrm{~mL}$ of $0.5 \mathrm{~N}$ anhydrous hydrochloric acid in methanol $\left(68^{\circ} \mathrm{C} ; 60 \mathrm{~min}\right)$. This is part of the lipid residue analysis.

Fatty Acids: The major constituents of fats and oils (lipids) that occur in nature in plants and animals. They are insolubility in water and relatively abundant compared to other classes of lipids. Fatty acids may be absorbed into porous archeological materials during cooking, including heated rocks and ceramics, or ground into manos, metates, or mortar holes. Some of the major fatty acids are referred to as C12:0, C14:0, C15:0, C16:0, C16:1, C17:0, C18:0, C18:1w9, C18:1w11, C18:2.

Floodplain: A nearly level alluvial plain that borders a stream or river and is subject to periodic flooding.

Gas Chromatography (GC): This highly technical measuring instrument that separates and measures the amount of elemental components of a specific sample by the measurement of light passed through gas at regulated temperatures, which allows the detection of fatty acids at the nonogram $\left(1 \mathrm{X} \quad 10^{-9} \mathrm{~g}\right)$ level. High temperature gas chromatography is used to separate and assess a wide range of lipid components, including fatty acids, long-chain alcohols and hydrocarbons, sterols, waxes, terpenoids and triacylglycerols (Evershed et al. 2001). The molecular structure of 
separated components is elucidated by mass spectrometry (Evershed 2000).

Gas Chromatography-Mass Spectrometry (GCMS): This is an analytical technique that enables the mass analysis and identification of components separated from a sample by gas chromatography; an analytical technique that combines gas chromatography with mass spectrometry.

Gastropods: These are commonly known as snails and slugs, and a large taxonomic class within the phylum Mollusca.

Gelatinization: In regards to starch grains this is a morphological change (distortion of the original shape) in the grain caused by the exposure to heat and water when starches are cooked.

Geomorphology: That part of geography concerned with the form and development of the landscape.

Geophytes: These are plants with underground storage organ such as bulbs (i.e., onions, camas, and false garlic), tubers, roots, and rhizomes that are a reserve of carbohydrates, nutrients, and water. These storage organs can be collected, cooked, and eaten as part of the human diet. The study of these geophytes from an archeological site aids in determining the diet of the past occupants.

Glume: Pertains to small dry membranous chaffy bract found at the base of a grass spikelet or each flower in a sedge or related plant.

Hard/High Silica Polish: This is a residue that comes from the material that a stone tool came in contact with. This type of polish is generally produced when processing soft plants with high silica content in the plant tissues such as grasses, wood, reeds, and potentially soil. This polish was detected during high-powered microscopic usewear studies conducted during stone tools analysis.

HCL: Hydrochloric acid, which is the solution of hydrogen chloride $(\mathrm{HCl})$ in water. It is a highly corrosive, strong mineral acid and has major industrial uses.

Heating Element: This is an intentional, intact and localized spot were a human created a fire in an archeological site or component. This is generally evidenced by quantities of wood charcoal, prepared basin, lenses of charcoal or ash, and possibly an oxidation rim often accompanied by intentionally placed rocks, either lining the margins or directly amongst the charcoal. The function of this fire may reflect many different things, such as for heat to warm a person, to cook on, or to heat rocks for other uses. The specific contents may provide clues as to a more specific function or length of use.

High Temperature-Gas Chromatography (HTGC): This instrument is used to separate and assess a wide range of lipid components, including fatty acids, long-chain alcohols and hydrocarbons, sterols, waxes, terpenoids and triacylglycerols (Evershed et al. 2001). This is used with mass spectrometry (MS) to elucidate the molecular structure of separated components. Triacylglycerols, diacylglycerols and sterols can be used to distinguish animal-derived residues, which contain cholesterol and significant levels of both triacylglycerols, from plant-derived residues, indicated by plant sterols, such as $\beta$-sitosterol, stigmasterol and campesterol, and only traces of triacylglycerols.

Hilum: The scar on a seed, such as a bean, indicating the point of attachment to the funiculus. The nucleus of a starch grain.

Holocene: Geological time period spanning roughly the last 10,000-years before present. The Holocene is roughly equivalent to the Post-glacial period, and often referred to as the "Recent" period in geology. Many investigations consider the Holocene to be an interstadial in the ongoing Pleistocene epoch. 
Horizon: A discrete, relatively uniform layer in a soil profile that is typically parallel with the surface and formed as the result of pedogenic process.

Humates: These are substances formed from the biological and chemical breakdown of animal and plant life over time. Humates are made up of compounds and materials that plant life on earth absolutely needs for growth. Humates contain a mixture of organic acids, including humic acids, fulvic acids, macromolecules of amino acids, amino sugars, and peptides. The chemistry of humate is so complex it cannot really be broken down.

Humus: A dark, organic-rich substance consisting of decomposed organic material (animal or vegetable) and is found in the soil.

In Situ: An artifact in its original position that was placed or deposited within the landscape.

Integrity: This refers to the degree of intactness of archeological deposits, components, features, or artifacts.

\section{Instrumental Neutron Activation Analysis} (INAA): This is a method to determine the elemental composition of a sample (pottery or lithic) through the exposure of samples to a neutron flux from a nuclear reactor without the use of chemical separation. The exposure to neutrons produces several short- and long-lived radioactive isotopes that emit characteristic gamma rays. The energy of the emitted gamma rays provides information to identify the constituent elements, while the intensity of the emitted radiation is proportional to the amount of the element present in the sample. Gamma-ray spectroscopy is performed at different levels after irradiation to measure isotopes with different half-lives. The method is particularly sensitive to a large number of trace elements, including the rare earth elements, transition metals and others.

Inulin: This is a carbohydrate, a fructan is not digestible via acid hydrolysis, the typical way we digest carbohydrates such as starch.
Isomers: These are compounds with the same molecular formula that differ with respect to how the atoms are joined. Structural isomers differ with respect to the order in which atoms are joined. Stereoisomers differ with respect to the arrangement of atoms in space but the order in which the atoms are attached is identical.

Isotope: An atom of an element. One of two or more forms of a chemical element, differentiated by the number of neutrons contained in the nucleus.

Jasper: A dense, cryptocrystalline, opaque to slightly translucent variety of chert associated with iron oxide impurities that give the rock various colors. Most often red, but can be yellow, green, grayish-blue, brown, or black.

Knapping: A term used to describe the manufacturing of prehistoric chipped stone tools using different techniques, such as pressure and/or percussion methods, to chip/flake a target mass of material to form a useful tool.

Krotovina: A discrete, anomalous area visible in plan or profile in a soil resulting from the infilling of a void (e.g. a burrow or root) with dissimilar sediment. Some investigators prefer to limit the term to animal burrows, preferring the term "root trace" for filling related to decayed roots. Some krotovina are obvious, whereas others are tiny and may only be identified in thin sections.

Legume: A plant that produces a bean or seedpod in various forms consisting of one cell and/or two valves. Common legume plants across Texas include such plants as; mesquite, Texas ebony, various acacia, retama, Dalea sp., mimosa, and rattlebush.

Lipids: These are hydrophobic constituents of living tissues including fatty acids, alcohols, triacylglycerols, sterols, bile acids, and waxes. Lipids are present in tissues of all living organisms in varying proportions. These are insoluble in 
water, relatively easy to extract, and are readily amenable to separation and characterization.

Lithic: Means "of stone". This term is used by archeologists to refer to stone artifacts and the debris that result from the manufacture of stone artifacts.

Lithology: The scientific study and description of rocks, especially at the macroscopic level, in terms of their color, texture, and composition. The gross physical character of a rock or rock formation.

Little Barley: This is a short winter annual bunch grass with a scientific name of Hordeum pusillum in the Poaceae grass family. It has a rapid growth period with a brown seed that develops after spring and is available in the early summer. The seed head consists of flattened spikes. It is considered low in protein and is intolerant to shade. This grass has a low drought tolerance but can grow with only 10 inches of rain per year. It is considered a $\mathrm{C}_{3}$ grass (26.7\% ; Smith and Brown 1973) adapted to fine and medium soil (http://plants.usda.gov 2011).

Loam: This is soil composed of sand, silt, and clay in relatively even concentration (about 40-40-20\% concentration respectively). Loam soils generally contain more nutrients and humus than sandy soils, have better drainage and infiltration of water and air than silty soils, and are easier to till than clay soils.

Logrithm: This is used in mathematics in which the exponent (or power) to which a base must be raised to give a particular number. This is used in compositional analysis. It is to allow the data transformation when comparing major, minor, and trace elements to prevent variables with higher concentrations form having excess weight in calculations of many coefficients of similarity.

Macrobotanical: These are remains of plant tissues, such as wood, charcoal, and seeds that one can see with the naked eye.
Mahalanobis Distance: In statistics, Mahalanobis distance is a distance measure introduced by P. C. Mahalanobis in 1936. It is based on correlations between variables by which different patterns can be identified and analyzed. It is a useful way of determining similarity of an unknown sample set to a known one. It differs from Euclidean distance in that it takes into account the correlations of the data set and is scale-invariant, i.e., not dependent on the scale of measurements.

Major Element: One of fewer than 10 elements that typically occur in systems at levels greater than 1 wt. percent. This is a category of elements that includes silicon $(\mathrm{Si})$, Aluminum $(\mathrm{Al})$, sodium $(\mathrm{Na})$, Magnesium $(\mathrm{Mg})$, calcium $(\mathrm{Ca})$, iron $(\mathrm{Fe})$, and oxygen $(\mathrm{O})$.

Mano: This is a hand-held stone, usually sandstone or quartzite, used to grind plants such as corn, nuts, seeds, or other vegetable matter and sometimes other rocks. It is used in conjunction with a stone metate that plants are placed on to perform the grinding.

Manuport: An object, usually a rock, that was transported by humans to the place it was recovered, but its macroscopic appearance does not indicate it had been artificially altered to form a specific tool or other kind of artifact.

Mass Spectrometer (MS): This is an instrument used to produce molecular and elemental ions, sort them according to mass and detect abundances to establish the composition, determine molecular structure or measure isotopic ratios of specific elements.

Matrix: Refers to the sediments in which the artifacts at an archeological site are encased, or surrounds.

Melanize: This is too darken by incorporating humus. 
Mesic Condition: A relatively moist interval of time generally used in the context of climatic conditions.

Metate: A slab of rock in which vegetable matter is placed upon for the purpose of grinding. The natural surface becomes polished and a concave depression forms on the metate surface from continued grinding. The grinding stone used with the metate is called a mano.

Microdebitage: Any stone or lithic material from the manufacture of stone tools that is less than 4.0 $\mathrm{mm}$ in diameter. Microdebitage is often recovered in sieving or floating sediments from archeological deposits.

Microfauna: Any bone material from the fracturing of bones that is less than $4.0 \mathrm{~mm}$ in diameter. Microfauna is most often recovered in sieving or floating sediments from archeological deposits.

Microfossils: These include a variety of very tiny residues including such things as starch grains, diatoms, phytoliths, pollen, and organic remains that are only detectable and visible under highpowered microscopes.

Midden: This is somewhat of a catch-all term. It generally refers to an accumulation of cultural material such as a zone of burned rocks, and it is often used to refer to a thick accumulation of mixed cultural material in a vertical zone.

Minor Element: One of about seven elements that typically occur in all systems at level between 0.1 and $1 \mathrm{wt}$ percent. This includes hydrogen $(\mathrm{H})$, potassium (K), sulfur (S), carbon $(\mathrm{C}$, phosphorus $(\mathrm{P})$, titanium Ti), and Manganese (Mn).

Mollisols: These are soils that form in semi-arid to semi-humid areas under grasslands. They are characterized by a thick, dark surface horizon.

Molar Solutions: A Molar (M) is a solution that contains one mole of solute in each liter of solution.
A mole is the molecular weight expressed as grams. Therefore, $1 \mathrm{M}=1 \mathrm{~g}$ of molecular weight of solution per liter of solution.

Mussel Shells: This is the outer shell that protects a meaty soft mussel on the interior. The shell is composed of inorganic and organic components. Three major layers combine to make up the shell and include the thin outermost layer that is called the periostracum or epidermis. Underlying the epidermis is the prismatic layer made of calcium carbonate (calcite). The third layer is the innermost and is the nacre or mother-of-pearl layer, which is also composed of calcium carbonate in the form of calcite, aragonite, or both in alternating layers.

Neutron: This is an electrically neutral subatomic particle that occurs in the nucleus of an atom. It is also a subatomic particle that is slightly larger than a proton.

Organic: Compounds that contain carbon and are associated with living organisms. Materials or objects that contain organic carbon can be radiocarbon dated.

Overbank Deposits: The deposition of fine silts and clay particles that are left on terrace tops and banks when water in creeks exceeds the capacity of the channel and drops the suspended sediments in the lower energy environment. Overbank depositional processes usually cause minimal movement to large objects on the terrace top.

Oxidation: A chemical process wherein oxygen is added to minerals or other compounds; weathering oxidizes minerals; burning wood and rusting metal are types of oxidation.

Paleoenvironment: Ancient or past environments.

Paleosol: Generally refers to a soil that developed an A horizon and was subsequently buried by younger deposits.

Palimpsest: Archeologically, refers to the inability to distinguish and separate material remains from 
repeated occupations by a succession of cultural events of different ages due to their deposition and intermixing over time on relatively stable surfaces. Some palimpsest assemblages are buried following a long period of exposure.

Palynology: The study of fossil palynomorphs (pollens and spores) that are produced by plants. Commonly used to reconstruct the floral communities in paleoenvironments.

Parching: To dry or roast by exposing to heat or to make extremely dry.

Parenchyma Residues: The functional parts of an organ or the thin-walled cells of the ground plant. These can be detected during phytolith analysis.

Ped: A unit of soil structure such as an aggregate, crumb, prism, block, or granule, formed by natural processes.

Pedogenesis: The dynamic process of soil formation and development, which typically leads to the formation of a darkened, organic-rich A horizon at or near the surface, and the downward movement of fine clays into, and/or the formation of carbonate nodules within, the underlying B horizons.

Pedoturbation: A general term used to describe soil that has been mixed.

Pee Dee Belmnite: A limestone found in Southern Carolina used as the international standard for various compositional (carbon and oxygen isotopic and elemental) analyses.

Phase: A group of related archeological traits (e.g., artifacts, features) that contain similar cultural material and date to one relatively narrow time period within a limited region.

pH: This is shorthand for the standard numerical designation of acidity and alkalinity commonly used in reference to soils. A neutral $\mathrm{pH}$ value (as in distilled water) is 7.0. Lower and higher values are acidic and base, respectively.

Photosynthesis: This is the process used by green plants and certain microorganisms to transform carbon dioxide and water into sugar and oxygen.

Phytolith: These are microscopic, inorganic siliceous bodies/residues that form in plant cells and frequent mirror parent cell shape. They are produced in multiple shapes and sizes. After the plant dies, the silica bodies become part of the mineral component of soils. A single plant may produce many different phytolith forms. A single phytolith form may be produced by a number of plant taxa. Phytoliths may survive for thousands of years and provide evidence of past plants.

Planktonic Diatoms: Those species that live suspended in the water column.

Pleistocene: The first epoch, which along with the Holocene Epoch constitutes the Quaternary period, spanning the time between roughly 2.0 or 1.65 million years ago and 10,000-years ago. Characterized by repeated continental glaciations, the Pleistocene witnessed the evolution of modern humans.

Polyunsaturated Fatty Acids: Pertaining to longchain carbon compounds (e.g., C18:2) like fats with multiple double bonds. These fats are very unstable and degrade very rapidly over time. These are detected in archeological samples during lipid residue analysis.

Pressure Flaking: A method used to shape stone tools through the application of force applied by pushing rather than striking. This is generally part of the final stages of finishing a stone tool.

Principal Component Analysis (PCA): This is a pattern recognition technique used for reducing the dimensionality of multivariate data, similar to factor analysis. It uses all the variables measured in 
a sample and calculates the variation among those variables.

Profile: A cross-sectional exposure of the sequence of horizons that make up a soil or a sequence of sedimentary deposits. It can be the result of either natural erosional down cutting or an artificial excavation.

Provenience: The specific vertical and horizontal location of where an object is found.

Quaternary: The second period, which along with the Tertiary Period, make up the Cenozoic Era, encompassing the Pleistocene and Holocene epochs; roughly the last 2.0 or 1.65 million years.

Rabdotus sp.: These are gastropods of the family of Bulimulidae. These are primarily open grassland to sparsely wooded area species.

Radiocarbon Dating: The process of determining the age of a sample based on the amount of radioactive carbon (carbon 14) retained in that object.

Raphides: Needle-shaped crystals in a plant cell, typically of calcium oxalate. These are small (30 to $500 \mu \mathrm{m})$ crystals, generally with points on the ends and of similar lengths. They are often found in plants of the Agavaceae family such as sotol, yucca, agave, and lechuguilla. They are not diagnostic of any particular plant. Bohrer (1987) and Kwiatkowski (1992) believe that only agave contain these crystals. In contrast, Dering (2003) believes raphides occur in a variety of Agavaceae including sotol, yucca, agave, and beargrass.

Rare Earth Elements (REE): Any one of a group of 17 elements that includes scandium (Sc), yttrium (Y), and those from atomic number 57 to 71 .

Retouch: A technique of chipped stone artifact manufacture in which pressure flaking is used to detach small flakes to sharpen or otherwise modify the edge of a stone tool.
Salinity: This is the saltiness or dissolved salt content of a body of water. It is a general term used to describe the levels of different salts such as sodium chloride, magnesium and calcium sulfates, and bicarbonates. Salinity may also refer to the salt content of soil.

Saprobity: This refers to the presence of biodegradable organic matter and low oxygen concentrations.

Saturated Fatty Acids: Each carbon in the chain is connected to its neighboring carbon by a single bond, which makes them relatively stable. The most abundant saturated fatty acids have chain-lengths of either, 14, 16, or 18 carbons. Mammal fats consist primarily of saturated fatty acids and are solid at room temperature. These are detected in archeological samples during lipid residue analysis.

Silt: A particle size that has a range from $0.06 \mathrm{~mm}$ to $0.002 \mathrm{~mm}$. These are smaller than sand grains and larger than clay particles.

Siliceous: Pertaining to silica, as in silicon dioxide, the most common chemical constituent on earth, and the dominant component of chert and quartz.

Site Structure: The spatial distribution of features, artifacts, and debris across a single occupation (or within a component) of an archeological site that is used to reconstruct manufacturing, maintenance, processing, production, and disposal activities at specific loci, and the spatial ways prehistoric groups organized their space at a site.

Slackwater: Water that is essentially still/unstressed or with no movement either way.

Slickensides: This term is used to describe polished, grooved surfaces that occur along shear planes within the soil. These shear planes result from the shrink-swell action of smectite clays.

Sodium Hydroxide (NaOH): Also known as lye and caustic soda, sodium hydroxide forms a strong alkaline solution when dissolved in a solvent such 
as water. However, only the hydroxide ion is basic. It is used in many industries, mostly as a strong chemical base. Pure sodium hydroxide is white.

Soil Horizon: A layer of soil, approximately parallel to the surface, having distinct characteristics produced by soil-forming processes. In the identification of soil horizons an upper case letter (i.e., A, B, C, R, and O) represents the major horizons with $\mathrm{A}$ at the top. Lower case letters that follow the upper case letters represent subdivisions of the major horizons.

Soluble Inorganic Residues: These are silica gel residues that build up with moisture availability on the utilized edges of stone tools, and that form discrete microplates as tool use progresses. Impervious to most acids and strong bases, they were are quite commonly found during use-wear analysis of stone tools and are valuable indicators of tool use due to their long-term stability, and effects on the microgemometry of a tool edge that indicate kinds of motion during use. They exhibit flow characteristics of a viscous liquid and desiccation cracks as they harden.

Stable Isotope: An isotope is not subjected to radioactive decay, it is stable. This contrasts with radioactive isotopes such as carbon $\left(\mathrm{C}^{13}\right)$, oxygen $\mathrm{O}^{18}$, or nitrogen $\left(\mathrm{N}^{15}\right)$ isotopes that decay over time.

Starch: Starch is produced by all green plants for energy storage and is a major food source for humans. Pure starch is a white, tasteless and odorless powder that is insoluble in cold water or alcohol. Starch can be used as a thickening, stiffening or gluing agent when dissolved in warm water, giving, for example, wheat paste. In photosynthesis, plants use light energy to produce glucose from carbon dioxide. The glucose is stored mainly in the form of starch granules. Toward the end of the growing season, starch accumulates in twigs of trees near the buds. Fruit, seeds, rhizomes, and tubers store starch to prepare for the next growing season.
Sterols: These are structural lipids that are present in cell membranes and contain the perhydrocyclopentanophenanthrene ring system. Sterols are a special king of alcohol that serve as precursors to a wide variety of products known as steroids. The cholesterol is the major sterol in animal tissue. Campesterol, stigmasterol and sitosterol are sterols found in plant tissue.

Stigmasterol: This and sitosterol are sterols found in plant tissue and can be detected in lipid analysis.

Stratigraphy: The study of layering in rocks and/or sediments, and how the layers correlate to each other.

Striae: These are tiny, thin, narrow grooves, channels, or lines, often called striations. Here, they were observed during high-powered microscopic use-wear analysis on stone tools and are an indication of the direction of the movement of the tools during their use. They were observed under high magnification in the residues left on the tools.

Terrace: In geologic terms this is an old alluvial plain that is generally flat and borders a river, stream, lake, or sea. Terraces are recognized by different elevations and generally labeled $\mathrm{T}_{0}, \mathrm{~T}_{1}$ and $\mathrm{T}_{2}$ from lowest to highest.

Trace Elements: Chemical elements, such as zinc, manganese, and iron that typically occur in soils and other materials, when present in extremely small amounts. Triacylglycerol (TAGs): This is a glycerol molecule to which three fatty acids are bounded through ester linkages. These can be detected in lipid analysis.

Triticeae: This is a tribe within the Pooideae subfamily of grasses that includes genera with many domesticated species. Major crop genera are found in this tribe including wheat, barley, and rye.

Trophic State Index: This refers to the presence of inorganic nutrients such as nitrogen, phosphorus, silica and carbon or in organic forms. This is a 
measure of the ecological potential of the aquatic environment to sustain species at different levels in the food chain. Terms used to describe the trophic state; oligotrophic is nutrient poor, mesotrophic indicates moderate nutrient concentrations, eutrophic is nutrient rich, and eurytrophic is indifferent to nutrients.

Turbation: Disturbance to natural matrix deposits generally caused by biological agents (burrowing rodents, insects, worms, and plant roots) and natural (soil creep, desiccation crack displacement, frost heaving, landslides, etc.) processes. These actions tend to move cultural objects in the ground.

Tuber: This is the thick, fleshy underground stem of a plant. This stem serves as the primary storage organ of nutrients that stores food over winter and produces new growth in spring.

Type: This is a group of similar items (ceramic sherds or projectile points) all of which are more or less the same.

Udic Haplusterts: These are soils that form on nearly flat alluvial terraces. The alluvial parent material is both clay-rich and calcareous. The high shrink-swell capacity of this soil is apparent from the slickensides present throughout the lower profile.

Ultraviolet Light: The wave length of light above that is usually detected by the human eye and that fluoresces various kinds of minerals and emits distinctive colors. Here, a multiband light source (UV light 254/366 nm Model UVGI-58) was used to investigate the visual fluorescence of culturally modified stones to help in identifying their source and detect new/recent scars from old flake scars.

Unconformity: Stratigraphic term for a boundary or break created by a depositional hiatus. This boundary separates younger strata from older strata. An unconformity is usually caused by erosion and therefore deposits are missing.
Unsaturated Fatty Acids: These types of fatty acids contain at least one carbon-carbon double bond or point of unsaturation. That point of unsaturation is susceptible to additional reactions. Unsaturated fatty acids are the primary constituents of plant and fish oils and tend to be in liquid-state at room temperature. Their chain-lengths vary with a minimum of 12 carbons but most common ones contain at least 18 carbons.

Use-wear: The high-powered microscopic evidence on a stone tool that was created from sustained use. The wear may appear as striations, tiny nicks, abrasive particles, polish, rounding, soluble inorganic residues, etc. The accompanying use-wear study used magnification between 100x and 500x to observe wear and edge-modification on selected artifacts. This detailed analysis contributes to our understanding of the function of tools and potentially substances that tools were used on.

Uvalde Gravel: A gravel deposit throughout much of south, central and east Texas attributed to the late Miocene to early Pleistocene. The deposits are composed of pebbles, cobbles, and boulders of vein quartz, quartzite, chert, jasper, silicified wood and limestone. The ultimate source of the lithology indicates the Llano Uplift likely the Ogallala Formation (see Byrd 1971 for more details).

Variance-covariance Matrix: This is the matrix of covariances between all pairs of measured variables in a study.

Vector: This is a quantity that has both direction and magnitude and used in INAA analysis.

Vertisols: These are deep, mature clay-rich soils that shrink and swell as their moisture content changes. This natural process can cause artifacts to be displaced.

Waxes: These are long-chain fatty acids and longchain alcohols that form protective coatings on skin, fur, feathers, leaves and fruit, also resist decay. These can be detected in lipid analysis. 
Wildrye (Elymus sp.): A common grass throughout the Plains of the United States, from Mexico to Canada and is all across Texas. The seeds of this genus are large and it possesses a large distinctive starch grain. This is a cool season $\mathrm{C}_{3}$ grass (ca. $-27.6 \%$, $-27.1 \%$, Bender 1971) that produces short cell phytoliths. The seeds are available during the summer and fall.
Xeric Condition: A dry or relatively arid condition often in reference to climatic conditions.

Xerophic Plants: These are plants that have adapted to survive in an environment that lacks water, such as a desert. These include cactus, sotol, yucca, agave, and lechuguilla, and others. 


\section{APPENDIX A: RADIOCARBON ASSAY RESULTS}

Prepared for:

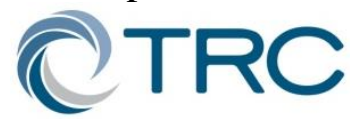

TRC Environmental Corporation

505 East Huntland Drive, Suite 250

Austin, Texas 78752

Prepared by:

Darden Hood

Beta Analytic Inc.

4985 S.W. 74 Court

Miami, Florida 33155

2012 
This page intentionally left blank. 


\section{RADIOCARBON ASSAY RESULTS}

\section{BETR}

4985 S.W. 74 COURT

MIAMI, FLORIDA, USA 33155

PH: 305-667-5167 FAX:305-663-0964

beta@radiocarbon.com

REPORT OF RADIOCARBON DATING ANALYSES

Dr. James Abbott

Texas Department of Transportation
Report Date: $7 / 13 / 2012$

Material Received: 6/22/2012

\begin{tabular}{|c|c|c|c|}
\hline Sample Data & $\begin{array}{c}\text { Measured } \\
\text { Radiocarbon Age }\end{array}$ & $\begin{array}{c}13 \mathrm{C} / 12 \mathrm{C} \\
\text { Ratio }\end{array}$ & $\begin{array}{c}\text { Conventional } \\
\text { Radiocarbon Age }\left(^{*}\right)\end{array}$ \\
\hline $\begin{array}{l}\text { Beta - } 324463 \\
\text { SAMPLE : MM382 53-7 Test Unit } \\
\text { ANALYSIS : AMS-Standard delive } \\
\text { MATERIAL/PRETREATMENT : } \\
\text { 2 SIGMA CALIBRATION : }\end{array}$ & $\begin{array}{l}\qquad 3270+/-30 \mathrm{BP} \\
3130-140 \mathrm{cmbs} \text { Snail shells } \\
\text { ry } \\
\text { (shell): acid etch } \\
\text { Cal BC } 1920 \text { to } 1750 \text { (Cal BP } 3870 \text { to } 3700\end{array}$ & $\begin{array}{l}-10.1 \mathrm{o} / \mathrm{oo} \\
0)\end{array}$ & $3510+/-30 \mathrm{BP}$ \\
\hline $\begin{array}{l}\text { Beta - } 324464 \\
\text { SAMPLE : MM382 58-7 Test Unit } \\
\text { ANALYSIS : AMS-Standard delive } \\
\text { MATERIAL/PRETREATMENT : } \\
\text { 2 SIGMA CALIBRATION : }\end{array}$ & $\begin{array}{l}\qquad 2320+/-30 \mathrm{BP} \\
1130-140 \mathrm{cmbs} \text { Snail shells } \\
\text { ry } \\
\text { (shell): acid etch } \\
\text { Cal BC } 800 \text { to } 760 \text { (Cal BP } 2750 \text { to } 2710) \mathrm{A}\end{array}$ & $\begin{array}{l}-9.6 \mathrm{o} / \mathrm{oo} \\
\text { AND Cal BC } 6\end{array}$ & BP 2630 to 2620 ) \\
\hline $\begin{array}{l}\text { Beta - } 324465 \\
\text { SAMPLE : MM382 60-7 Test Unit } \\
\text { ANALYSIS : AMS-Standard delive } \\
\text { MATERIAL/PRETREATMENT : } \\
\text { 2 SIGMA CALIBRATION : }\end{array}$ & $\begin{array}{l}\qquad 2420+/-30 \mathrm{BP} \\
2130-140 \mathrm{cmbs} \text { Snail shells } \\
\text { ry } \\
\text { (shell): acid etch } \\
\text { Cal BC } 890 \text { to } 880 \text { (Cal BP } 2840 \text { to } 2820 \text { ) }\end{array}$ & AND Cal BC 8 & BP 2800 to 2750 ) \\
\hline $\begin{array}{l}\text { Beta - } 324466 \\
\text { SAMPLE : MM382 89-7 Test Unit } \\
\text { ANALYSIS : AMS-Standard delive } \\
\text { MATERIAL/PRETREATMENT : } \\
\text { 2 SIGMA CALIBRATION : }\end{array}$ & $\begin{array}{l}\qquad 3800+/-30 \mathrm{BP} \\
9110-120 \mathrm{cmbs} \text { Snail shells } \\
\text { ty } \\
\text { (shell): acid etch } \\
\text { Cal BC } 2830 \text { to } 2820(\mathrm{Cal} \mathrm{BP} 4780 \text { to } 47\end{array}$ & $-10.3 \mathrm{o} / \mathrm{oo}$ & $4040+/-30 \mathrm{BP}$ \\
\hline
\end{tabular}

Dates are reported as RCYEP (radiocarbon years before present, "present" = AD 1950). By international convention, the modern reference standard was $95 \%$ the $14 \mathrm{C}$ activity of the National Institute of Standards and Technology (NIST) Oxalic Acid (SRM 4990C) and calculated using the Libby $14 \mathrm{C}$ half-life (5568 years). Quoted errors represent 1 relive standard deviation statistics (68\% probability) (1) counting errors based on the combined measurements of the sample, background, and modem reference standards. Measured $13 \mathrm{C} / 12 \mathrm{C}$ ratios (delta 13C) were calculated relative to the PDB-1 standard.
The Conventional Radiocarbon Age represents the Measured Radiocarbon Age corrected for isotopic fractionation, calculated using the delta $13 \mathrm{C}$. On rare occasion where the Conventional Radiocarbon Age was calculated using an assumed delta $13 \mathrm{C}$ the ratio and the Conventional Radiocarbon Age will be followed by "**" The Conventional Radiocarbon Age is not calendar calibrated The Conventional Radiocarbon Age is not calendar calibrated. from avallable, the Calendar Calibrated result is calculated "Two the Conventional Radiocarbon Age and is listed as the "Two Sigma Calibrated Result" for each sample. 


\section{BETR BETA ANALYTIC INC.}

DR. M.A. TAMERS and MR. D.G. HOOD

4985 S.W. 74 COURT

MIAMI, FLORIDA, USA 33155

PH: 305-667-5167 FAX:305-663-0964

beta@radiocarbon.com

\section{REPORT OF RADIOCARBON DATING ANALYSES}

Dr. James Abbott

Report Date: $7 / 13 / 2012$

\begin{tabular}{|c|c|c|c|}
\hline Sample Data & $\begin{array}{c}\text { Measured } \\
\text { Radiocarbon Age }\end{array}$ & $\begin{array}{c}13 \mathrm{C} / 12 \mathrm{C} \\
\text { Ratio }\end{array}$ & $\begin{array}{c}\text { Conventional } \\
\text { Radiocarbon Age }\left(^{*}\right)\end{array}$ \\
\hline $\begin{array}{l}\text { Beta - } 324467 \\
\text { SAMPLE : MM382 99-7 Test Unit } \\
\text { ANALYSIS : AMS-Standard delive } \\
\text { MATERIAL/PRETREATMENT : } \\
2 \text { SIGMA CALIBRATION : }\end{array}$ & $\begin{array}{l}\qquad 3810+/-30 \mathrm{BP} \\
\text { it } 9130-140 \mathrm{cmb} \text { s Snail shells } \\
\text { ery } \\
\text { (shell): acid etch } \\
\text { Cal BC } 2850 \text { to } 2810 \text { (Cal BP } 4 \\
\text { Cal BC } 2700 \text { to } 2570 \text { (Cal BP } 4\end{array}$ & $\begin{array}{l}-8.7 \mathrm{o} / \mathrm{oo} \\
\text { AND Cal BC } \\
\text { AND Cal BC }\end{array}$ & $\begin{array}{l}\text { (Cal BP } 4690 \text { to } 4680) \\
(\text { Cal BP } 4470 \text { to } 4450)\end{array}$ \\
\hline $\begin{array}{l}\text { Beta - } 324468 \\
\text { SAMPLE : MM382 } 127-2 \text { Test Un } \\
\text { ANALYSIS : AMS-Standard delive } \\
\text { MATERIAL/PRETREATMENT : } \\
2 \text { SIGMA CALIBRATION : }\end{array}$ & $\begin{array}{l}\qquad 3220+/-30 \mathrm{BP} \\
\text { nit } 7140-150 \mathrm{cmbs} \text { Bone } \\
\text { ery } \\
\text { (bone collagen): collagen extra } \\
\text { Cal BC } 1680 \text { to } 1510 \text { (Cal BP } 3\end{array}$ & $-19.4 \mathrm{o} / \mathrm{oo}$ & $3310+/-30 \mathrm{BP}$ \\
\hline
\end{tabular}

Dates are reported as RCYEP (radiocarbon years before present, "present" = AD 1950). By international convention, the modern reference standard was $95 \%$ the $14 \mathrm{C}$ activity of the National Institute of Standards and Technology (NIST) Oxalic Acid (SRM 4990C) and calculated using the Libby $14 \mathrm{C}$ half-life ( 5568 years). Quoted errors represent 1 relative standard deviation statistics $(68 \%$ probability) counting errors based on the combined measurements of the sample, background, and modern reference standards. Measured $13 \mathrm{C} / 12 \mathrm{C}$ ratios (delta 13C) were calculated relative to the PDB-1 standard.
The Conventional Radiocarbon Age represents the Measured Radiocarbon Age corrected for isotopic fractionation, calculated using the delta $13 \mathrm{C}$. On rare occasion where the Conventional Radiocarbon Age was calculated using an assumed delta $13 \mathrm{C}$ the ratio and the Conventional Radiocarbon Age will be followed by "*" The Conventional Radiocarbon Age is not calendar calibrated When available, the Calendar Calibrated result is calculated from the Conventional Radiocarbon Age and is listed as the "Two Sigma Calibrated Result" for each sample. 


\section{CALIBRATION OF RADIOCARBON AGE TO CALENDAR YEARS}

(V ariables: $\mathrm{C} 13 / \mathrm{C} 12=-10.1:$ lab. mult $=1$ )

Laboratory num ber: Beta-324463

Conventional radiocarbon age: $\quad 3510 \pm 30$ B P

2 Sigm a calibrated result: Cal BC 1920 to 1750 (Cal BP 3870 to 3700 ) ( $95 \%$ probability)

Intercept data

Intercepts of radiocarbon age with calibration curve:

Cal BC 1880 (Ca1 BP 3830) and Ca1 BC 1840 (Ca1 BP 3790) and Cal BC 1830 (Cal BP 3780)

1 Sigma calibrated results: Cal BC 1890 to 1860 (Cal BP 3840 to 3810 ) and (68\% probability) Ca1 BC 1850 to 1770 (Ca1 BP 3800 to 3720 )

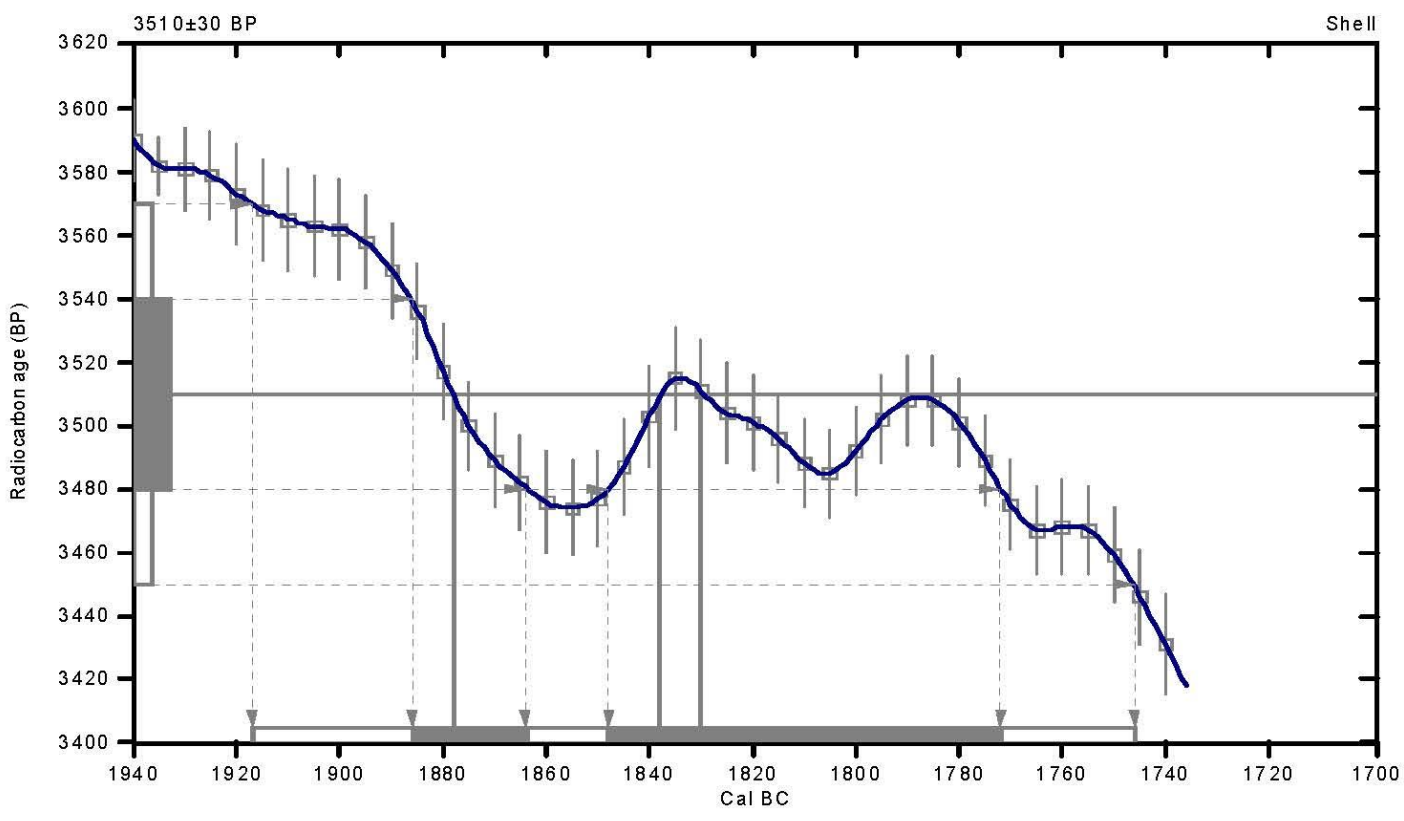

References:

Database used INTCALO9

References to INTCAL09 database

Heaton, et.al.,2009, Radiocarbon 51(4):1151-1164, Reimer,et.al, 2009, Radiocarbon 51(4):1111-1150, Stuiver, et.al,1993, Radiocarbon 35(1):137-189, Oeschger,et.al.,1975, Tellus 27:168-192

Mathematics used for calibration scenario

A Simplified Approach to Calibrating C14 Dates

Talma, A. S. Vogel, J. C. 1993, Radiocarbon 35 (2):317-322

\section{Beta Analytic Radiocarbon Dating Laboratory}

4985 s.W. 74th Court, Miami, Florida 33155・Tel:(305)667-5167・Fax: (305)663-0964・E-Mail: beta@ radiocarbon.com 


\section{CALIBRATION OF RADIOCARBON AGE TO CALENDAR YEARS}

(V ariables: $\mathrm{C} 13 / \mathrm{C} 12=-9.6: 1 \mathrm{ab}, \mathrm{mult}=1$ )

Laboratory number: Beta-324464

Conventional radiocarbon age: $2570 \pm 30 \mathrm{BP}$

2 Sigm a calibrated results: Cal BC 800 to 760 (Cal BP 2750 to 2710 ) and (95\% probability) Cal BC 680 to 670 (Cal BP 2630 to 2620)

Intercept data

Intercept of radioca rb on age with calibration curve:

Ca1 BC 790 (Ca1 BP 2740)

1 Sigma calibrated result: Ca1 BC 800 to 770 (Ca1 BP 2740 to 2720)

( $68 \%$ probability)

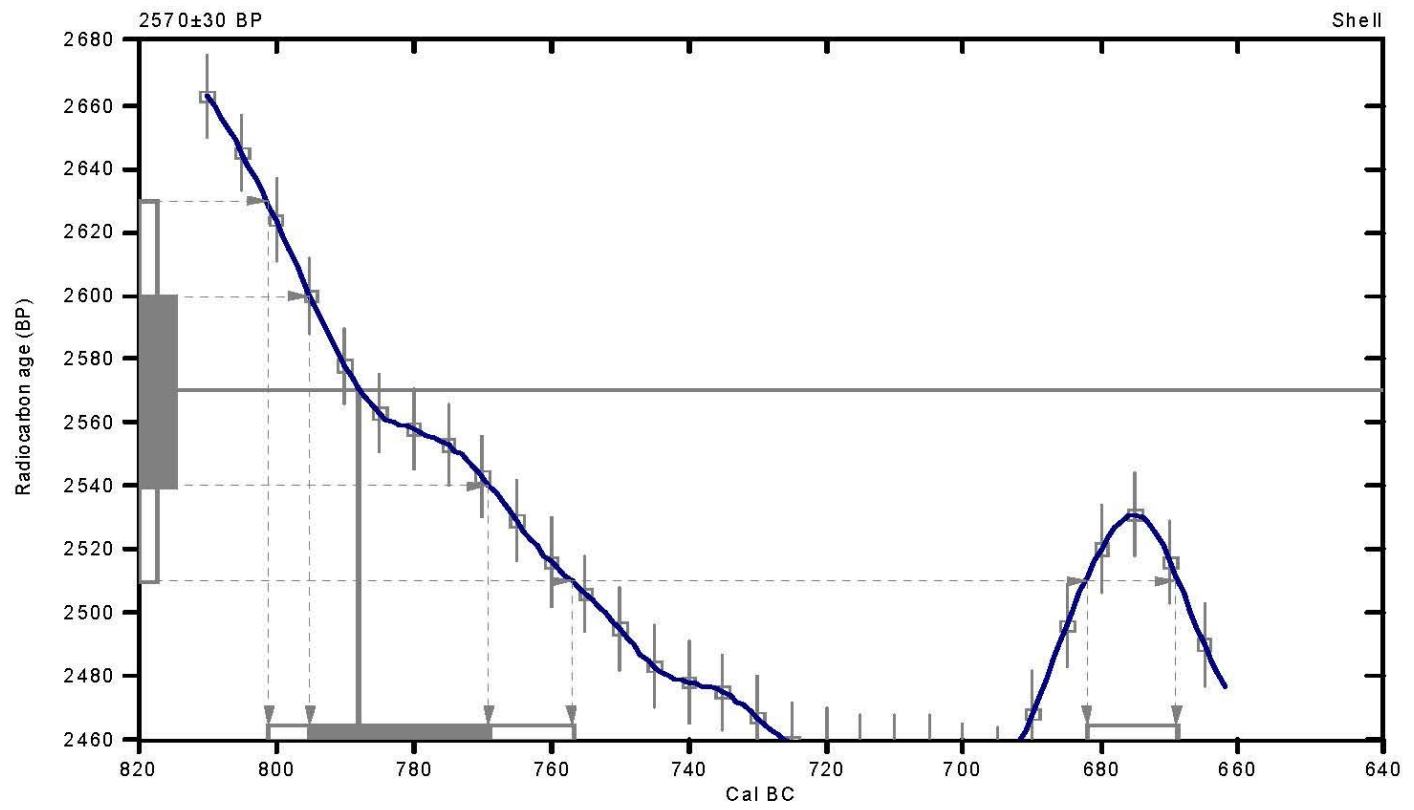

References:

Database used

$$
\text { INTCALO } 9
$$

References to INTCALO9 database

Heaton, et.al.,2009, Radiocarbon 51(4):1151-1164, Reimer,et.al, 2009, Radiocarbon 51(4):1111-1150,

Stuiver, et.at,1993, Radiocarbon 35(1):137-189, Oeschger,et.al, 1975, Tellus 27:168-192

Mathematics used for calibration scenario

A Simplified Approach to Calibrating C14 Dates

Talma, A. S., Vogel, J. C., 1993, Radiocarbon 35(2):317-322

\section{Beta Analytic Radiocarbon Dating Laboratory}

4985 S.W. 74th Court, Miami, Florida 33155 - Tel: (305)667-5167 • Fax: (305)663-0964・E-Mail: beta@ @adiocarbon.com 


\section{CALIBRATION OF RADIOCARBON AGE TO CALENDAR YEARS}

(V ariables: $\mathrm{C} 13 / \mathrm{C} 12=-9.8: 1 \mathrm{ab} \cdot \mathrm{mult}=1)$

Laboratory number: Beta-324465

Conventional radiocarbon age: $\quad 2670 \pm 30 \mathrm{BP}$

2 Sigm a calibrated results: Cal BC 890 to 880 (Cal BP 2840 to 2820 ) and (95\% probability) Cal BC 850 to 800 (Cal BP 2800 to 2750)

Intercept data

Intercept of radiocarb on age with calibration curve: Ca1 BC 810 (Ca1 BP 2760)

1 Sigma calibrated result: ( $68 \%$ probability)

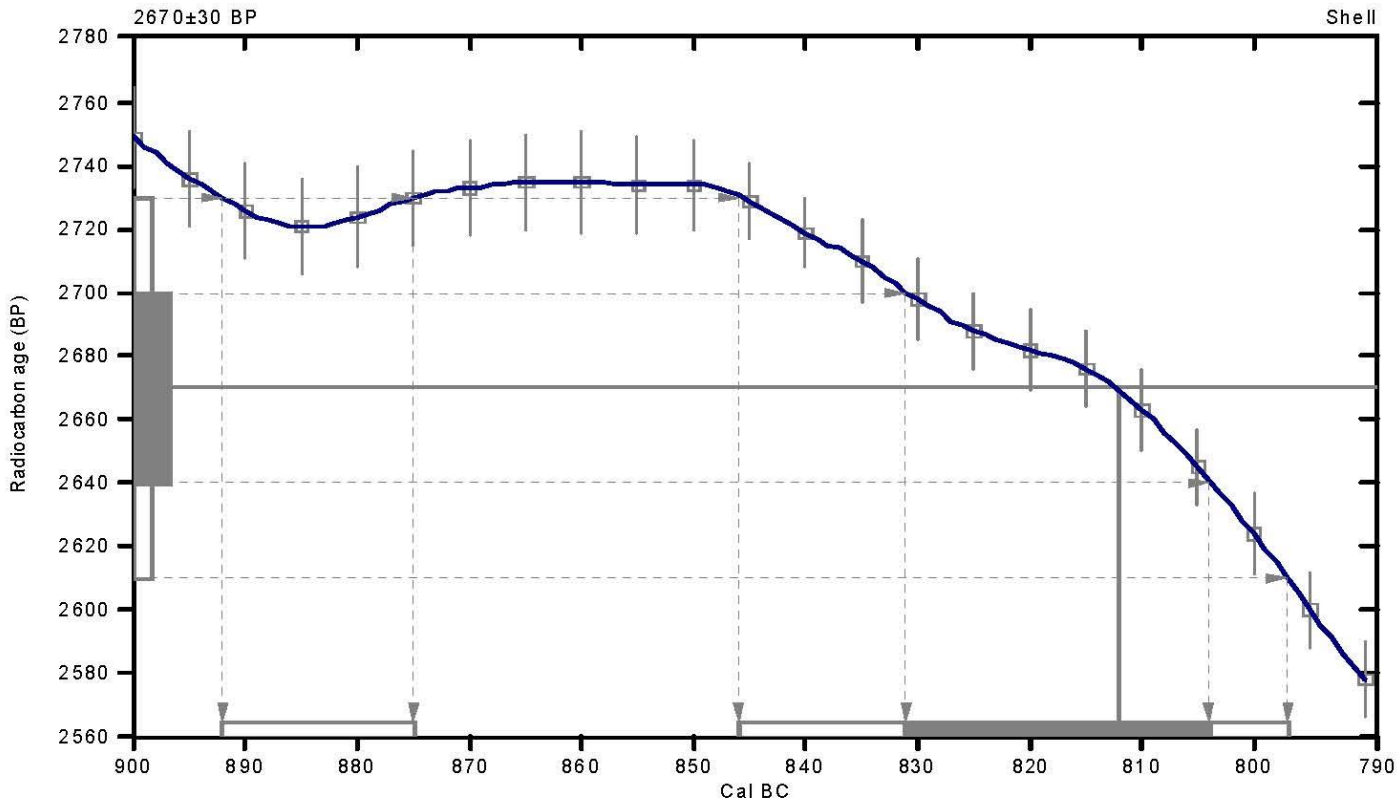

References:

Database used INTCALO 9

References to INTCALO9 database

Heaton, et.al.,2009, Radiocarbon 51(4):1151-1164, Reimer,et.al, 2009, Radiocarbon 51(4):1111-1150, Stuiver, et.al,1993, Radiocarbon 35(1):137-189, Oeschger,et.al., 1975, Telhis 27:168-192 Mathematics used for calibration scenario

A Simplified Approach to Calibrating C14 Dates

Talma, A. S., Vogel, J. C., 1993, Radiocarbon 35(2):317-322

\section{Beta Analytic Radiocarbon Dating Laboratory}

4985 s. W. 74th Court, Miami, Flonda 33155 - Tel:(305)667-5167•Fax:(305)663-0964・E-Mail: beta@ radiocarbon.com 


\section{CALIBRATION OF RADIOCARBON AGE TO CALENDAR YEARS}

(V ariables: $\mathrm{C} 13 / \mathrm{C} 12=-10.3: 1 \mathrm{ab} . \mathrm{mult}=1$ )

Laboratory number: Beta-324466

Conventional radiocarbon age: $\quad 4040 \pm 30 \mathrm{BP}$

2 Sigm a calibrated results: Cal BC 2830 to 2820 (Cal BP 4780 to 4770 ) and (95\% probability) Cal BC 2620 to 2480 (Cal BP 4580 to 4420)

Intercept data

In tercepts of radiocarbon age

with calibration curve: Ca1 BC $2570(\mathrm{Ca} 1 \mathrm{BP} 4520)$ and

Ca1 BC 2510 (Cal BP 4460) and

Cal BC 2500 (Cal BP 4450)

1 Sigma calibrated results: Ca1 BC 2580 to 2560 (Cal BP 4530 to 4510 ) and (68\% probability) Ca1 BC 2530 to 2490 (Cal BP 4480 to 4440 )

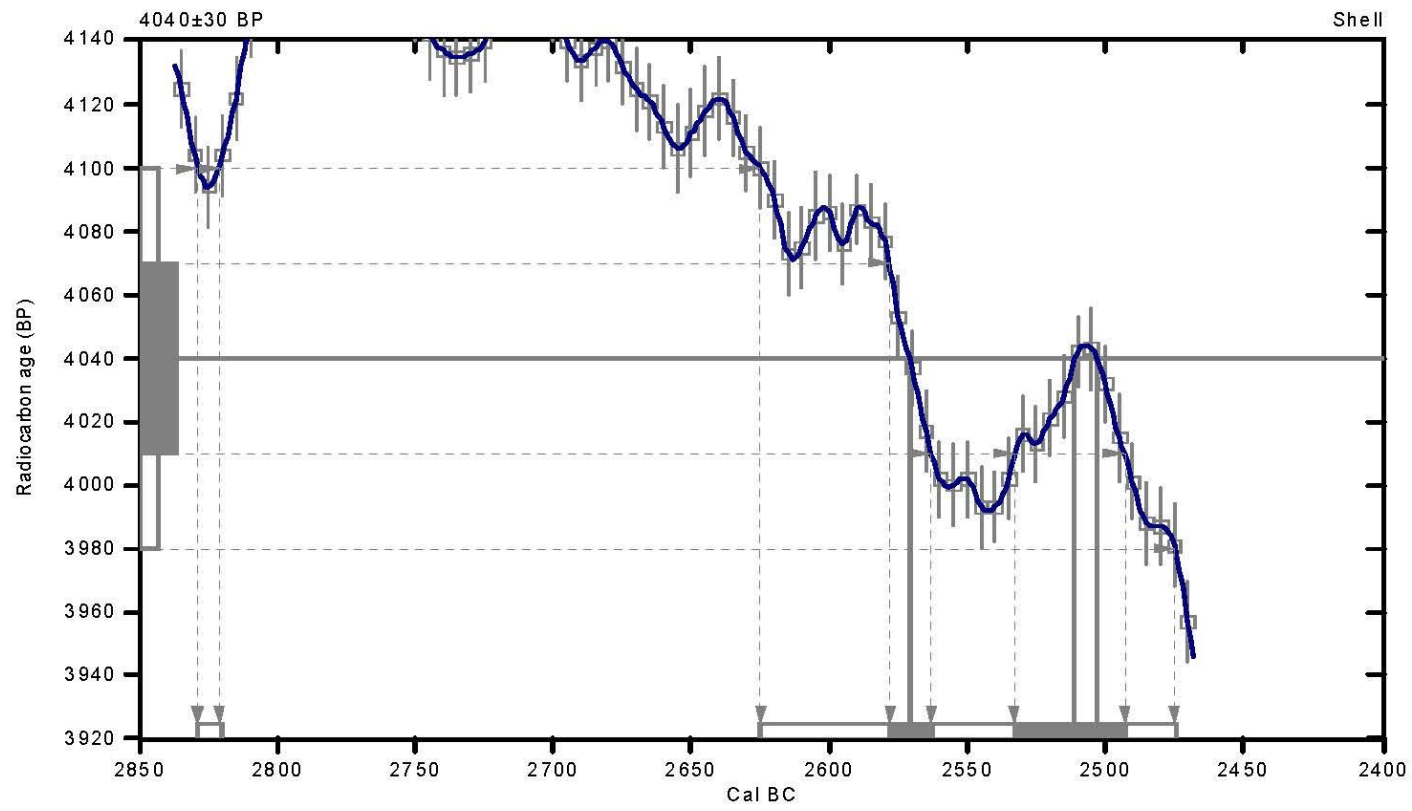

References:

Database used INTCALO9

References to INTCAL09 database

Heaton, et.al.,2009, Radiocarbon 51(4):1151-1164, Reimer,et.al, 2009, Radiocarbon 51(4):1111-1150.

Stuiver, et.al,1993, Radiocarbon 35(1):137-189, Oeschger,et.al., 1975 Tellus 27:168-192

Mathematics used for calibration scenario

A Simplified Approach to Calibrating C14 Dates

Talma, A. S., Vogel, J. C., 1993, Radiocarbon 35(2):317-322

\section{Beta Analytic Radiocarbon Dating Laboratory}

4985 S.W. 74th Court, Miami, Florida $33155 \cdot$ Tel: (305)667-5167•Fax: (305)663-0964・E-Mail: beta@ radiocarbon.com 


\section{CALIBRATION OF RADIOCARBON AGE TO CALENDAR YEARS}

(Variables: C $13 / \mathrm{C} 12=-8.7: 1 \mathrm{ab} . \mathrm{mult}=1$ )

Laboratory num ber: Beta-324467

Conventional radiocarbon age: $\quad 4080 \pm 30 \mathrm{~B} P$

2 Sigm a calibrated results: Cal BC 2850 to 2810 (Cal BP 4800 to 4760 ) and (95\% probability) Cal BC 2740 to 2720 (Cal BP 4690 to 4680) and Cal BC 2700 to 2570 (C al BP 4640 to 4520 ) and Cal BC 2520 to 2500 (Cal BP 4470 to 4450 )

Intercept data

Intercepts of radiocarbon age with calibration curve:

Ca1 BC 2620 (Ca1 BP 45 70) and Cal BC 2610 (Ca1 BP 4560) and Cal BC 2600 (Cal BP 4550) and $\mathrm{Ca} 1 \mathrm{BC} 2590$ (Cal BP 4540) and Cal BC 2580 (Cal BP 4530)

1 Sigma calibrated results: Cal BC 2830 to 2820 (Cal BP 4780 to 4770 ) and (68\% probability) Cal BC 2660 to 2650 (Cal BP 4610 to 4600 ) and Cal BC 2630 to 2570 (Cal BP 4580 to 4520 )

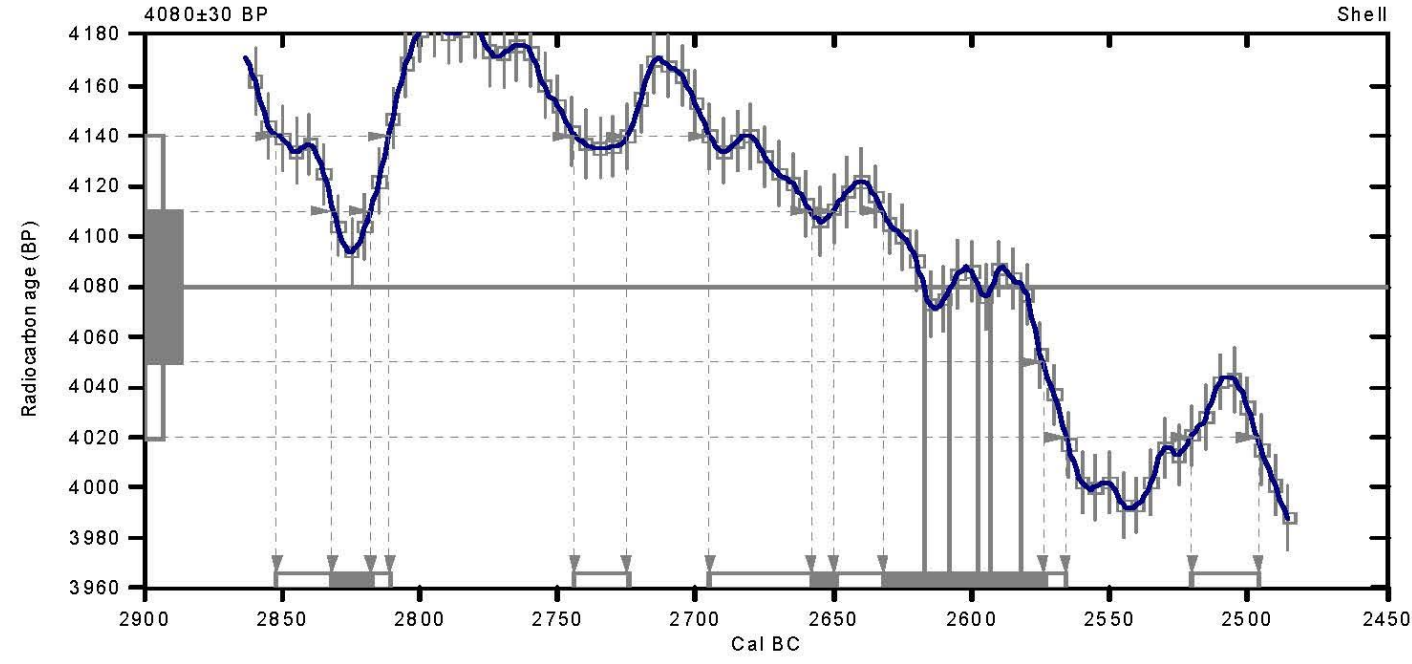

References:

Database used INTCALO 9

References to INTCALO9 database

Heaton, et.al.,2009, Radiocarbon 51(4):1151-1164, Reimer,et.al, 2009, Radiocarbon 51(4):1111-1150 Stuiver, et.al,1993, Radiocarbon 35(1):137-189, Oeschger,et.al.,1975,Tellus 27:168-192

Mathematics used for calibration scenario

A Simplified Approach to Calibrating C14 Dates

Talma, A. S., Vogel, J. C., 1993, Radiocarbon 35(2): 317-322

Beta Analytic Radiocarbon Dating Laboratory

4985 s. W. 74 th Court, Miami, Florida 33155.Tel:(305)667-5167・Fax:(305)663-0964・E-Mail: beta@ radiocarbon.com 


\section{CALIBRATION OF RADIOCARBON AGE TO CALENDAR YEARS}

(Variables: C $13 / \mathrm{C} 12=-19 \cdot 4: 1 \mathrm{ab} . \mathrm{mult}=1$ )

Laboratory num ber: Beta-324468

Conventional radiocarbon age: $3310 \pm 30 \mathrm{BP}$

2 Sigm a calibrated result: Cal BC 1680 to 1510 (Cal BP 3630 to 3460 )

(95\% probability)

Intercept data

Intercept of radiocarbon age

with calibration curve:

Cal BC 1610 (Cal BP 3560)

1 Sigm a calibrated result: Ca1 BC 1620 to 1530 (Ca1 BP 3570 to 3480 )

( $68 \%$ probability)

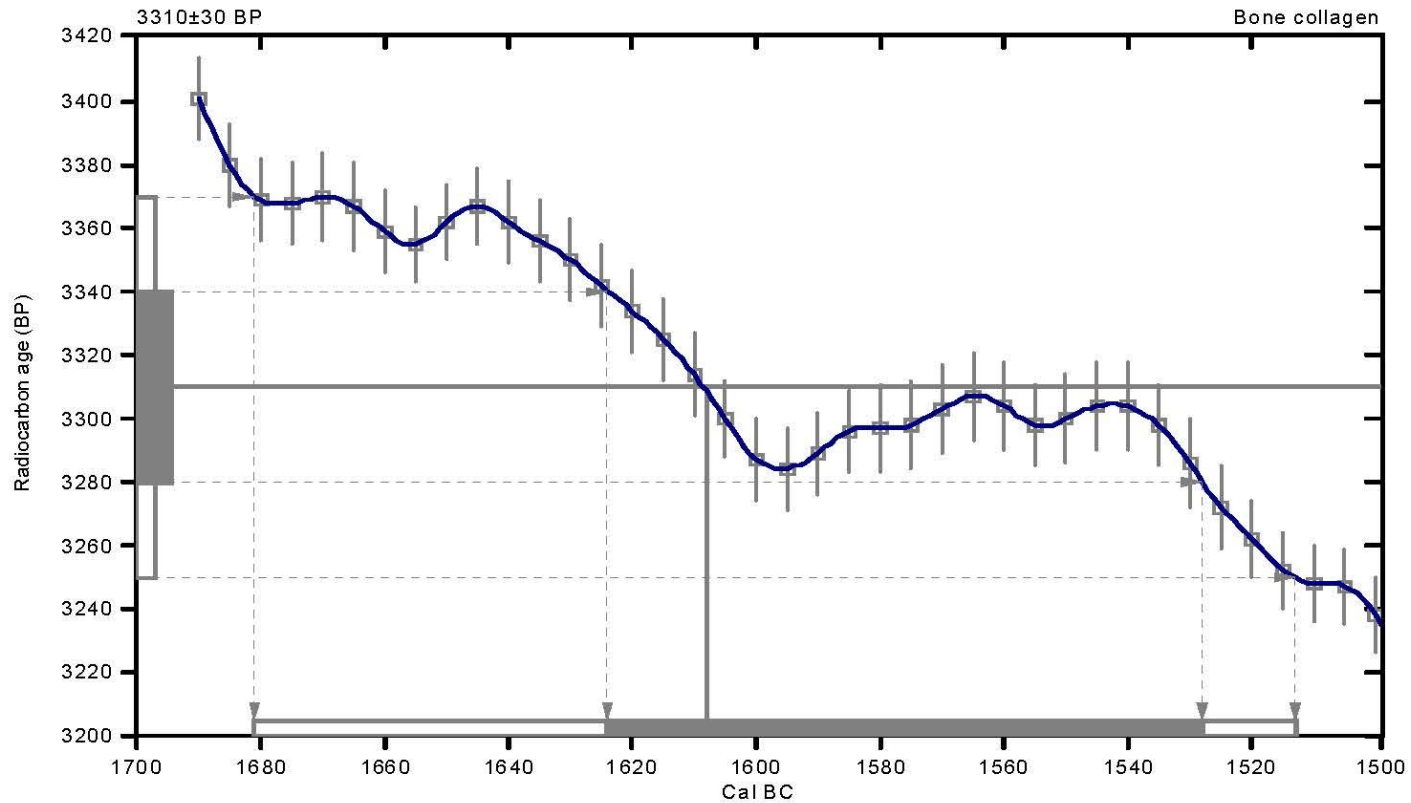

References:

Database used

$$
\text { INTCALO9 }
$$

References to INTCALO9 database

Heato n,et.al.,2009, Radiocarbon 51(4):1151-1164, Reimer,et.al, 2009, Radiocarbon 51(4):1111-1150

Stuiver,etal,1993, Radiocarbon 35(1):137-189, Oeschger,et.al, 1975, Tellus 27:168-192

Math ematics used for calibration scenario

A Simplified Approach to Calibrating C14 Dates

Talma, A. S., Vogel, J. C., 1993, Radiocarbon 35(2):317-322

\section{Beta Analytic Radiocarbon Dating Laboratory}

4985 S.W. 74 th Court, Miami, Florida $33155 \cdot$ Tel: (305)667-5167 - Fax:(305)663-0964 - E-Mail: beta@ 0 radiocarbon.com 


\section{BETA}

Consistent Accuracy..
Beta Analytic Ine.

4985 SW 74 Court

Miami, Florida 33155 USA

Tel: 3056675167

Fax: 3056630964

Beta a radiocarbon.com

www.radiocarbon.com

... Delivered On-time

July 25,2012

Dr. James Abbott

Texas Department of Transportation

Cultural Resource Management

Environmental Affairs Division

125 East 11th Street

Austin, TX 78701

RE: Radiocarbon Dating Results For Samples MM382 106-4 BT-7 130-140 cmbs Sediment Sample, MM382 107-4 TU-3 130-140 cmbs Sediment Sample, MM382 108-4 TU-2 132-141 cmbs Sediment Sample, MM382 109-4 TU-1 133-138 cmbs Sediment Sample, MM382 113-4 Back hoe Trench 7 113118 cmbs Sediment Sample, MM382 114-4 Back hoe Trench 7 182-187 cmbs Sediment Sample

Dear Dr. Abbott:

Enclosed are the radiocarbon dating results for six samples recently sent to us. They each provided plenty of carbon for accurate measurements and all the analyses proceeded normally. As usual, the method of analysis is listed on the report with the results and calibration data is provided where applicable.

As always, no students or intern researchers who would necessarily be distracted with other obligations and priorities were used in the analyses. We analyzed them with the combined attention of our entire professional staff.

If you have specific questions about the analyses, please contact us. We are always available to answer your questions.

Our invoice is enclosed with the mailed report copy. Please, forward it to the appropriate officer or send VISA charge authorization. Thank you. As always, if you have any questions or would like to discuss the results, don't hesitate to contact me.

Sincerely,

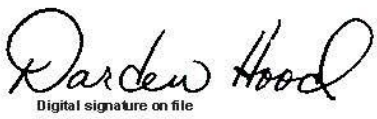




\section{BETA}

BETA ANALYTIC INC.

DR. M.A. TAMERS and MR. D.G. HOOD
4985 S.W. 74 COURT

MIAMI, FLORIDA, USA 33155

PH: 305-667-5167 FAX:305-663-0964

beta@radiocarbon.com

\section{REPORT OF RADIOCARBON DATING ANALYSES}

Dr. James Abbott

Report Date: $7 / 25 / 2012$

Texas Department of Transportation

Material Received: $6 / 22 / 2012$

\begin{tabular}{|c|c|c|c|}
\hline Sample Data & $\begin{array}{l}\text { Measured } \\
\text { Radiocarbon Age }\end{array}$ & $\begin{array}{c}13 \mathrm{C} / 12 \mathrm{C} \\
\text { Ratio }\end{array}$ & $\begin{array}{c}\text { Conventional } \\
\text { Radiocarbon Age }\left(^{*}\right)\end{array}$ \\
\hline $\begin{array}{l}\text { Beta - } 324470 \\
\text { SAMPLE : MM382 106-4 BT } \\
\text { ANAL YSIS : RadiometricPLI } \\
\text { MATERIAL/PRETREATME } \\
2 \text { SIGMA CALIBRATION : }\end{array}$ & $\begin{array}{l}3800+/-30 \mathrm{BP} \\
30-140 \mathrm{cmbs} \text { Sediment Sample } \\
\text { tandard delivery } \\
\text { (organic sediment): acid washe } \\
\text { Cal BC } 2460 \text { to } 2270 \text { (Cal BP } 4\end{array}$ & $\begin{array}{l}-21.3 \mathrm{o} / \mathrm{oo} \\
\mathrm{AND} \mathrm{Cal} \mathrm{B}\end{array}$ & $\begin{array}{c}3860+/-30 \mathrm{BP} \\
(\mathrm{Cal} \mathrm{BP} 4210 \text { to } 4160)\end{array}$ \\
\hline $\begin{array}{l}\text { Beta - } 324471 \\
\text { SAMPLE : MM382 } 107-4 \text { TL } \\
\text { ANALYSIS : RadiometricPLI } \\
\text { MATERIAL/PRETREATME } \\
2 \text { SIGMA CALIBRATION : }\end{array}$ & $\begin{array}{l}\qquad 3520+/-40 \mathrm{BP} \\
30-140 \mathrm{cmbs} \text { Sediment Sample } \\
\text { tandard delivery } \\
\text { (organic sediment): acid washe } \\
\text { Cal BC } 2130 \text { to } 2080 \text { (Cal BP } 4\end{array}$ & $\begin{array}{l}-18.3 \mathrm{o} / \mathrm{oo} \\
\mathrm{AND} \mathrm{Cal} \mathrm{BC}\end{array}$ & (Cal BP 4010 to 3840 ) \\
\hline $\begin{array}{l}\text { Beta - } 324472 \\
\text { SAMPLE : MM382 108-4 TL } \\
\text { ANALYSIS : RadiometricPLI } \\
\text { MATERIAL/PRETREATME } \\
2 \text { SIGMA CALIBRATION : }\end{array}$ & $\begin{array}{l}\qquad 3090+/-30 \mathrm{BP} \\
32-141 \mathrm{cmbs} \text { Sediment Sample } \\
\text { tandard delivery } \\
\text { (organic sediment): acid washe } \\
\text { Cal BC } 1510 \text { to } 1410 \text { (Cal BP } 3\end{array}$ & $-18.6 \mathrm{o} / 00$ & $3190+/-30 \mathrm{BP}$ \\
\hline $\begin{array}{l}\text { Beta - } 324473 \\
\text { SAMPLE : MM382 109-4 TL } \\
\text { ANALYSIS : RadiometricPLI } \\
\text { MATERIAL/PRETREATME } \\
2 \text { SIGMA CALIBRATION : }\end{array}$ & $\begin{array}{l}\qquad 3120+/-40 \mathrm{BP} \\
33-138 \mathrm{cmbs} \text { Sediment Sample } \\
\text { tandard delivery } \\
\text { (organic sediment): acid washe } \\
\text { Cal BC } 1610 \text { to } 1430 \text { (Cal BP } 3\end{array}$ & $-17.9 \mathrm{o} / 00$ & $3240+/-40 \mathrm{BP}$ \\
\hline
\end{tabular}

Dates are reported as RCYEP (radiocarbon years before present, "present" = AD 1950). By international convention, the modern reference standard was $95 \%$ the $14 \mathrm{C}$ activity of the National Institute of Standards and Technology (NIST) Oxalic Acid (SRM 4990C) and calculated using the Libby $14 \mathrm{C}$ half-life ( 5568 years). Quoted errors represent 1 relative standard deviation statistics $(68 \%$ probability) counting errors based on the combined measurements of the sample, background, and modem reference standards. Measured $13 \mathrm{C} / 12 \mathrm{C}$ ratios (delta 13C) were calculated relative to the PDB-1 standard.
The Conventional Radiocarbon Age represents the Measured Radiocarbon Age corrected for isotopic fractionation, calculated using the delta $13 \mathrm{C}$. On rare occasion where the Conventional Radiocarbon Age was calculated using an assumed delta $13 \mathrm{C}$. the ratio and the Conventional Radiocarbon Age will be followed by $" * n$, The Conventional Radiocarbon Age is not calendar calibrated When available, the Calendar Calibrated result is calculated from the Conventional Radiocarbon Age and is listed as the "Two Sigma Calibrated Result" for each sample. 


\section{BETR BETA ANALYTIC INC.}

\section{REPORT OF RADIOCARBON DATING ANALYSES}

Dr. James Abbott

\begin{tabular}{|c|c|c|}
\hline Sample Data & $\begin{array}{c}\text { Measured } \\
\text { Radiocarbon Age }\end{array}$ & $\begin{array}{c}13 \mathrm{C} / 12 \mathrm{C} \\
\text { Ratio }\end{array}$ \\
\hline $\begin{array}{l}\text { Beta - } 324474 \\
\text { SAMPLE : MM382 } 1134 \text { Back ho } \\
\text { ANALYSIS : RadiometricPLUS-St } \\
\text { MATERIAL/PRETREATMENT : } \\
2 \text { SIGMA CALIBRATION : }\end{array}$ & $\begin{array}{l}3230+/-30 \mathrm{BP} \\
\text { Trench } 7113-118 \mathrm{cmbs} \text { Sediment Sample } \\
\text { tandard delivery } \\
\text { (organic sediment): acid washes } \\
\text { Cal BC } 1680 \text { to } 1520 \text { (Cal BP } 3640 \text { to } 3470 \text { ) }\end{array}$ & $-19.7 \mathrm{o} / 00$ \\
\hline $\begin{array}{l}\text { Beta - } 324475 \\
\text { SAMPLE : MM382 114-4 Back ho } \\
\text { ANALYSIS : RadiometricPLUS-St } \\
\text { MATERIAL/PRETREATMENT : } \\
2 \text { SIGMA CALIBRATION : }\end{array}$ & $\begin{array}{l}5020+/-40 \mathrm{BP} \\
\text { Trench } 7182-187 \mathrm{cmbs} \text { Sediment Sample } \\
\text { andard delivery } \\
\text { (organic sediment): acid washes } \\
\text { Cal BC } 3970 \text { to } 3790 \text { (Cal BP } 5920 \text { to } 5740 \text { ) }\end{array}$ & $-19.9 \mathrm{o} / 00$ \\
\hline
\end{tabular}

Report Date: $7 / 25 / 2012$
Dates are reported as RCYEP (radiocarbon years before present, "present" = AD 1950). By international convention, the modern reference standard was $95 \%$ the $14 \mathrm{C}$ activity of the National Institute d represent 1 relative standard deviation statistics (68\% probability) counting errors based on the combined measurements of the sample, counting enced background, and modern reference standards. Measured $13 \mathrm{C} / 12 \mathrm{C}$ ratios (delta 13C) were calculated relative to the PDB-1 standard.
The Conventional Radiocarbon Age represents the Measured Radiocarbon Age corrected for isotopic fractionation, calculated using the delta $13 \mathrm{C}$. On rare occasion where the Conventional Radiocarbon Age was calculated using an assumed delta $13 \mathrm{C}$ the ratio and the Conventional Radiocarbon Age will be followed by "*n" The Conventional Radiocarbon Age is not calendar calibrated. from from the Conventional Radiocarbon Age and is listed as the "Two Sigma Calibrated Result" for each sample. 


\section{CALIBRATION OF RADIOCARBON AGE TO CALENDAR YEARS}

(Variables: C $13 / \mathrm{C} 12=-21.3: 1 \mathrm{ab} \cdot \mathrm{mult}=1$ )

Labor atory num ber: Beta-324470

Conventional radiocarbon age: $3860 \pm 30 \mathrm{BP}$

2 Sigm a calibrated results: Cal BC 2460 to 2270 (Cal BP 4410 to 4220 ) and (95\% probability) Cal BC 2260 to 2200 (Cal B P 4210 to 4160)

Intercept data

Intercepts of radiocarbon age with calibration curve:

Cal BC 2330 (Cal BP 4280) and Cal BC 2320 (Cal BP 4270) and

Cal BC 2300 (Cal BP 4250)

$1 \mathrm{~S}$ ig ma calibrated results: Cal BC 2430 to 2420 (Cal BP 4380 to 4370 ) and ( $68 \%$ probability) Cal BC 2400 to 2380 (Ca1 BP 4350 to 4330 ) and Cal BC 2350 to 2290 (Cal BP 4300 to 4240 )

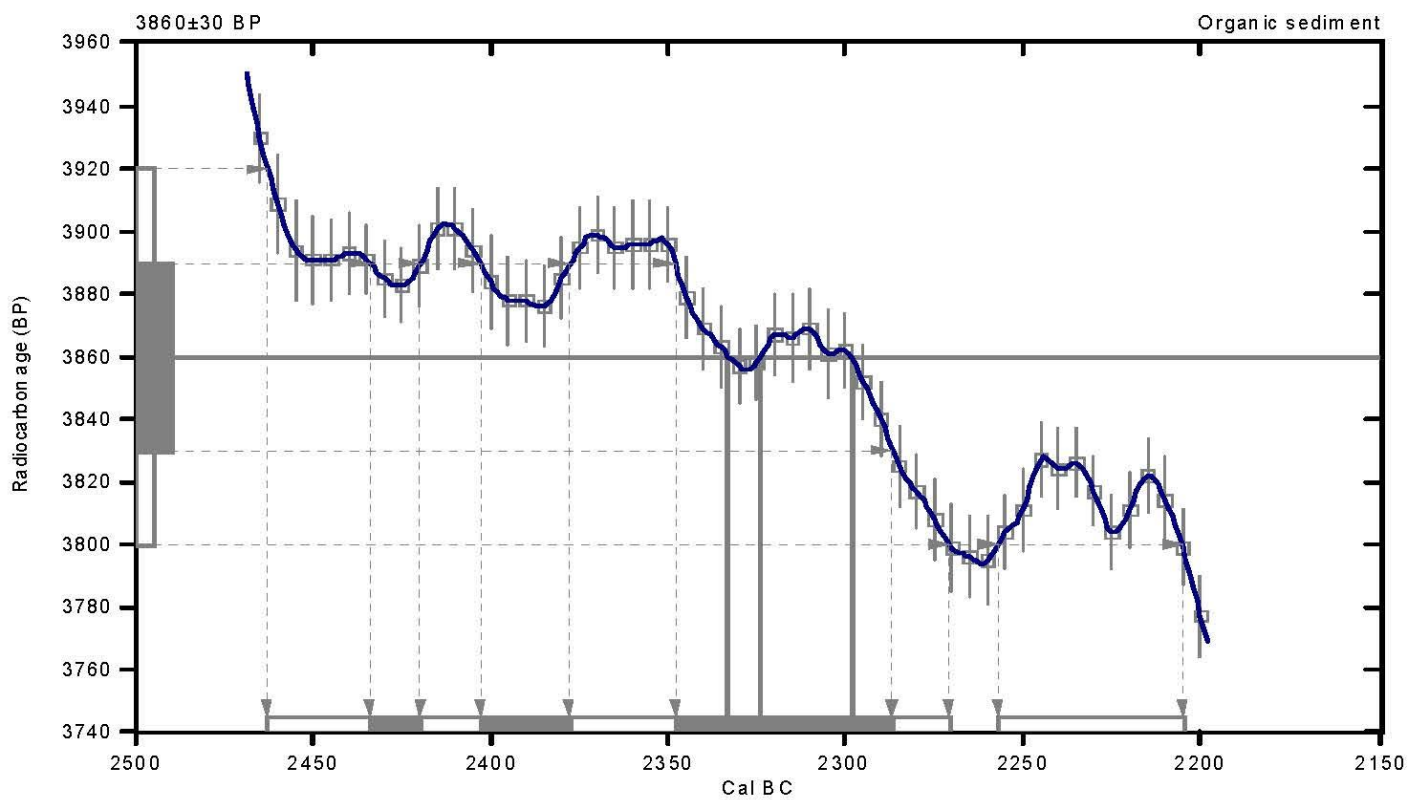

References:

Database used

INTCALO9

References to INTCALO9 database

Heato n, et.al.2009, Radiocarbon 51(4):1151-1164, Reimer,et.al, 2009, Radiocarbon 51(4):1111-1150, Stuiver, et.al,1993, Radiocarbon 35(1):137-189, Oeschger,et.al., 1975, Tellus 27:168-192

Mathematics used for calib ration scenario

A Simplified Approach to Calibrating C14 Dates

Talma, A. S., Vogel, J. C., 1993, Radiocarbon 35(2):317-322

\section{Beta Analytic Radiocarbon Dating Laboratory}




\section{CALIBRATION OF RADIOCARBON AGE TO CALENDAR YEARS}

(Variables: C $13 / \mathrm{C} 12=-18.3: 1 \mathrm{ab} . \mathrm{mult}=1$ )

Laboratory number: Beta-324471

Conventional radiocarbon age: $3630 \pm 40 \mathrm{BP}$

2 Sigm a calibrated results: Cal BC 2130 to 2080 (Cal BP 4080 to 4030 ) and

(95\% probability) Cal BC 2060 to 1890 (Cal BP 4010 to 3840)

Intercept data

Intercepts of radiocarb on age

with calibration curve: Cal BC 2010 (Cal BP 3960) and

Cal BC 2000 (Cal BP 3950) and

Cal BC 1980 (Cal BP 3930 )

$1 \mathrm{~S}$ ig m a calibrated result: Cal BC 2030 to 1940 (Cal BP 3980 to 3890 ) ( $68 \%$ probability)

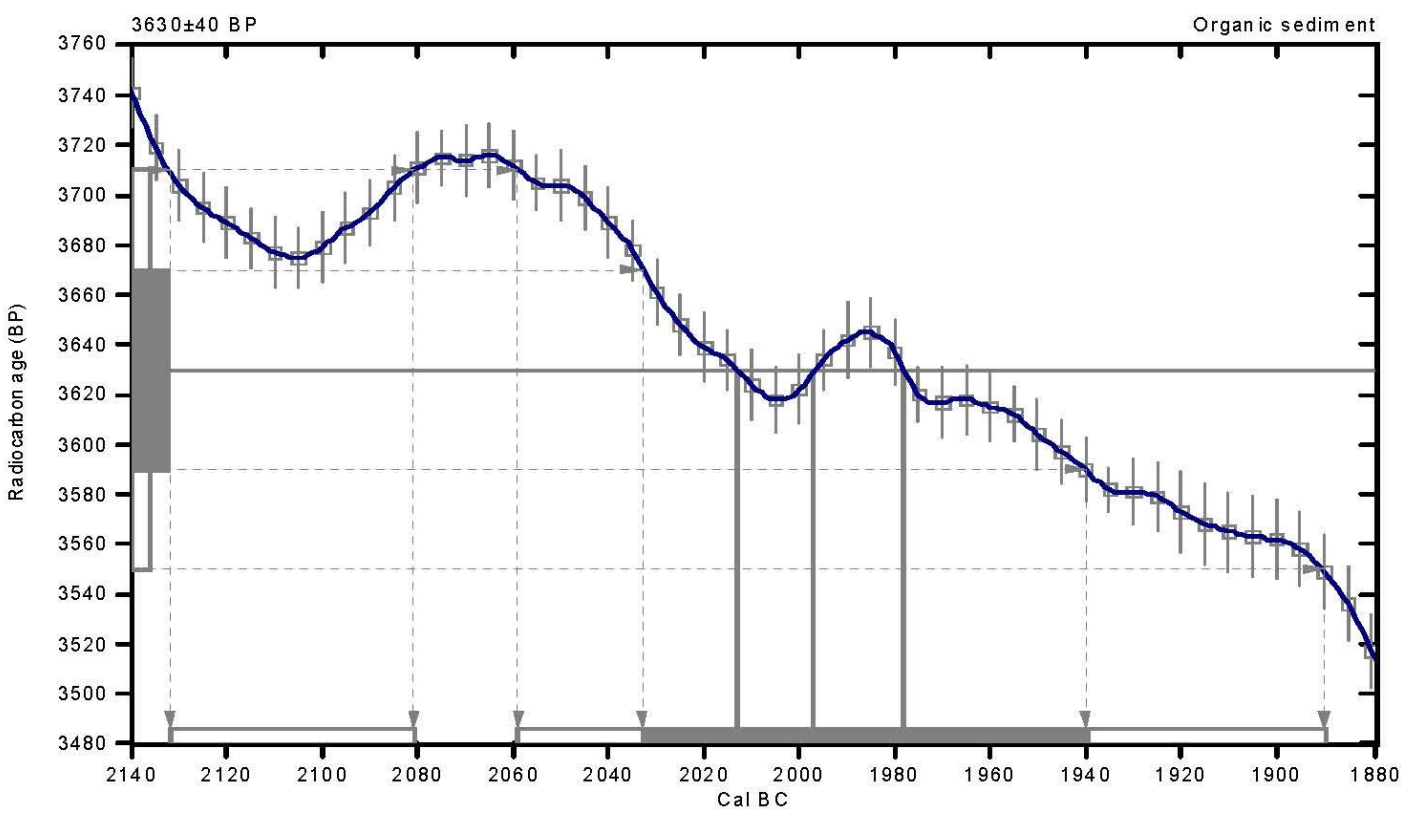

References:

Database used

INTCALO9

References to INTCALO9 database

Heato net.al..2009, Radio carbon 51(4):1151-1164, Reimer,et.al, 2009, Radiocarbon 51(4):1111-1150,

Stuiver, et.al,1993, Radiocarbon 35(1):137-189, Oeschger, et.al., 1975, Tellus 27:168-192

Mathematics used for calibration scenario

A Simplified Approach to Calibrating C 14 Dates

Talma, A. S., Vogel, J. C., 1993, Radiocarbon 35(2):317-322

\section{Beta Analytic Radiocarbon Dating Laboratory}

4985 S.W.74th Court, Miami, Florida 33155 -Tel: (305)667-5167・Fax:(305)663-0964・E-Mail: beta@ radiocarbon.com 


\section{CALIBRATION OF RADIOCARBON AGE TO CALENDAR YEARS}

(Variables: C 13/C 12=-18.6:1ab. mult $=1$ )

Laboratory number: Beta-324472

Conventional radiocarbon age: $3190 \pm 30 \mathrm{BP}$

2 Sigm a calibrated result: Cal BC 1510 to 1410 (Cal BP 3460 to 3360) ( $95 \%$ probability)

Intercept data

Intercept of radiocarbon age

with calibration curve: Cal BC 1450 (Ca1 BP 3400)

1 Sigma calibrated result: Cal BC 1500 to 1430 (Cal BP 3440 to 3380 )

( $68 \%$ probability)

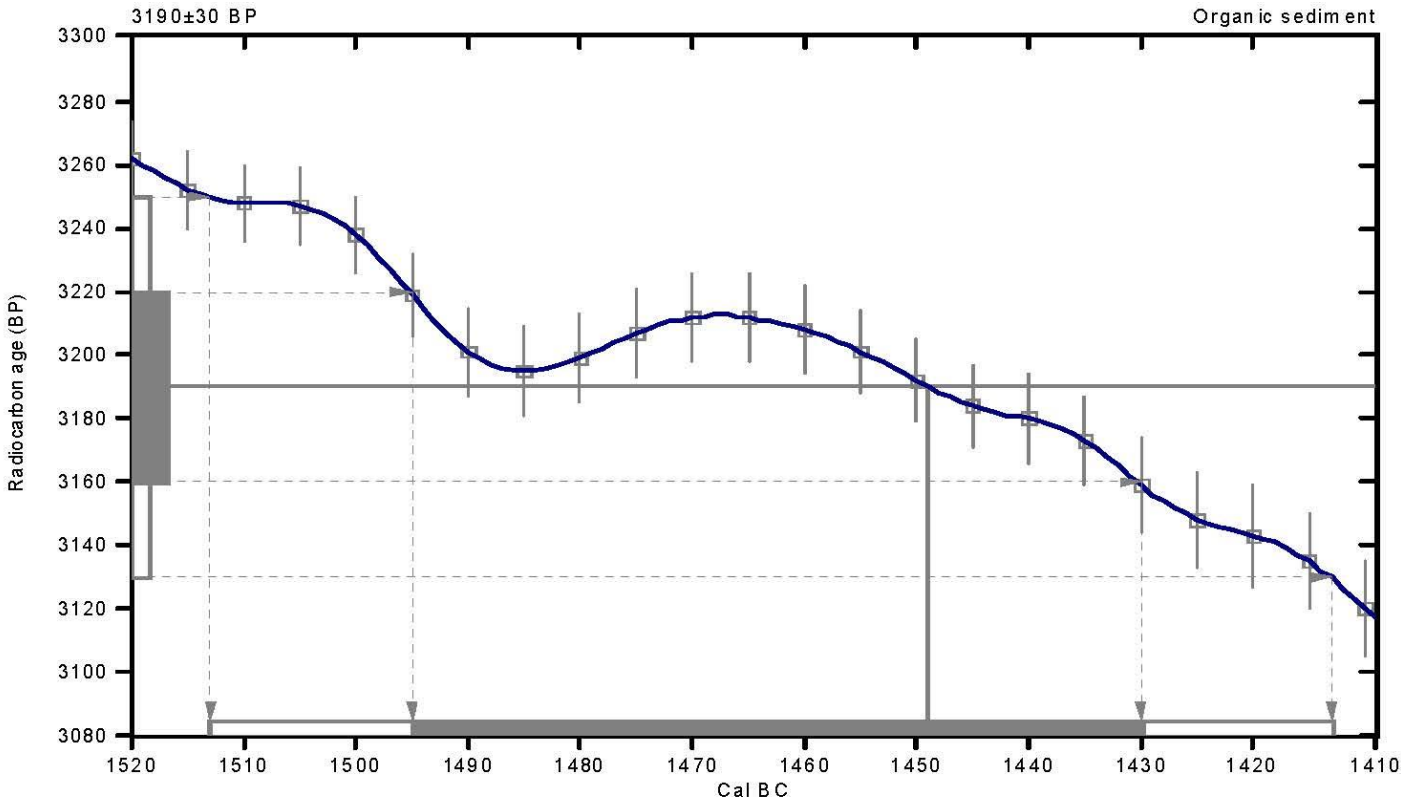

References:

Database used

INTCALO9

References to INTCALO9 database

Hea to n,et.al..2009, Radiocarbon 51(4):1151-1164, Reimer,et.al, 2009, Radiocarbon 51(4):1111-1150,

Stuiver, et.al,1993, Radiocarbon 35(1):137-189, Oeschger, et.al.,1975, Tellus 27:168-192

Mathematics used for calib ration scenario

A Simplified Approach to Calibrating C14 Dates

Talma, A. S., Vogel, J. C., 1993, Radiocarbon 35(2):317-322

\section{Beta Analytic Radiocarbon Dating Laboratory}

4985 S.W. 74th Court, Miami, Florida $33155 \cdot$ Tel: (305)667-5167• Fax:(305)663-0964・E-Mail: beta@ radiocarbon.com 


\section{CALIBRATION OF RADIOCARBON AGE TO CALENDAR YEARS}

(Variables: C 13/C 12=-17.9:1ab. mult $=1$ )

Laboratory number: Beta-324473

Conventional radiocarbon age: $3240 \pm 40 \mathrm{BP}$

2 Sigm a calibrated result: Cal BC 1610 to 1430 (Cal BP 3560 to 3380) (95\% probability)

Intercept data

Intercept of radioc arbon age

with calibration curve: Cal BC 1500 (Cal BP 3450)

$1 \mathrm{~S}$ igma calibrated results: Cal BC 1530 to 1490 (Cal BP 3480 to 3440 ) and

(68\% probability) Cal BC 1480 to 1450 (Cal BP 3430 to 3400 )

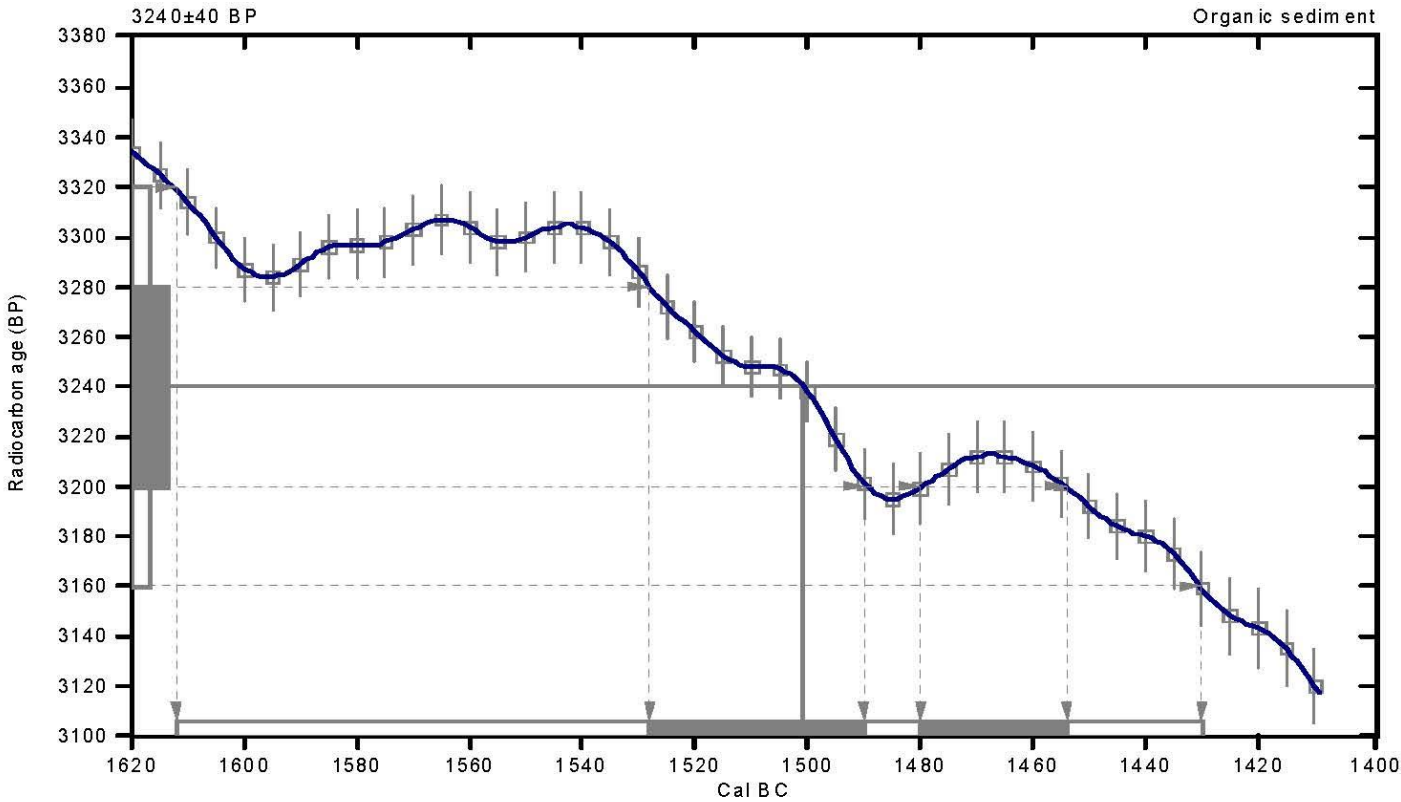

References:

Database used

INTCALO9

References to INTCALO9 database

Heato net.al.,2009, Radio carbon 51(4):1151-1164, Reimer,et.al, 2009, Radiocarbon 51(4):1111-1150,

Stuiver, et.al,1993, Radiocarbon 35(1):137-189, Oeschger, et.al., 1975, Tellus 27:168-192

Mathematics used for calibration scenario

A Simplified A pproach to Calibrating C14 Dates

Talma, A. S., Vogel, J. C., 1993, Radiocarbon 35(2):317-322

\section{Beta Analytic Radiocarbon Dating Laboratory}

4985. S.W.74th Court, Miami, Florida 33155・Tel:(305)667-5167・Fax:(305)663-0964・E-Mail: beta@ radiocarbon.com 


\section{CALIBRATION OF RADIOCARBON AGE TO CALENDAR YEARS}

(Variables: C $13 / \mathrm{C} 12=-19.7: 1 \mathrm{ab} \cdot \mathrm{mult}=1$ )

Laboratory n umber: Beta-324474

Conventional radiocarbon age: $3320 \pm 30 \mathrm{BP}$

2 Sigm a calibrated result: Cal BC 1680 to 1520 (Cal BP 3640 to 3470 ) ( $95 \%$ probability)

Intercept data

Intercept of radiocarbon age

with calibration curve: Cal BC 1610 (Cal BP 3560)

$1 \mathrm{~S}$ igma calibrated results: Cal BC 1630 to 1600 (Cal BP 3580 to 3550 ) and

(68\% probability) Cal BC 1590 to 1530 (Cal BP 3540 to 3480 )

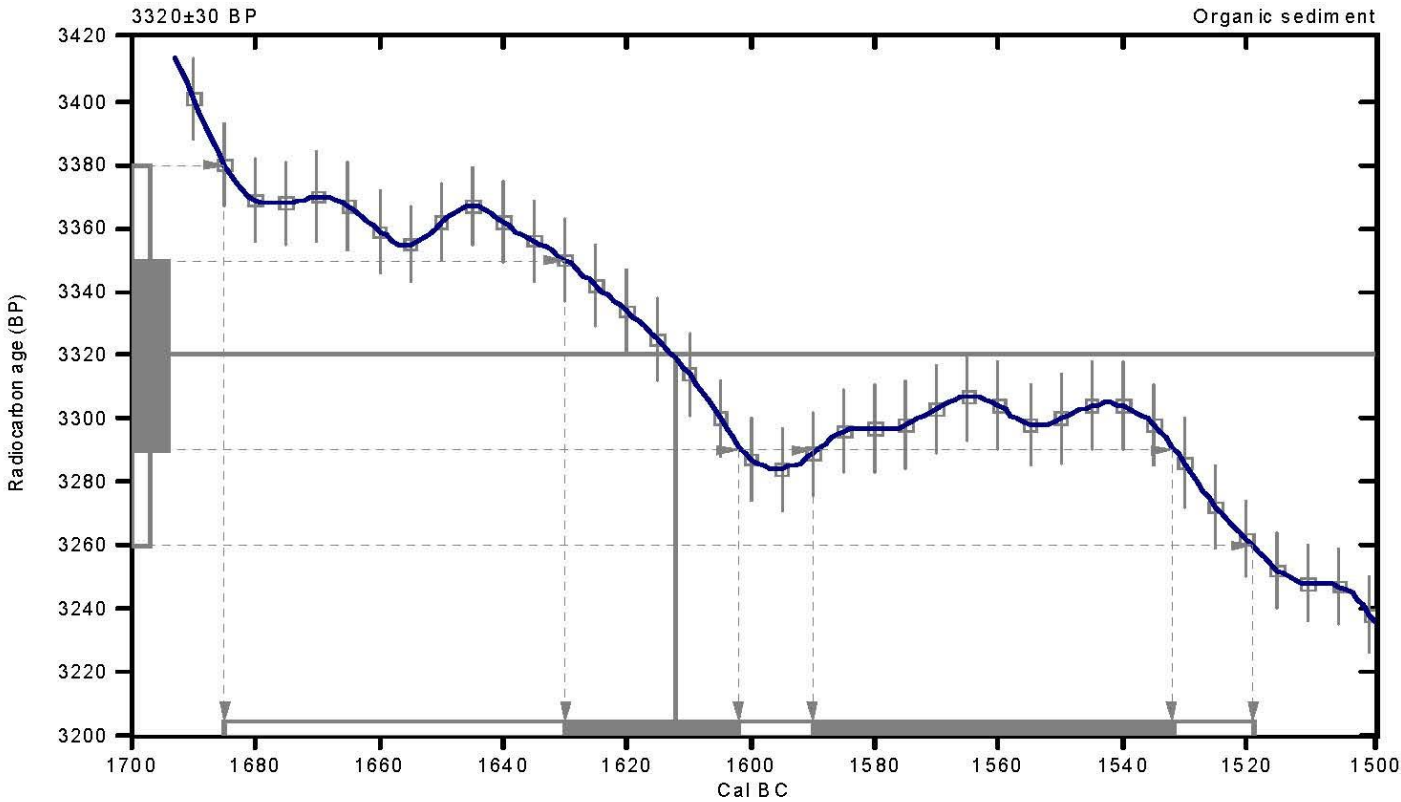

References:

Database used

INTCALO9

References to INTCALO9 database

Hea to n,et.al..2009, Radiocarbon 51(4):1151-1164, Reimer,et.al, 2009, Radiocarbon 51(4):1111-1150,

Stuiver, et.al,1993, Radiocarbon 35(1):137-189, Oeschger, et.al.,1975, Tellus 27:168-192

Mathematics used for calib ration scenario

A Simplified Approach to Calibrating C14 Dates

Talma, A. S., Vogel, J. C., 1993, Radiocarbon 35(2):317-322

\section{Beta Analytic Radiocarbon Dating Laboratory}

4985 S.W. 74th Court, Miami, Florida $33155 \cdot$ Tel: (305)667-5167• Fax:(305)663-0964・E-Mail: beta@ radiocarbon.com 


\section{CALIBRATION OF RADIOCARBON AGE TO CALENDAR YEARS}

(Variables: C 13/C 12=-19.9:1ab. mult=1)

Laboratory number: Beta-324475

Conventional radioc arbon age: $\quad 5100 \pm 40 \mathrm{BP}$

2 Sigm a calibrated result: Cal BC 3970 to 3790 (Cal BP 5920 to 5740) (95\% probability)

Intercept data

Intercept of radioc arbon age

with calibration curve: Cal BC 3950 (Cal BP 5900)

$1 \mathrm{~S}$ igma calibrated results: Cal BC 3960 to 3930 (Cal BP 5910 to 5880 ) and

(68\% probability) Cal BC 3870 to 3800 (Cal BP 5820 to 5760 )

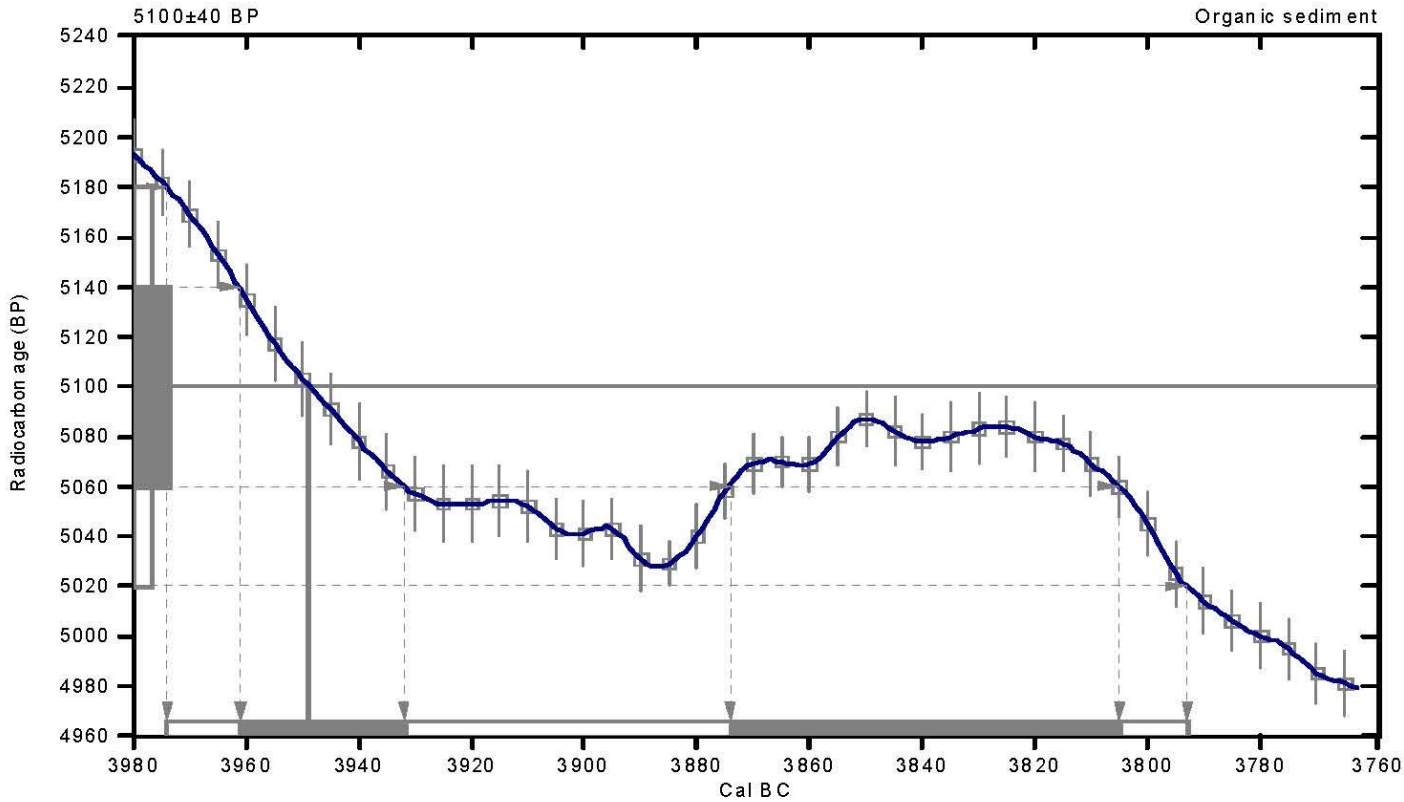

References:

Database used

INTCALO9

References to INTCALO9 database

Heato net.al..2009, Radio carbon 51(4):1151-1164, Reimer,et.al, 2009, Radiocarbon 51(4):1111-1150,

Stuiver, et.al,1993, Radiocarbon 35(1):137-189, Oeschger, et.al., 1975, Tellus 27:168-192

Mathematics used for calibration scenario

A Simplified A pproach to Calibrating C14 Dates

Talma, A. S., Vogel, J. C., 1993, Radiocarbon 35(2):317-322

\section{Beta Analytic Radiocarbon Dating Laboratory}

4985 S.W.74th Court, Miami, Florida 33155 -Tel: (305)667-5167・Fax:(305)663-0964・E-Mail: beta@ radiocarbon.com 
This page intentionally left blank. 


\title{
APPENDIX B: STARCH ANALYSIS OF SAMPLES FROM 41 MM382 IN MILAM COUNTY, TEXAS
}

Prepared for:

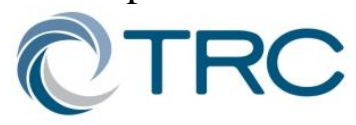

TRC Environmental Corporation 505 East Huntland Drive, Suite 250

Austin, Texas 78752

\begin{abstract}
Prepared by:
Linda Perry, Ph.D.

Executive Director
\end{abstract}

The Foundation for Archeobotanical Research in Microfossils

P.O. Box 37

Fairfax, VA 22038 
This page intentionally left blank. 
STARCH ANALYSIS OF SAMPLES FROM 41 MM382 IN MILAM COUNTY, TEXAS

Linda Perry, Ph.D.

\section{B.1 INTRODUCTION TO STARCH GRAIN ANALYSES}

Archaeobotanical investigators are constantly seeking new methods by which previously unobtainable data can be recovered. Among archeologists who work in regions characterized by the poor preservation of organic remains, the analyses of starch granules have proven particularly useful in accessing the residues of starchy root and tuber crops that have previously been invisible in the archeological record (Bryant 2003; Coil et al. 2003; Fullagar et al. 1998; Hall et al. 1989; Iriarté et al. 2004; Loy et al. 1992; Pearsall et al. 2004; Perry 2001, 2002, 2004, 2005, 2007; Perry and Quigg 2011a, 2011b; Perry et al. 2006, 2007, 2010; Piperno and Holst 1998; Piperno et al. 2000). These residues have proven to be tenacious survivors in harsh climates, and their preservation on the surfaces of lithic tools that were used in the processing of starch-bearing plants occurs consistently in archaeobotanical investigations (Iriarté et al. 2004; Pearsall et al. 2004; Perry 2001, 2002, 2004, 2005, 2007, 2010; Perry and Quigg 2011a, 2011b; Perry et al. 2006, 2007; Piperno and Holst 1998; Piperno et al. 2000).

Investigations of the starchy remains of plant foods on the surfaces of archeological lithic tools began with simple analyses using chemical reagents that identified the residues in question as plant-derived storage starch (Bruier 1976) rather than animal tissue. Within the last fifteen years, however, archeologists have been successfully employing morphological criteria to identify plant taxa. The methods are almost identical to those used in the analysis of phytolith microfossils.
Just as different plants produce characteristically shaped leaves, flowers, and seeds, different genera and species make starch grains that are distinctive to and diagnostic for each taxon. The anatomical features that distinguish the starch of one species of plant from another have been noted by botanists (e.g., Denniston 1904; MacMasters 1964; Reichert 1913), and their methods have been expanded by archaeobotanists who are now able even to distinguish wild from domesticated species in some plant families (Iriarté et al. 2004; Pearsall et al. 2004; Perry 2001, 2002, 2004; Piperno et al. 2000). Basic physical features that are comparable between modern reference specimens and archeological samples can be viewed using a light microscope and include gross morphological features such as shape and faceting, the location of and appearance of the hilum, and presence and patterning of lamellae (Iriarté et al. 2004; Loy 1994; Pearsall 2004; Perry 2004; Piperno and Holst 1998; Piperno et al. 2000). Fissuring and other internal patterning have also proven to be useful criteria for identification. The successful identification of starch granules relies upon the viewing of each granule in three dimensions to gain an accurate assessment of its morphological features.

Because starch granules differ morphologically between plants, their distinctive characteristics can often allow identification to the level of genus or species in archeological samples (e.g., Iriarté et al. 2004; Pearsall et al. 2004; Perry 2001, 2002, 2004, 2005, 2007; Perry et al. 2006, 2007; Piperno and Holst 1998; Piperno et al. 2000). The method has proven particularly useful in identifying the remains of plant tissues that would not usually be preserved as macroremains, such as the remnants of root and tuber crops (Bryant 2003; Coil et al. 2003; Fullagar et al. 1998; Hall et al. 1989; Iriarté et al. 2004; Loy et al. 1992; Pearsall et al. 2004; Perry 2001, 2002, 2004, 2005; Piperno and Holst 1998; Piperno et al. 2000). This role of starch analysis as a tool for revealing the significance of plant foods in the archaeobotanical record also adds to our 
understanding of the pre-contact significance of starchy seed crops like maize (Zea mays).

In a citation of preliminary results from an ongoing study, the archeological remains of maize starch have been extracted from 2000-year old obsidian artifacts from the Honduran site of Copán (Haslam 2003 , 2004). The starchy residues of maize were also successfully recovered and identified from a migmatite milling stone from Cueva de los Corrales 1 in Argentina (Babot and Apella 2003). In this case, the grinding stone was found to have multiple purposes, including the grinding of burned bone, presumable for a nonfood purpose. Starch analyses of ground stone artifacts from Real Alto have supported previously published phytolith studies that indicate the great antiquity of maize in Ecuador, and its role in subsistence during the Formative period (Pearsall et al. 2004). Seventeen examined artifacts from Real Alto yielded concentrations of maize starch granules ranging from one to more than ten granules per sampled tool. Other Neotropical studies have resulted in the recovery of more complex assemblages of starches.

Archeologists have recovered starch granules from maize, beans (Phaseolus sp.), and Canna from the Los Ajos mound complex in Uruguay (Iriarté et al. 2004). Maize starch granules were reported from three ground stone tools including one mano and two milling stone bases. Concentrations of maize starches ranged from two to eleven granules on tools from contexts dating from 3600 years before present to about 500 years before present (Iriarté et al. 2004: supplementary information). The starch data were combined with phytolith evidence and, together, these results introduce compelling evidence for the early development of a mixed subsistence economy in this region of South America. In other regions of the Neotropics, starch analysis has been an essential tool in defining similar subsistence patterns that included the exploitation of root and tuberous food plants.
Starch granules of maize, manioc (Manihot esculenta), both wild type and domesticated yams (Dioscorea spp.), and arrowroot (Maranta arundinacea) have been recovered from edge ground cobbles and grinding stone bases collected from the Aguadulce rockshelter as well as the sites of Monagrillo, La Mula, and Cerro Juan Diaz in Panama (Piperno and Holst 1998; Piperno et al. 2000). Edge ground cobbles are characterized by faceting that is hypothesized to have resulted from the processing of root crops against larger grinding stone bases (Ranere 1975), and the analyses of the residual remains of plant tissues supports this hypothesis. However, the use of the milling stones does appear to have been more complex than previously believed. Maize remains were recovered from all twelve artifacts that bore starch (Piperno et al. 2000). The numbers of starch granules of maize per artifact ranged from one to twenty-five per artifact. Two starch granules of arrowroot occurred on a single artifact, manioc starch granules were recovered from three artifacts (one, five, and eight granules), and yam starch granules were found on the surfaces of three of the artifacts (two, three, and sixteen granules) (Piperno et al. 2000). These investigations resulted in the recovery of the oldest evidence for root and tuber crop cultivation in the Neotropics, with radiocarbon dates spanning from 5,000 to 7,000 years before present.

Starch granules of maize, yams, and arrowroot have also been recovered from twelve flake and three ground stone tools collected from Pozo Azul Norte 1 and Los Mangos del Parguaza in Venezuela (Perry 2001, 2002, 2004, 2005). These sites date from the middle first century A.D. to contact. As in the above-cited set of studies, maize remains were recovered from every examined artifact and ranged in number from two to fifty-one per artifact. Additionally, four granules of yam starch were recovered from two flake tools, four flake tools yielded four granules of guapo (Myrosma sp.) starch, and seven starch granules from arrowroot were collected from five tools, one of which was a 
ground stone artifact. These findings were significant in that five of the examined artifacts were chosen for study due to their hypothetical function as microlithic grater flakes from a manioc specific grater board. The evidence indicated a more complex function of these tools that did not include the processing of manioc.

More recent investigations have led to the recovery of direct evidence for contact between the highland Peruvian Andes and the lowland tropical forest to the east (Perry et al. 2006). This contact and interaction had been a significant component of Andean theory for decades, but direct evidence had been elusive until starch microfossils of arrowroot were collected from both sediment samples and lithic tools at the mid-elevation site of Waynuna (Perry et al. 2006). Further, the discovery and cataloging of a microfossil will allow for the recovery and understanding of the origins and subsequent dispersals of chili peppers (Perry et al. 2007), plants whose histories are poorly understood due to the lack of preservation of macroremains in the archaeobotanical record. Remains of these plants have been successfully recovered throughout the Americas from ceramic sherds, lithic tools, and sediment samples dating from 6250 B.P. to European contact.

\section{B.2 UNDERSTANDING THE RELATIONSHIP BETWEEN RESIDUES AND ARTIFACTS}

Early work on starch remains from Panamanian sites used stepwise analysis to support the direct association between starchy residues on tools and the tools' use (Piperno et al. 2000). These studies demonstrated that starch grains were not present in sediments adhering to stone tools or on unused parts of the lithics, but they did occur in the cracks and crevices of the tools on used surfaces, thus indicating that the residues were the result of the tools' use and not environmental contamination. Similar experiments have been undertaken independently by other researchers, and the results were equivalent.

In a study of obsidian artifacts recovered from an open air site in Papua New Guinea, the frequency of starch granules recovered from stone artifacts was compared to that present in the soil matrix immediate to the tool (Barton et al. 1998). The frequency of starch granules was found to be much higher on used artifacts than in the surrounding soil. Thus, the conclusion was drawn that the tools were not contaminated by environmental starch sources. Further, use-wear analyses were used in combination with the soil and starch analyses to assess the degree of association of starchy residues with the used surfaces of tools (Barton et al. 1998). The researchers found that, indeed, the occurrence of starch granules was highly correlated with obsidian tools that bore use-wear and was not correlated with unused tools.

In a study of starch residues occurring on stone pounding tools from the Jimmium site in northcentral Australia, the starch forms in soil samples were compared to those extracted from the artifacts (Atchison and Fullagar 1998). It was found that, although starch granules did occur in the soil matrices surrounding the tools, they were of different size and shape than those present on the pounding stones, and, therefore, are probably not from the same plant source. This result was interpreted as evidence that the tools had not been contaminated by soil-borne starches.

Another method for assessing whether or not starch residues are culturally deposited involves the analysis of control samples from noncultural contexts surrounding a site. If different types of starches, or different concentrations of starches, or no plant residue whatsoever are recovered from the control samples than are recovered from the artifacts undergoing testing, then one can be more secure that the residues are the remains of prehistoric food processing (Brieur 1976). 
In addition to the study of association of microfossils with tool use, experimentation with processing methods has also been undertaken. In Argentina, a researcher replicated ancient Andean methods of food processing and found that each different process resulted in diagnostic damage to starch granules in plant tissues including potato tubers (Solanum tuberosum) and quinoa seeds (Chenopodium spp.) (Babot 2003). Modern plant materials were subjected to freeze-drying, dehydration, roasting, charring, desaponification (a process particular to the preparation of quinoa), and grinding. It was found that fragments of starches that would probably otherwise be identified as unknowns or non-starches are actually damaged starches. Further, with careful analysis, researchers can link damage patterns with processing techniques (Babot 2003). Experimentation with various cooking techniques has resulted in similar conclusions: cooked starches are identifiable as such, and different cooking techniques yield different patterns of damage (Henry et al. 2009).

Recent work at the Pipeline, Pavilion, and Corral sites in Texas have demonstrated the utility of starch grain analysis in understanding the function of burned rocks in archeological contexts (Perry 2010; Perry and Quigg 2011a). Here, the analysis of burned rocks yielded starch grains that bore clear damage from boiling and secured the function of many burned rocks as boiling stones used for the cooking of wildrye. The analysis of other artifacts from the sites yielded wildrye starches bearing damage from grinding, thus indicating that the grain was probably milled into flour prior to cooking (Perry 2010; Perry and Quigg 2011a).

Archaeobotanists have focused their energies upon honing their methods toward the effective recovery of and identification of residual starch granules to understand plant use and processing. Studies have resulted in an impressive assemblage of various suites of starchy food plants, both wild and domesticated, raw and cooked. At this juncture in time, more studies are being undertaken and starch remains are being successfully recovered. What we now lack are baseline data as to how and why different plant materials may or may not adhere to stone tools. Thus, we are not yet able to understand issues such as intensity of use based upon numbers of recovered grains, or the history of a tool based upon the numbers of species of plants recovered from its surface. Linda Perry has obtained funding and will be performing experiments over the next year in the hopes of gaining an understanding of these issues.

\section{B.3 METHODS}

Ten samples were selected for preliminary analysis, and all were burned rocks. All artifacts were collected and bagged separately without washing. Washing is a traditional step in the collection and curation of artifacts, but it will remove some of the residues that are of interest to archeologists.

All artifacts were placed in clean, metal beakers and were covered with filtered water. The beakers were then set aside for ten minutes to soak in the hope that this step would loosen the microfossils and allow for a better extraction. At this point, the beakers were placed in a sonic bath for ten minutes to shake the microfossils loose from the artifacts. The artifacts were removed from the beakers and the surfaces were rinsed with filtered water that was collected in the same effluent vessel.

The effluent from the cleaning was allowed to settle overnight, then the settled material was centrifuged for ten minutes at 1,000 RPM to pellet out the solids. The solid materials were then subject to a heavy liquid flotation using cesium chloride $(\mathrm{CsCl})$ at a density of $1.8 \mathrm{~g} / \mathrm{cm}^{3}$ to separate the starch grains from the sediment matrix.

The material collected from the flotation was rinsed and centrifuged three times with filtered water to ensure that the $\mathrm{CsCl}$ was completely removed from the solution. At this point, the pellet from the final centrifugation was placed on a clean glass slide with a small amount of water/glycerin solution. 
Slides were scanned with a Zeiss Universal compound microscope for polarized light at $200 \times$, and identifications were made at $400 \times$ using standard methods. Digital images were captured at 800× magnification using a Micropublisher 3.3 camera and software.

\section{B.4 RESULT AND DISCUSSION}

The following table lists the burned rocks that were analyzed for this study (Table B-1). Unfortunately, no starchy plant remains were recovered from any of the samples.
Burned rocks typically yield small numbers of starch grains, and are selected for study more for their ability to identify cooking activities at a site than for mass recovery of plant remains. While the results from this study are certainly not what one hopes for, it should be noted that the absence of starchy remains from these burned rocks does not preclude the recovery of residues from other classes of artifacts from the same site, or from burned rocks that occurred in different features. Further analysis of ground stone or flaked tools, for example, could yield more data.

Table B-1. List of Burned Rock Samples Investigated

\begin{tabular}{|c|c|c|c|c|c|}
\hline $\begin{array}{c}\text { Test Unit } \\
\text { No. }\end{array}$ & $\begin{array}{c}\text { Depth } \\
(\mathbf{c m b s})\end{array}$ & PNUM & $\begin{array}{c}\text { Weight } \\
(\mathbf{g})\end{array}$ & Material & Comments \\
\hline 1 & $140-150$ & $68-1$ & 54 & Chert & angled interior \\
\hline 3 & $80-90$ & $36-1$ & 23 & $?$ & very hackled \\
\hline 5 & $80-90$ & $84-1$ & 32.5 & $?$ & partially hackled edge \\
\hline 5 & $150-160$ & $132-1$ & 75 & $?$ Quartzite & outside and inside hackled \\
\hline 6 & $110-120$ & $97-1$ & 24 & Chert & very jagged \\
\hline 6 & $140-150$ & $118-1$ & 49 & Chert & Cobble, 1 end hackled \\
\hline 8 & 132 & $104-1$ & 258 & Chert & Spall \\
\hline 9 & $80-90$ & $76-1$ & 331 & ?Quartzite & Cobble with possible worked end \\
\hline 9 & $110-120$ & $89-1$ & 18 & Quartzite & Nearly intact \\
\hline BT-7 & $100-110$ & $117-1$ & 109 & Chert & \\
\hline
\end{tabular}




\section{B.5 REFERENCES CITED}

Atchison, J. and R. Fullagar,

1998 Starch residues on pounding implements from Jinmium rock-shelter. In: R. Fullagar (Ed.), A Closer Look: Recent Studies of Australian Stone Tools, Sydney University Archaeological Methods Series 6, Archaeological Computing Laboratory, School of Archaeology, University of Sydney, Sydney.

Babot, M. del Pilar

2003 Starch grain damage as an indicator of food processing. Pp. 69-81. In: D. M. Hart, L. A. Wallis (Eds.), Phytolith and Starch Research in the Australian-Pacific-Asian Regions: The State of the Art. Papers from a conference held at the ANU, August 2001, Canberra, Australia. Pandanus Books.

Babot, M. del Pilar and M. C. Apella

2003 Maize and bone: residues of grinding in northwestern Argentina. Archaeometry 45:121-132.

Barton, H., R. Torrence, and R. Fullagar.

1998 Clues to Stone Tool Function Reexamined: Comparing Starch Grain Frequencies on Used and Unused Obsidian Artefacts. Journal of Archaeological Science 25:1231-1238.

Briuer, F. L.

1976 New Clues to Stone Tool Function: Plant and Animal Residues. American Antiquity 41:478-484.

Bryant, V. M.

2003 Invisible clues to new world plant domestication. Science 299:1029-1030.

Coil, J., M. A. Korstanje, S. Archer, and C. A. Hastorf

2003 Laboratory goals and considerations for multiple microfossil extraction in archaeology. Journal of Archaeological Science 30:991-1008.
Crawford, G. W. and D. G. Smith

2003 Paleoethnobotany in the Northeast. In People and Plants in Ancient Eastern North America, edited by P. E. Minnis, pp. 172-257. Smithsonian Books, Washington D C.

Denniston, R. H.

1904 The Growth and Organization of the Starch Grain. Ph.D. dissertation. University of Wisconsin, Madison.

Fullagar, R., T. Loy, and S. Cox,

1998 Starch grains, sediments and stone tool function: evidence from Bitokara, Papua New Guinea. Pp. 49-58. In: R. Fullagar (ed). A Closer Look: Recent Australian Studies of Stone Tools. Archaeological Computing Laboratory, University of Sydney.

Green W. and C. Tolmie

2004 Analysis of Plant Remains from Blood Run. Plains Anthropologist 49:525-542.

Hall, J., S. Higgins, and R. Fullagar

1989 Plant Residues on Stone Tools. Tempus 1:136-155.

Haslam, M.

2003 Evidence for maize processing on 2000 year old obsidian artefacts from Copán, Honduras. pp. 153-161. In: D. M. Hart, L. A. Wallis (Eds.), Phytolith and Starch Research in the Australian-Pacific-Asian Regions: The State of the Art. Papers from a conference held at the ANU, August 2001, Canberra, Australia. Pandanus Books.

2004 The decomposition of starch grains in soils: implications for archaeological residue analyses. Journal of Archaeological Science 31:1715-1734.

Henry A. G., Hudson H. F. and D. R. Piperno

2009 Changes in starch grain morphologies from cooking. Journal of Archaeological Science 36:915-922. 
Iriarté, J., I. Holst, O. Marozzi, C. Listopad, E. Alonso, A. Rinderknecht, and J. Montaña

2004 Evidence for cultivar adoption and emerging complexity during the midHolocene in the La Plata basin. Nature 432:614-617.

Loendorf, L. L.

1985 A Possible Explanation for the Association between Wild Rye Grass (Elymus spp.) and Formerly Occupied Cave Sites in the Pryor Mountains, Montana. Plains Anthropologist 30:137-144.

Loy, T. H.

1994 Methods in the Analysis of Starch Residues on Prehistoric Stone Tools. Pp. 86-113. In: J. G. Hather (Ed.). Tropical Archaeobotany: Applications and New Developments. Routledge.

Loy, T. H., M. Spriggs, and S. Wickler

1992 Direct evidence for human use of plants 28,000 years ago: starch residues on stone artifacts from the northern Solomon Islands. Antiquity 66:898-912.

MacMasters, M. M.

1964 Microscopic Techniques for Determining Starch Granule Properties. Pp. 233-240. In: R. L. Whistler (Ed.), Methods in Carbohydrate Chemistry. Academic Press.

Pearsall, D. M., K. Chandler-Ezell, and J. A. Zeidler

2004 Maize in ancient Ecuador: results of residue analysis of stone tools from the Real Alto site. Journal of Archaeological Science 31:423-442.

Perry, L.

2001 Prehispanic subsistence in the middle Orinoco basin: starch analyses yield new evidence. Doctoral dissertation, Southern Illinois University Carbondale, Illinois.

2002 Starch analyses indicate multiple functions of quartz "manioc" grater flakes from the Orinoco basin, Venezuela. Interciencia 27(11):635-639.
2004 Starch analyses reveal the relationship between tool type and function: an example from the Orinoco valley of Venezuela. Journal of Archaeological Science 31(8):1069-1081.

2005 Reassessing the traditional interpretation of "manioc" artifacts in the Orinoco valley of Venezuela. Latin American Antiquity.

2007 Starch grains, preservation biases, and plant histories. In Rethinking Agriculture: Archaeological and Ethnographic Perspectives, edited by T. Denham, L. Vrydaghs and J. Iriarté. One World Archaeology, Left Coast Press.

2010 Starch Analyses from the BLM Landis Property. In Landis Property: Data Recovery at Three Prehistoric Sites (41PT185, 41PT186, and 41PT245) in Potter County, Texas, edited by J. Michael Quigg, Charles D. Frederick, Paul M. Matchen, and Kendra G. DeBois, pp. 767785. TRC Technical Report 150832, TRC Environmental Corporation, Austin.

Perry, L. and J. M. Quigg

2011a Starch remains and stone boiling in the Texas panhandle part 1: The Pipeline, Corral, and Pavilion sites. Plains Anthropologist 56:95-108.

2011b Starch remains and stone boiling in the Texas panhandle part 2: Identifying wildrye (Elymus spp.). Plains Anthropologist 56:109-120.

Perry, L., D. Sandweiss, D. Piperno, K. Rademaker, M. Malpass, A. Umire, and P. de la Vera.

2006 Early Maize Agriculture and Interzonal Interaction in Southern Peru. Nature 440:76-79.

Perry, L., R. Dickau, S. Zarrillo, I. Holst, D. Pearsall, D. Piperno, M. Berman, R. Cooke, K. Rademaker, A. Ranere, J. Raymond, D. Sandweiss, F. Scaramelli, K. Tarble, and J. Zeidler.

2007 Starch fossils and the domestication and dispersal of chili peppers (Capsicum spp. L.) in the Americas. Science 315:986-988. 
With accompanying Perspective, Knapp, S . Some Like it Hot. Science 315:946-947.

Piperno, D. R. and I. Holst

1998 The presence of starch grains on prehistoric stone tools from the humid Neotropics: indications of early tuber use and agriculture in Panama. Journal of Archaeological Science 25:765-776.

Piperno, D. R., A. J. Ranere, I. Holst, and P. Hansell 2000 Starch grains reveal early root crop horticulture in the Panamanian tropical forest. Nature 407:894-897.
Ranere, A. J.

1975 Toolmaking and tool use among the preceramic peoples of Panama, pp. 173210. In: E. H. Swanson (Ed.) Lithic Technology. Mouton.

Reichert, E. T.

1913 The Differentiation and Specificity of Starches in Relation to Genera, Species, Etc. In two parts. Carnegie Institution of Washington. 


\section{APPENDIX C: ARTIFACT FREQUENCY DATA}

Prepared for:

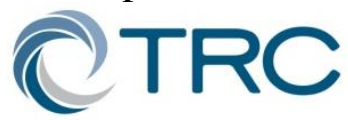

TRC Environmental Corporation

505 East Huntland Drive, Suite 250

Austin, Texas 78752

Prepared by:

Trisha-Ann P. Gonzales

2012 
This page intentionally left blank, 


\section{ARTIFACT FREQUENCY DATA}

Table C-1. Test Units 1 and 2

\begin{tabular}{|c|c|c|c|c|c|c|c|}
\hline \multicolumn{7}{|c|}{ TRC ENVIRONMENTAL CULTURAL RESOURCES PROGRAM } \\
\hline \multicolumn{7}{|c|}{ TAN GARIEL ARTIFACT FREQUENCY DISTRIBUTION } \\
\hline Site Number/Name: 41MM382 Barrett Site TRC Project \# 192919 \\
\hline Excavator: Travis Karlsgaard \\
\hline
\end{tabular}

BR=Burned Rock, LL=Lithic Debitage, LT=Lithic Tool, MS=Mussel Shell, BA=Bone 
Table C-2. Test Units 4 and 5

\begin{tabular}{|c|c|c|c|c|c|c|c|c|c|c|c|}
\hline \multicolumn{12}{|c|}{ TRC ENVIRONMENTAL CULTURAL RESOURCES PROGRAM } \\
\hline \multicolumn{12}{|c|}{ SAN GABRIEL ARTIFACT FREQUENCY DISTRIBUTION } \\
\hline \multicolumn{6}{|c|}{ Site Number/Name: 41MM382 Barrett Site } & \multicolumn{2}{|c|}{ TRC Project \# 192919} & \multicolumn{4}{|c|}{ Date: May 2012} \\
\hline \multicolumn{6}{|c|}{ Excavator: Shannon Gray } & \multicolumn{6}{|c|}{ Excavator: Heath Bentley } \\
\hline \multirow{2}{*}{ CMBS } & \multicolumn{3}{|c|}{ Test Unit \# . } & \multicolumn{2}{|l|}{4} & \multirow{2}{*}{ CMBS } & \multicolumn{3}{|c|}{ Test Unit \# } & \multicolumn{2}{|c|}{5} \\
\hline & BA & BR & $\mathbf{L L}$ & LT & MS & & BA & BR & $\mathbf{L L}$ & LT & MS \\
\hline 0-10 & 0 & 0 & 0 & 0 & 0 & $0-10$ & \multirow{2}{*}{\multicolumn{5}{|c|}{ Not Screened }} \\
\hline 10-20 & 0 & 2 & 0 & 0 & 0 & $10-20$ & & & & & \\
\hline $20-30$ & 0 & 0 & 0 & 0 & 0 & $20-30$ & \multirow{2}{*}{\multicolumn{5}{|c|}{ Not Screened }} \\
\hline $30-40$ & 0 & 2 & 0 & 0 & 0 & $30-40$ & & & & & \\
\hline $40-50$ & 0 & 4 & 0 & 0 & 0 & $40-50$ & \multicolumn{5}{|c|}{ Not Screened } \\
\hline $50-60$ & 0 & 1 & 4 & 0 & 0 & $50-60$ & 0 & 0 & 2 & 0 & 1 \\
\hline $60-70$ & & & & & & $60-70$ & 0 & 4 & 2 & 0 & 1 \\
\hline $70-80$ & 0 & 2 & 4 & 0 & 0 & $70-80$ & 0 & 4 & 3 & 0 & 2 \\
\hline $80-90$ & 0 & 0 & 5 & 0 & 5 & $80-90$ & 0 & 13 & 4 & 0 & 1 \\
\hline $90-100$ & 0 & 1 & 4 & 0 & 1 & $90-100$ & 0 & 6 & 0 & 0 & 1 \\
\hline $100-110$ & 0 & 3 & 8 & 0 & 6 & $100-110$ & 0 & 5 & 2 & 0 & 2 \\
\hline $110-120$ & 0 & 8 & 20 & 0 & 13 & $110-120$ & 0 & 13 & 0 & 0 & 3 \\
\hline $120-130$ & 0 & 6 & 11 & 0 & 2 & $120-130$ & 0 & 7 & 2 & 0 & 1 \\
\hline $130-140$ & 0 & 5 & 6 & 0 & 5 & 130-140 & 0 & 25 & 4 & 0 & 2 \\
\hline $140-150$ & 1 & 4 & 14 & 0 & 7 & $140-150$ & 0 & 20 & 13 & 0 & 10 \\
\hline $150-160$ & \multirow{2}{*}{\multicolumn{5}{|c|}{ Complete }} & $150-160$ & 0 & 6 & 3 & 0 & 1 \\
\hline $160-170$ & & & & & & $160-170$ & \multicolumn{5}{|c|}{ Complete } \\
\hline TOTAL & 1 & 38 & 76 & 0 & 39 & TOTAL & 0 & 103 & 35 & 0 & 25 \\
\hline
\end{tabular}

BR=Burned Rock, LL=Lithic Debitage, LT=Lithic Tool, MS=Mussel Shell, BA=Bone 
Table C-3. Test Units 6 and 7

\begin{tabular}{|c|c|c|c|c|c|c|c|c|c|c|c|}
\hline \multicolumn{12}{|c|}{ TRC ENVIRONMENTAL CULTURAL RESOURCES PROGRAM } \\
\hline \multicolumn{12}{|c|}{ SAN GABRIEL ARTIFACT FREQUENCY DISTRIBUTION } \\
\hline \multicolumn{6}{|c|}{ Site Number/Name: 41MM382 Barrett Site } & Project \# & 919 & \multicolumn{4}{|c|}{ Date: May 2012} \\
\hline \multicolumn{6}{|c|}{ Excavator: Trisha Gonzales } & \multicolumn{6}{|c|}{ Excavator: Heath Bentley } \\
\hline \multirow{2}{*}{ CMBS } & \multicolumn{4}{|c|}{ Test Unit \# 6} & & \multirow{2}{*}{ CMBS } & \multicolumn{4}{|c|}{ Test Unit \# 7} & \\
\hline & BA & $\mathbf{B R}$ & $\mathbf{L} \mathbf{L}$ & LT & MS & & BA & $\mathbf{B R}$ & $\mathbf{L} \mathbf{L}$ & LT & MS \\
\hline 0-10 & \multirow{2}{*}{\multicolumn{5}{|c|}{ Not Screened }} & 0-10 & \multirow{2}{*}{\multicolumn{5}{|c|}{ Not Screened }} \\
\hline $10-20$ & & & & & & $10-20$ & & & & & \\
\hline 20-30 & \multirow{2}{*}{\multicolumn{5}{|c|}{ Not Screened }} & $20-30$ & \multirow{2}{*}{\multicolumn{5}{|c|}{ Not Screened }} \\
\hline $30-40$ & & & & & & $30-40$ & & & & & \\
\hline 40-50 & \multicolumn{5}{|c|}{ Not Screened } & 40-50 & \multicolumn{5}{|c|}{ Not Screened } \\
\hline $50-60$ & 0 & 2 & 2 & 1 & 0 & $50-60$ & 0 & 0 & 3 & 1 & 0 \\
\hline $60-70$ & 0 & 2 & 1 & 0 & 3 & $60-70$ & 0 & 0 & 3 & 0 & 1 \\
\hline $70-80$ & 1 & 15 & 0 & 0 & 5 & $70-80$ & 0 & 1 & 4 & 0 & 1 \\
\hline $80-90$ & 0 & 10 & 3 & 0 & 8 & $80-90$ & 0 & 14 & 10 & 0 & 2 \\
\hline $90-100$ & 1 & 7 & 14 & 0 & 4 & $90-100$ & 0 & 5 & 2 & 0 & 3 \\
\hline $100-110$ & 0 & 9 & 20 & 0 & 7 & $100-110$ & 0 & 22 & 12 & 0 & 10 \\
\hline $110-120$ & 0 & 31 & 20 & 0 & 7 & $110-120$ & 1 & 4 & 8 & 0 & 2 \\
\hline $120-130$ & 1 & 4 & 13 & 0 & 1 & 120-130 & 0 & 8 & 6 & 0 & 9 \\
\hline 130-140 & 0 & 26 & 51 & 0 & 7 & $130-140$ & 1 & 7 & 0 & 0 & 6 \\
\hline $140-150$ & 0 & 46 & 73 & 0 & 16 & $140-150$ & 1 & 10 & 4 & 0 & 3 \\
\hline $150-160$ & 0 & 19 & 31 & 0 & 7 & $150-160$ & \multirow{2}{*}{\multicolumn{5}{|c|}{ Complete }} \\
\hline $160-170$ & \multicolumn{5}{|c|}{ Complete } & $160-170$ & & & & & \\
\hline TOTAL & 3 & 171 & 228 & 1 & 65 & TOTAL & 3 & 71 & 52 & 1 & 37 \\
\hline
\end{tabular}

BR=Burned Rock, LL=Lithic Debitage, LT=Lithic Tool, MS=Mussel Shell, BA=Bone 
Table C-4. Test Units 8 and 9

\begin{tabular}{|c|c|c|c|c|c|c|c|c|c|c|c|}
\hline \multicolumn{12}{|c|}{ TRC ENVIRONMENTAL CULTURAL RESOURCES PROGRAM } \\
\hline \multicolumn{12}{|c|}{ SAN GABRIEL ARTIFACT FREQUENCY DISTRIBUTION } \\
\hline \multicolumn{5}{|c|}{ Site Number/Name: 41MM382 Barrett Site } & \multicolumn{3}{|c|}{ TRC Project \# 192919} & \multicolumn{4}{|c|}{ Date: May 2012} \\
\hline \multicolumn{6}{|c|}{ Excavator: Shannon Gray } & \multicolumn{6}{|c|}{ Excavator: Heath Bentley } \\
\hline \multirow{2}{*}{ CMBS } & \multicolumn{4}{|c|}{ Test Unit \# _ 8} & & \multirow{2}{*}{ CMBS } & \multicolumn{3}{|c|}{ Test Unit \# } & 9 & \\
\hline & BA & BR & $\mathbf{L L}$ & $\mathbf{L} \mathbf{T}$ & MS & & BA & BR & $\mathbf{L L}$ & $\mathbf{L} \mathbf{T}$ & MS \\
\hline 0-10 & \multirow{2}{*}{\multicolumn{5}{|c|}{ Not Screened }} & 0-10 & \multirow{2}{*}{\multicolumn{5}{|c|}{ Not Screened }} \\
\hline 10-20 & & & & & & 10-20 & & & & & \\
\hline 20-30 & \multirow{2}{*}{\multicolumn{5}{|c|}{ Not Screened }} & 20-30 & \multirow{2}{*}{\multicolumn{5}{|c|}{ Not Screened }} \\
\hline $30-40$ & & & & & & $30-40$ & & & & & \\
\hline 40-50 & \multicolumn{5}{|c|}{ Not Screened } & $40-50$ & \multicolumn{5}{|c|}{ Not Screened } \\
\hline $50-60$ & 0 & 6 & 2 & 0 & 0 & $50-60$ & 0 & 2 & 5 & 0 & 2 \\
\hline $60-70$ & 0 & 1 & 0 & 0 & 1 & $60-70$ & 0 & 2 & 7 & 0 & 1 \\
\hline $70-80$ & 0 & 11 & 0 & 0 & 1 & 70-80 & 0 & 16 & 18 & 2 & 1 \\
\hline $80-90$ & 0 & 6 & 4 & 0 & 1 & $80-90$ & 0 & 34 & 43 & 1 & 17 \\
\hline $90-100$ & 0 & 31 & 22 & 0 & 5 & $90-100$ & 0 & 23 & 20 & 0 & 9 \\
\hline $100-110$ & 0 & 45 & 35 & 0 & 8 & 100-110 & 1 & 59 & 90 & 1 & 0 \\
\hline $110-120$ & 0 & 28 & 43 & 0 & 8 & $110-120$ & 16 & 112 & 361 & 4 & 6 \\
\hline $120-130$ & 0 & 15 & 20 & 0 & 3 & $120-130$ & 1 & 33 & 131 & 1 & 9 \\
\hline $130-140$ & 0 & 5 & 10 & 0 & 12 & $130-140$ & 0 & 16 & 21 & 0 & 1 \\
\hline $140-150$ & 0 & 0 & 0 & 1 & 2 & $140-150$ & 0 & 6 & 15 & 0 & 1 \\
\hline $150-160$ & \multirow{2}{*}{\multicolumn{5}{|c|}{ Complete }} & $150-160$ & \multirow{2}{*}{\multicolumn{5}{|c|}{ Complete }} \\
\hline $160-170$ & & & & & & $160-170$ & & & & & \\
\hline TOTAL & 0 & 148 & 136 & 1 & 41 & TOTAL & 18 & 303 & 711 & 9 & 47 \\
\hline
\end{tabular}

BR=Burned Rock, LL=Lithic Debitage, LT=Lithic Tool, MS=Mussel Shell, BA=Bone 


\section{APPENDIX D: \\ GEOLOGICAL DESCRIPTIONS}

Prepared for:

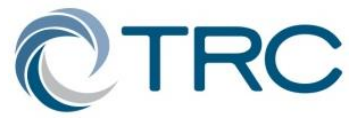

TRC Environmental Corporation

505 East Huntland Drive, Suite 250

Austin, Texas 78752

Prepared by:

Charles D. Frederick, Ph.D.

2901 Highway 1496

Dublin, TX 76446 
This page intentionally left blank. 


\section{GEOLOGICAL DESCRIPTIONS}

Charles D. Frederick, Ph.D.

Table D-1. Trench 1, Test Unit 1

\begin{tabular}{|l|l|l|l|}
\hline Zone & $\begin{array}{c}\text { Depth } \\
(\mathbf{c m})\end{array}$ & Horizon & \\
\hline 1 & $0-28$ & A & $\begin{array}{l}\text { Very dark gray (10YR 3/1, m) clay, very friable, moderate medium to fine } \\
\text { subangular blocky structure, gradual smooth boundary, strongly } \\
\text { effervescent; Upper Alluvium. }\end{array}$ \\
\hline 2 & $28-65$ & AB & $\begin{array}{l}\text { Dark grayish brown (10YR 4/2, m) silty clay, firm, weak to moderate } \\
\text { medium prismatic structure parting to moderate to strong fine subangular } \\
\text { blocky structure, clear smooth boundary, slightly effervescent, few snail } \\
\text { shell fragments, approximately 1-3\% calcium carbonate filaments; Upper } \\
\text { Alluvium. }\end{array}$ \\
\hline $2 \mathrm{a}$ & $65-105$ & ABk & $\begin{array}{l}\text { Dark grayish brown (10YR 4/2, m) silty clay, firm, weak to moderate } \\
\text { medium prismatic structure parting to moderate to strong fine subangular } \\
\text { blocky structure, clear smooth boundary, slightly effervescent, few snail } \\
\text { shell fragments, approximately 1-3\% calcium carbonate filaments; Upper } \\
\text { Alluvium. }\end{array}$ \\
\hline 3 & $\begin{array}{l}105- \\
135\end{array}$ & $2 \mathrm{Akb}$ & $\begin{array}{l}\text { Very dark gray - very dark grayish brown (10YR 3/1.5, m) clay, firm, weak } \\
\text { to moderate medium prismatic structure parting to strong medium to coarse } \\
\text { angular blocky structure, clear smooth boundary, slightly effervescent, } \\
\text { common (3-5\%) calcium carbonate filaments; Lower Alluvium. }\end{array}$ \\
\hline 160 & $2 \mathrm{ABk}$ & $\begin{array}{l}\text { Very dark gray-dark gray (10YR 3.5/1, m) silty clay, friable, weak to } \\
\text { moderate medium to coarse prismatic structure, slightly effervescent, few } \\
\text { snail shell fragments, 1-3\% calcium carbonate filaments; Lower Alluvium. }\end{array}$ \\
\hline
\end{tabular}


Table D-2. Trench 2, Test Unit 2

\begin{tabular}{|l|l|l|l|}
\hline Zone & $\begin{array}{c}\text { Depth } \\
(\mathbf{c m})\end{array}$ & Horizon & \\
\hline 1 & $0-36$ & A & $\begin{array}{l}\text { Very dark gray (10YR 3/1, m) clay, friable, strong ,medium to fine } \\
\text { subangular blocky structure, clear smooth boundary, violently effervescent; } \\
\text { Upper Alluvium. }\end{array}$ \\
\hline 2 & $36-60$ & AB & $\begin{array}{l}\text { Very dark gray - very dark grayish brown (10YR 3/1.5, m) silty clay, } \\
\text { friable, moderate medium to coarse subangular blocky structure, gradual } \\
\text { wavy boundary, strongly effervescent; Upper Alluvium. }\end{array}$ \\
\hline 3 & $\begin{array}{l}102- \\
130\end{array}$ & $2 \mathrm{Akb}$ & $\begin{array}{l}\text { Very dark grayish brown (10YR 3/2, m) silty clay, friable, moderate } \\
\text { medium to coarse subangular blocky structure, clear smooth boundary, } \\
\text { strongly effervescent, 5-7\% calcium carbonate filaments; Upper Alluvium. } \\
\text { Black-very dark gray (10YR 2.5/1, m) slay to silty clay, friable to firm, } \\
\text { moderate to strong medium to coarse prismatic structure parting to strong } \\
\text { medium angular blocky structure, gradual smooth boundary, strongly } \\
\text { effervescent, few snail shell fragments, strongly effervescent, many (7- } \\
\text { 10\%) calcium carbonate filaments; Lower Alluvium. }\end{array}$ \\
\hline 4 & $\begin{array}{l}130- \\
150\end{array}$ & $2 \mathrm{ABk}$ & $\begin{array}{l}\text { Very dark grayish brown (10YR 3/2, m) silty clay, friable, weak to } \\
\text { moderate medium to coarse prismatic structure parting to moderate fine } \\
\text { angular blocky structure, common (5-7\%) calcium carbonate filaments, few } \\
\text { pressure faces, few snail shell fragments; Lower Alluvium. }\end{array}$ \\
\hline
\end{tabular}


Table D-3. Trench 3

\begin{tabular}{|c|c|c|c|}
\hline Zone & $\begin{array}{c}\text { Depth } \\
\text { (cm) }\end{array}$ & Horizon & Description \\
\hline 1 & -- & Ap & $\begin{array}{l}\text { Black to very dark gray }(10 \mathrm{YR} 3 / 1.5, \mathrm{~m}) \text { clay, friable, moderate fine } \\
\text { subangular blocky structure, abrupt smooth boundary, strongly effervescent, } \\
\text { Road Embankment Fill. }\end{array}$ \\
\hline 2 & -- & Ap & $\begin{array}{l}\text { Very dark gray to dark grayish brown (10YR } 3 / 1-4 / 2, \mathrm{~m}) \text { silty clay, friable, } \\
\text { moderate medium to fine subangular blocky structure, abrupt smooth } \\
\text { boundary, strongly effervescent, Road Embankment Fill. }\end{array}$ \\
\hline $2 \mathrm{~A}$ & -- & Ap & $\begin{array}{l}\text { Very dark gray }(10 \mathrm{YR} 3 / 1, \mathrm{~m}) \text { sandy clay, friable, weak to moderate medium } \\
\text { to fine subangular blocky structure, abrupt smooth boundary, strongly } \\
\text { effervescent, thin sand beds at the base of Zone } 2 \text {, not very discrete; Road } \\
\text { Embankment Fill. }\end{array}$ \\
\hline 3 & -- & $\mathrm{Ap}$ & $\begin{array}{l}\text { Very dark gray }(10 \mathrm{YR} 3 / 1, \mathrm{~m}) \text { clay, very hard, strong very fine platy structure, } \\
\text { abrupt smooth boundary, strongly effervescent, many }(5-15 \%) \text { light gray } \\
(10 \mathrm{YR} 7 / 2) \text { coarse }(2-15 \mathrm{~mm}) \text { limestone fragments, compacted by heavy } \\
\text { equipment Road Embankment Fill or Upper Alluvium. }\end{array}$ \\
\hline 4 & -- & $2 \mathrm{~A}$ & $\begin{array}{l}\text { Black to very dark gray }(10 \mathrm{YR} 2 / 1 \text { to } 3 / 1, \mathrm{~m}) \text { clay, friable, strong medium to } \\
\text { fine subangular blocky structure, diffuse smooth boundary, strongly } \\
\text { effervescent; Upper Alluvium. }\end{array}$ \\
\hline 5 & -- & $2 \mathrm{AB}$ & $\begin{array}{l}\text { Very dark grayish brown to dark yellowish-brown (10YR } 3 / 2 \text { to } 4 / 2 \text {, m) silty } \\
\text { clay, very firm, weak to moderate medium prismatic structure parting to } \\
\text { strong fine subangular blocky structure, gradual smooth boundary, strongly } \\
\text { effervescent; Upper Alluvium. }\end{array}$ \\
\hline 6 & -- & $2 \mathrm{Bw}$ & $\begin{array}{l}\text { Dark gray to dark grayish brown (10YR } 4 / 1.5, \mathrm{~m} ; 10 \mathrm{YR} 4 / 2, \mathrm{~d}) \text {, silty clay, } \\
\text { very firm, strong medium to coarse prismatic structure parting to strong } \\
\text { medium to coarse angular blocky structure, clear smooth boundary, strongly } \\
\text { effervescent; Upper Alluvium? }\end{array}$ \\
\hline 7 & -- & $3 \mathrm{Akb}$ & $\begin{array}{l}\text { Dark grayish brown }(10 \mathrm{YR} 4 / 2, \mathrm{~m} ; 10 \mathrm{YR} 4 / 2, \mathrm{~d}) \text { clay, very firm, strong } \\
\text { coarse to very coarse prismatic structure, strongly effervescent, few }(1-2 \%) \\
\text { calcium carbonate filaments; Lower Alluvium. }\end{array}$ \\
\hline
\end{tabular}

Comments: See Figure 5-3, lower panel for the relative depths of each zone. 
Table D-4. $\quad$ TxDOT Trench 7

\begin{tabular}{|l|l|l|l|}
\hline Zone & $\begin{array}{c}\text { Depth } \\
\mathbf{( c m})\end{array}$ & Horizon & \\
\hline 1 & $0-52$ & A & $\begin{array}{l}\text { Black (10YR 2/1, m) to very dark gray (10YR 3/1, m) clay, firm, moderate } \\
\text { to strong medium to coarse subangular blocky structure, gradual smooth } \\
\text { boundary, strongly effervescent, few 1-3 mm snail shell fragments; Upper } \\
\text { Alluvium. }\end{array}$ \\
\hline 2 & $\begin{array}{l}52- \\
111\end{array}$ & AB & $\begin{array}{l}\text { Very dark grayish brown (10YR 3/2, m) silty clay, friable, weak coarse to } \\
\text { medium subangular blocky structure, clear smooth boundary, strongly } \\
\text { effervescent; Upper Alluvium. }\end{array}$ \\
\hline 3 & $111-$ & Abk & $\begin{array}{l}\text { Very dark brown - very dark grayish brown (10YR 2.5/2, m) silty clay to } \\
\text { clay, firm, strong medium to coarse prismatic structure parting to strong } \\
\text { medium to coarse angular blocky structure, clear smooth boundary, strongly } \\
\text { effervescent, few (1-3\%) calcium carbonate filaments, few 1-3 mm shell } \\
\text { fragments; Lower Alluvium. }\end{array}$ \\
\hline 5 & $\begin{array}{l}147 \\
166-\end{array}$ & Bk & $\begin{array}{l}\text { ABk } \\
\text { Brown (10YR 4.5/3, m) clay, firm, weak to moderate coarse prismatic } \\
\text { structure, slightly to moderately effervescent, few to common (3-7\%) } \\
\text { calcium carbonate filaments, few snail shell fragments; Lower Alluvium. }\end{array}$ \\
\hline $\begin{array}{l}\text { Brown (10YR 4/3, m) clay, firm, weak to moderate medium to coarse } \\
\text { prismatic structure, clear smooth boundary, strongly effervescent, few (3\%) } \\
\text { calcium carbonate filaments; Lower Alluvium. }\end{array}$
\end{tabular}

